Western Washington University Western CEDAR

\title{
Studies on Mongolia: Proceedings of the First North American Conference on Mongolian Studies
}

Henry G. Schwarz

Western Washington University, schwarz@wwu.edu

Follow this and additional works at: https://cedar.wwu.edu/easpress

Part of the East Asian Languages and Societies Commons

\section{Recommended Citation}

Schwarz, Henry G., "Studies on Mongolia: Proceedings of the First North American Conference on Mongolian Studies" (1979). East Asian Studies Press. 5.

https://cedar.wwu.edu/easpress/5

This Book is brought to you for free and open access by the Books and Monographs at Western CEDAR. It has been accepted for inclusion in East Asian Studies Press by an authorized administrator of Western CEDAR. For more information, please contact westerncedar@wwu.edu. 


\section{STUDIES ON MONGOLIA}

Proceedings of the First North American Conference on Mongolian Studies 
Center for East Asian Studies, Western Washington University

Studies on East Asia, Volume Thirteen:

STUDIES ON MONGOLIA: PROCEEDINGS OF THE FIRST NORTH AMERICAN CONFERENCE ON MONGOLIAN STUDIES, edited by Henry G. Schwarz

The Center for East Asian Studies publishes scholarly works on topics relating to China, Japan, Korea, and Mongolia.

\section{Editor:}

Professor Henry G. Schwarz 


\title{
STUDIES ON MONGOLIA
}

Proceedings of the First North American Conference on Mongolian Studies

\author{
HENRY G. SCHWARZ \\ Editor
}

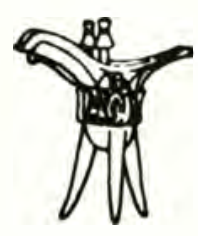

WESTERN WASHINGTON UNIVERSITY 
Copyright 1979

by

CENTER FOR EAST ASIAN STUDIES

Western Washington University

Bellingham, Washington 98225

All rights reserved. No part of this publication may be reproduced or transmitted in any form or by any means, electronic or mechanical, including photocopy, recording, or any information storage or retrieval system, without permission in writing from the publisher.

Library of Congress Cataloging in Publication Data

North American Conference on Mongolian Studies, lst,

Bellingham, Wash., 1978.

Studies on Mongolia.

(Studies on East Asia ; v. 13)

1. Mongolia--Congresses. I. Schwarz, Henry G., 1928- II. Western Washington University. Center for East Asian Studies. III. Title. IV. Series. DS793.M7N67 1978 $\quad 951 ' .7 \quad 79-4517$ ISBN $0-914584-13-8$

The preparation of this volume has been aided by a grant from the National Endowment for the Humanities. 


\section{PREFACE}

It is my pleasure to present to Mongolists and other interested readers the proceedings of the first North American Conference on Mongolian Studies, held in Bellingham on November 25-26, 1978.

The idea for such a conference occurred to me about two years ago. As I recall, it was not some specific event that prompted my decision to organize the conference; rather, it probably was disappointment, slowly accumulating over the years, at seeing North American studies on Mongolia lagging behind those on China, Japan, and Korea in this respect. True, larger conferences, like those sponsored by the Association for Asian Studies and the American Oriental Society, have often included panels dealing at least partially with Mongolia, and the Mongolia Society has done a signal service by holding its annual meetings in conjunction with those conferences. Yet I felt that the time had come to give Mongolists their own conference. The experiences of our colleagues in Chinese, Japanese, and Korean studies clearly pointed out the main advantage of holding a conference devoted to a single country or culture. It could provide a setting in which Mongolists felt "at home," undisturbed by the clamor of the bazaar-like atmosphere often prevailing at the larger all-Asian conferences.

With this goal in mind, I started my preparations on May I of last year by sending out a first call for papers. The response was much greater than I had expected and dashed my rather modest hopes of having one day of sessions. The result was a busy schedule from $8: 30 \mathrm{a} . \mathrm{m}$. to $8: 30 \mathrm{p} . \mathrm{m}$. on Saturday with only two short breaks, and from 9:00 a.m. to $1 \mathrm{p} . \mathrm{m}$. on Sunday without any breaks. An equally pleasant surprise was the great distances traveled by many participants, coming as they did from Southern California and New England, the Middle Atlantic states and the Canadian prairies, the Rocky Mountains and the Midwest. Professor Kimura hastened from Tokyo on his first journey to North America, and Mr. Dashtseren, the Mongolian ambassador to the United Nations, was all set to come but pressing business forced him to cancel at the last moment.

The verdict on this conference was passed in the concluding session in the form of two resolutions. One called for making such a conference an annual event. I stressed the importance of moving future conferences around the United States and Canada, and the idea was accept ${ }^{-}$. A committee, composed of Professors Larry Clark, Paul Hyer, Keith Scott and myself, was elected and given the task of selecting the site of the second conference, scheduled for this year. The other resolution instructed me to edit and publish the conference papers. The result is this book.

While I planned and hosted the first conference, its success could not have been achieved without the help of many individuals and organizations. My thanks go to all participants for their fine scholarly papers, lively discussions, and enthusiasm. Professors Samuel E. Martin of Yale University, John Masson Smith, Jr. of the University of California at Berkeley, and John Street 
of the University of Wisconsin gave their wholehearted support to the conference even though they were unable to attend. The National Endowment for the Humanities granted timely and generous financial assistance. Also supportive were grants from the Mongolia Society and from Dean James W. Davis of the College of Arts and Sciences at Western Washington University. The Canada-

Mongolia Society cooperated from the very start and repeatedly advertised the conference throughout Canada. Many of the technical chores were competently handled by Joseph Cucco, Bruce Ream, Linda Kaplowitz, Mary Crompton, Richard Chesmore, and Sharon Edinger. Finally, Mrs. Florence Preder once again produced a meticulous manuscript. To all these individuals and organizations I wish to extend my gratitude for their trust, support, and assistance.

Henry G. Schwarz 
CONTENTS

Preface, by Henry G. Schwarz . . . . . . . . . . . . . . . . .

Language and Culture

Robert I. Binnick, Past and Perfect in Modern Mongolian. . . . . . . . . 1

Larry V. Clark, A Problem in Buryat Historical Linguistics . . . . . . . 14

Hisao Kimura, The Activities of the MPR State Committee for Terminology: Basic Principles in Formulating

New Vocabulary . . . . . . . . . . . . . . 26

Nicholas Poppe, Jurchen and Mongolian. . . . . . . . . . . . . . . . 30

Mary Frances Weidlich, Этнографи versus Угсаaтны зүй . . . . . . . . . 38

Winston Wu, The Three Sorrowing Hills, Mongolia's First Opera:

An Examination of Literary and Musical Genre...... . . . 41

\section{History}

Frank B. Bessac, Impressions of Inner Mongolia, 1945-1950. . . . . . . . 54

Paul D. Buell, The Role of the Sino-Mongolian Frontier Zone

in the Rise of Cinggis-Qan . . . . . . . . . . . . . 63

Alicia J. Campi, Mongolia and Tibet in the Seventeenth Century:

The Nature of a Special Relationship . . . . . . . . . . . 77

Paul Hyer, The Role of Inner Mongolia in the Independence

Movement, 1911-1914............... 88

Sechin Jagchid, The Inner Mongolian Response to the Chinese

Revolution, 1911-1916. ............... 102

Georgeanne Lewis Reynolds, The Prehistory of Mongolia and the

Roots of Man in North America. . . . . . . . . . . . . . 112

Keith Scott, The Oyrot Under Manchu Rule: Social and

Administrative Policies. . . . . . . . . . . . . 121

Reports

John R. Krueger, The Activities and Publications of the Mongolia

Society (1978) and Mongolistic Activities at Indiana

University . . . . . . . . . . . . . . . . 130

Henry G. Schwarz, Man-kam Leung, and Michael Underdown, The

Bibliotheca Mongolica. . . . . . . . . . . . . . . 132

List of Participants . . . . . . . . . . . . . . . . . . . . 137 
LANGUAGE AND CULTURE 


\title{
PAST AND PERFECT IN MODERN MONGOLIAN
}

\author{
Robert I. Binnick \\ Scarborough College \\ University of Toronto
}

\section{Introductory.}

You may recall how in Stevenson's Treasure Island the "old sea dog" Billy Bones came to the Admiral Benbow Inn, thus setting off a series of events which led to the voyage of the ship Hispaniola to Treasure Island. Billy Bones' one great fear had been a blind sailor on a pegleg, who inevitably arrived one day to claim Bones' booty. Alas for Pew of the wooden leg and his confederates: Billy was already dead from rum; his hoard and his treasure map had gone with a very frightened Jim Hawkins. When Pew urged his men into the inn to look for Billy, bellowing in rage, "In, in, in!,"

Four or five of them obeyed at once, two remaining on the road with

the formidable beggar. There was a pause, then a cry of surprise, and

then a voice shouting from the house: ---

"Bill üxčixyee!"1,2 (Stivenson 28.2.2) 3 $^{3}$ In the original they shouted, "Bill's dead!"

There are two interesting points about the translation of "Bill's dead!" by "Bill üxčix̌ee!" The first is that the English present tense is being glossed by a Mongolian past tense. The second point requires us to look further ahead to that magnificent chapter wherein Jim encounters the unfortunate Ben Gunn who has been marooned for three years on the deserted island. Of course Gunn begs Jim to take him off and offers to lead him to the famous treasure if he will. But, as Jim recounts,

. . at this there came suddenly a lowering shadow over his face, and he tightened his grasp upon my hand, and raised a forefinger threatening-

ly before my eyes.

"Now, Jim, tell me true: that ain't Flint's ship?," he asked.

(Chapter 15)

To which Jim replies, "Flintijn xölög biš. Flint üxčixsen." (Stivenson 85.6.2) ${ }^{4}$ In the English he says, "It's not Flint's ship, and Flint is dead." Once again the English present becomes the Mongolian past, but in this instance, although the root $\ddot{u} x$ - and stem affix - čix- remain the same, the translator uses -sen instead of $-\breve{j e e}$.

Now why does this happen? We shall see that there is a method in the use of these two forms. In fact, this question is as good an introduction as any to the general question of the use of the Mongolian tenses, and specifically the three so-called past tenses, $-j e e,-e v$, and $-2 e e .5$ At one point (p.92) Sanžeev was led to state that "the differences between [the three past tense] forms, which are almost imperceptible, are still debated by students of Mongolian; the three past tense forms are used interchangeably." I do not think, however, that Sanzeev meant to say this, since elsewhere, for example in his book on the 
comparative grammar of the verb in Mongolian languages, he clearly shows that they are not used interchangeably and that the difference between them is hardly imperceptible. In fact, the three forms are quite different in use, and one of my purposes here is to describe their differences and to place those differences within the context of a linguistic theory. This is not to say that an adequate theory of tenses exists, but there are certainly valuable observations which can be made within a self-consistent framework.

Furthermore, as we have seen, there is a close connection between the so-called perfective ending -sen and these past tense endings. Is -sen (used predicatively) precisely equivalent to any one of these endings, or is it yet a fourth way of referring to the past? And if the English present (and perfect, as we shall see) can be translated by at least one of the past tense endings, in this case -jee, is there any distinction in Mongolian between the perfect and the past as tenses? My second purpose is to hazard an answer to this further question.

\section{Meaning and use.}

Let us start by demonstrating that the three past tenses are certainly not used interchangeably. First of all, every grammar book, including those written by native speakers in Mongolia, distinguish them. For example, the past (öngörsön $c a g$ ) is split up into the öngörön tögssön tense (the -ev form), the öngörön ürgelyilsen tense (the -jee form), and the sajaxan tögssön tense (the -lee form). 6 In my informant work with a native speaker these forms were likewise shown to differ in numerous ways, some of which I will return to later.

Supporting these distinctions is the evidence of translations from or into Mongolian. The -jee form is almost always coordinated with a present or the perfect which marks a result. Thus Vietze translates öngörü̈̈̈lyee 'ist stehengeblieben' (Vietze 26.3), and ene cag javaxaa bol'jee 'die Uhr geht nicht mehr. . . .' (Vietze 145.3).8 Poppe translates, however, baiď̃ 'es lebte' (Poppe 1955,188.1) and $x \vec{z} d \bar{z}$ 'veranstaltete.' 9 In translations of Turgenev, Cervantes, and Mao seems consistently to gloss forms equivalent to the perfect; 10 thus a sentence in Mao ending boloyee (Mao 3.5) ends in the English translation 'has brought' (I have not had the original Chinese checked). In the Treasure Is Land translation, - Jee is often used to gloss presents and perfects but also past tenses.

The -lee form also often glosses presents and perfects. Vietze translates namdlaa 'hat sich gelegt' (Vietze 32.4) and Poppe dürrlē 'ist zu Ende' (Poppe 1955, 190.7); the common expression bajarlalaa is roughly equivalent to our 'thank you' (Vietze $23.9 \mathrm{ff.}$.11 However, -lee has past and even future glosses as well.

While -ev can gloss or be glossed by present and perfect, as when Vietze translates juu bolovl2 (Vietze 19.6) by 'was ist los?,' a past translation is more usual, and in the literary language at least there is generally a careful distinction between, say, suusan, glossed by Vietze 'steckengeblieben' (Vietze 41.6) and suicixav, used to translate Turgenev (Sodov 340.12) where the English translation has 'sat down.'13

If further proof is required that the tenses differ, we need only consider their use in texts of different sorts. In folktales, for example, a great many sentences end in -Jee. Thus in the story Uran Guā Dagin (Poppe 1955, 188-223), of the first fifty sentences in the narration, excluding the gene 'they say' 
which is purely a narrative device, eighteen end in -yee, twenty-five in -ev, and seven in other endings. It is interesting to note that most of the -ev forms occurred within the scope of gene. On the other hand, in the quotes embedded in the story, -Jee is rare. Of the first fifty quoted sentences, only one ends in -jee, four in -ev, and forty-five in other forms. Clearly $-j e e$ is used here as a narrative-forwarding device. Compare this with the more descriptive style of newspapers, specifically Unen. 14 Here events in the past are almost as likely to occur with the ending -ev. In an article on the visit of a Russian dignitary to the Mongolian People's Republic (Montgomery 3-10), -ev ends four sentences, -Jee nine, and other forms (including several -Zee's) fifty. In the style of an author of a school textbook on foreign literature (Sandag), -jee is preferred over -ev for such statements as Tomas Mor. . . ömgö̈lögć bajjee 'Thomas More was an advocate' (Sandag 67) and 1564 ony 4 dïgeer saryn 23-nd törjee 'he [that is, Shakespeare] was born on April 23, 1564 ' (Sandag 68).

Are these purely stylistic devices? In part this may be so, just as our sportswriters, financial reporters, news reporters, and novelists prefer to use different perspectives in reporting events. 15 Yet underlying these various usages there must be real differences, just as there is a real difference underlying the virtual synonymity of "is he back yet?" and "has he come back yet?" in English.

There are more substantive facts that argue to a contrast in usage for the various past tense forms. First, all of the forms can be used in questions, and to each statement there is a corresponding question, e.g., ted suusan 'they sat,' ted suusan uu? 'they sat?' However, the questions, like the statements, do not serve the same purposes. WH-questions seeking information, e.g., juu bolov 'what happened?,' and yes-no questions, asking facts, e.g., Ene cin' Flintijn xölög ̈̈̈̈? (Stivenson 85.6.1) 'that gin't Flint's ship?,' more literally, 'this thing of yours, is it Flint's ship?, '16 take -ev. They are usually answered with -sen in the colloquial language; thus the answer to Ta xaanaas irev? 'Where did you come from?' might be Bi xotoos irsen 'I came from the city. 17 (Hangin 10).

On the other hand, - Zee is rarely used in questions. One example occurs when the rebelling (and superstitious) buccaneers, who have come to give Long John Silver the dreaded Black Spot, are chided by him for putting it on a sheet torn from a Bible:

"Ah, there!," said Morgan --- "there!

Wot did I say? No good'll come o' that,

I said." (Chapter 29)

In Mongolian Morgan asks rhetorically, "Bi juu ğej xellee?"18

While most of the grammars and studies I consulted have examples of - jee in questions, like those I am about to cite, examples of - jee in real questions seem uncommon in actual text. Consider Ramstedt's t'a unt'požu 'schliefen Sie (soeben)?' (Ramstedt 18); 19 Beffa's ter gare uu 'est-il sorti?' (Beffa 83); Kasjanenko's xaa očij 'kuda pošël?' (Kasjanenko 20). Hangin notes, however, that in asking Ter xooloo idej ü̈̈? 'Did he eat his dinner?' one is asking "Did you see or find out?," which differs from merely asking if he had eaten dinner. (Hangin 114) In fact, questions with -jee appear in texts mainly with the quotative verb ge- and are almost entirely either rhetorical or confirmationseeking echo questions, a notable exception in the texts being the folkloric 
ťsamad xamā baiď̃u 'Was geht es dich an?' (Poppe 1955, 152.5.2). 20,21 But in nearly all examples only gej occurs. At one point in Fathers and Sons (Chapter 27), for example, Bazarov asks his father for some caustic, saying that he had cut his finger and it might become (or already had become) infected. When he says that four hours have already passed, his father asks, "Didn't the district doctor have any lunar caustic?": . . . xošuuny eméid tomyn čuluu bajsangüj gej üï? (Sodov 360.3),22 suggesting that he cannot quite believe that he had not. Similarly, Chairman Mao inquires, "Have people not seen or heard about these facts?" (English version, p. 74) --- xümü̈̈̈s edgeer barimtuudyg duuly xaraagü j ge` ü̈̈? (Mao 77.4).23 Notice the negative in the English translations, suggestive of doubt, seeking confirmation: surely the doctor had caustic, surely everyone knows these facts. When he harangues his hostile crew, Long John Silver brings up their idea of killing Jim Hawkins. He says, "Are we a-going to waste a hostage? No, not us; he might be our last chance... . . Kil] that

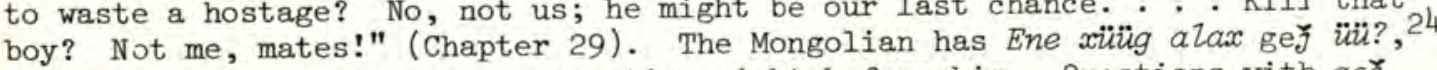
as if he were questioning a suggestion right before him. Questions with ge. often correspond to English questions with negatives 25 or which presuppose the hearer's previous statements or attitudes. 26

Yet other facts are clear indications of the differences between the tenses and are reflexes of those differences, often being cited in grammars in conjunction with descriptions of purported uses of the forms. Thus Poppe 1951 and Hangin, for example, observe that the -jee form usually occurs in the third person though, as we have seen, that is not invariably the case. Ramstedt, Poppe 1951, and Street observe that - lee is not used with a second person subject. In fact, in its "future" use it is rather restricted to the first person, though Mao has Impérialistuud urt naslaxgüj bolloo.27 (Mao 80.2) 'Imperialism (lit. imperialists) will not last long. . . .' There are no such restrictions on $-e v$ or $-s e n$.

A similar fact has to do with negation. Generally, in the modern literary and colloquial languages, no finite indicative tense form ever occurs negated, though in the literary language one occasionally sees the indicatives with the old negatives es or $\ddot{u} l .28$ Instead, participles with the ending -güij '-less' (from $\ddot{u} \ddot{u} \dot{j}$, 'without') are used. The three past tenses all are negated with -sen, the perfect particple, plus -güj. Thus when asked the negation of (la), the native informant gave (1b); a similar response occurred for (2). (1b) is of course the negation of (3).

(1a) End olon xün bajv. 'Here there were many people.'29 (Notes 14)

(1b) End olon xün bajsangüj .

(2a) Olon xün tend bajlaa. 'Many people were there.'

(2b) OZon xïn tend bajsangüj .

(3) End olon xïn bajsan. 31

It is interesting that while the -Jee form likewise usually is negated with $-s e n+-g \ddot{u} j$, the informant tended at times to negate it using the imperfect or continuous participle in -ee or the perfect converbal in -eed: 32

(4a) öglöö boljee. 'It became morning.'

(4b) Öglöö boloo(d)güj. 'It hasn't yet become morning.'

(5) Bi idee(d)güj. 'I haven't eaten yet.' (Notes 26) 33

Another interesting fact is that the so-called future use of -lee, like the non-past tense form in $-n e$, can be negated using the future participle or 
infinitive in $-e x$ : thus the informant negated $(6 a)$ as $(6 \mathrm{~b})$ :

(6a) Bi odoo javlaa. 'I'm going now.' (Said when you have not actually started. )

(6b) Odoo bi javaxgüj. ${ }^{34}$ 'Now I'm not going to go.' (Notes 22) 35 Note, however, that $(6 \mathrm{~b})$ while the negation of $(6 \mathrm{a})$, is not precisely its negation.

The foregoing arguments serve, I hope, to demonstrate that the verb forms in question do differ in use. But do they differ in meaning? There is good reason, in fact, to believe that they do not.

First, under negation, nominalization, and embedding, the distinction between the forms is neutralized, and the only past (or perfect) forms which occur are, respectively, the perfect participle in -sen and the perfect gerund in -eed. Thus all the statements in (7) receive, under general conditions, the negation (8), they all form relative clauses as in (9), they all nominalize as in $(10)$, and when embedded in an adverbial syntactic position, they all appear as in either ( $11 \mathrm{a}$ ) or ( $11 \mathrm{~b}) .36$

(7a) Luvsan irev.

(7b) Luvsan iř̌ee.

(7c) Luvsan irlee.

(8) Luvsan irsengüj. 'Luvsan didn't come.'

(9) Ter irsen xün Luvsan gedeg. 'The man who came is called Luvsan.'

(10) Irsenij $n$ ' bid medej bajna. 'We know that he came.'

(1Ia) Luvsany irsend, bid tend bajsangüj. 'When Luvsan came, we weren't there.'

(11b) Luvsan ireed, bid tend bajsangüj. 'Luvsan came and we weren't there. 137

Rather than analyze this as neutralization of semantic oppositions, we should say that some distinction is being lost and ask ourselves what sort of distinction can be, and is, lost in these positions.

If the forms in question differed in meaning, it ought to be the case that there were conditions undir which at least one of them would be true and at least one of them at the same time false; that is, there ought to be at least one situation describable by one alone of the three forms. If we examine the forms in question we see that in fact this cannot be. Any of the situations expressed by -lee or $-\bar{j} e e$ can be expressed by $-e v$. It may be that not every sentence with one or the other of these forms is directly translatable into one in -ev: there may be some adverbs, subject pronouns, etc., that can co-occur with $-\breve{e} e e$, say, but not with $-e v$. However, this need not imply a semantic difference.

As regards these two forms, they again do not describe distinct states of the world. If I say Luvsan iryee or Luvsan irlee, outside of context there is simply no difference: all we learn is that at some time in the past a man called Luvsan came. It is true that there are minor semantic differences between these forms, but I am concerned here with their central differences.

What we find is that the difference in use of these forms has nothing to do with the event described, as such, and those commentators who try to make it do so are wrong. Rather, as others have more correctly suggested, the difference is in the way the speaker views the event. If the event is something the 
Robert I. Binnick

speaker is vouching for, or is information which is well-known and stated not to convey new information but for another purpose, the -lee form may be used. If the event is presumptive or stated as suddenly acquired knowledge, the -jee form is used. $-e v$ is attitudinally neutral.

We can now explain the difference between our earlier examples üxčixyee and üxčixsen. It is not that the pirate in shouting "Bill üxčix yee!" is making any claim about the time of Bill's death or its nature; he is stating that Bill has died, thereby implying that he is dead, and incidentally informing us that he has just found out. (But in context we know this.) It would be odd for him to have shouted, "Bill üxčixlee!"; this presupposes that this is known already, not only to him, but to us. If he had shouted, "Bill üxčixev" or "Bill üxćixsen, "38 this would be a little odd, and probably would be more appropriate in a context where the question of Bill's death had already come up, though which he was, dead or alive, remained unknown. When Jim tells Ben Gunn that Flint is dead, üxcixsen, he merely states a fact; he neither assumes that Ben knows this nor does he state that it is new information to himself.

If we accept that the differences of use of these forms are not differences of meaning, but rather differences of what we should call discourse pragmatics, then we have a ready explanation for the contexts of their neutralization and for the highly marked nature of questions with these forms. It is the function of declarative sentences to make statements, but the force of statements may or may not be to provide new information. The function of questions may be to request new information, or it may not. Thus the questions in gey do not request new information any more than rhetorical questions in English do.

The importance of the sort of analysis I have just given is, as I see it, to enable us to clarify the problems of the past tense forms in Mongolian. For far too long there has been no attempt to provide argumentation or a theoretical underpinning for the rather vague and impressionistic statements of scholars, however correct or important these statements may be. I do not pretend, as I have said, to provide an adequate theory or a definitive solution, but I hope that I have turned the discussion in a new and, I hope, more fruitful direction.

\section{Perfect and past. ${ }^{39}$}

Let us return now to the perfect. My claim is that the use of terms like "perfect(ive) past" for the indicative forms is incorrect, and that they have no direct semantic content which such a term can explicate. At the same time I have admitted (a) that in numerous contexts -sen or -eed, the perfect(ive) verbal nominal (or participle) and gerund respectively, appear in place of the finite indicative forms, and (b) that in the colloquial spoken language -sen replaces $-e v$ in statements (though not in questions, where -ev contrasts with $-s e n)$. How is it, if the finite indicatives really lack semantic content, that -sen can replace them? And what about the distinction between past and perfect? Is it unreal? If not, what do these facts say about it?

Here we must observe that in fact the indicative forms do not completely lack semantic content. Even if they do not assert aspectual (and hence semantic) relations, they "implicate" them (here I am using a technical term). 40 For example, 
if I am involved in the discovery of a fact, it is likely that the fact has only recently come about. But it is no part of the meaning of the -jee form, say, that this is so. More importantly, though, all three past tenses do assert that the event, E, preceded the time of the speech act, S. Otherwise we should be able to use the present-future form. But while at any given point $\mathrm{S}_{i}$ it might be true, say, that Billy Bones will die, or is dying, it is not necessarily true at $S_{i}$ that he has died or even has been dying.

This explains how the past tense forms can be replaced by -sen and -eed, for these forms are purely aspectual, and merely assert that $\mathrm{E}$ preceded some other event $\mathrm{E}_{2}$. Normally the past indicative tense is used when $\mathrm{E}_{2}=\mathrm{S}$, but in the predicative use of $-s e n$ it can be assumed that $\mathrm{E}_{2}=\mathrm{S}$; there is an implicit copula even when bajna 'is' is deleted which, in the colloquial language, is normal in unmarked situations. Aspectually the finite forms and the non-finite differ only in the assumption that $\mathrm{E}_{2}=\mathrm{S}$. Thus - sen and $-e v$ are essentially fully equivalent, since -ev merely maps, atop the precedence relation of aspect, a relatively neutral temporality. Temporal oppositions, however, play no role in other than the positions finite verbs occur in, namely where they are used as main-clause verbs to make assertions, etc. (See Binnick concerning mainclause phenomena.)

I might note in passing that current semantics-based theories of tense can provide no explanation for these facts, since they do not refer to a relationship of $E$ to S. Furthermore, they do not take into account pragmatics at all. 41

This leaves us one final puzzle. In the modern literary language $-e v$ and predicative -sen are distinct in both declarative and interrogative sentences. Moreover, even in the colloquial language they are distinct in questions, since questions with predicative - sen do occur:

(12) Č nögöö emee uusan biz? Ene er emee uusan uu, ta min'? 'Did you take that medicine? Did he take that medicine, men?' (Stivenson 166.7.8; Chapter 30)42

(13) Xü̈ min', xaašaa javsan ve?43

'Which way [was he walking], sonny?' (Stivenson 11.2.1; Chapter 2) 44

(14) Bìe agzajł čičirsen ü̈̈?

'Have you had chills, too?' 45 (Sodov 360.16.1; Chapter 27) 46

What these examples clearly show is that the -sen form has a distinction from the preterite that we have not mentioned, and that this distinction is always indicated in questions, though it need not be in statements. With uu, -sen is used roughly like the English perfect to indicate an event which happened prior to $\mathrm{S}$ but at no definite time, whereas -ev points to a definite point in time as in the following examples; thus some scholars, e.g., Bosson, refer to the $-e v$ form as the "definite past tense."

Compare the following examples: ${ }^{47}$

(15) Či öčigdör nom unšiv uu?

'Hast du gestern ein Buch gelesen?' (Vietze 44)

(16) Mitjuxa ene erxem saja čamajg juu gej xočilsnyg duulav uu?

'D'you hear that, Mitya? . . . Hear what the gentleman called yer?' (Sodov 345.7.1; Chapter 2) 48

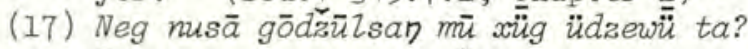

'Haben Sie einen erbärmlichen Bengel gesehen, dem Rotz aus der Nase heraushängt?' (Poppe 1955, 192.2.12)49 
(18) Xāgūr xāgūr jowaď̃, sonin saixan jum dülwū?

'Wo bist du gereist? Hast du [auch] irgend etwas Interessantes und Gutes gehört?' (Poppe 1955, 208.2.5) 50

In (15) öcigdör provides a definite context; in (16) the just-uttered statement provides the definite context; (18) is uttered in the context of a previous statement concerning the hearer's travels. Even (17) may be explicable in terms of a definite period of time, since it doesn't mean "have you ever seen. . . .," etc., but applies to a certain pragmatically defined stretch of time.

It should not surprise us that predicative -sen should differ in this way from $-e v$, which is neutral relative to -jee and-lee, but clearly has this additional force. Nor should we be surprised by the loss of the distinction in statements which happens elsewhere, e.g., in American English where "went" can mean "has gone," although a precise explication of this demands further study.

\section{Conclusion.}

I have been concerned here with investigating the uses and mutual relationships of four forms used in Mongolian today to refer to events in the past. If I have done nothing else, I hope that I have demonstrated that these forms do not contrast in the time of the event referred to, nor in its aspectual nature, but basically differ in the discourse pragmatic function to which the speaker puts them. I hope that now we can begin to develop a deeper and more soundly established theory of the Mongolian, and hence the Altaic, verb system. 51

\section{Notes}

1. Examples from the modern literary language in Cyrillic script have been transliterated as follows, the Cyrillic letters becoming, respectively,

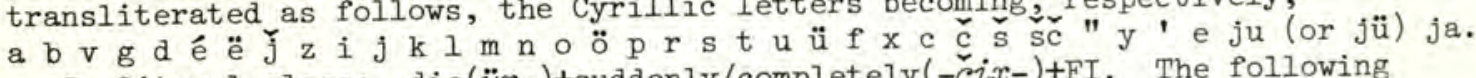

2. Literal gloss: die( $\ddot{u} x-)+$ suddenly/completely(-cix-)+FI. The following symbols and abbreviations are used in the literal glosses:

$+$

or

abl ablative

acc accusative

caus causative

CL converbal (gerund)

com comitative

cop copula

dat dative

FI finite indicative ending

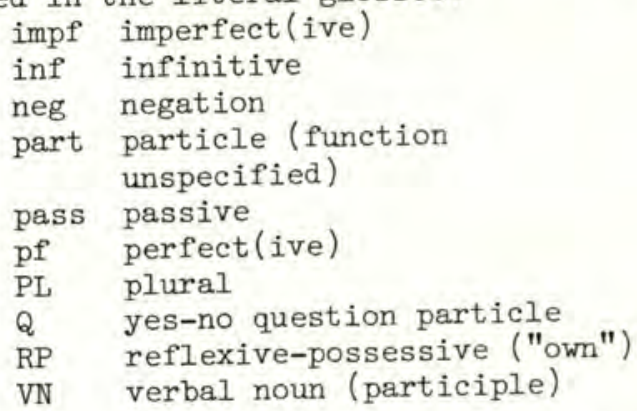

gen genitive

3. The sources are given at the end of the paper. Generally the first number is the page, the last the sentence or example, and the middle, if any, the paragraph. I have given only the chapter or section for non-Mongolian texts where editions will differ in pagination.

4. Gloss: Flint+gen(-ijn) ship not. Mongolian omits the present cop here. 
-sen is literally a pf VN; strictly speaking a present auxiliary cop has been deleted here, but in the colloquial language, at least, -sen is often used predicatively and, as we shall see, normally substitutes for the past in -ev.

5. - Jee does not change for vowel harmony; $-e v$ and -lee have four forms each,

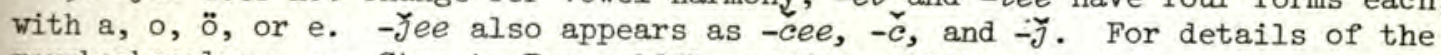
morphophonology, see Street, Poppe 1951, or Poppe 1970.

6. Literally, 'completed passing,' 'prolonged passing,' and 'just completed.' Slight variants of these terms are cited by several authors, e.g., Vietze, Beffa, and in various Mongolian publications, e.g., Š. Luvsanvandan, ed., Orčim Cagijn Mongol Xel Züj (Ulaanbaatar, 1966), pp. 148-153.

7.. Yidamjab Meng.

8. öng̈rü̈̈ll- is actually the caus (-üül-) of öngör- 'pass.' Gloss of second example: this clock go(jav-)+inf $(-a x)+R P$ cease $\left(b o l^{\prime}-\right)+F I$.

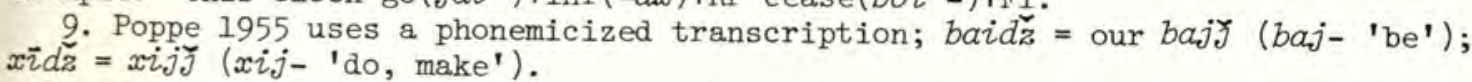

10. I have not investigated the originals, but this seems true from an examination of the corresponding English translations.

11. Bolgo- is the caus of bol- 'become, happen'; namd- 'calm down'; düür(cf. note 9) 'end, stop'; bajarla- 'rejoice' (cf. bajar, 'happy').

12. Gloss: what happen $+F I$.

13. suu- 'sit, live'; -čix- 'suddenly/completely.' It should be noted that this stem affix also occurs with -sen, as we saw with üxčixsen. The form in $-s e n$ has numerous non-predicative uses; $-e v$ is only predicative. In its nonpredicative uses, $-e v$ is unambiguously a perfect, i.e., öngörsön J̆i means 'last year; the year (which is) past/has passed.' However, even here a preterite gloss is possible, e.g., tend suusan xün 'person who sat there.'

14. This is the Mongolian equivalent of Pravda; its name likewise means 'truth.'

15. See pp. 191-192 in Sanzeev's Sravnitel'naja Gramatika Mongol'skix Jazykov -- Glagol (Moscow: Izd. Vostocnoj Literatury, 1963) concerning the "free" use of the -jee form as a purely stylistic device. For the "free" use of tenses, an interesting article on another Altaic language is Ozcan Baskan's "Interchangeability of tenses in colloquial Turkish" (Litera 9, Ankara, 1968), pp. 4-8. Also in H. E. BrekIe and L. Lipka, eds., Wortbildung, Sprache, und Morphologie
(The Hague: Mouton, 1968).

16. Omgöölö- 'defend'; -gc is the agent nominalizer. Glosses: 1564 year+gen $(-y) 4+-$ th month $(<$ moon $)+\operatorname{gen}(-y n)$ ( 4 th month = April) on-the-23rd (23-nd) be-born $\left(t_{0} r_{-}\right)$. They sit/livetpf-VN; they sit/livetpf-VN Q. What happen+FI. This your Flint+gen ship Q.

17. Glosses: you(PL) wheretabl (with $-n-$ ) cometFI. I citytabl cometpf-VN.

18. Gloss: I what gey (quotative particle) say+FI.

19. = our ta untaj uu. Gloss: you(PL) sleep+FI Q.

20. Glosses: he(lit. the/that-one) go-out+FI Q; where go-to+FI; he food/meal +RP eat+FI W. Poppe's example is čamad xamaa bajj uu. Gloss: youtdat affair be+FI $Q$. Here 'be'+dat = possessive, 'do you have any affairs?'

21. James Bosson in a personal communication suggested these might be impf CL forms in elliptical sentences. This is certainly possible, as the two forms are identical. However, the existence of -yee questions cited by various authors plus the distribution of the questions in dispute suggests that they are not elliptical; certainly the glosses do not suggest this.

22. Xošuu(n) 'district' + gen(-y); emč 'doctor'; tamyn čuZuu is lit. 'stone of hell' (Iunar caustic is silver nitrate); bajsangüj 'hasn't been'; gej 'saying'; aiu is Q. 
23. Gloss: people these fact+PL $(-u$ ud $)$ acc heartimpf-CL seetimpf-VN say/mean $(g e-)+F I$ Q

24. Gloss: This boytacc(-g) kill(aZ-)+inf say/mean+FI Q.

25. Thus in Stivenson 51.8.6 Ted tusgüj dalajeid gej ü̈̈? 'Are they not good seamen?' (literally: they useless seamen gej Q). Here the question is asked by $\mathrm{Dr}$. Livesay, attempting (Chapter 9) to clarify what Captain Smolett is saying about the crew of the Hispaniola. "You say you don't like the crew," he summarizes and then asks the captain this question.

26. Thus in Chapter 30 (Stivenson 169.8.2). Dr. Livesay visits Jim who is held by the pirates as a hostage; he is allowed to talk to the doctor on his honor not to escape. Jim suggests that he be abandoned to save $\mathrm{Dr}$. Livesay and the others and tells the doctor where he has the ship hidden. The doctor says, "There is a kind of fate in this. . . . Every step, it's you that saves our lives; and do you suppose by any chance that we are going to let you lose yours?" (Xü̈̈ min', bid camajg busdyn gart aluulna ge ü ü̈̈?; lit.: boy we youtacc othertgen $(-y n)$ hand+-ed kill+caus(here = 'let')+FI. This is a rhetorical question, pretending to assume that Jim does indeed think so.

27. Gloss: Imperialist+PL(-uud) long-time enduretinf $(-a x)+$ neg becometFI. As past forms of bol-can be interpreted with present sense, this is not clearly a "future" use.

28. For example, bi tand es xelzü̈, ezen min'! 'Did I not tell your Grace. . . . (Sodov 83.10) Note the use of xellee, here shortened to xell- before $\ddot{u} \ddot{u}$ in a question. Lit.: I you(formal)+dat neg(es) say/tell+FI+Q, lord-my. An interesting example where es occurs before a CL-main verb combination is

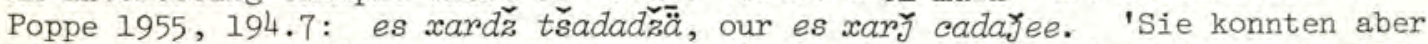
nicht schauen.' ('They could not look.') Lit.: neg look+impf-CL be-abletFI. Another example of es occurs at Stivenson 138.4.3. Öl occurs several times in Mao (16.3, $18.5,62.5,62.9$, etc.) with non-finite forms.

29. The word order here is significant as to the relative discourse importance of the modifiers. End olon xün bajv means 'here there were many people.' 'Many people were here' would be olon xün end bajv. I believe this is ambiguous as to whether a definite or indefinite group is meant.

30. 'Notes' refers here to my informant work notes of 1977. I have written elsewhere of the value of informant work and of the great difficulty of interpreting its results. Use 'Notes' examples with caution.

31. End 'here,' olon 'many,' xün 'person,' baj- 'be.'

32. It is unusual for the converbal to be used non-elliptically predicatively,

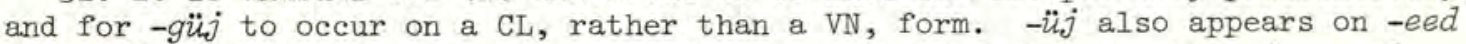
for -güj. Apparently there is no difference in meaning between this form and the one with -eegüj.

33. ÖgZ88 'morning,' bol- 'become,' $i d$ - 'eat,' bi 'I.'

34. Bi 'I,' odoo 'now,' jav- 'go.'

35. There is an apparent difference in adverbial scope here, perhaps relating to a pragmatic difference. In (6a) odoo modifies jav- 'go'; but in (6b) the entire sentence is within the scope of the adverbial, which expresses a sort of presupposed state of affairs. Thus the examples may not be strictly comparable, but this should not affect the basic argument.

36. I am writing here as if there were transformation of one form into another in these cases. There is reason to believe, however, that this is not the case, that the nominalized forms, for example, are equally basic and underlying as the indicative ones. See Binnick for a discussion. This does not, however, affect the argument here. 
37. Glosses of (9-1Ib):(9) the cometpf-VN person Luvsan is-usually-called; (10) cometpf-VNtace the/his we knowtimpf-CL betFI; (1la) Luvsantgen cometpfVN+dat, we there betpf-VN+neg; (IIb) Luvsan cometpf-CL, we there betpf-VN+neg.

38. Usually a preterite assumes a definite time, whereas a perfect does not. Thus in British English "he went home" cannot answer (i), though it can answer (ii); "He's gone home" can answer (i), but not (ii).

(i) Where's Bill? (I don't see him.)

(ii) What did Bill do when Sue stood him up for their date?

(She was supposed to meet him at the club.)

I am not certain whether $-e v$ and $-s e n$ differ in this way in either the colloquial spoken or the more literary written languages of today.

39. The details of the pragmatic conditions on the use of the tense terms are omitted in this version. They are being prepared for a future, complete version of this paper.

40. "Implicate" is used here in lieu of "imply" to indicate that the implication is by certain types of logical principles called "implicatures." See, e.g., Ruth M. Kempson, Presupposition and the Delimitation of Semantics (Cambridge: Cambridge University Press, 1975).

41. I am thinking of both theories in the tradition of Otto Jespersen's Language and Hans Reichenbach's Elements of Symbolic Logic, and logical theories, be they model-theoretic approaches to natural language or modal/temporal logics. Recent work by Elizabeth Ridale promises, however, to provide a pragmatic theory of tense with considerable explanatory power. A fuller discussion will be provided in the final version of this paper.

42. Či 'you,' nögöö 'this, that,' emee 'own medicine,' uu- 'drink,' biz (copular particle with a certain pragmatic force of supposition), ene 'this,' er 'man,' ta 'you,' min' 'my.'

43. Ve is described (Poppe 1951, 96) as a "copula" used in WH-questions. Its precise syntactic analysis is unclear, though Street $126 \mathrm{ff}$. treats it as merely an interrogative particle like uu. He does note, however, that it usually appears in truncated sentences--thereby suggesting a treatment like Poppe's-though he also gives examples with copula, e.g., nom xaa bajna ve? 'where's the book?'

44. Xü̈̈ 'boy,' min' 'my,' xaašaa 'where to,' jav- 'go.'

45. Here the English translation is more useful than the Russian original, since the past ending in Russian also has perfect meaning.

46. Biée 'body/self,' agzaj- 'shiver,' čičir- 'tremble with cold,' üü Q.

47. Cf. the following example where bolov, although past, really has present force: Tany aldar nerijg medey boloxson bolov uu? Lit.: your family-name nametacc $(-i j g)$ knowtimpf-CL become+inftperfect become+FI Q. 'May I ask your name and patronymic?' (Sodov 344.9.3; Chapter 2). Cf. Poppe 1955, 188.2.9, 188.5 .4 .

48. Či 'you,' ̈̈čigdör 'yesterday,' nom 'book,' unš- 'read,' ene 'this,' erxem 'gentleman,' saja 'just now,' čamajg 'you'(acc), juu 'what,' gej̆ 'saying,' xočil'give a nickname to' + pf-VN+acc $(-y g)$, duul- 'hear.'

49. = our Neg nusaa goőuulsan muu xü̈g üzev ü̈ ta? one mucous+RP driptcaustpfVN bad boytacc seetFI $Q$ you(PL). The ta is a postponed subject, not merely a vocative. This is a rare exception to the rule that nothing can follow the Q.

50. = our Xaaguur xaaguur javał, sonin sajxan jum duulav uu? where where gotimpi'-CL news fair thing hear+FI Q

51. I would like to thankfully acknowledge the assistance of Mr. Yidamjab 
Meng which contributed much to this work. It has been a pleasure to have the opportunity to pick his brains and native intuitions.

At the conference a number of interesting comments were made on the paper. Two by Professor Poppe are worth noting here. First, with the -jee form there is sometimes the sense "it turned out that" or "it turned out after all that." The second comment was that example Ene cag javaxaa bol' Jee is literally 'has ceased to work' and could equally well have been glossed "hat aufgehört zu gehen." He went on to say that often there is an interchange of meanings, as regards such Mongolian examples in English or German gloss, between present, perfect, or even preterite tenses. I thank all who had observations to make during the discussion period.

\section{References}

Beffa, Marie Lise, and Roberte Hamayon. Eléments de gramaire mongole. Paris: Dunod, 1975.

Binnick, Robert I. "On the underlying tense of deverbatives," Language 54:2 (1978), pp. 289-299.

Bosson, James E. Modern Mongolian: A Primer and a Reader. Bloomington, 1964. (Uralic and Altaic Series, v. 38).

Hangin, John G. Basic Course in Mongolian. Bloomington, 1968. (Uralic and Altaic Series, v. 73).

Kasjanenko, Z. K. Sovremennyj Mongol'skij Jazyk [The Contemporary Mongolian Language]. Leningrad: Leningrad State University, 1968.

Mao Tse-tung. Darga Mao Czedungijn Ügijn Tüüver [A Selection of the Sayings of Chairman Mao Tse-tung]. Peking, 1972. English version is Quotations from Chairman Mao Tse-tung, Peking, 1966.

Montgomery, David C. Mongolian Newspaper Reader. Bloomington, 1969. (Uralic and Altaic Series, v. 102).

Notes $=$ my informant research notes of 1977 . See note 30 .

Poppe, Nikolaus. Khalkha-mongolische Gramatik. Wiesbaden: Franz Steiner Verlag, 1951.

Poppe, Nikholas. Mongolian Language Handbook. Washington: Center for Applied Linguistics, 1970.

Poppe, Nikolaus. Mongolische Volksdichtung. Wiesbaden: Franz Steiner Verlag, 1955.

Ramstedt, G. J. Über die Konjugation des Khalkha-Mongolischen. Helsingfors, 1903. (Mémoires de la Société Finno-Ougrienne, v. 21).

Sandag, c. Gadaadyn Uran Zoxiol [Foreign Literature]. Ulaanbaatar: BNMAU Gegeerlijn Jamny Xevlel, 1967.

Sanžeev, G. D. Moderm Mongolian Language. Moscow: Nauka, 1973. Translated by D. M. Segal from Sovremennyj Mongol'skij Jazyk, 1959.

Sodov, D., ed. Gadaadyn Uran Zoxiolyn Unšix Bičig [Foreign Literature Reader]. Ulaanbaatar: BNMAU Gegeerli.jn Jamny Xevlel, 1967. For Turgenev glosses, see Turgenev.

Stivenson, R. L. Erdene Bulsan Aral [Buried Treasure Island]. Ulaanbaatar: BNMAU Ardyn Bolovsrolyn Janny Xevlel, 1975. Translated by D. Altanxujag from Robert Louis Stevenson, Treasure Island.

Street, John C. Khalkha Stmucture. Bloomington, 1963. (Uralic and Altaic Series, v. 24). 
Turgenev, Ivan. Fathers and Sons, tr. by Bernard Isaacs. New York: Washington Square Press, 1962.

Vietze, Hans-Peter. Lehrbuch der mongolischen Sprache. Leipzig: Verlag Enzyklopädie, 1969. 


\title{
A PROBLEM IN BURYAT HISTORICAL LINGUISTICS
}

\author{
Larry V. Clark \\ Indiana University
}

The Buryat Mongols are among those peoples of Siberia who may be said to lack historical profile prior to the early seventeenth-century conquest of Siberia by Tsarist Russia. Ethnonyms and toponyms with supposed connections to the Buryats rarely occur in earlier Asian sources, and those that do are attended by ambiguity. Behind this historical obscurity follows the dark course of the Buryat language, which began to be recorded only in the eighteenth century when it had already by and large assumed its modern form. Lacking earlier concrete data, we might presume that the investigation of the historical development of Buryat belongs to that kind of intellectual puzzle whose solution depends on arguments that cannot be supported by facts.

The present paper addresses only a fragment of this puzzle, namely, the Buryat developments of Mongol $s, \check{c}$, and $\breve{j}:^{1}$

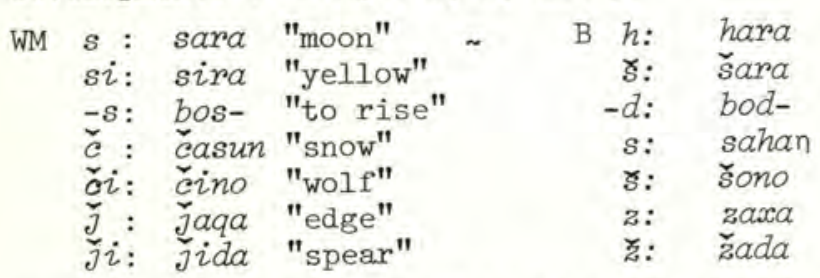

These developments highlight that distinctive shape which all Buryat dialects share in contrast to other Mongol languages, and which is already characteristic of Buryat in the eighteenth century.

Thus we know the starting and the ending points of these developments, but on the face of it the lack of earlier data might seem to preclude knowing when these developments occurred. The present paper addresses the problem of the chronology of these developments, and attempts to outline a research strategy that takes into account various kinds of later linguistic sources for Buryat whose utilization may partially compensate for the absence of earlier materials.

Several assumptions may be made in regard to these developments. The first is that there were intermediate stages between the starting and the ending points, specifically:

\begin{tabular}{|c|c|c|c|}
\hline & $>$ & $* \theta$ & $>$ \\
\hline si & $>$ & $\star \check{s} i$ & $>$ \\
\hline$t \check{s}$ & $>$ & $\star_{c}[t s]$ & $>$ \\
\hline$J[d z$ & $>$ & $* j[d z]$ & $>$ \\
\hline & $>$ & $* c \mathrm{c} V$ & $>$ \\
\hline 6 & $>$ & $* \check{y} \mathrm{~V}$ & $>$ \\
\hline
\end{tabular}

Evidence will be cited below that supports the intermediate states for $\check{c}$ and $\breve{y}$, 
while the others are postulated on the basis of probable phonetic developments.

A second assumption that is made is that the developments of the affricates occurred in tandem; in other words, the changes which affected $\check{c} / \widetilde{c} i$ affected $\bar{J} / \bar{j} i$ in the same way and at the same time. This assumption is based on the fact that these affricates begin and end with the same primary phonetic shapes (differing only in the secondary feature of voicing) and thus ought to have followed parallel developments.

Furthermore, it may be argued that at least some of these developments occurred in a certain order relative to one another, that is, that they may be arranged in a relative chronology: (1) $s i>r$ occurred before $s>h$; otherwise, si would have become $h$ as well (*hara < hira < sira, rather than šara); (2) $s$ > $h$ occurred before $\check{c} / \breve{s}>s / z$; otherwise, $\check{c}$ would have become $h_{-}$as well (*hahan <

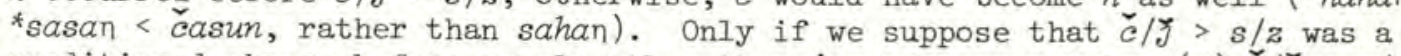
conditioned change before vowels other than $i$ can we postulate: (3) $c / J>s / z$

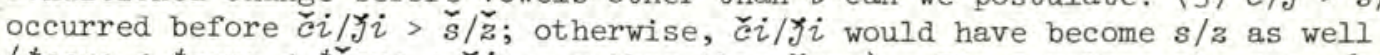
(*sono < *ono < *cono < čino, rather than šono). The development $-s>-d$ cannot be ordered in this way, but in view of the existence of this development already in Middle Mongol (just as "i-breaking" and the contraction of disyllabics to long vowels in Buryat), it potentially existed as a feature of the Mongol dialect base from which Buryat evolved. Thus, preliminary to its further discussion below, $-s>-d$ may be placed at the beginning of this ordered arrangement.

As a consequence of these considerations, the Buryat treatments of $s, \check{c}$, and $J$ may be arranged in the following relative chronology where (4) is divided into two stages for reasons that will be evident below:

$$
\begin{aligned}
& \text { (1) }-s>-d \\
& \text { (2) } s i>* \check{s} i>\check{s} \\
& \text { (3) } s>*^{*}>h \\
& \text { (4a) } \check{c} / \bar{j}>*^{*} c / j \\
& \text { (4b) } * c / j>s / z
\end{aligned}
$$

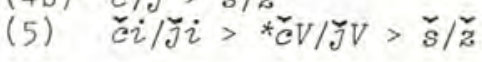

For the evidence that might enable us to assign some of these changes to specific periods in time, we turn now to an examination of each of the linguistic sources of Buryat.

\section{Written Mongol Among the Buryats}

In the late seventeenth and early eighteenth centuries Lamaism was propagated by Oirat and Southern Mongol clergymen among the leading tribes of the TransBaikal area: the Khori Buryat who migrated there from the Sis-Baikal in the seventeenth century; the Mongols of the Selenga River area, essentially the Congol and Sartuul who were emigrants from Mongolia; and the Barguzin Buryat, originally Ekhirit Buryat from the Sis-Baikal, who began to settle the Barguzin area in the seventeenth century. One of the significant consequences of the spread of Lamaism among these tribes was the introduction and adoption of the Written Mongol literary language.

The first mention of the existence of this literary language among the Buryats is located in the Noord en Oost Tartarye (1692) of Nicolaes Witsen who remarked 
that "the Bratsi have a special writing, although few of them know how to read."2 A number of texts in this "special writing" (i.e., Written Mongol) have been edited or studied, from which it is evident that many manuscripts reflect Buryat phonetic shapes, grammatical forms, and lexica, that appear at the indiscretion of their scribes, in the otherwise Classical literary language in which they were written. 3 While the importance of this body of texts for aspects of later Buryat linguistic history is incontestable, it is the case that no manuscript datable to before the late eighteenth century has yet come to light, so that this source cannot be utilized for the present problem.

\section{Early Western Recordings}

It was noted above that Buryat had developed in most respects its characteristic modern shape by the eighteenth century. Our witness to this consists of some stray recordings made in 1723 by Daniel Gottlieb Messerschmidt and of several glossaries passed on in the compilations of Johann Eberhard Fischer (ca. $1730)$ and Peter Simon Pallas $(1786-1789) .4$ of these, the Fischer glossary is especially important as it reflects in a relatively systematic fashion a Western Buryat dialect that is unambiguous in regard to most of the developments which concern us: (1) $-s>-d$, cf. F totcho "clay," B tōdxo "a fine dust," WM torosqa "brick"; (2) si > s, cf. F schara "yellow," B šara, WM sira; (3) s> h, cf. F chakal "beard," B haxal, WM saqal; (4) $\check{c} / \zeta>s / z$, cf. F sjagun "snow," B sahan, WM časun $;^{5}$ (5) či $/ \breve{j} i$ remains $\check{c} / \bar{J}$ in Fischer, but Messerschmidt reflects the change $\check{c} i$ > s (schonno "wolf," B కono, WM čino; guschyn "30," B gusan, wM rutin), while for $j i$ it may be that Messerschmidt's spelling dsh represents $\check{z}$ (dsheron "60," B こ̌ran, WM Jiran; nadshir "summer," B nažar < *nă̌r ). 6 Taken together, then, Fischer's and Messerschmidt's recordings establish that the major sound changes characteristic of all modern Buryat dialects were already in existence in the Western Buryat dialect area in the 1720 s.7

\section{Dialects}

Although numerous problems and issues in Buryat dialectology remain unresolved, we are in possession of basic monographs describing the major dialects. Without violating general views toward their classification, Buryat dialects may be divided into the following groups: ${ }^{8}$

I. Western: Ekhirit and Bulagat, with Bokhan and Barguzin (where $\check{z}>y$, cf.

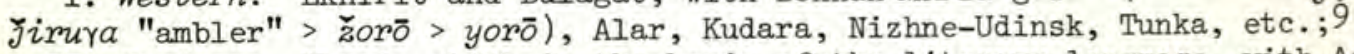

II. Eastern: Khori, which is the basis of the literary language, with Aga, Ivolga, and other sub-dialects;10

III. Southern: Selenga, consisting of Congol and Sartuul; Bargu. ${ }^{11}$

One might suppose that those dialects which have participated in all the major Buryat changes, and which are spoken by ethnic groups who are core components of the present Buryat people, would be those dialects most pertinent to problems of the historical development of Buryat. However, it is the case that the Congol dialect, which linguistically stands closest to Khalkha, provides us with a key to the solution of the chronology of one of the Buryat changes.

An important aspect of Congol is that it is spoken by people whose movement out of Mongolia into the Selenga region may be dated with some precision. It 
is known, both from Russian administrative documents and from historical chronicles composed by the Selenga Buryats that the Congol clans migrated into the Selenga area in the contact zone with the Buryat language in the 1680s, largely as the result of the war between the Oirat prince Galdan Bušugtu and the Khalkha prince Sayin Khan.12 Another important facet of Congol is that in the seventeenth and eighteenth centuries it belonged to the Khalkha dialect group according to features which it still retains: (l) $s$ remains $s$ in Congol, Khalkha sara "moon," but B hara; (2) $\check{c} / \tilde{j}$ become $c / j$ in C, Kh cever "clean, pure," but B seber, and C, Kh jujjän "thick," but B zuzan; (3) či/ צ̆i remain in C, Kh čono "wolf," but B కono, and C, Kh Jorō "ambler," but B こ̌orō.13 The Buryat influence on Congol shows up in certain phonetic details $(-s>-d)$, and more pronouncedly in the lexicon.

One element of the latter kind of influence is the postposition--perhaps better described as an enclitic--co, which has in Congol an inessive-illative function meaning "in, within"; e.g., c gercō "within the house."14 This enclitic, in the form sō and with the same function, is found in all Buryat dialects, but in no other Mongol language. 15 Consequently, its appearance in Congol may unequivocally be interpreted as a borrowing from Buryat. Moreover, on the basis of the initials of $\bar{c} \bar{o}$ and $s \bar{o}$, the immediately preceding form * ${ }^{\circ} \bar{o}$ may be postulated.16

What makes the Congol reflex of this enclitic so significant is that its adoption from Buryat can be dated to the period after the 1680 s when the Congols moved into contact with Buryat. Congol cō cannot have been borrowed from Buryat $s \bar{o}$, that is, after the latter had undergone the change $\check{c}>s$, because in that case Congol would have the form sō, since Congol had and has the phoneme $s$. Nor should it have been borrowed from the reconstructed Buryat * čó at a stage before Buryat had made the change $\check{c}>s$, because in that case Congol would have the form $\check{c} \bar{o}$, as the phoneme $\check{c}$ has always existed in Congol.

Therefore, the only possible inference to be drawn from Congol co is that it was borrowed from Buryat * ${ }^{*} \overline{\text { }}$. With this we are in a position to establish two facts of Buryat linguistic history:

(1) the intermediate stage $\check{c} / \breve{J}>c / j$, which was postulated as (4a) above, was a reality in the Buryat dialect area at some point after the 1680 s (CongolBuryat contact) and before the 1720s (Fischer-Messerschmidt);

(2) the sound change (4b) $c / j>s / z$ occurred between the $1680 \mathrm{~s}$ and the $1720 \mathrm{~s}$, since its starting point is entailed by the Congol reflex co and its ending point is attested in the Fischer-Messerschmidt recordings.

\section{The Buryat Element in Yaqut}

Among the problems connected with the Mongol elements in Siberian Turkic languages, 17 none is more pertinent to the present theme than the Mongol borrowings in Yaqut, at least one layer of which was thought to be of Buryat origin by the chief investigator of this question, S. Kałużynski.18

The Mongol loanwords in Yaqut display two reflexes of Mongol $\check{c} / \breve{\jmath}$ :

(a) $\check{c} / \breve{\jmath} \rightarrow s$; cf. Y sugulān "assembly" $\leftarrow \mathrm{M}$, WM čurZaran, B suglā̄n; Y szarra

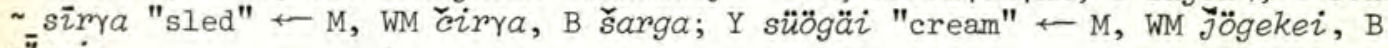
$x \overline{0} x e i$;

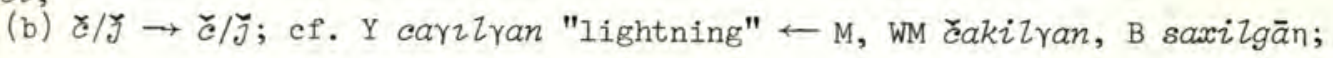


Y bičik "decoration" « M, WM biěig "writing," B bešeg; Y Jorus jaras "suit-

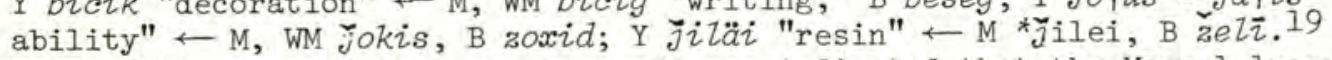
Kałużýski supposed that the two reflexes indicated that the Mongol loanwords entered Yaqut from different Mongol dialects; that, since Mongol č/ $/ \breve{j}$ become sibilants $s / z / \check{s} / \check{z}$ only in Buryat, layer (a) must be the Buryat layer in Yaqut; and that the Buryat layer is the most recent. 20 According to this view, then, Yaqut is a potential source for the linguistic history of Buryat.

However, it can be shown with some clarity that a different interpretation of the two reflexes of Mongol $\check{c} / \bar{j}$ must be correct. In the first place, the fact of intensive contact between predecessors of speakers of Buryat and Yaqut is indisputable. This is nowhere more evident than from the example of the designation of the "rainbow" in the two languages: B ünegen šektete and Y sasz iktäbit, literally "the fox pissed."2l Here the parallel expressions which employ native words imply a connection that is deeper than ordinary borrowing, namely, the common conceptualization of an atmospheric phenomenon. Because this conceptualization is unknown elsewhere in Siberia, it is possible to infer some period of community among peoples who later formed components of the Buryats and the Yaquts. 22

Even among the Mongol borrowings in Yaqut, it is possible to detect specifically Buryat loanwords: Y Jârsın "thin; book" $\leftarrow$ B *č̄arsan > sarhan, cf. WM čarasun, Middle Mongol ča'alsun, Kalmyk cāsn, Ordos čāsu, Khalkha cās(an); Y Jon "people" « B * ־on > zon, a word that is not found in other Mongol lan-

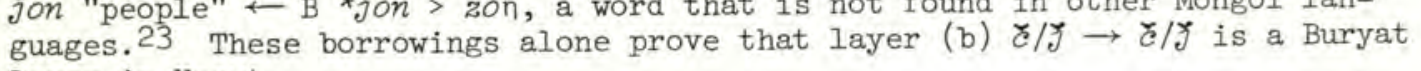
layer in Yaqut.

The status of layer $(a) \check{c} / \breve{J} \rightarrow s$ must be evaluated in light of the sound changes which affected the Turkic portion of the Yaqut lexicon. By the time of the compilation of Witsen's Noord en Oost Tartarye (1692), but undoubtedly several decades earlier, a small Yaqut word had been recorded that already reflected the major Yaqut sound changes, including the change $r / x>s$ in all positions:

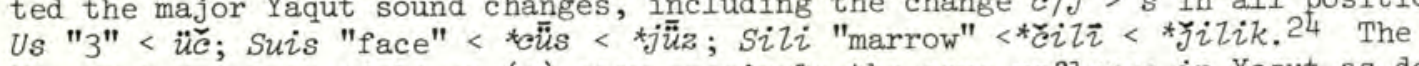
Mongol borrowings of layer (a) show precisely the same reflexes in Yaqut as do the native Turkic words, from which it may be inferred that layer (a) existed in Yaqut prior to the Yaqut sound change $\tau / J>s$ and, of course, prior to the entrance of layer (b). 25

As a result of these considerations, it can be seen that layer (a) borrowings which, it goes without saying, are probably also to be attributed to those Mongol dialects which formed modern Buryat, 26 cannot be utilized as a source for the present problem since internal Yaqut developments served to "mask" the original phonetic shapes of the borrowed words. Layer (b) borrowings, which are demonstrably Buryat, cannot be assigned even an approximate absolute chronology due to the still obscure historical relationship between the Buryat and Yaqut peoples. On the positive side, however, it has been established that layer (b) reflects a stage of Buryat that existed prior to the operation of the sound changes which concern us here.

\section{Buryat Loanwords in Evenki}

Several dialects of Evenki, a Northern Tungus language, are spoken on the territory of modern Buryatia. $7^{2}$ of these, only the dialect of the Barguzin 
Evenki has been described in any detail, from which it is clear that it contains a substantial number of words borrowed from Buryat. 28

One of these borrowings has immediate significance for the present problem. 29 The name for the Russian Tsar in Barguzin Evenki is cagān kān, which represents Mongol caran qaran "White Khan." 30 Since this term should not have come into existence prior to the first penetration into Buryatia by the Russians in the 1620s, we may infer from its presence in Barguzin Evenki that a form *éagān existed in Buryat between the 1620s and that point in the period between the 1680 s and the 1720s when a form * cagān would have regularly developed in Buryat (see above under Dialects).

\section{Written Mongol Elements in Buryat}

Although it is probably true that the use of Written Mongol accompanied the introduction of Lamaism among the Buryats at the end of the seventeenth century, it is at least possible that Written Mongol was known in this area as early as the 1660s since Witsen's information noted above could have dated from this time. Over several centuries, Written Mongol cannot have failed to leave its impress on Buryat, especially in the lexicon where borrowed elements may be identified on the basis of their phonetic and semantic characteristics. As an example, B el'gese- "to sympathize with" must be borrowed from WM eligese- "id.," both because we should expect B *el'gehe- and because this word is typical of literary, religious contexts. Indeed, many of the aberrant forms of Mongol words in Buryat, that is, those which seem to have defied regular sound changes, probably reflect borrowings from Written Mongol.

Such is the case, it may be argued, with B tübhen "level, smooth; peaceful, calm," which corresponds to WM tübsin "id." Had this word developed regularly as a part of the Buryat lexicon, it would have undergone the sound change (2) $s i>\check{s}$ and ended up as B *tübšen. Rather, B tübhen may be explained as a borrowing from WM tübsin that occurred after (2) $s i>\zeta$ and before (3) $s>h$, since it shows the effect of the latter change. Because this borrowing could not have taken place prior to the introduction of Written Mongol, whose earliest possible attested date is the $1660 \mathrm{~s}$, and because the change (3) $s>h$ is known to have existed in the 1720s (Fischer-Messerschmidt), we can establish two further facts of Buryat linguistic history: (1) the change (2) si > s demonstrably occurred before the change (3) $s>h$, as argued above; (2) the change (3) $s>h$ occurred at some point between the $1660 \mathrm{~s}$ and $1720 \mathrm{~s}$.

\section{Russian Loanwords in Buryat}

Due to the fact that they cannot antedate the period of first contacts in the 1620s, the Russian borrowings in Buryat may eventually prove to be one of the most important sources of Buryat linguistic history. The Russian element is devilishly difficult to investigate and no systematic effort to do so has been expended for the present paper. Here only one aspect of this question will be commented upon.

The Buryat sound change (1) $-s>-d$ had certainly occurred by the 1720 s, as it is reflected in the Fischer-Messerschmidt materials. Moreover, as Doerfer pointed out, the change is reflected in the name Fedot, which represents a 
Buryat form of the Russian name Feodosij and which is attested in a Russian document from 1701.31 Furthermore, certain Russian loanwords in Buryat also have this reflex: Rus' $\rightarrow$ orod "Russian," rož' $\rightarrow$ orōd "rye" (Bokhan dial.), peskar' $\rightarrow$ pedger "gudgeon-fish; gobio gobio" (Mukhorshibir dial.). 32 Barring mediation through Siberian Turkic languages, these words could not have been borrowed before the 1620s, so that one might suppose that the change $-s>-d$ occurred after that time. However, several factors should be considered before reaching such a conclusion.

It was already noted above that the change $-s>-d$ is attested in the Middle Mongol period and so could have existed in the dialect base of later Buryat. 33 More significantly, it may be posited that the change $-s>-d$ in Buryat is morphophonemically determined, that is, that the phonetic structure of the Buryat word conforms to a constraint against the occurrence of final $-s$ such that it automatically becomes $-d$. Support of this hypothesis may be found in the false back formations that occur in several Buryat dialects; e.g., Alar bulāt "steel" bulăhĩyě (Acc.) < *bulăsīyè (WM bolod $\leftarrow$ Persian pülāad), pălāt pălāhār (Instr.) < *pălāsār ( $\leftarrow$ Russ. plat). 34 Such cases in which *s $>h$ appears in declined forms could not occur, did not Alar speakers sense that they belonged with cases as ulăt "people" $\sim$ ulăhä (Gen.) < *ulăsäa (WM ulus 世 Turkic $u(u s ̌)-$ in other words, did they not sense that $t(d)$ paradigmatically replaces $s$ in final position.

Thus on the diachronic plane, the change (1) $-s>-d$ probably occurred before the seventeenth century, while on the synchronic plane, the change $-s>-d$ is a structural rule of Buryat that already existed in the seventeenth century.

\section{Conclusions}

On the basis of the preceding discussion, we may now attempt to assign an approximate absolute chronology to each of the sound changes which were aligned in a relative chronology above:
(1) $-s>-d$
(2) $s i>\check{s}$
(3) $s>h$

(4a) $\check{c} / \check{\jmath}>c / j$

(4b) $c / j>s / z$

(5) $\check{c} i / \breve{i}>\check{s} / \check{z}$ occurred before the seventeenth century occurred before (3) (WM tübsin $\rightarrow$ B tübhen) thus before some point in the period $1660 \mathrm{~s}-1720 \mathrm{~s}$ occurred at some point in the period 1660s-1720s (WM tübsin $\rightarrow$ B tübhen)

occurred after the 1620s (B * čagān $\rightarrow$ Barguzin Evenki čagān) and before ( $4 \mathrm{~b})$ ( $\mathrm{B} * c^{*} \bar{o} \rightarrow$ Congol $\left.c \bar{o}\right)$, thus before some point in the period 1680s-1720s

occurred at some point in the period 1680s-1720s (B ${ }^{*} \mathrm{Co} \rightarrow$ Congol $\mathrm{cō}$ )

occurred after (4) but before the 1720s (Messerschmidt), thus toward the end of the period 1680s-1720s

It is significant that (1) and (2) are already attested in Middle Mongol sources and thus need not be peculiarly Buryat at all. The uniquely Buryat features (3)-(5), on the other hand, all occurred over the course of a century, from the 1620s to the $1720 \mathrm{~s}$, and are concentrated in the period from the $1660 \mathrm{~s}$ 
to the 1720s. Prior to this cluster of sound changes, then, the special character of Buryat phonology had not yet taken shape, so that the dialects spoken in the Sis-Baikal area differed but little from other dialects of the central Mongol group.

\section{Notes}

1. Throughout this paper, $s, \check{c}, \breve{j}$, are used for these sounds before vowels other than $i$, while si, $\ddot{e} i$, $j i$, are used for the latter environment. Abbreviations used are: WM $=$ Written Mongol (F. D. Lessing, Mongolian-English Dictionary, Berkeley and Los Angeles 1960), B = Buryat (K. M. Čeremisov, Burjatskomusskij slovar', Moscow 1973).

2. Orily the second edition of 1705 is available to me; cf. Volume II, p. 668. Although Witsen spent three years in the Muscovy state (1664-1667), where he consulted many of the Russian sources which he used for this compilation, he also continued to receive information in Holland from his Russian correspondents, as well as from traveling Dutchmen, for the next thirty-five years--thus, it is not possible to date this mention precisely; cf. E. P. Zinner, Sibir' $v$ izvestijakh Zapadnoevropejskikh putešestvennikov i učenykh XVIII veka, 1968, pp. 10-35.

3. The basic monograph on this subject is now C. B. Cydendambaev, Burjatskie istoričeskie khroniki i rodoslovnye. Istoriko-lingvističeskoe issledovanie, Ulan-Ude 1972 (cf. the review by Lajos Bese, Acta Orient. Hung. 31 (1977), pp. 391-394). Here may be found a complete survey of Buryat historical chronicles and genealogical tables, as well as an exhaustive examination of the language of such texts. Other groups of texts from this area include: grammatical treatises and dictionaries (e.g., cf. the remarks of P. B. Baldanžapov, Jirükenü tolta-yin tayilburi. Mongol'skoe grammatičeskoe sočinenie XVIII veka, UlanUde 1962, pp. 16-17; also R.Ye. Pubaev, "The Tibeto-Mongolian dictionary compiled by the Aga Buryat, Galsan Jimba Tuguldorov, of the Khuatsai clan," Mongolia Society Bulletin 10:2 (1971), pp. 64-71); legal codes (cf. B. D. Cibikov, Obycnoe pravo selenginskikh burjat, Ulan-Ude 1970) and official documents (cf.

Cydendambaev, op. cit., pp. 555-569; Rintchen, "À propos d'une pièce de chancellerie bouriate du XIX siècle," in Studies in General and Oriental Linguistics, Tokyo 1970, pp. 500-504); popular and religious texts (cf. N. Poppe, "An essay in Mongolian on medicinal waters," Asia Major 6 (1957), pp. 99-105; $i d$., "A Buriat literary source of the XIX century on shamanism," in Traditions religieuses et para-religieuses des peuples altaïques, Paris 1972, pp. 109-113; $i d .$, "Opisanie mongol'skikh 'šamanskikh' rukopisej Instituta vostokovedenija," Zapiski Instituta vostokovedenija I (1932), pp. 151-200), story cycles of Indian origin (cf. C. Damdinsuren, "Burjatskij pereskaz Ramajany," in Issledovanija po vostornoj filologii, Moscow 1974, pp. 64-88; N. 0. Sharakshinova, "Les contes du cadavre ensorcelé chez les Bouriates," Acta Orient. Hung. 16 (1963), pp. 45-54; E. V. Barannikova, "Simvolika belogo cveta v burjatskikh volšebnykh skazkakh," in Filologięeskie zapiski, Leningrad 1973, pp. 103-118), and the very important Buryat copies of the Geser epic (cf. Rintchen, "En marge du culte de Guesser Khan en Mongolie," Joumal de la Société Finno-Ougrienne 60:4 (1958), 51 pp.; A. Ulanov, "Burjatskaja unginskaja versija 'Gesera, '" in Trudy XXV. Meždunarodnogo Kongressa Vostokovedov, III, Moscow 1963, pp. 252-257; C. B. Cydendambaev, "On the language of the Mongol and Buriat versions of the Geser epic," in Mongolian Studies, Budapest 1970, pp. 565-579; L. Lôrincz, "GeserVarianten in Ulan-Ude, Ulan-Bator und Leningrad," Acta Orient. Hung. 25 (1972), 
pp. 175-190; id., "'Khurin Altaj' i 'Erensej,'" in Issledovanija po vostočnoj filologii, Moscow 1974, pp. 119-125).

4. See my "Two eighteenth century Buryat glossaries," Mongolian Studies 3, (1976), pp. 53-82.

5. In my study cited in the previous note, I erred in stating (p. 57) that Fischer represented $s$ by both $\int$ and $s \int$; rather, in German orthography, $\int$ always represents $z$ and $s \int$ always stands for $s$ (ss). It is a pleasure to acknowledge that my honored teacher, Denis Sinor, brought this error to my attention.

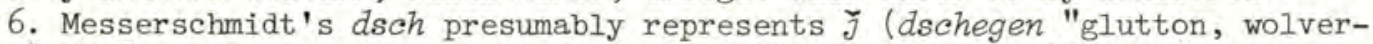
ine," WM Jegegen, as against B zēgen; dschebbön "trout," WM Jebege "Siberian salmon, lenok"), but then one must wonder why he should record $y$ where Buryat has $z$ and $z$ where Buryat has $\check{z}$. This is not clear to me.

7. G. Doerfer, in Orientalistische Literaturzeitung 64 (1969), cc. 506-507, on the basis of the Pallas glossary, had supposed that the Buryat changes of $s, \check{c}, \breve{y}$, occurred during the eighteenth century. G. Kara, "Le glossaire yakoute de Witsen," Acta Orient. Hung. 25 (1972), p. 433, accepts Doerfer's view but points out that these changes are already present in the Fischer glossary.

8. Cf. N. Poppe, Introduction to Mongolian Comparative Studies (Helsinki, 1955) [Mémoires de Za Société Finno-Ougrienne 110], pp. 22-23; G. Sanžeev, Sravnitel'naja grammatika mongol'skikh jazykov, I, Moscow 1953, pp. 42, 46-55; G. Doerfer, "Klassifikation und Verbreitung der mongolischen Sprachen," in Handbuch der Orientalistik, V/2. Mongolistik, Leiden/Köln 1964, pp. 42-43, 4647; N. Poppe, "Die burjätischen Mundarten," Mémoires de Za Société EinnoOugrienne 67 (1933), pp. 331-335; D. A. Alekseev, "Dialekty burjat-mongol'skogo jazyka," Učenye zapiski Leningradskogo gosudarstvennogo universiteta 1949, no. 98, pp. 161-202.

9. Cf. B. V. Matkheev, "Očerki ekhirit-bulagatskogo govora," in Issledovanie burjatskikh govorov, II, Ulan-Ude 1968, pp. 3-46; M. P. Khomonov, "Bokhanskij govor," in Issledovanie burjatskikh govorov, I, Ulan-Ude 1965, pp. 35-70; E. R. Radnaev, "Barguzinskij govor," in Issledovanie, I, pp. 70-107; A. G. Mitroškina, "Govor kačugskikh (verkholenskikh) burjat," in Issledovanie, II, pp. 47-73; N. Poppe, Alarskij govor, I-II, Leningrad 1930-1931; I. D. Buraev, "Nekotorye fonetičeskie osobennosti govora alaro-unginskikh burjat," in Issledovanie, II, pp. 117-135; C. B. Cydendambaev, "Kratkaja kharakteristika govora kudarinskikh burjat," Kratkie soobకrenija Instituta narodov Azii 1964, no. 83, pp. 57-68; M. A. Castrén, Versuch einer burjätischen Sprachlehre nebst kurzem Wörterverzeichnis, ed. A. Schiefner, St. Petersburg 1857; G. D. Sanžeev, Fonetičeskie osobennosti govora nižneudinskikh burjat, Leningrad 1930; D. A. Abašeev, Tunkinskij govor," in Issledovanie, I, pp. 3-34; C. B. Cydendambaev, "K itogam ekspedicionnogo izučenija govorov dobajkal'skikh burjat," in Issledovanie, II, pp. $164-175$.

10. Cf. A. D. Rudnev, Khori-burjatskij govor, I-III, St. Petersburg 1913-1914; L. Bese, "Contributions to the Khori-Buriat subdialect of Ivolga," Acta Orient. Hung. 15 (1962), pp. 15-21; id., "Ob affrikatakh khorinskogo dialekta," Kratkie soob̌renija Instituta narodov Azii 1964, no. 83, pp. 46-48; N. Poppe, Zametki o govore aginskikh burjat, Leningrad 1932; L. D. Šgdarov, "0 nekotorykh jazykovykh osobennostjakh tungujskikh i aginskikh burjat i stepeni ikh otraženija v literaturnom jazyke," in Issledovanie, II, pp. 154-163.

11. Cf. N. Poppe, "tber einige Besonderheiten des Tsongol-Dialektes," Zentralasiatische Studien 5 (1971), pp. 145-155; I. D. Buraev, "Sartul'skij govor," in Issledovanie, I, pp. 108-150; C. B. Budaev, "Congol'skif govor," in 
Issledovanie, I, pp. 151-186; C. B. Budaev, "Izmenenija v leksike i frazeologii congol'skogo govora," in Issledovanie, II, pp. 136-153; N. Poppe, "Skizze der Phonetik des Bargu-Burjätischen," Asia Major 7 (1932), pp. 307-378.

12. Cf. W. Heissig, "A Mongolian source to the Lamaist suppression of shamanism in the seventeenth century," Anthropos 48 (1953), pp. 506-507; Poppe, "Uber einige Besonderheiten des Tsongol-Dialektes," p. 145.

13. Cf. Poppe, ibid., pp. 146-147.

14. Ibid., p. 147 .

15. Cf. N. Poppe, Grommatika burjat-mongol'skogo jazyka, Moscow and Leningrad 1938, p. 181. The enclitic sō, which does not observe vowel harmony, should not be confused with the terminative suffix . cara, found in Buryat dialects as $. s \bar{a} / . s \bar{e} / . s \bar{o} / . s \bar{o} ;$ cf. ibid., p. 130, and Poppe, Introduction to Mongolian Comparative Studies, p. 206.

16. The etymology of sō is still somewhat problematic. Rudnev, Khoriburjatskij govor, I, pp. Ix-lxi, communicated Ramstedt's opinion that sö derives from *dosō from *dočō, which is etymologically related to dotona "inner, within," dotur "inner." G. J. Ramstedt, Einfühming in die altaische Sprachwissenschaft, II, Helsinki, 1952 [Mémoires de la Société Finno-Ougrienne 104:2], pp. 52-53, derives B sō from *dočā, parallel to Kalmyk dotā "inner," by a special development. Poppe, Introduction to Mongolian Comparative Studies, pp. 206-207, says that $s \bar{o}$ "is an abbreviation of dosō zosō < *dočara *dotara 'within,' cf. Mo. dotoradu 'inner,' Kh. dotōda id., cf. the analogous form Mo. radaradu 'outer,' Kh. qad̄̄ 'outside,' Bur. gazā id." Although sō ought to be an abbreviation of some Form whose root is common to that of dotona, dotura and *dotara (Kalmyk!), it cannot have developed from *dočara, which could only have become Buryat *doča $>* \bar{c} \bar{a}>* s \bar{a}$. Rather, so is a regular development of *co < *čura< *dočura, and the latter form contains an element *-ču- that is not otherwise noted in the derivational morphology of adverbials of this nature.

17. Some aspects of the Mongol loanwords in South Siberian Turkic have been treated in N. Poppe's "Uber einige Vokalentsprechungen in mongolischen Lehnwörtern im Tuvinischen," Zeitschrift der Deutschen Morgenländischen GeselZschaft 118 (1968), pp. 113-123, and "On some vowel correspondences in Mongolian loan words in Turkic," Central Asiatic Joumal 13 (1969), pp. 207-214, while Hasan Eren, "Sibirya Türk Dillerinde Moğol Unsurlar," Türk Dili Belleten 14-15 (1950), pp. 35-43, merely extracts, without consequence, the Siberian etymologies of B.Ja. Vladimircov, "Tureckie elementy $v$ mongol'skom jazyke," Zapiski vostočnago otdelenija Imperatorskago Russkago arkheologičeskago obščestva 20 (1910), pp. 153-184. The Buryat borrowings in the language of the Tofalars, a small group who live intermixed with the Buryats in the Oka area and who speak a language most closely related to Tuva and Tời, have been studied by V. I. Rassadin, but these loanwords already show the modern state of Buryat; cf. "Burjatskie leksičeskie zaimstvovanija v tofalarskom jazyke," in Issledovanie burjatskikh govorov, II, pp. 187-191; see the same scholar's "O tjurkizmakh $\checkmark$ burjatskom jazyke," in $K$ izučeniju burjatskogo jazyka, Ulan-Ude 1969, pp. 129-134, and L. D. Šagdarov and V. I. Rassadin, "Ob upotreblenii tofalarami burjatskogo jazyka," in Issledovanie, II, pp. 176-186. The following contact studies are devoid of methodological value: A. A. Bulakaeva-Barannikova, "Sopostavitel'nye materialy po leksike sovremennogo tatarskogo i burjatmongol'skogo jazykov," in Sbornik trudov po filologii, Ulan-Ude 1958, pp. 157175; P. P. Baraškov, "O mongolo-burjatskikh i jakutskikh jazykovykh zvjazjakh," in ibid., pp. 176-206; A. A. Bulakaeva-Barannikova," Obščie slova v leksike sovremennogo kirgizskogo i burjatskogo jazykov," Učenye zapiski Burjatskogo 
gosudarstvennogo pedagogireskogo Instituta imena D. Banzarova 16 (1958), pp. 113-143; id., "Turecko-burjatskie jazykovye paralleli," ibid. 23 (1961), pp. 237-266.

18. Mongolische Elemente in der jakutischen Sprache, Warsaw 1962 [Prace Orientalistyczne 10].

19. Ibid., pp. 45-48.

20. Ibid., pp. 123-126.

21. I. A. Podgorbunskij, Russko-mongolo-burjatskij slovar', Irkutsk 1909, p. 257; E. K. Pekarskij, Slovar' jakutskogo jazyka, I, St. Petersburg 1907 , p. 911 .

22. This is hardly the place to broach the complex problem of the southern origin of the Yaquts which, since the fundamental researches of A. P. Okladnikov, Yakutia Before its Incorporation into the Russian State, Montreal and London 1970 [Anthropology of the North: Translations from Russian Sources, 8], has been localized in the Sis-Baikal region where the Buryats evolved, and where the Mongol-Yaqut contacts presumably occurred prior to the northern migration of the Yaquts. Nonetheless, I should like to recall two facts that somewhat obscure this picture. First, on the basis of his study of the geographical and demographic distribution of Siberian peoples in the seventeenth century, B. 0 . Dolgikh, Rodovoj i plemennoj sostav narodov Sibiri v XVII veke, Moscow 1960, was able to complete a map (between pp. 614 and 615) which shows a group of "Korintsy" (= Khori) and "Daury" settled in the region northeast of Yakutsk. This important proof of probably Mongol elements co-existing with the Yaquts as late as the seventeenth century was first pointed out by G. Kara, "Le glossaire yakoute de Witsen," p. 432. Second, it may be recalled that one of the components of the Yaqut people were the Khoro who, according to Yaqut legends, spoke in the special xoro tıla "Khori language"; cf. G. U. Ergis, Istoriěeskie predanija $i$ rasskazy jakutov, I, Moscow and Leningrad 1960, pp. 18, 100-103, $244-245,298$. This suggests the presence in the north of a Mongol-speaking people, specifically the Khori who also took part in the formation of the Buryats, over an indeterminable period prior to and perhaps during the seventeenth century.

23. These examples are cited by G. Doerfer in Orientalistische Literaturaeitung 58 (1963), c. 506; cf. Kałużyński, op. cit., pp. 124-125.

24. Cf. Kara, "Le glossaire yakoute de Witsen," and note 2 above.

25. That layer (a) is older than layer (b) was already the conclusion reached by N. Poppe, "Das Jakutische," Philologiae Turcicae Fundamenta, I, Wiesbaden 1959 , p. 683, and accepted by Kara, "Le glossaire yakoute de Witsen," p. 434. 26. On the essentially Buryat character of both layers of loanwords in Yaqut I agree with Doerfer, in Orientalistische Literaturzeitung 58 (1963), cc. 506507 , although my conclusions concerning the chronology of Buryat sound changes differ from his.

27. Cf. the recent sketch of A. S. Šubin, Kratkij očerk etniěeskoj istorii evenkov Zabajkal'ja (XVII-XX vv.), Ulan-Ude 1973.

28. Cf. N. Poppe, Materialy dija issledovanija tungusskogo jazyka. Narečie barguzinskikh tungusov, Leningrad 1927; W. Kotwicz, "Le dialecte tongous de Bargouzine (matériaux recueillis par D. Rinčino)," Rocznik Orientalistyczny 16 (1950), pp. 315-326; the work of V. A. Gorcevskaja, Kharakteristika govora barguzinskikh evenkov, Moscow and Leningrad 1936, is based solely on the materials of Poppe.

29. This example was brought to my attention by Professor Poppe during his 
comments on my paper at the Bellingham conference, for which I wish to express my gratitude at this time. To my regret, I have not otherwise investigated the Buryat loanwords in Evenki.

30. Cf. Poppe, Materialy dlja issledovanija tungusskogo jazyka, p. 59.

31. Cf. Doerfer, Oriens 18-19 (1965-1966), p. 434; G. N. Rumjancev and S. B. Okun', Sbornik dokumentov po istorii Burjatii. XVII vek, I, Ulan-Ude 1960, p. 422. Both Sanžeev, Sravnitel'naja gramatika mongol'skikh jazykov, I, p. 9, and Doerfer, in Orientalistische Literaturzeitung 58 (1963), c. 506, interpret the Mongol data in such Russian documents as Buryat. In the light of my new conclusions concerning the chronology of Buryat sound changes, I am inclined to accept their view as the most probable, but have not yet examined this material in detail; cf. my "Two eighteenth century Buryat glossaries," p. 61 [on p. 82 , n. 33, I have wrongly criticized a statement of Sanžeev, which I simply misconstrued!J; also cf. the view of Kara, "Le glossaire yakoute de Witsen," p. 433.

32. Cf. M. P. Khomonov, "Bokhanskij govor," in Issledovanie, I, p. 64; T. A. Bertagaev, $K$ issledovaniju leksiki mongol'skikh jazykov, Ulan-Ude 1961, p. 77 [nürai pedger "a fish of the carp species, a karas'-fish," but see G. U. Lindberg and A. S. Gerd, Slovar' nazvanij presnovodnykh my SSSR, Leningrad 1972, pp. 157-159, for this species].

33. Cf. my remarks in Mongolian Studies 3 (1976), pp. 123-125, and in "Turkic loanwords in Mongol, I. The treatment of non-initial s, $z$, ̌̌, Asiatic Journal 23 (1979), in press.

34. Cf. Poppe, Alarskij govor, p. 25. 


\title{
THE ACTIVITIES OF THE MPR STATE COMMITTEE FOR TERMINOLOGY: BASIC PRINCIPLES IN FORMULATING NEW VOCABULARY
}

\author{
Hisao Kimura \\ Asia University, Tokyo
}

Under the provisions of the Japanese-Mongolian Treaty for Cultural Cooperation, a research team of Asia University was invited by the MPR Academy of Sciences to visit Mongolia in September 1977. The research theme of the group was "A Study of Mongolia's Modernization." My task was to investigate modernization in the linguistic field of terminology or neologisms.

As a result of the revolution in 1921, the Mongolian People's Republic (MPR) became the second socialist state in world history. Since then the MPR has exerted great efforts in building a modern socialist nation. It has been particularly successful in the educational field in the three decades since the second world war.

In spite of much turmoil immediately following the revolution in 1921 , the Mongolian government mapped out plans for the national development of education. One problem that blocked the success of the plan was the lack of necessary vocabulary due largely to the traditional nomadic background of the Mongols. It was therefore imperative to create or standardize academic terms essential to the modern development of education, particularly for ideological education.

To meet this necessity, efforts were made to create new terms by translating or adopting foreign terms. To promote and coordinate this task, the Mongolian government established a Committee for Terminology under the State Committee of Sciences (to become the Academy of Sciences in 1961). At the first Great People's Khural, held in November 1924, Jamyan, chairman of the Committee of Sciences reported: "Almost everyone is inventing new words or new terms as they please. To protect the purity of the Mongolian language and to meet a rising demand of the times, we have set up some ten specialized subcommittees and assigned to them the scientific study of needed new academic terms."

In 1930 a Translation Committee for Political and Economic Terms was organized under the Committee on Propaganda and Education of the Central Committee of the Mongolian People's Revolutionary Party (MPRP). This translation committee soon published a Russian-Mongolian dictionary for political and economic terms containing some 600 ideological terms from Marxist-Leninist works. A Russian-Latin-Mongolian botanical dictionary was published in 1931. In 1932 an Academic Terms Committee was established within the Department of Philology and Phonetics of the MPR State Committee of Sciences. This committee later became the State Committee for Terminology. In 1935 this committee published a Russian-Mongolian dictionary of mathematical terms and a Russian-Mongolian dictionary of geographical and meteorological terms. In 1937 it published a Russian-Mongolian dictionary for chemical terms, a Russian-Mongolian dictionary for physical terms, and in 1965 it published a Russian-Mongolian dictionary of 
academic terms. Since 1959, the State Committee for Terminology has been publishing a quarterly periodical, "Supplementary Volume on Academic Terms," to announce newly adopted industrial and agricultural terms. To publicize and popularize new terms among the common people, the state committee publishes a quarterly, "News of the State Committe for Terminology."

It has published to date three volumes entitled "Collection of Academic Terms," containing more than 30,000 terms. The Political Bureau of the MPRP Central Committee adopted a resolution in 1963 entitled, "Work of the Language and Literature Committee of the MPR Academy of Sciences." The resolution directed that in formulating or standardizing academic terms, the State Committee for Terminology should adhere to the principle of motivating and assisting the Mongolian people to understand the best scientific, cultural and technical achievements in the world, of facilitating the students' studies, and of continually enriching the vocabulary of the Mongolian language. The State Committee should constantly investigate actual usage of new terms in the society and if necessary, correct and improve them on the basis of public opinion. This resolution continues to be the fundamental guiding policy of the committee today.

On September 12-13, 1977, I had the opportunity of interviewing Professor Lubsandendeb, president of the Language and Literature Institute of the Academy of Sciences in Ulaanbaatar and concurrently chairman of the State Committee for Terminology. I also interviewed Professor Lubsanjab, dean of the Literature Department of the Mongolian State University and concurrently member of the State Committee for Terminology. They explained how new academic terms are formulated in the Mongolian People's Republic. The following remarks contain the gist of their statements and several articles written by Mongolian scholars on the subject of terminology.

There is presently a Department of Academic Terms within the Language and Literature Institute of the Academy of Sciences. Apart from this, there is the State Committee for Terminology consisting of nine scholars appointed by the central government. All government offices and affiliated agencies are required to propose new terms they desire to incorporate in their various activities. They do so in cooperation with the above-mentioned Department of Academic Terms. The proposals drafted are then submitted to the MPR State Committee for Terminology. Several subcommittees of specialists within the State Committee then study the proposals with the assistance of other specialists from various fields. If necessary, the subcommittee amends the proposed draft of terms and, after approving them, the State Committee for Terminology announces them officially. official announcements of new terms are incorporated in the quarterly magazine published by the State Committee. From time to time, the State Committee also publishes dictionaries or collections of terms in various industrial, scientific, and cultural fields. The State Committee for Terminology strictly observes certain fundamental principles in creating new academic terms so that the new terms are formulated on a scientific basis; they should be nationalistic, systematic, standardized and unifying.

The Mongols formulate new terms by borrowing from Indo-European languages. Almost all new or modern words come from or through the Russian language. This is an inevitable consequence under present circumstances. There is, however, a fundamental policy that the new terms should be derived from basic Mongolian 
vocabulary as much as possible.

1. New words or terms are taken from classical Mongolian literary words or from local dialects. They include the names of animals, plants, minerals and social phenomena. Example: ekh 'mother' + bari- 'to restore' + suffix -gch $=$ ekh barigch 'midwife.'

2. New words or terms are derived from old Mongolian literary words or local dialects by giving them new meanings. Examples: old word nökhör 'friend' now means comrade; old word tsakhilgaan 'lightning' now means electricity, as in tsakhilgaan emneleg 'electric medical treatment'; old word tengri 'heaven' now means god.

3. New terms are formed by combining old Mongolian words in both subordinative and coordinative combinations. Examples: old words orlogo 'income' + zarlag 'expenditure' = orlogo zarlaga 'budget'; old words möljikh 'pluck' + yus 'system' = möljikh yus 'exploitation.'

4. New terms are derived by translating the meaning of foreign terms. Examples: old words gerel 'flash light' + zurag 'image' = gerel zurag 'photograph'; old words nevterkhii 'detailed' + tol' 'dictionary' = nevterkhii tol' 'encyclopedia; old words surga- 'to teach' + khömü̈̈jü̈̈lekh 'to raise, to bring up' + ukhaan 'knowledge' = surgan khömü̈̈jü̈̈̈lekh ukhaan 'pedagogy.'

5. New terms are made by a simulated translation of foreign terms. Examples: us 'water' + törö- 'to give birth to' + suffix -gch 'element' = us törögch 'hydrogen'; khüchil 'sourness' + törö- 'to give birth to' + suffix -gch 'element' = khüchil törögch 'oxygen.'

6. New words or terms are created by adding suffixes to old Mongolian words. Examples: old word ukhuula 'to propagate' + suffix gch 'element or person' = ukhuulagch 'agitator.'

7. Categories of foreign borrowings:

a. Foreign words or terms adopted with some phonological changes. Examples: oktyabri 'October'; avtobus 'bus'; tsirk 'circus.'

b. Foreign borrowings with explanatory term. Examples: nisekh 'flying' + ongots 'ship' = nisekh ongots 'airplane'; niigem 'social' + juram 'system' = niigem juram 'socialism.'

c. Foreign borrowings with double meanings are translated differently. Examples: the Russian term fizicheskaya nauka becomes Mongolian fizikiyn shinjlekh ukhaan 'physical science.' The Russian term fizicheskiy tmud becomes bieiin 'body' + khödölmor 'labor' = physical labor.

d. Terms are created by combining foreign borrowings and Mongolian words. Example: khushuuch 'vanguard leader' + general = major general; kino 'cinema' + zurag 'picture' = movie; zuragtai 'with picture' + radio = television.

As one may see from the above examples, the neological technique is ingeniously developed with the priority given to the basic Mongolian vocabulary. Only when deemed unavoidable are foreign borrowings or terms adopted. Even in adopting foreign terms, it is done in a consistent, sophisticated manner. That is to say, instead of simply adopting a Russian word or term as is, the item in question is traced back to its original meaning or original form in Greek or Latin. Then it is translated into Mongolian directly from its original meaning or it is adapted in its original form from the Greek and Latin.

In spite of the fact that Russian is presently playing a leading role in the development of a modern Mongolian vocabulary, it appears that deliberate, studied efforts are being made to avoid borrowing terms directly from Russian. Foreign 
borrowings of Greek and Latin origin adopted into Mongolian through Russian are defined by Mongolian linguists as international words. It is noteworthy that the number of Mongolian words borrowed directly from pure native Russian is far less than the number of so-called international words or terms. Mongolian linguists are very aware of this phenomenon. They welcome the increased use of international terms in the political, economic, scientific and cultural fields to enrich the Mongolian vocabulary. Nevertheless, in order to avoid confusion in the practical field of technical or academic terms, these linguists emphasize the absolute priority and importance of formulating terms from basic native Mongolian vocabulary.

After going through dozens of articles written by the Mongolian linguists on the subject, I have come away with the impression that all of them shared a firm and profound nationalistic respect for Mongolia's traditional culture, particularly of its language. Today the MPR is conducting advanced education and academic research on its own language. It is true that a modern Mongolian vocabulary is still in the process of being developed, but there can be no doubt that the Mongolian vocabulary has already been improved and modernized to the extent that higher education and academic research can be conducted in the language.

It is instructive to compare Mongolia's experience with that of other modernizing countries. In Japan such words as society, individual, freedom, rights, philosophy, insurance, and company had not been formulated until the Meiji era (1868-1912). Although Japan had a long tradition in the use of Chinese characters $(k a n j i)$, it was not an easy task to create precise or apt words or terms expressing certain abstract concepts because many such expressions had never existed in Japan. Traditional Mongolia, too, lacked many abstract expressions. Mongolia, therefore, also experienced great difficulties in developing abstract terms. In spite of the differences in the political and social systems, I can see many common problems and similarities in the experience of Mongolia and Meiji Japan in the rapid adoption of foreign culture.

The MPR State Committee for Terminology is playing a leading role as a driving force in formulating, standardizing and popularizing new terms in Mongolia in a comparatively short period of time. Judging from its activities in the last half century, the role and achievements of this committee in promoting the modernization of Mongolia should be highly esteemed and commended. 


\section{JURCHEN AND MONGOLIAN}

\section{Nicholas Poppe}

Seattle

Jurchen (Jürčen) is a language very close to Manchu and can be regarded either as the older form of Manchu or as a dialect very close to old Manchu. ${ }^{1}$ The speakers of Jurchen appeared in history in A.D. 1115, and their dynasty bearing the name of Chin ruled over Northern China until 1234.2 The oldest available monument of the Jurchen language is an inscription of 1185 which was followed by a number of other steles, but the most important source is the collection of materials, i.e. documents and a glossary, known as Hua-i $i-y \ddot{u}, 3$ which contains, inter alia, a petition of 1526.4

Jurchen has been studied little. The first investigation of Jurchen was published by Grube 5 which remained the only one until the appearance of Ligeti's articles. 6 There is also a brief description of Jurchen by Menges. 7 The most recent edition of Jurchen linguistic material is that by Kiyose cited in note 3. The present article is based on it.

As mentioned above, the Jurchen appeared in history in the twelfth century, i.e. at the end of the Ancient Mongolian period or at the beginning of the Middle Mongolian period. 8 However, their contacts with the Mongols or the ancestors of the latter began at a still earlier time. As it will be seen below, some Mongolian elements in Jurchen go back to Ancient Mongolian.

Ligeti has discussed the old Mongolian elements in Manchu and found that a number of such words already occurred in Jurchen.9 It is true there are AMo loan words in Manchu which, for chronological reasons, cannot be regarded as direct borrowings from Mongolian but must have been inherited from Jurchen.

Being close to Manchu, Jurchen has, however, preserved many features which are considerably older than the respective developments in Manchu. Thus Jurchen still had $t$ before $* i$, whereas in Manchu the affricate $\check{c}$ corresponds, e.g., $\mathrm{J} 805^{10}$ tatibum 'to study' = Ma tačibu- 'to teach.'ll Some words in Jurchen have preserved the second syllable which has disappeared in Manchu, e.g., J 209 $f a^{\prime} a$ 'window' = Ma $f a$ id. ${ }^{12}$ etc. Consequently, one should expect Jurchen, a language much more archaic than Manchu, to be an important source for the study of Ancient Mongolian. Indeed, as it will be seen shortly, Jurchen has preserved a number of the oldest reconstructable forms of Mongolian words.

Before we proceed to the discussion of AMo loan words in Jurchen, let it be said that the Mong. elements in Jurchen can be divided into two main groups. The first group is composed of such words which lack features characteristic of any particular stage of language development. Thus, J naracu 'the brother of the mother'l3 is a Written Mongolian form, cf. Mo naaacu 'maternal uncle' which is identical with MMo naracu id., 14 but, on the other hand, almost identical with Ord naga't'si 'maternal relative.'15' Another example is J Jasa- 'to rule, order, decree'16 which is identical with Mo and MMo Jasa-, 17 and Ord DŽasa- (phonetically the same as yasa-id.).18 If it had been unknown that the 
$J$ forms in question are attested in the $J$ section of the Hua-i $i$-yü, the words in question could not be regarded as old borrowings from Mongolian. It goes without saying that such J words as irge-n 'people,' arki 'liquor,' Jasa- 'to rule,' naracu 'maternal uncle,' and xurixan 'lamb'l' do not contribute anything to historical phonology of Mongolian, and are important only as proof that they existed at that time in the forms attested in the Hua-i $i-y \ddot{u}$.

The other group of Mong loan words in Jurchen comprises words which display features characteristic of particular periods of language history. Thus, $J$ xaliu 'sea otter'20 is certainly a MMo form, cf. MMo qali'un 'beaver,'2l Mo qalirun 'otter' etc. 'This is a rather new form which might have penetrated into Jurchen no earlier than in the twelfth or thirteenth century. Another MMo form is J 170 ajix morin 'stallion,' cf. Mo ajirga, MMo ajimra id.22 As for the AMo form of this word, it is kadirga attested as a borrowing in Solon.23 A MMo form is also J 457 dauli- in daulimei 'to snatch,' cf. SH da'uli- 'to plunder, capture, '24 H da'uli- 'to plunder,'25 L daulin 'enemy raid, '26 Mo taruli- 'to chase, attack, seize.'27

The above examples demonstrate that Jurchen was under Mong influence both in AMo and MMo periods. No wonder that Manchu, the continuation of Jurchen or its closest relative, has also many old and new Mong loan words. It is surprising, however, that Mongolian does not have borrowings which could be regarded with certainty as taken from Jurchen, although one would have expected to find such loan words in view of Jurchen's importance at a time when the consolidation of the Mongolian tribes was in its very initial stage. This might be another proof that the reason for borrowing of words is not the political or cultural inferiority of the speakers of the borrowing language. The most convincing other examples are Russian and Persian, both of them possessing a large number of Turkic loan words, notwithstanding the fact that both of them were culturally and otherwise considerably superior to the Turkic tribes.

After these preliminary remarks, we proceed to the AMo loan words in Jurchen.

\section{Presemation of AMo * $i$ in the second syllable}

In many cases the original ${ }^{*} i$ in the second syllable was assimilated to the vowel of the initial syllable as early as in Ancient Mongolian.28 $\mathrm{Cf}$. Mo gedesün < AMo *gedelsün *gedilsün < *güdilsün 'intestines' but Mo gü犭ige < AMo *güdige, cf. Ev gudire 'peritoneum'29< AMo; Mo gede < AMo *gede * gedi 'occiput, nape,' cf. Mo gĕJige <AMo *gedikē 'queue. '30

Jurchen has preserved AMo * $i$ in the following words: J 483 medige < AMo *medige 'tidings,' cf. Mo medege < *medige 'information,'31 J 228 hudila < AMo hudila < AMo *kudirkā 'crupper' > Mo qudurga id.32 Although Middle Turkic has only quourrun 'crupper, 133 i.e. an assimilated form, Ancient Turkic may have had *qudïrÿn 'crupper.'

\section{Preservation of AMo *d before *i}

In Ancient Mongolian * $d$ before * $i$ was still preserved, cf. AMo *güdige 'stomach' > Ev gudire 'peritoneum.' 34

Jurchen has preserved several AMo forms with *d before $i$, cf. J 383, 489, 756 dirgala- 'to take pleasure, enjoy, be cheerful' < AMo *dirga- > Mo Jirga'to be happy, be joyful,' cf. Yak sïrrā- 'to enjoy food' (a later borrowing from Mong); 35 J 483 medige 'tidings' < AMo *medige > Mo medege, Kh mèdè 
'information,' cf. the younger loan word Ma medege $\sim$ medexe 'information, news' id.;36 J 228 hudila 'crupper' < AMo *kudirkā id.,37 Ma qudurran id. and Ev kudurga id. being new borrowings from Mong. 38

However, there occur also two typical MMo forms with $\tilde{j}<* d$ which are to be regarded as later borrowings taken at the end of the Jurchen period. These are

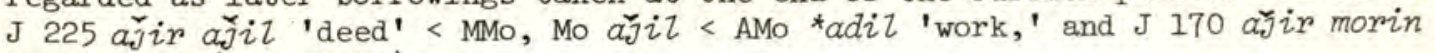
'stallion' (see above).

\section{Preservation of AMo *f-} Ancient Mongolian had the strong stop ${ }^{*} p$ or the bilabial voiceless fricative
${ }^{\phi}$ at the onset of many words. 39 It developed into $h$ in Middle Mongolian, 40 and is still preserved as $x$ in some Mongolian languages.

Jurchen has at least one AMo loan word with $f$-, cf. J 410 fute- in futemei 'to see off' < AMo *püde- (or * $\phi \ddot{u ̈ d e-}$ ) id., MMo (H) hüde- 41 Mo üde-id. This word occurs also in Manchu-Tungus languages, cf. U1 pudeçi- 'to expel ("see off") an evil spirit,' Nan pude- fude-id., Ma fude- 'to see off.' It occurs in the Northern Tungus languages only as a new borrowing from Mongolian, cf. ude-. 42

The other Jurchen word with $f$ - is J 243 fila 'dish,' but this is certainly not an AMo loan word because Mo has bila 'dish, bowl' which is a borrowing from Turkic, cf. Osm, Crm piyalä 'bowl, mug,' Uzb piyala 'tea cup,' Cum piala 'goblet,' Kaz piyala < Pers piyaza. 43 Therefore J fila is to be regarded as a word of Pers origin but borrowed via Turkic together with such words as Ma gindana 'prison' < Pers zindān etc. 44

\section{Initial AMo *k}

The initial * $k$ has developed into $J h / x /$ in most cases both before back and front vowels, cf. J 393 halabi 'to alter' = Ma xala- 'to change, exchange, alter,' Neg kala- 'to replace,' Ud kala- 'to replace, change,' etc.;45 J 467 hendu-' 'to say' = Ma xendu- 'to speak, explain,' Or ken- 'to speak, converse,' etc. ${ }^{46} \mathrm{~J} 508$ hefuli 'abdomen' = Ma xefeli id., Ev kĕbal 'stomach,' cf. Mo kebeli < AMo *kepéli 'belly. 147 on the other hand, there are very few Jurchen words with $k$-.

There are the following AMo loan words with initial $h$ : J 272 hagan (haganni genitive) 'emperor,' cf. Mo qaran, MMo qa'an qān id., cf. Ev kagan etc.; 48 J 92 halgun 'hot' < AMo, cf. Mo qalarun, MMo qala'un id.; J 112 hudila 'crupper' < AMo, cf. Mo qudurga id.; J 336 hulahai niyarma 'burglar' < AMo, cf. Mo qulagai id.; J 258 hutuhan 'cup' < AMo, cf. MMo quduqa, cf. Mu qudura 'pitcher;'49 J $144^{2}$ honi 'sheep' <AMo *konin, MMo Mo qonin id., cf. Ma xonin, Ev konin 'sheep,' Ud xuani 'ram,' etc. 50 < Mong; J huo-Zi-han/xurixan/5i or /quriqan/ < AMo, cf. MMo (H) quxiqan 'lamb, 152 Mo quragan, Bur xurigan id.

An exceptional development $* k->$ Zero is found in J 655 orin 'twenty' which also occurs in Manchu and most Manchu-Tungus languages without a consonant at the onset, the consonant having been preserved only in UI, Or, and Nan. 53 Tsintsius reconstructs a deep velar stop in cases like this. 54

\section{The medial AMo *k}

The medial. ${ }^{*} k$ is likewise represented by $h$ in Jurchen, cf. J 336 andahai (in 
andahai niyarma) 'guest' < AMo *andakai, cf. Mo andagai 'oath, sworn statement,' Kh andgaj id., cf. Ma anda 'friend,' Nan andaxa 'guest,' Neg andaxa 'guest, a good fellow,' all < Mong; 55 J 547 mahila < AMo *makïlai, cf. MMo (Mu) maqalai 'cap,' Kalm maxlā id., Mo malagai id., cf. Mя maxala id. < Mong;56 J 519 turha 'lean' < AMo *turka(n) 'lean, émaciated,' MMo (Mu) turqan id., cf. Ma turxa id. $<$ Mong.

6. Preservation of AMO ${ }^{*}{ }^{*} g-$

Intervocalic * $g$ has been preserved in Mongolian before an original short vowel (strong position), but it has disappeared before an original long vowel (weak position). 57

In Ancient Mongolian $-g$ - was still preserved in all cases. ${ }^{58}$

Jurchen has preserved $-{ }^{*} g-$, cf. J 146 bugu 'deer' < AMo *bugu (strong position) id., Mo buru (cf. Mu buruyin turul 'fawn,' lit. 'the calf of a deer'). Mo bugu id., Kh bug id.; J 92 halgun 'hot' < AMo *kalagün (weak position) > MMo qala'un, Mo qalarun, Mog qaloun id., Dag xalō id.; J 94 dulgan 'warm' < AMo *dulugān < Mo dularan, Kh dulaan id., cf. Ev *dūl- 'to warm,' düli 'warm'; J 93 sergun 'cool' < AMo *serigü̈n > Mo serigün, Kalm serü̈n id. Cf. Ma serguven, Ul seuruli, Nan serguēe id. < Mong; J 137 temge 'camel' < AMo *temegēn, Mo temegen, Kh temee id., cf. Sol temegē, Ma temege id.59 < Mong; J 597 .jegun 'left' (in the glossary incorrectly translated as 'right') < AMo * jegün, Mo Jegün, Kalm zü̈n id. Cf. Ev Jevin 'left,' Neg Jirinidēgde 'left side,' Nan Jeuntu 'left-handed,' possibly all < Mong; J 287 degun 'younger brother' < AMo ${ }^{\prime}$ deg $\overline{\ddot{u}}>$ MMo de' $\ddot{u}$, Dag dew, Mog döw, Mo degü̈̈, Kalm dü id., cf. Ma deo id. < MMo; J 523 badgai 'meal' (probably a genitive) < AMo *budagā 'grain, cereal, millet, gruel' > Mo budara $(n)$, Kh budaa id. Cf. Neg buda 'millet,' Ul 'millet, gruel,' Nan boda 'gruel,' Ma buda

\section{Sylzable- and word-final $r$ in AMo}

The syllable-final $r$ in Mong loan words in Jurchen has been preserved: J 83 erte 'early' < AMo *erte, Mo erte id.; J 483 dirga- 'to take pleasure' < AMo *dirga- > Mo Jirga- 'to be happy, to enjoy'; J 649 durhon 'fourteen' < AMo *dör(in *dör-bēn 'four') + *hon 'ten,' cf. AT on 'ten'; J 648 gorhon 'thirteen' < AMo *gur- (in *gur-bān 'three') + *hon 'ten'; J 843 irge-be 'populace' (acc.) $<$ AMo irge $(n)>$ MMo (Mu), Mo irgen 'people'; J 519 turha 'lean' < AMo *turka(n) $>$ MMo, Mo turqan id.

The word-final $r$ has been preserved only in J 329 nekur 'friend,' cf. Mo nökür, Kalm nökr id., cf. however, J 800 nekulemai 'to keep company,' cf. Mo nökürle- 'to befriend, to be friends with someone.' Otherwise, word-final $r$ has been replaced by $n$ as in all Tungus languages, cf. Ev himgēen 'blessing, benediction' < AMo 'pirügèr. An example in Jurchen is J 187 šinkoan 'falcon' < AMo *sinkor, Mo šongor, Kh šonxor id. This word was borrowed from Jurchen into Manchu, cf. Ma sonqon 'peregrine falcon.'

The substitution of $n$ for $r$ is also found in medial position in $J 641$ ningu

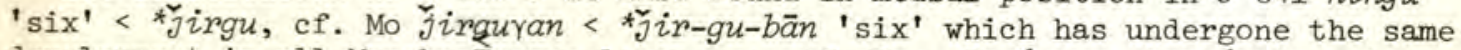
development in all Manchu-Tungus languages, cf. Neg, Ev frumun, Lam frundn, etc. $<$ *yirgur62 < Mong.

It is obvious that $-*_{r}>$ Zero, $-*_{r}>n$, and the preservation of $-*_{r}$ as such date from different times. It is possible that the words with the final $n$ were 
borrowed from Ancient Mongolian, i.e., J šinkoan < AMo *šinkor 'falcon.' The words with final $r$ in Jurchen must have been borrowed later, i.e., from Middle Mongolian, i.e., J nekur 'friend' < MMo. As for nekulemai 'to keep company,' this goes back to *nökürle-, the cluster $r l$ having lost its first component. In $J$ ningu the medial $*_{r}$ has developed into $n / n /$ under the influence of the initial $n$, and was assimilated (velarised) to the following $g$, i.e., *jirgu > ${ }^{*}$ nirgu > ningu/ningu/.

\section{On some Jurchen numerals}

The Jurchen numerals 11 through 19 are of interest for two reasons. First of all, some of their components are of Mongolian origin and second, the numerals in question display a non-Altaic order of components. The Jurchen numerals were investigated for the first time by Laufer, 63 and from the Altaistic point of view by Millèr. 64

The numerals in question are:

J 646 amšo 'eleven' = Ma omšon (in Ma omšon biya 'the llth month')

$\mathrm{J} 647$ Jjirhon 'twelve' = Ma Jorgon (in Jorgon biya 'the 12th month')

J 648 gorhon 'thirteen' < AMo *gur (in *gur-bān) 'three' + *hon 'ten'

J 649 durhon 'fourteen' < AMo *dör (in dör-bēn) 'four' + *hon

J 650 tobohon 'fifteen' < AMo *tabu (in *tabu-n) 'five' + *hon

J 651 nilhun /nirhun/ 'sixteen' < AMo *ỹir (in *yir-gu-bān) 'six' + *hon

J 652 darhon 'seventeen' < AMo *dal (in *dal-u-bān > Mo doluran 'seven' + *hon

J 653 niyuhun 'eighteen' < AMo *nai (in *nai-bān > Mo naiman) 'eight' + *hon

J 654 oniyohon 'nineteen' < J uyun 'nine' + *hon

of these numerals nilhun 'sixteen' is of interest because it has preserved the syllable-final *r (nilhun stands for *nirhun) whereas $J$ ningu 'six' is an assimilated form.

The other interesting form is 652 darhon (probably /dalhon/) 'seventeen.' It corroborates our reconstruction of Mo doluran 'seven' as *dal-u-bān.65

On the other hand, the numerals mentioned are interesting because of the order of the components, namely, the smaller numbers precede the numeral ten as in English or Latin, an order quite unusual in the Altaic languages.

The general conclusion from the above discussion is that Jurchen is an important source for the study of the history of the Mongolian languages in that it has preserved a large body of AMo forms. On the other hand, Mongolian data can be useful for the reconstruction of Jurchen and other Manchu-Tungus forms.

Notes

1. Cf. Johannes Benzing, "Die tungusischen Sprachen: Versuch einer vergleichenden Grammatik," Akademie der Wissenschaften und der Literatur: Abhandlungen der Geistes- und Sozialwissenschaftlichen Klasse, Jahrgang 1955, $\mathrm{Nr}$. 11 (Wiesbaden, 1956), p. 961. Menges tentatively suggested that "Jurchen" might have been a name invented by the Manchus, vide K. H. Menges, "Die Sprache der Jurčen," Handbuch der Orientalistik, Erste Abteilung: Der Nahe und der Mittlere Osten, Fünfter Band: Altaistik, Dritter Teil: Tungusologie (Leiden/Köln, 1968), p. 246. This contradicts, however, the fact that the name "Jurchen" had been known long before the rise of the Manchus; cf. the form Jürcet in the Secret History of A.D. 1240, Erich Haenisch, Wörterbuch zu Manhol un niuca tobca'an 
(Yüan-ch'ao pi-shi), Geheime Geschichte der Mongolen (Wiesbaden, 1962), p. 179. The same name occurs also in Rašid ad-Din's work written in the first decade of the fourteenth century; see Rašĩ ad-Din, Sbomik letopisej, Tom I, kniga vtoraja, Perevod s persidskogo 0. I. Smirnovoj et al. (Moskva-Leningrad, 1952), pp. 76-77.

2. René Grousset, L'empire mongol (=Histoire du monde, Tome VIII,3) (Paris, 1941), p. 292.

3. Gisaburo N. Kiyose, A Study of the Jurchen Language and Script: Reconstruction and Decipherment (Kyoto: Hōritsubunka-sha, 1978), p. 23.

4. Wilhelm Grube, Die Sprache und Schrift der Jucen (Leipzig, 1896), p. 115.

5. Grube, op. cit.

6. L. Ligeti, "Note préliminaire sur le déchiffrement des petits caractères joutchen," AOH 3 (1953), pp. 211-228; "Les inscriptions djurtchen de Tyr: la formule om mani padme hwo," AOH 12 (1961), pp. 5-26; "Les anciens éléments mongols dans le mandchou," $\dot{A} O H 10$ (1960), pp. 231-248.

7. See note 1 .

8. On Middle Mongolian see N. Poppe, "Das Mittelmongolische," Handbuch der Orientalistik, Erste Abteilung, Fünfter Band, Zweiter Teil: Mongolistik (Leiden/ Köln, 1964), pp. 96-103.

9. Ligeti, "Anciens éléments," pp. 231-248.

10. Abbreviations:

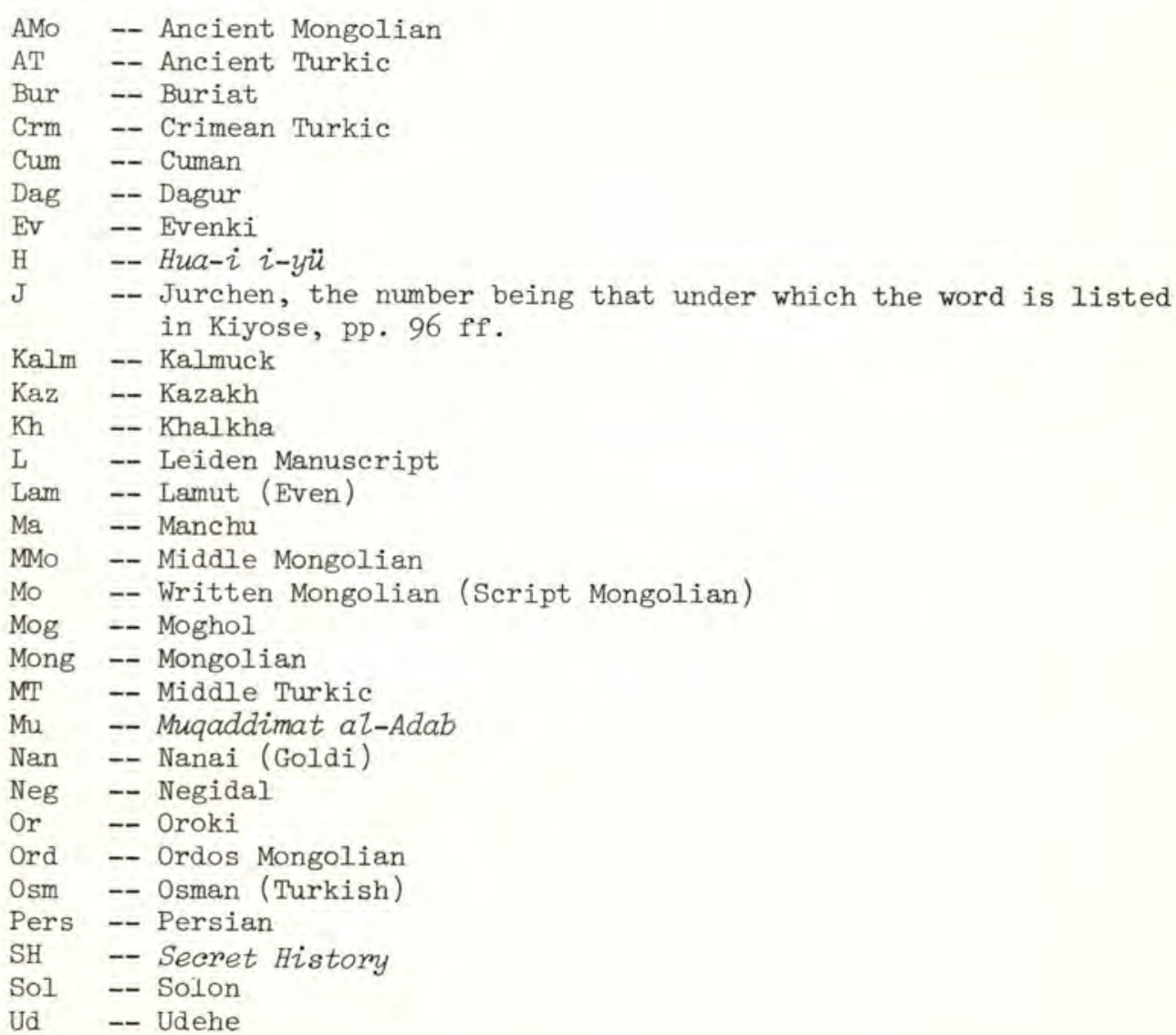


U1 -- Ulcha

$\mathrm{Uzb}$-- Uzbek

Yak -- Yakut

11. Menges, p. 249.

12. Menges, p. 250.

13. Ligeti, "Anciens éléments," p. 235.

14. N. N. Poppe, Mongol'skij slovar' Mukaddimat al-Adab, Čast' I - II (MoskvaLeningrad, 1938), p. 405.

15. Antoine Mostaert, Dictionnaire ordos, Seconde édition, (New York-London, 1968), p. 480.

16. Ligeti, "Anciens éléments," p. 234; Kiyose, p. 145.

17. Poppe, Mongol'skij, p. 202.

18. Mostaert, p. 188.

19. Ligeti, "Anciens éléments," p. 234-236.

20. Ligeti, "Anciens éléments," p. 235.

21. Poppe, Mongol'skij, p. 289.

22. Poppe, Mongol'skij, p. 97.

23. N. Poppe, "Ancient Mongolian," Tractata Altaica Denis Sinor Sexagenario Optime de Rebus Altaicis Merito Dedicata (Wiesbaden, 1976), p. 466.

24. Haenisch, p. 32.

25. Antoine Mostaert, Le matériez mongol du Houa $i$ i yu de Houng-ou (1389), édité par Igor de Rachewiltz avec l'assistance de Anthony Schönbaum (Bruxelles, 1977), p. 49.

26. N. Poppe, "Das mongolische Sprachmaterial einer Leidener Handschrift, Isvestiya Akademij Nauk SSR, 1928, p. 55.

27. In view of the ancient forms with $d$-, Mo taruli- and Kh tuuli- can be regarded as the results of incorrect pronunciation of this old word.

28. N. Poppe, "On some cases of assimilation of *i in Mongolian," CAJ 8 (1963), pp. $215-218$.

29. Cf. Sravnitel'nyj slovar' tunguso-man'čzurskix jazykov, Materialy $k$

ètimologičeskomu slovarju, Tom I: $a-n$ (Leningrad 1975), p. 167. Quoted below

as Sravnitel'nyj slovar.'

30. Ibid., p. 177 .

31. Ligeti, "Anciens éléments," p. 235.

32. Ligeti, Z.c., reconstructs this as xudira which is close enough to AMo ${ }^{*} k u d i r k a \overline{\text {. However, }}$ xudila is not impossible by analogy with ${ }^{*} x a d a l a, \mathrm{cf} . \mathrm{Ma}$ *xadaza 'bridle.'

33. Drevnetjurkskij slovar' (Leningrad, 1969), p. 464.

34. Poppe, "Ancient Mongolian," p. 466.

35. Sravnitel'nyj slovar', t.I, p. 259. The Yak form $\sin r \bar{a}-$ is not mentioned there. Instead, the word sargi ' fate' is given which does not belong here. Yak $s \ddot{r} r \gamma \bar{a}-$ is also missing in the index to Stanisław Kałużyóski's Mongolische Elemente in der jakutischen Sprache (Prace Orientalistycane, tom X) (Warszawa 1962).

36. Sravnitel'nyj slovar', t.I, p. 564.

37. For the last two examples see section 1 .

38. Cf. Sravnitel'nyj slovar', t.I, p. 423.

39. Poppe, "Ancient Mongolian," p. 464.

40. Poppe, Mongol'skij slovar' Mukaddimat al-Adab, pp. 44-46; N. Poppe, Introduction to Mongolian Comparative Studies (= MSFOu 110), Helsinki, 1955, pp. $96 \mathrm{ff}$.

41. Mostaert, Matériel mongol, p. 61. 
42. Sravnitel'nyj slovar', tom II: o - è (Leningrad, 1977), p. 249.

43. Martti Räsänen, Versuch eines etymologischen Wörterbuchs der Türksprachen (Helsinki, 1969), p. 386.

44. W. Bang, "Türkisches Lehngut im Mandschurischen," UJb. 4 (1924), pp. 15 ff.

45. Sravnitel'nyj slovar', tom I, p. 364.

46. Ibid., p. 448.

47. Ibid., pp. 387-88. On the developments of *k- see V. I. Cincius,

Sravnitel'naja fonetika tunguso-man'čzurskix jazykov (Leningrad, 1949), p. 215.

48. Sravnitel'nyj slovar', tom I, p. 358.

49. Poppe, Mongol'skij slovar' Mukaddimat al-Adab, p. 312.

50. Sravnitel'nyj slovar', tom I, pp. 409-410.

51. Ligeti, "Anciens éléments," p. 235.

52. Mostaert, Matériel mongol, p. 92.

53. Sravnitel'nyj slovar', tom II, p. 24.

54. V. I. Cincius, "0 sootvetstvii tunguso-man'čzurskogo anlautnogo $x-1 \mid 0$ tjurkskomu k-, q'-," Tjurkologičeskie issledovanija (Moskva, 1976), pp. 233.

55. Sravnitel'nyj slovar', tom I, pp. $42-43$.

56. Ibid., p. 522.

57. Nikolaus Poppe, Vergleichende Gramatik der altaischen Sprachen, Teil I: Vergleichende Lautlehre (Wiesbaden, 1960), pp. 41 and 57; N. Poppe, "The primary long vowels in Mongolian," JSFOu 63:2 (1962), pp. 1-2; N. Poppe, "On the long vowels in Common Mongolian," JSFOu 68:4 (1967), pp. 3-4.

58. Poppe, "Ancient Mongolian," p. 466.

59. Sravnitel'nyj slovar', tom II, p. 235.

60. Ibid., p. 282 .

61. Ibid., p. 102 .

62. Sravnitel'nyj stovar', tom I, p. 647.

63. B. Laufer, "Jurči and Mongol numerals," KCsA l:2 (1921), pp. 112-115.

64. Roy Andrew Miller, "Notes on the Jürcen numerals for the teens," UAJb 47 (1975), pp. 146-153.

65. N. Poppe, "The groups *ura and *üge in Mongol languages," Studia Orientalia $14: 8$ (1950), p. 11. See also Poppe, Introduction to Mongolian Comparative Studies, p. 246. J darhon, together with many other examples in Mongolian, proves that Mo $u$ ra $>\bar{o}$ assimilates the vowel of the preceding syllable: *dal-u-bān > Mo doluran. The J form also proves that Thomsen's objections are unfounded; see K. Thomsen, "Die Entwicklung der Gruppe *ura (*üge) im Mongolischen," Acta Orientatia 23 (1959), pp. 263-267. 


\section{ЭТНОГРАФИ VERSUS УТСААТНЫ ЗҮЙ}

Mary Frances Weidlich

Takoma Park, Maryland

Since 1921 many loan words have been introduced into the vocabulary of the Mongolian language in order to bridge the gap between the vocabulary of a nomadic society and that needed to express twentiety-century cultural, economic, political, sociological, scientific and technical concepts.

The following questions come to mind in conjunction with the introduction of foreign words: To what degree do loan words survive in Modern Mongolian? Are they always accepted? Or are they used synonymously with native counterparts which over a period of time have absorbed the essence of the meaning of the loan word? Or are they displaced by indigenous terms?

The purpose of this paper is to examine the current status of the loan word этнографи шith respect to its acceptance into Modern Mongolian, its alternation with native terms, and/or its displacement by indigenous terms.

The occurrences of этнографи and its native counterparts were observed for a consecutive seventeen-year period--that is, from 1961 through 1977--in articles focusing on social science topics or in sections of general articles dealing with social science subjects.

The data presented in this paper were taken from available issues of Ihнжээx ухаан (Science) published in Ulaanbatar from 1961 through 1964, its successor шинклэх ухаан амқдрал (Science and Life)l published in Ulaanbaatar from 1965 through 1977, and БНМАУ шинжтәх Ухааны Академийн Мэдээ (Transactions of the MPR Academy of Sciences) $)^{2}$ published in Ulaanbaatar from 1962 through 1977.

"Ethnography" is expressed in Modern Mongolian either by the loan word этнографи or by the following two native terms: угсаатны зүй, 3 literally translated "science of peoples," and үңдэстнүүдийн аж байдал, ёс заншил ба соёлпा судлах ухаан, 4 literally translated "studies of the way of life, customs, and cultures of nationalities."

During the seventeen-year period studied, этнографи was noted once in 1962 , three times in 1963, once in 1964, twice in 1966, once each in 1967 and 1970, four times in 1971, once in 1973, twice in 1975, and six times in 1976 for a total of twenty-two times.

Угсаатны зүй, the first indigenous term examined, was observed seven times in 1962, nine times in 1963, thirty-four times in 1965, eight times in 1966, nine times in 1967, seven times in 1968, eight times in 1969, six times in 1970, seven times in 1971, once each in 1972 and 1973, four times in 1974 and once each in 1975 and 1976. Thus, угсаатны зүй occurred for a total of 103 times.

Neither этнографи nor угсаатны зүй were observed in 1961 and 1966.

During the seventeen-year period investigated, the other indigenous rendition 38 
үндәстүүдийн аж байдал, ёс заншил ба соёлыг судлах ухаан was never noted. of its twenty-two occurrences, этнографи appeared in the genitive case fourteen times. The genitive form of этнографи modified both loan and native words. Examples of этнографи in the genitive case as a modifier of loan words include the following:

этнографийн материал "ethnographic material"

этнографийн музей "ethnographic museum"

этнографийн экспедиц "ethnographic expedition"

Examples of этнографи used in the genitive case as a modifier of native words include the following:

этнографийн судлагаа

этнографийн үзэ сгэлэн

этнографийн щинфилгээ

\author{
"ethnographic research" \\ "ethnographic exhibition" \\ "ethnographic investigation"
}

Furthermore, seventeen of the twenty-two occurrences of этнографи were in the immediate vicinity of another loan word, such as археодоги and палеонтопог.

of the 103 occurrences of the indigenous term, угсаатны з й occurred in the genitive case fifty-two times and modified both loan and native words. Examples of угсаатны зүй used in the genitive case as a modifier of loan words include the following:

угсаатны зүйн атлас "ethnographic atlas"

угсаатны зүйн материал "ethnographic material"

угсаатны зүйн отряд "ethnographic unit"

Examples of угсаатны зүй in the genitive case as a modifier of native terms include the following:

угсаатны зүйн зураг "ethnographic map"

угсаатны зүйн судлал "ethnographic study"

угсаатны зүйн холбогдол "ethnographic significance"

The ratio of use of этнографи to угсаатны зүй was $1: 7$ in 1962, 3:9 in 1963, $1: 0$ in $1964,2: 8$ in 1966, 1:9 in 1967, 1:6 in 1970, 4:7 in 1971, 1:1 in 1973, $2: 1$ in 1975 and $6: 1$ in 1976.

It is evident from these ratios that in 1963 and 1966 there was a slight tendency to use этнографи interchangeably with its native counterpart. However, this tendency became stronger in the seventies, especially in the years 1971, 1973, and 1975. In 1976, этнографи for the first time actually challenged the indigenous term.

It is clear from the above discussion that этнографи, both as an independent word and as a modifier, is gradually being accepted in Modern Mongolian and that its use seems to be somewhat dependent on whether another loan word is nearby. It is too early to predict whether этнографи will only be used synonymously with the indigenous term or whether it will ultimately advance to the role of the preferred term. 


\section{Notes}

1. This journal is sponsored by the Academy of Sciences of the Mongolian People's Republic and the Mongolian Society for the Dissemination of Knowledge and regularly contains articles focusing on a variety of subjects.

2. This periodical is a publication of the Academy of Sciences of the Mongolian People's Republic. It includes scholarly articles of various lengths dealing with a broad range of topics.

3. T. Damdinsüren, Opос монгол толь (Ulaanbaatar, 1969), p. 818; S. Natsagdorj, Орос-монгол товч тоाь (Ulaanbaatar, 1976), р. 403; and E. Vanduy, Орос-монгол нэр томьеоны толь (Ulaanbaatar, 1964), p. 556.

4. G. D. Sanzheyev, Opoc монгол толь (Moscow, 1960), p. 769. 


\title{
THE THREE SORROWING HILLS, MONGOLIA'S FIRST OPERA: AN EXAMINATION OF LITERARY AND MUSICAL GENRE*
}

\author{
Winston Wu \\ University of California, Berkeley
}

Although Mongols had loved song, music and dance as a form of domestic entertainment for centuries, 1 the appearance of more highly developed secular forms of synthetic art ${ }^{2}$ resembling theater as we know it came relatively late with the consolidation of Manchu power in Outer Mongolia. In the beginning of the eighteenth century local pang-tzu opera from the Chinese province of Shansi was imported by Chinese traders into several urban centers, and in all probability indigenous court theaters in several outlying districts 3 sprung up as a result of this. By the second half of the nineteenth century social ballads and dialogue operas, 4 built on a four-line folk song form often on the theme of social protest or longing for a lover known as hariltsaa duu, came increasingly into vogue, to the extent of becoming a type of nucleus for the creation of a national dramatic theater in the initial decades of the twentieth century.

Lubsan Huurchi, the famed epic singer and musician turned people's artist and composer of revolutionary songs, was the key person responsible for these social ballads and dialogue operas to become "urbanized" and "professionalized" in the capital and to be developed on stage right up to the opening of the State Music and Drama Theater in 1931. Stage plays fashioned on Chinese opera and employing Chinese dramaturgical effects en masse were performed side by side with classical repertoire of the regional variant of Chinese opera mentioned above. These plays often portrayed khans, princes and lamas as buffoons exploiting the arats. They generally circulated among "amateur circles" and, while successfully conveying political messages, were simplistic with regard to plot line and staging.

The Seventh Congress of the Mongolian People's Revolutionary Party in November 1929 and the Fifth Great Khural in January 1930 discussed the raising of cultural and educational levels in the country. It was pointed out that the "amateur circles" in question had indeed furthered the development of theatrical creativity, but were still unable to fashion a new theatrical art. ${ }^{\circ}$ As a result, new repertoire was not planned as such from then on, but rather intended as an experimental arena for new dramaturgists. With the closing of Chinese theaters 6 in 1929, a lacuna had somehow to be filled.

The Resolution of 1932, insuring Party control over new literary and artistic organizations in the Soviet Union, and Zhdanov's defining the aims of socialist realism at the First All-Union Congress of Soviet Writers in 1934 had inevitable repercussions on Mongolian literary and cultural life of that decade.

Following the successful performance of Not $I$ by the Mongolian State Music and Drama Theater at the International Olympiade of Revolutionary Theatrical Collectives in Moscow in 1933 and its participation that same year in the tenth anniversary of the Buryat Autonomous Soviet Socialist Republic in Ulan-Ude, the director of this work, D. Namdag, approached its author, today known as the 
founder of Mongolian national dramaturgy, ${ }^{7}$ D. Natsagdor $j$, once again with a request for more new repertoire.

Natsagdorj chose as the theme of this musical tragedy the leggend of Yunden Göögöö which is found in a book by B. Sodnom about Natsagdorj. ${ }^{8}$ It goes as follows:

In the middle of the nineteenth century lived the master craftsman Tsend. He had a tall, handsome son by the name of Yunden. Yunden was twenty-five years old when he set out on a caravan for China. He suddenly fell ill on the way and was forced to sojourn with the Khorchin tribe in Inner Mongolia. Having gotten well soon after, he could not depart from his host's house without a horse. But before long, when it was discovered that he was a literate person, he was assigned to the local clerk's office and made many acquaintances. Eventually he fell in love with Siriima who lived with her poor family in the neighborhood. The pampered Garva from a rich family, it turned out, was in love with Yunden. At that time the local Prince Bal was trying to marry off his son, but could not find a suitable bride. Garva heard about this and presented Siriima to him. Fearing Yunden, Prince Bal summoned him, bestowed on him an official title, made him a retainer and quickly sent him off to China on official matters. Thus ridding himself of Yunden, he married his son to Siriima. Yunden got the news of what transpired through his trusted comrades, returned and angrily attacked the prince. For this offense the youth was sentenced to death. Upon hearing of Yunden's death, Siriima took her life as well.

Natsagdorj carefully preserved the poetic origins of the legend in the course of writing the libretto for his new opera. He exalted above all the loftiness of true and undaunted love in the first version of the opera which appeared in 1934. The name of Yunden was retained from the legend; his beloved was called Nansalmaa. The rich feudalist Baldan resembled Prince Bal in the legend. However, this legend was reworked on a grand scale following its premiere in 1934 in order to present a clearly defined class viewpoint and to stress the psychological makeup of the characters. The perfidiousness of Garva was personified with greater detail in the character Khorolma, now a procuress. The relationships between Khorolma and both Yunden and Balgan were focused on in particular by the author with the intent of sharper delineation of the plot line.

In the period of autonomy in Mongolia (1911-21), a three-stanza social ballad of protest was composed about the fate of Yunden and is known to this day throughout Mongolia.9 Its lyrics are as follows:

With a braid down his back

Walking with a confident stride

The infinitely handsome

Yunden Göögöö Da-wang. 10

Walking with a sedate stride

With his braid plaited in three locks

Noble and light-hearted

Wonderful you are, Yunden Göögöö.

Da-wang of a Khorchin banner,

You sit at the place of honor in a yurt ${ }^{11}$ for naught

My beloved so far away

Why not return, Yunden Göögöö? 
It is evident from Namdag's memoir on The Three Sorrowing Hills that Natsagdorj was so inspired by this song that he was determined to create a brand new genre with his work. 12 It took him only two days to write the first act and to have it ready for rehearsal. Only a half month elapsed from the first rehearsal to the premiere performance of this unique musical drama. With personal concern for its success Natsagdorj often went to rehearsals to listen to advice from the artists.

Curiously enough, the original producer of The Three Sorrowing Hizls, E. Oyun, is also the author of Ardyn Hariltsaa Duu, Tü̈̈nii Ulamjlal (The Four-line Folk Song and its Traditions). In non-Mongolian sources hariltsaa duu is called "Wechsellied" or "Dialoglied" by Heissig,13 "conversation song" by Bawden, 14 and "four-line song" by Salga. 15 Oyun basically agrees with Heissig that the foundations of indigenous Mongolian literary theater lie in this highly versatile song form. She divides the genre into six categories: robber's songs, satirical and jesting songs, laments, lyrical songs, epic songs and odes. She is of the belief that repertoire in all six embodies national, class and ideological content to varying degrees and that its heroic-dramatical forms ${ }^{16}$ reflect the struggle against the oppressor class. Mention is made of lyrical-humanistic songs and those instructive in love which reflect the social problems of the day.

The theme of humanism is touched on briefly in the second version of our opera where mothers rock their children to sleep with cradle songs and gather young lads for a hunt at sunrise the following morning. The young maidens now enter and join them together in a chorus about the sun overcoming darkness and emitting golden rays of happiness to people. On the other hand, in the Buryat ballet Blossoms of Life the central theme is this very dualism of light and darkness where the noble and valiant folk hero Bator overcomes great odds to lead Mother, her three daughters, and the people to light and happiness.

In resolving the problem of thematic content in both versions of The Three Sorrowing Hills, another Buryat ballet In the Name of Love, composed by $\mathrm{Zh}$. Batuyev and others in 1956-7, provides parallels more focal to the main themes in both. In very broad terms, this ballet, known as lyrical-heroic drama, 17 in effect combines the lyrical-melodramatic of the first version of our opera with the heroic-epic of the second version staged in 1942, for it unites the fate of the protagonist Zorigto with that of the people amidst tragedy, the death of their beloved seseg. It stands in contrast to the first version of The Three Sorrowing $\mathrm{Hi}_{\mathrm{Z}} \mathrm{s}$ which concludes in semi-tragedy with Nansalmaa killing the wicked feudalist Baldan and the wounding of the hero Yunden, but with the common people playing no role in it. The second version does unite the fate of the protagonists with that of the people throughout the entire opera, but amidst comic relief provided by the joyous wedding of Yunden and Nansalmaa.

The theme of eternal love and the presence of the so-called masses on stage are not unfamiliar phenomena in theater elsewhere in the world. The 1934 version of The Three Sorrowing Hills is quite appropriately termed romantic-pathetic melodramal8 with a theme of eternal love on the order of the very popular Chinese legend and opera Liang Shan-po and Chu Ying-t'ai 粱山伯與祝英台 and, to a lesser extent, of the Uzbek poetic legend Farkhad and Shimin. ${ }^{9}$ Strangely enough, when we revert back to the original legend of Yunden Göögöö, Siriima takes her own life upon hearing of the death of Yunden - the same fate befalls Juliet upon the death of Romeo. 
When examining such heroic-epic classics of Russian opera as Borodin's Prince Igor and Glinka's Ivan Susanin, we note that the traditional amorous-intimate plot line is seldom an essential part of these operas. Yet once it becomes an integral, subordinate component of them, it is transformed into a domesticverismo plot line. These two operas, and ours as well, do not fit well into the standard mold of amorous love, seen by Stalinist opera critics as a Western petty bourgeois aesthetic tendency. 20 Thus the Mongolian hariltsaa duu form, instructive in love, somehow found itsidentity with such classical tragedies as Romeo and Juliet, Othello, Hamlet, and Boris Godunov which in the eyes of these critics all focus on inevitable or probable consequences of various social problems.

As Mussorgsky puts it, the developmental aim of tragedy is the common fate of the individual and the people. 21 Seen in a broader Soviet context with regard to both classical Russian and the best of Soviet opera, the experiences of the individual become an organic part of the depicted social events, with the inner conflicts of the protagonist transformed into conflicts of his society. As applied to our opera, it was death as a natural consequence of a sequence of causes rather than a portrayal of eternal love which made Ivan Susanin acceptable in Stalinist eyes but not the first version of our opera staged in 1934 .

The appearance of mass scenes in Mongolian and Buryat opera is particularly vivid in the 1942 version of our opera, in which we find amazing similarities with Glinka's legendary opera Ruslan and Ludmilza. In place of Chernomor's slaves and servants are the khan's servants and Yunden's warriors. At the end, instead of the people of Kiev rejoicing and glorifying Prince Ruslan's awakening Ludmilla, it is the arats who joyously celebrate the marriage of Yunden and Nansalmaa. In both operas a fairytale atmosphere is evoked with magnificent stage sets depicting magical castles and palaces.

Right up to the beginning of the 1930s the highly skilled art of improvising on musical core units known as hariltsaa duu by huurchis with Lubsan Huurchi at the fore continued hand in hand with the spontaneous composing of lyrics, now increasingly in step with the times. The accompaniment to new so-called revolutionary songs still remained heterophonic, characteristic of a number of traditional musics of East Asia and medieval European music. The traditional pentatonic scales, ${ }^{22}$ more or less intervallically equivalent to the Dorian and Mixolydian modes, remained intact up to this time.

After the State Music and Drama Theater was founded in 1931, such traditional plays as Prince Sum'ya, known as one-actor dramas 23 because all the performers' parts were sung in one and the same motif, began being actively reworked. Satirical dramas in a semi-improvised style such as Deceptive Trust, The Avaricious Lama, and Conversation of the old Man and Woman were simultaneously staged. Perhaps the first time anything resembling operatic art song was used was in the play Dark Force by Buyannemekh in what B. Smirnov, a co-composer of The Three Sorrowing Hills, terms pesennoye nachalo spektaklya, the vocal beginnings of drama. 24

1934 and 1935 were a turning point in Mongolian theatrical history for they marked the beginnings of a new art form with a new aesthetic basis. 25 The Three Sorrowing Hills was already a considerable step forward from Prince Sw'ya in 
that it contained four, instead of merely one, distinct motifs based on folk songs. This increase, however, was not matched by a corresponding increase in the number of individual character traits. Moreover, it was premature to introduce feelings of the characters in terms of psychologism into such a work. 26

In the second version of The Three Sorrowing Hills B. Damdinsüren and cocomposers added leitmotifs to the original motifs, yet the same monotony of musical expression prevailed throughout the work. What the composers did accomplish, musically speaking, was to introduce Western-style duo singing, for example, in the dialogue of love between Yunden and Nansalmaa which was wholly constructed in parallelism, the most widespread manner of folk poetry discourse. It was actually a musical realization of the call-and-response character of the hariltsaa duu which was traditionally always soloistically sung. 27

Poetic lyricism and imagery are well known in the works of D. Natsagdorj who employed them generously in the libretto of his first opera. Natsagdorj drew from the rich treasure of epithets, similes and metaphors in folklore, especially from $\ddot{u l i g e r s, ~ a n d ~ u t i l i z e d ~ h i s ~ o w n ~ t e c h n i q u e s ~ o f ~ p a s t o r a l ~ l y r i c i s m . ~ H e ~ e x p a n d e d ~}$ as well on themes from folk songs of different genres. In the newly conceived second version he attempted to show as vividly and graphically as possible the basic principles which distinguished the main characters of the drama. Nansalmaa's poetic image was now to become the embodiment of the finest traits of Mongolian women and could perhaps be likened to the psychological depth and fidelity to life of Natasha in Dargomyzhskii's Rusalka. All we are able to say about musical imagery in the opera is that it is watered down and lacks the maturity of form the libretto had attained.

In spite of the Buryat opera In the Name of Love being composed in a much later era and thus being more musically sophisticated than our opera, we see a potential for musical maturity in an opera such as The Three Sorrowing Hills, as was the case in subsequent Mongolian operas. The Buryat ballet makes extensive use of polyphony, in particular a device known as contrastive polyphony (polymelody ?) or modulatory imitation of key pitches. The theme of love in the solo arias of Zorigto and Seseg is conveyed in a light type of major tonality against a bustling backdrop, whereas the opening measures of Dalyu's theme employ the salient tritone of $\mathrm{B}$ minor in sharp contrast. In general, dissonant harmonies in the form of unstable, clashing tonalities bordering on the grotesque depict the coldhearted and implacable Dalyu.

In 1934 and 1935 two new theatrical works, The Three Sorrowing Hills and Princess Dolgor and Arat Damdin, appeared under the appelation högjimt jüjig "musicdrama play." However, it was not by coincidence that these operas, also called ayalguut jüjig, were quite similar in the style to the so-called song-operas prevailing in the thirties in the Soviet Union. The Three Sorrowing Hills, very broadly speaking, shares with song operas like Khrennikov's Inta the Storm such basic principles as simplicity, directness and folkishness, and with Asafiev's ballet music a concreteness in musical language with regard to national color and popular customs. Nonetheless, our opera was set in pre-revolutionary Mongolia and thus could not identify with very concrete aspects of thematics in Soviet operas and the developing of appropriate artistic devices for them. The shortcomings of The Three Sorrowing Hills were consequently of a very different nature from those of many short-lived Soviet song operas of the thirties. We may draw a few analogies from the Ukrainian historical opera Bogdan Khmel'nitskii by $\mathrm{K}$. Dankevich, presented at a dekada of Ukrainian art and literature in Moscow. 
Although its libretto and historical genre were quite different from our opera, it was likewise an underdeveloped music-drama play or musical folk drama.28 As in our opera, its operatic episodes were based on authentic national melodies (dumas), and it had little variation with respect to musical characterization of the main characters. As opera critics saw it, downplaying the role of the people in Bogdan Khmel'nitskii and omitting it altogether in the first version of our opera surely fell short of the great historical-folk drama traditions of Glinka, Mussorgsky and Tehaikovsky. 29

Similar tasks of overall revision, enriching the thematic content and raising the ideological and aesthetic levels, lay ahead of these two operas. As Stalin formulated the task of creating a classical Soviet opera, so Mongolia was obliged to create a classical Mongolian opera.

To achieve this meant reverting to or repeating the prior classical cycle of development of Russian music culture 30 or, more specifically, using folk melodies in art music, a trend having its origins in nineteenth-century European nationalism. We should recall a review of Glinka's first opera in the Moscow Observer in 1836 where a talented composer of the time, G. Verstovskii, postulated that to create an opera meant employing unadulterated folk motifs and sometimes imitating them, whereas Glinka would study the character of the folk music and subsequently employ full freedom to musical creativity. This level of creativity was impossible to attain in the initial versions of The Three Sorrowing Hills, not to mention those first operas of several of the Soviet Central Asian republics where so-called professionalism in music was non-existent prior to 1917. What these initial attempts at opera amounted to were loosely strung sequences of medleys, often sharing with Soviet operatic fiascos such general musical traits as insufficient expressivity in arias.

Natsagdorj did not change the first version of the libretto of The Three Sorrowing Hills enough to conform to the positive hero type in modern Soviet operas and thus to insure its subsequent success although, as we have seen, positive heroes had already existed in classical Russian opera. We might add here that Prokofiev was looking for less schematic librettos about positive and heroic types and suitable to be set to music to avoid creating mere "dramas set to music," whereas in our opera it was the musical motifs rather than those in the libretto which fell short of the norm in terms of schematism.

By way of concluding, let me say that The Three Sorrowing Hills became foremost among several stage plays covering a wide range of love themes, from the traditional dialogue opera Prince Sum'ya to several others featuring arats, often female, as central characters. Unlike the Soviet song-operas of the thirties mentioned earlier, our opera served as a model for subsequent Mongolian operas and has survived to this day as a major work of national operatic repertoire. Because it contains a good deal of folkloric idiom and imagery not unfamiliar to the common people, our opera has been widely performed by amateur circles on club stages outside the capital.

The new budding Mongolian opera at the same time was very far removed from such schools as expressionism, formalism, primitivism and exoticism contending in the Soviet Union at the time. They were avoided in Mongolia in order to nationalize various musical forms within the country and to train theatrical cadre in conformance with Soviet norms. 31 
A gap in Mongolian performing arts had now been essentially filled, something so vitally needed upon the conclusion of the International 0lympiade of Revolutionary Theatrical Collectives in 1932. Suddenly such new paraphenalia as stage sets, stage presence, lighting and applause made their first appearance on the Mongolian theatrical stage, yet the aura of the Chinese "costumed drama" (ku-chuang hsi-chü 古裝戯劇) ) still lingered on. 32

\section{Analysis of the Music Transcription}

Our opera consists of a prelude, an interlude, a battle scene and several songs, including arias and duets. 33 The two solo arias we are examining are basically constructed in two pentatonic (five-tone) scales, Baldan's song being in the so-called Dorian mode (E G A B D) and Nansalmaa's song in the so-called Mixolydian ( $B b C E b F$ G). In the former, brass and percussion predominate to depict evil, whereas in the latter the warm timbres of strings (pizzicato is utilized to accentuate beats) and woodwinds in occasional imitation of the vocal line convey a lyrical-amorous quality. 34 Both are constructed in strophic form, disregarding the orchestral tutti at the beginning of Baldan's song. The Russian terms kuplet and pripev are used to denote this particular form.

The use of motif's in both songs are of particular interest. Baldan's song is totally in the style of the Soviet mass song employing a dotted rhythm in the first four measures and a syncopated rhythm thereafter as recurring rhythmic patterns or rhythmic motif's to evoke a march rhythm feeling. In Nansalmaa's song we find a melodic or folk song motif beginning with B C E, which G. Uvarova erroneously calls maimachenskiye motivy. 35 This recurring pattern is then transposed a fifth higher, becomes a reverse motif in measure 3 , is inverted in measure 4, then is finally resolved in measure 5. Nansalmaa's song generally takes on the character of a lyrical-romantic song with measure 9 briefly making an incursion into the relative minor of $\mathrm{Eb}$ major, then reiterating the notes of the scale one last time in the style of the long song with the last two sixteenths reminiscent of a laryngeal trill. The usual dominant-tonic resolution then follows. 
The Three Sorrowing Hills

Libretto by D. Natsagdory and Ts. Damdinsüren

Music by B. Damdinsüren and others

Accompanied by the Mongolian State Theater Orchestra,

Chuluun, conducting

SALDAN'S SONG SOTO mate arta sung by Noroonjar
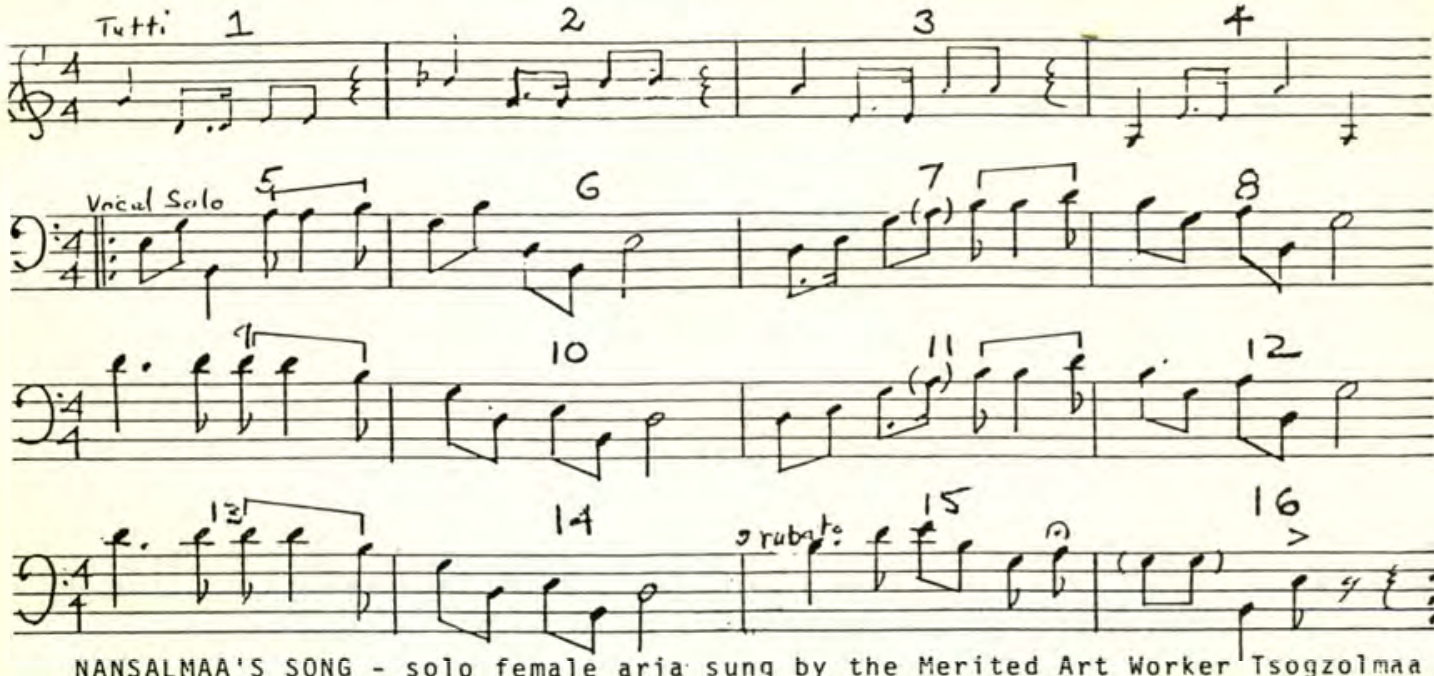

NANSALMAA'S SONG - solo female aria sung by the Merited Art Worker Tsogzolma $\sum_{1}^{5} 5$

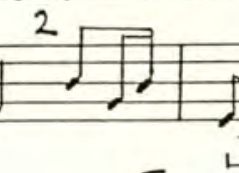

3
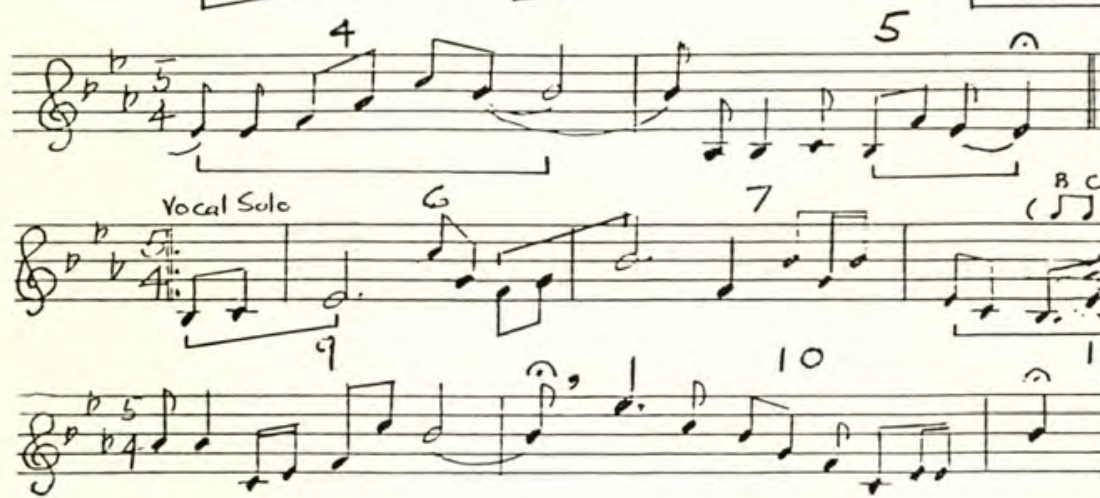

$\left(\int^{B}\right)^{C} \hat{O}$

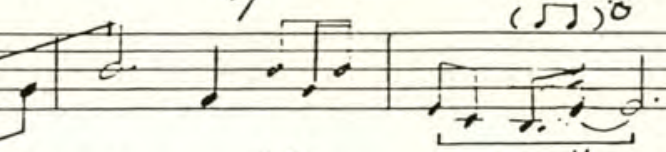

$\therefore, 1,10$

11 
Text of the ballad Yunden Göogoro

(B. Smirnov, Mongol'skaya Narodnaya Muzyka)

\section{3. Юндэн гөөгөө юндэн гого}

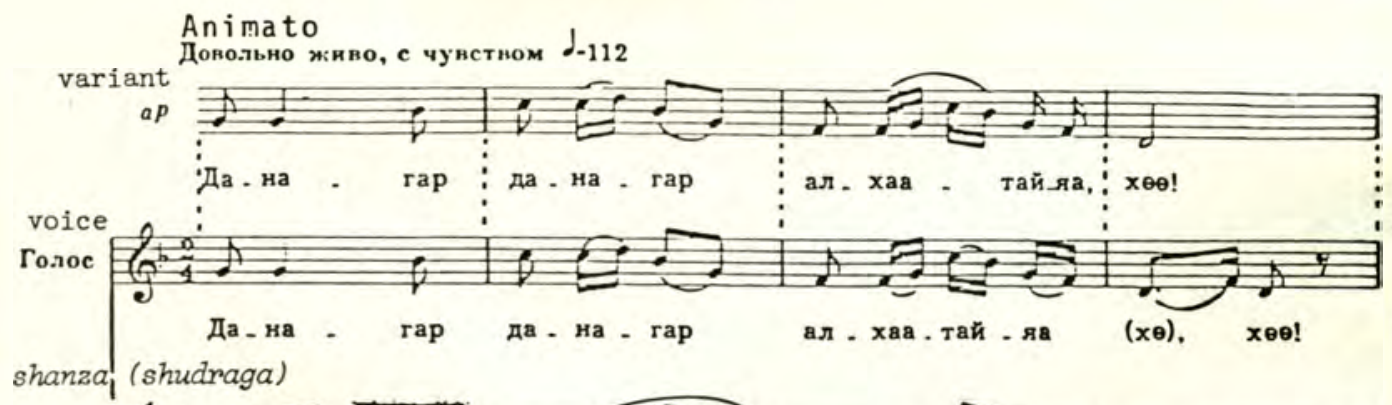

ІІІаная
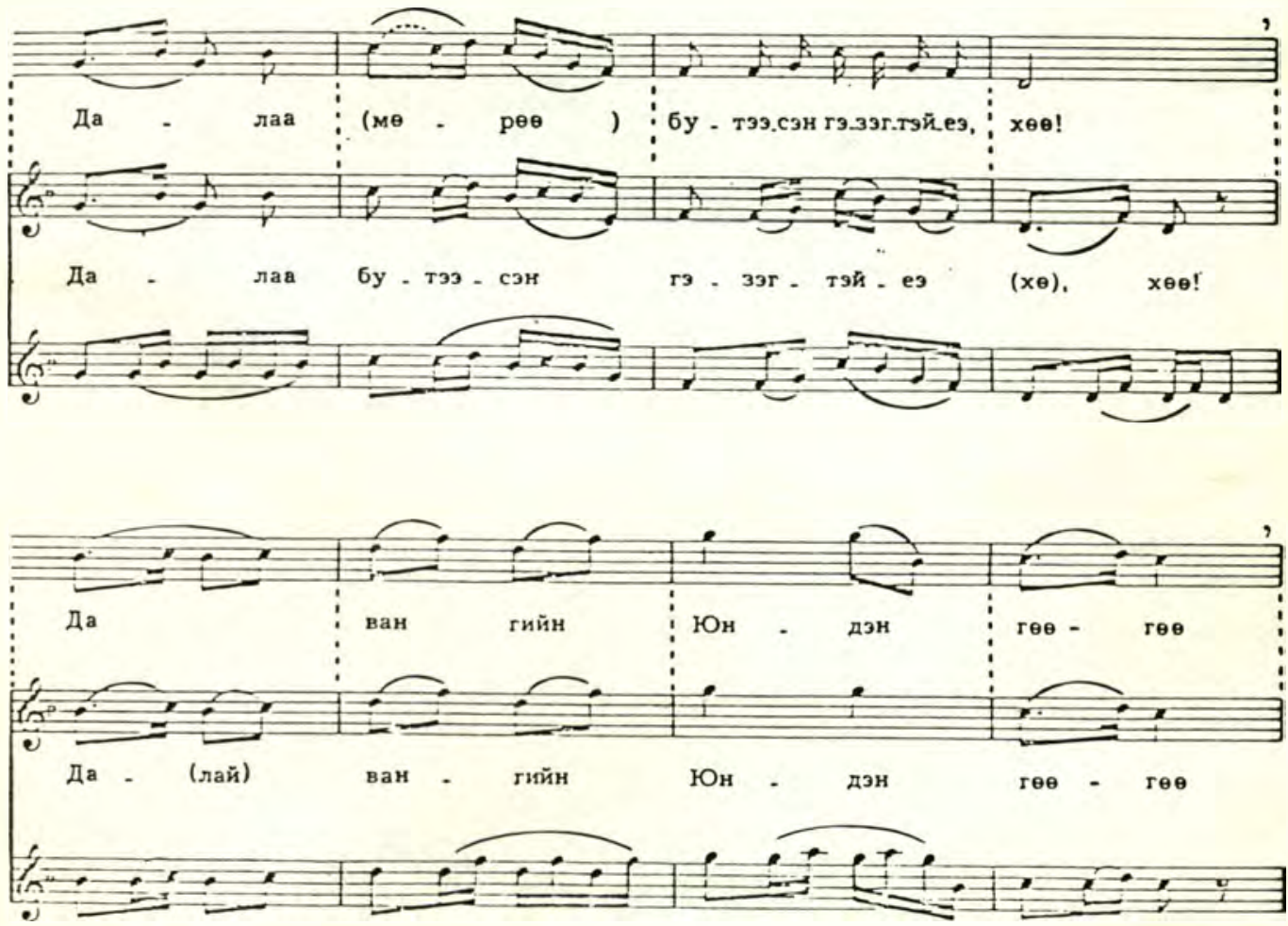

1) : Syxckon mun. 


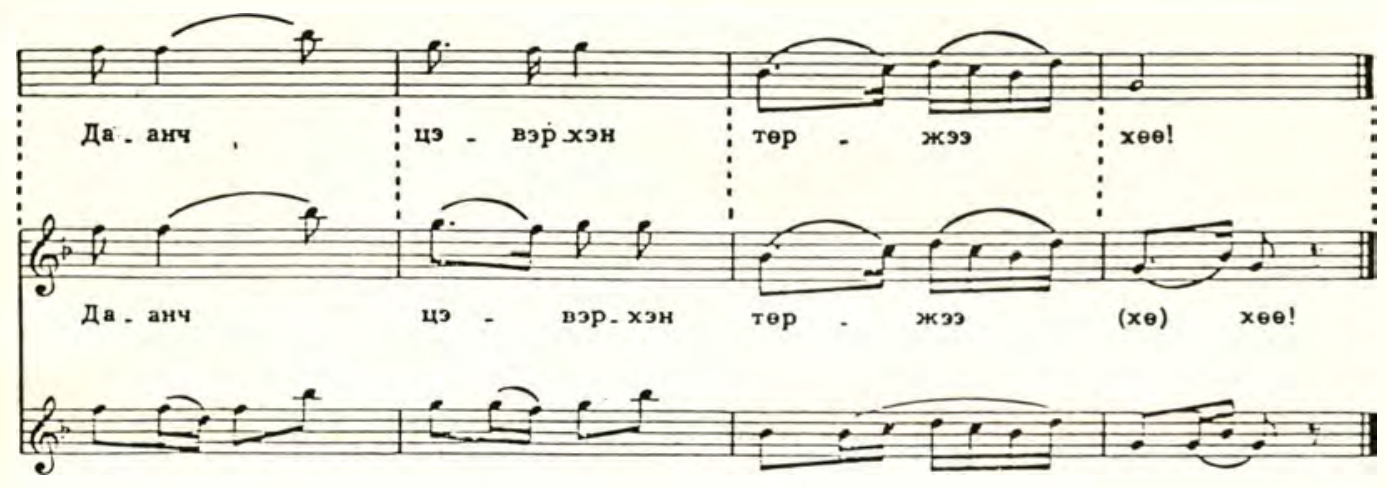

Данагар данагар алхаатайяв, хөө!

Далаш 6утээсэн гэзэгтйез, хөө!

Да вангийн Юндэн гөєгөө

Даанч цзвэрхэн төржзз, хөө!

Гунагар гунатар алхаатайяа, хөө!

Гурваар дарсан гэзэгтэйеэ, хөө!

Гунхсан сайхан Юндэн гөөгөө

Гуниггүй цэвэрхэн төржэз, хөө!

Хорчин хушууны Да-ван чинь, хөө!

Хоймроор морилох нь юуных вэ, хөө!

Холд явсан Юндэн гөөгөө минь, хөө!

Хонгортоо ирэх нь яагаа вз, хөө!

С косою, падающей на спину,

Шагающий уверенной походкой,

Безмерно прекрасньй,

Юндэн Гого Да-шана1).

Стеленной походкой шагая,

С косой, заплетенной из трех прядей,

Чистый и беззаботный,

Прекрасен ты, Юндэн Гото

Да-ван хорчинского уезда,

Чего ради располагаешься на хойморе ${ }^{2)}$,

Далеко уехавший мой нозлюбленмый,

Почему не возвращаешься, Юндэн Гого?

1) Администратинный чия в стирой Монголик.

2) Почетное место в юрте. 


\section{Notes}

*The name of our opera as it exists today is O Tryokh Sud'bakh (The Destinies of Three) with no allusion to sorrow. ("Tvorcheskoye sotruzhestvo masterov kul'tury" [Joint artistic creativity of the masters], Mongoliya, no. 10 (238), October 1978, p. 10.

1. G. A. Uvarova, Sovremmennyi Mongol'skii Teatr [Contemporary Mongolian Theater] (Moscow-Leningrad: "Art" State'Publishers, 1947), pp. 15-16.

2. The religious counterpart of synthesized art was to be found in tsam, so-called mystery plays featuring masked pantomime and ritual dances which were imported from Tibet into Mongolia in the 1870s. According to Uvarova, pp. 21-22, religious and secular drama developed completely independently of each other due to their different functions in society.

3. Chinese theatrical troupes became established in such towns as Kobdo, Uliastai and Kiakhta where Chinese trading communities known as maimaichen had sprung up. In Urga Chinese theaters were set up rather late with the increased influx of Chinese settlers and consequent staging of Chinese theatrical performances in more sedentary Mongol areas. Yet at the palaces of the spiritual rulers of Mongolia, the gegens, epic-singers and musicians were always present to offer entertainment for their families and guests.

4. These forms are dealt with in a number of works primarily as literary or folkloric genre. K. H. Yatskovskaya in her article "K voprosu o zhanre pesni $v$ sovremennoi mongol'skoi literature" [On the problem of song genre in modern Mongolian literature] in the Proceedings of the Third Intermational Congress of Mongolists (Ulaanbaatar: Permanent Committee on the International Congress of Mongolists, 1972), pp. 262-265, uses the word pesnya (song) to mean a literary form in vocal style, citing the play Ih Avgai [The Old Woman] with the role of the khuurchi being absent. We are, on the other hand, only interested in those forms where his active musical role is present.

5. Uvarova, p. 60.

6. They performed both authentic Chinese and Mongolian dramas in Chinese style such as Ushandar Khan.

7. Ludmilla Gerasimovich, History of Moderm Mongolian Literature (1921-1964) (Bloomington: Mongolia Society, 1970), p. 90.

8. B. Sodnom, D. Natsagdorjiin Uran Zohiolyn Tuhai [On the Works of D. Natsagdorj], Ulaanbaatar, 1959.

9. Boris Smirnov, Mongol'skaya Narodnaya Muzyka [Mongolian Folk Music] (Moscow: Soviet Composer, 1971), pp. 149-150. See facsimile of original work on $\mathrm{pp}$. 49-50.

10. An administrative rank in old Mongolia (< Chin. 大王).

11. Hoimor.

12. Klara N. Yatskovskaya, Dashdorzhiin Natsagdorzh: Zhizn' i Tvorchestvo [D. Natsagdorj: His Life and His Works] (Moscow: "Science" Publishers, 1974), p. 117 .

13. Walther Heissig, Geschichte der mongolischen Literatur [History of Mongolian Literature] (Wiesbaden: Otto Harrassowitz, 1972), p. 641.

14. Charles Bawden, "The Mongol 'conversation song,'" in Aspects of Altaic Civilization (Bloomington, 1963), pp. 75-83. On p. 80 he uses an alternate term "ballad-opera" and speaks of "not a very wide variety of theme, as far as can be judged" dealing with bold warriors, dissolute girls and lamas, the parting of lovers through death, marriage to another, and the returning of a 
traveler whose beloved has married another. Compare with E. Oyun's classification of hariltsaa duu genre in the main body of the text.

15. Mária Salga, "On Mongolian four-line songs in general," Canada-Mongolia Review 2:2 (1976), pp. 120-126.

16. D. Batsüren and J. Enebish, Duunaas Duur' Hürsen Zam: Mongolyn Orchin Üyeiin Högjmiin Uran Büteeliin Tü̈̈hen Toim [From Song to Opera: A Historical Sketch of Contemporary Mongolian Musical Works] (Ulaanbaatar: Mongolian Composers' Union, 1971), p. 139. Compound adjectives in Russian and Mongolian are frequently used to specify song and opera, as well as mention literary genre of one kind or another.

17. Muzykal'naya Kul'tura Buryatii [Music Culture of Buryatia], the fourth in a series on the history of fine arts issued by the Buryat Academy of Social Sciences of the Academy of Sciences of the USSR, Ulan Ude: Buryat Book Publishers, 1967, p. 66.

18. Uvarova, p. 114.

19. G. Mikhailov and Klara N. Yatskovskaya, Literatura Vostoka: Mongol'skaya Literatura - Kratkii Ocherk [Oriental Literature: A Brief Sketch of Mongolian

Literature] (Moscow: "Science" Publishers, 1969), p. 168.

20. It is perhaps appropriate to mention here a controversy over the kiss in Ulaanbaatar several decades ago.

21. Ye. Grosheva, "Obraz naroda v sovetskoi opere" [The image of the people in Soviet opera), in Sovetskaya Opera: Sbornik Kriticheskikh Statei [Soviet Opera: A Collection of Critical Essays] (Moscow: State Music Publishers, 1953), p. 235.

22. Their relationship to the complexities of the Chinese adjustable pentatonic systems which in actuality consist of seven tones will not be dealt with here.

23. One-actor dramas or one-actor theater (Bawden, p. 78) shares similarities with various northern Chinese ballad-operas as single-instrument accompaniment with Pei-ching ch'in-shu 北京琴書 or tan-ch'in ta-ku 毣琴大鼓 (Peking ballad-opera) and singing from a sitting position with tsuo-ch'iang mei-hua 坐腔郡雱点 (Mei-hua "sitting vocal style" ballad-opera) See Shan-tung taku: Li-hua ta-ku, Chiao-tung ta-ku 山束大鼓: 犂銓大鼓, 膀束大鼓 [The BalladOperas of Shantung Province], ed. by Yü Hui-yung 余會泳 (Peking, "Music" Publishers, 1956), p. 22. Singing all performers' parts in one and the same motif is uncharacteristic of Northern Chinese ballad-opera vocalization in general.

24. Smirnov, p. 62.

25. Ibid., p. 61 .

26. Salga, p. 122, speaks of the manifestation of feelings in the four-line song as follows: "The folk singer chooses the aptest of expression from the inventory freely used by the community." This traditional sense of social identity could be construed as the element of folkishness in later versions of our opera.

27. In this connection we should take note of the appearance of duo singing as a distinct musico-literary genre in Inner Mongolia in the second half of the eighteenth century. This "two-actor theater" both with singers and dancers became particularly known with the works of Erzen'tei (Smirnov, p. 65). I believe it is now called holboo shüleg (couplet poetry). See G. Kara, Chant d'un barde mongol (Budapest: Akadémiai Kiadó, 1970).

28. "On the opera 'Bogdan Khmel'nitskii,'" in Sovetskaya Opera, p. 29.

29. A. Shaverdyan, "Pisatel' i sovetskaya opera" [Writers and Soviet opera], in ibid., p. 150. 
30. P. Apostolov, "Nasuschchye problemy Kazakhskoi muzyki" [Urgent problems in Kazakh music], in ibid., p. 197.

31. Uvarova, p. 76.

32. In the premier performance of The Three Sorrowing Hills the actual wardrobes of the former nobility apparently provided some costumes for the performers. See D. Namdag, "Uchirtai Gurvan Tolgoi" [The Three Sorrowing Hills] in D. Natsagdorjiin Thhai Durtgal, Temdeglel [Accounts and Memoirs Relating to D. Natsagdorj] (Ulaanbaatar: Committee on National Publications, 1966), p. 21. 33. Batsüren and Enebish, p. 77.

34. A similar use of these orchestral timbres is found in the ballets of Zh. Batuyev (Muzykal'naya Kul'tura Buryatii, p. 65). 
HISTORY 


\title{
IMPRESSIONS OF INNER MONGOLIA, 1945-1950
}

\author{
Frank B. Bessac \\ University of Montana
}

The following essay briefly chronicles three trips I took to Inner Mongolia, some events, serious and humerous, which took place on these trips, and some of my impressions cast in terms of Chinese-Mongolian relations.

The trips to and within Inner Mongolia were made for various reasons, to different areas, and by diverse means of transportation--by plane, jeep, horse, truck, and camel. My first trip was by jeep and plane from Peiping to Kalgan, Dolon Nor, and Peitzemiao and back in the late winter and early spring of 1946. The second trip was from Peiping to and throughout the Ordos (Ikechou) and Ulanchap areas and return from May to October of 1948. The third trip I took as a Fulbright scholar from Lanchow to Ninghsia and Ting-yüan-ying, the administrative center of the Special Alashan Banner, and from there by camel across the Gobi to Shan-tan in the Kansu Corridor in the summer of 1949.

Each trip was made under different auspices and for different purposes. At the time of the first trip I was a member of the organization which was a continuation of the wartime Office of Strategic Services. There were a series of administrative changes which those of us in the field paid little attention to as we still thought of ourselves as members of the O.S.S. I recall that at the time we were as yet not called the Central Intelligence Group and that the reorganization into the Central Intelligence Agency was to occur months later. I had just returned from a mission to the Chi-Chung Liberated Area south and southeast of Peiping, where we studied the type and causes of truce violations taking place.

At this time the peace talks between the Communists and Nationalists, under the auspices of the United States and the personal guidance of General George Marshall, were still taking place but were steadily losing impetus for a number of reasons. One of these was the continual skirmishing between small units of Communist and Nationalist forces. From what I could observe, the skirmishing in the Chi-Chung was set off by groups of foragers on the Nationalist side. These troops were not well provided for, seemed to resent the villagers for harboring the Communists, and apparently felt little compunction about taking a moderate amount of hay for their animals and grain for their own consumption from the countryside. The Communists, on the other hand, could hardly allow foraging of this type to take place as it would show a lack of Communist ability to protect areas under their control and because it could be interpreted as a form of taxation. The Chi-Chung at this time was a well-establsihed Communist area even though it had been surrounded by the Japanese for years. As such it had developed a history as a guerrilla base. Both the intricate system of tunneling and the sense of unity testified to this history. With the completion of this mission we learned that the Chin-Ch'a-Chi base area wished some sort of liaison with our unit, perhaps because of the flexibility with which we could 
operate and, at that time at least, impartiality in the civil war. Thus the stage was set for additional trips into the Chin-Ch'a-Chi area.

My first trip was precipitated, from the American point of view, by events taking place in Inner Mongolia. Mongols living in the area, to a large extent former members of the Japanese-sponsored semi-autonomous political organization in Manchuria, held a meeting in a village near Wang-yeh-miao in the west-central Hsinggan Mountains and authored the rationale for an Eastern Mongolian Autonomous Government. This was hardly a revolutionary act as the area, as I came to understand it, was largely self-governing although more by default than by the assertion of independence or autonomy. Representatives of this government were sent to various powers in the region in order to secure sponsorships. The Soviets replied that the time was inappropriate but that at a later date the Mongols might indeed benefit from Soviet influence. Authorities within the Mongolian People's Republic (M.P.R.) replied in very similar terms. At that time the M.P.R. was very concerned for its own standing as an independent government and wished to secure recognition from the United Nations. The representatives who traveled to Peiping to discuss the issue of sponsorship with the Chinese Nationalists had hoped to travel on to confer directly with Chiang Kai-shek, but were not allowed to do so. They were mostly met with indifference. In part as a consequence of these failures, a meeting was scheduled for March 1946 in Ch'eng-te with the permission and probably with the encouragement of local authorities within the Chinese Communist political organization which controlled this part of southern Manchuria.

It was agreed upon that I leave for Kalgan, the administrative center of the Chin-Ch'a-Chi base area, to learn more about this Mongolian movement and the Chinese Communist responses to it.

Upon my arrival in Kalgan I asked Ulanfu about the meeting at Ch'eng-te and was astonished to learn that he had not heard of the eastern Inner Mongolian movement. The next morning Ulanfu departed for Ch'eng-te. Ulanfu gave me the impression of a Chinese Communist official although he wore a Mongolian gown during our second meeting. It was said that he did not speak Mongolian which was not surprising for a Tümet of his generation. The Independent Provisional Mongolian Republic which had come into existence in the fall of 1945, upon the arrival of troops from the M.P.R. and the Soviet Union, had been terminated when the Chinese dominated the area. Leaders of the Independent Provisional Mongolian Republic allegedly were executed by the Chinese after they had been invited by Ulanfu to leave Shangtu and come to Kalgan.

Not only Ulanfu but no one else seemed to be knowledgeable about the situation in those areas of Inner Mongolia inhabited chiefly by Mongols when I visited Kalgan. Therefore I decided to travel to Dolon Nor by jeep, accompanied by representatives of the Chin-Ch'a-Chi Liberated Area to discover for myself who was in control.

Dolon Nor turned out to be a Chinese town on the margin of the area inhabited by Mongols. We visited the temple just outside of town which the Chinese Communists said had been saved from total destruction by troops from the M.P.R. Soviet troops had apparently begun to burn down this temple when M.P.R. troops surrounded the temple and thus saved it from further destruction.

There were no representatives of any Mongolian government at Dolon Nor and 
no one who seemed to have any information about the situation in the Mongol regions. Amazingly I was able to persuade a U.S. Army plane to fly to Dolon Nor, pick us up and take us to Peitzemiao to the northwest of Dolon Nor in Shilingol League and then to return in a few days to pick us up again at Peitzemiao and bring us back to Dolor Nor. We would have used the jeep instead if we had carried with us or been able to obtain sufficient gasoline, but this rather bizarre means of transportation turned out to be the only way. The airfields at both Dolon Nor and Peitzemiao were emergency landing fields, built by various military forces, Japanese or Soviet, that had passed this way. The one at Dolon Nor had more of the outline and structure of an airfield than that at Peitzemiao. As there were no communications between Kalgan and Peitzemiao, let alone between Peitzemiao and Dolon Nor, we could only hope that the field at Peitzemiao was operational and that we would be welcomed when we arrived.

All came off splendidly with the Chinese in our party excitedly pointing out yurts below us on the steppe as we skimmed over them, slowly circled the temple complex, and landed on a field outlined by the red gowned lamas from the temple. After jumping from the door of the plane to a friendly welcome, pilot and crew were invited to take tea at the temple. This they declined. The plane took off and we settled down for an interesting time.

Government in Shilingol was in local hands, considered itself temporary and, for the most part, consisted of members of Prince Te's (Demchukdongruba's) former Meng Chiang government. These officials had the reputation of not favoring one side over the other in the civil war nor of committing themselves to any other government or movement. I suspect they would have welcomed the return of Prince Te as their leader, but this was not actually stated. The Chinese Communist-sponsored Inner Mongolian Autonomous Movement had a representative in the area who was staying at the temple. He was a considerate and knowledgeable young Mongol who seemed to be well liked but not much listened to. He held what seemed then only a remote chance of representing a movement or government that would ensure peace in the region, let alone dominate it.

While at Peitzemiao, we rode camels about twenty miles (twenty $p^{\prime} a o-l i$ ) to visit a Mongolian encampment, one of the closest civilian encampments near the temple at that time. In hindsight, it seems that the family we visited may have been more than usually sympathetic to the arguments of the Inner Mongolian Autonomous representative. The family had lost both husband and father and was in strained circumstances. This impression would not have occurred to someone who had seen poverty in China proper. In comparison, the Mongol family seemed quite well off.

During our visit the son of the Mongol family felt called upon to deliver what seemed an impromptu lecture. He chided the Chinese Communists and their representative for allowing so much power and wealth to remain in the hands of the elite of the Meng Chiang period. The representative appeared embarrassed. He was in no position to make promises, denials, or apologies.

During the academic year of 1947-1948 I was no longer in intelligence. I was enrolled at Fu Jen University in Peiping studying Classical Chinese and spoken Mongolian. In May 1948 I went to Paot'ou as the executive officer of the Paot'ou branch of the China Relief Mission, an interim organization which filled the gap between the demise of UNRRA and the creation of the Economic Cooperation Administration which later came to be called A.I.D. I had several 
reasons for accepting this position. For one, it offered a job and a break from school during the summer months. It also promised to allow me to increase my knowledge of Mongolia while doing something worthwhile. My main reason, though, was more subtle. For the past several years, and especially during the academic year when my contacts had been almost entirely with Chinese, I had come to see situations largely from a Chinese point of view. Through my brief experience with the Mongol way of life the previous year, my studies of the literature on Inner Asia and of the Mongolian language, and my discussions with Mongolian acquaintances, I had begun to realize that one could look at China and Inner Asia from points of view other than those of the Westerner looking at "Orientals" or of the Chinese looking at "barbarians." It was time to qualify my sinification, and so I took this position which would allow me to travel some more in Mongolia.

There existed a very real need for the China Relief Mission in the China of 1948. In many places in North China the 1947 harvest had been inadequate. Spring and early summer of 1948 were lacking in sufficient moisture. It appeared that another crop failure was in the offing. The hardest hit population in the area of Paot'ou were the almost totally agrarian and industrialized Chinese and thus the bulk of relief went to Chinese people. A part of the relief goods, however, had been set aside for Mongols, to be distributed from a small branch station at Paot'ou. We had been able to obtain trucks for transporting grain and other materials. These trucks were specially designed with a very high clearance to enable them to overcome flash floods, dry sand and even quicksand on occasion. They had to be driven from Peiping to Paot'ou by way of the Southern Gate (Nan$\left.k^{\prime} \mathrm{ou}\right)$, through Kalgan and Northwest Shangtu southwest to Kueisui where the trucks and some Mongolian refugees were placed on railroad cars and then shipped to Paot 'ou.

Transporting the trucks to Paot'ou did not take us through Mongolian territory, strictly speaking, although the region leading to and from Shangtu was a border area. The town of Shangtu, the one-time summer capital of Kublai Khan and now largely inhabited by Chinese, was a small town surrounded by a wall which enclosed mostly empty space. Maybe the empty space had at one time been covered by imperial palaces. Now it was used as a place of refuge by Mongols and their flocks from raiding parties. Perhaps the wall had originally been built with this purpose in mind, an alternate means of assuring safety to the flocks of vassals, similar in function to the twin cities built by the Khidat (Chin) deeper in the steppe.

Upon arriving in Paot'ou the great need of the Chinese to the south became very apparent. A grain distribution center was established for this purpose south of the Yellow River for a few days. Expecting people to come to the distribution center proved a hardship for them, so we simply shipped the grain to different points south of the Yellow River which were operated by other relief agencies. Fu Tso-yi, the commanding general of the area, refused to allow refugees fleeing the famine area to cross the river.

Grain, including buckwheat for late spring planting which it was hoped would replace the ruined winter wheat crop, was distributed to the banner administrations or directly to Mongols living on banner lands. Some Mongolian banners were almost entirely pastoral. None were as dependent upon agriculture as the Chinese living in this region, and thus the Mongolian need was not as acute as that of the Chinese. 
During this period I made trips by jeep and truck to most of the Ulanchap and Ordos areas. When distributing grain to Ujin Banner of the Ordos we halfemptied each sack of grain and tied the sacks to the backs of cows which were then herded to the points of distribution. The half-filled sacks balanced well on cow back. We relied on cows rather than on camels for transportation because the Mongols like to rest their camels during the summer, allowing them to recuperate from the winter and to accumulate fat. The men rode horseback. Ujin had no roads because the land was sandy but also as a result of deliberate policy. The absence of roads plus the negative attitude of the banner government helped deter Chinese colonization.

Ujin Banner was the first area where I was personally responsible for relief distribution. It made a deep impression on me. Even though there were no roads the people of Ujin Banner practiced both pastoralism and agriculture. From what I could observe, they lived in well-built houses of Chinese style, open to the swallows which built their nests along the rafters and kept down the fly population. In back or to the side of the baishing, as the Mongols called them, a yurt was generally set up either for storage or to accommodate guests or grandparents. The Mongols preferred goats to sheep here for both milk and wool as they found goat wool of greater commercial value.

As the people of Ujin Banner were both pastoralists and farmers, there was really no rationale for settling Chinese on banner lands. The banner administration allowed the settling of Mongols from other banners to farm Ujin Banner lands while discouraging Chinese encroachment. The movement of Chinese onto banner lands elsewhere was not simply the result of Chinese land hunger, although without this the strategies of both Chinese provincial governors and banner governments could not have been accomplished. The Chinese strategy was to encourage enough Chinese to move onto Mongol lands so that, in due time, the area would come under direct Chinese administration and be incorporated into a hsien, the approximate equivalent to our county.

The Mongolian banner government's strategy was to allow Chinese settlement to a limited extent. This would allow greater income through taxation to the banner government and could be used to increase the banner prince's personal expenditures. I saw a small palace built in the middle of the steppe filled with various gimcracks. These funds also allowed the support of banner schools (cf. Lattimore, The Mongols of Manchuria, 1934). In the long run, these strategies worked to Chinese advantage and the gradual erosion of Mongol control of their lands.

One point which became strikingly clear was that the Mongols, on the whole, had a higher standard of living than the Chinese. The comparison is somewhat difficult to make with regard to housing. A well-built yurt cost as much as an ordinary Chinese house. The frame-built houses, such as those found in Ujin Banner, were of the middle range of Chinese homes. I did not see evidence of extreme poverty in any of the yurts or houses I visited while I had seen a great deal of poverty in Chinese villages. The Mongols dressed better and also ate better than the Chinese.

There was an obvious difference in wealth apparent among the Mongols. A sharp difference existed between the ordinary Mongols and members of princely families and some administrators. So-called palaces were not very elaborate, about on a level with well-to-do Chinese households, if one does not include space and 
buildings used for administrative purposes, the banner school, and space used for markets and workshops. Taking into account differences in subsistence base between the Mongols and Chinese, the one depending on pastoralism and mixed animal husbandry and agriculture, the other dependent on intensive agriculture, the Mongol population was relatively less dense than the Chinese population in China proper. The Chinese living in Mongol areas as farmers, artisans, or merchants appeared well off or even wealthy.

To the north of the Yellow River, where the Meng Chiang government had operated under Japanese auspices, various tactics had been attempted to limit the movement of Chinese onto banner lands and to limit Chinese influence. In one case, lands along the Chinese ethnic border had been given to Mongolian families who were supposed to farm the land, thus creating a buffer zone through which Chinese settlers could not move. In this area Chinese were prohibited from owning banner land. This did not work as planned. The Mongols rented their lands to Chinese farmers and moved further into the steppe with their flocks. In a neighboring banner lands occupied by Chinese were simply cleared of all residents, Mongols and Chinese alike, creating a great habitat for gazelles.

In addition to limiting the influx of Chinese farmers, some banner officials also set about to control the number and occupations of other Chinese allowed to live in the area. In many banners permits had to be obtained for a Chinese artisan or trader to enter Mongol land. Naturally these controls varied. In Ujin Banner trade was reportedly controlled by one Chinese merchant who was making it a lucrative business. In other banners the large temples were the main trading centers. Here access was limited by the banner government and by the frequency of temple fairs. It may well have been too difficult for a trader to wait out the time between temple fairs. In at least one banner, artisans were not allowed to bring their families. By this time, then, the Mongols in most areas tried to control Chinese access to Mongolian lands. The Mongols had obviously realized that there were vastly more Chinese than Mongols. If the Mongols hoped to maintain their identity as a people they had to limit access to their banner lands.

While the Mongols were trying to regulate Chinese colonization of Mongol lands, the Chinese on their part were trying to control the Mongols themselves. The Mongols naturally resisted these attempts. On one level these attempts were mostly to integrate the Mongols into the Chinese socio-political concerns rather than a simple desire to dominate the Mongols. The organization of Mongols into the Chinese Communist sponsored Inner Mongolian Autonomous Movement can be seen in this light as can the efforts made by the Kuomintang to ensure Mongol representation within the party and national assembly.

The younger brother of the former prince of Ujin had reportedly become so engrossed in Kuomintang affairs that he seldom was to be found within the banner, leaving its administration to appointees selected by his brother or, to a lesser extent, to those of his underaged nephew. The princess of Mu Mingan was engaged in a somewhat similar manner in Chinese political affairs, leaving that administration to a relative. An example of a less subtle means of exerting control was to be found at Dsassak Banner where the former prince supposedly had tried to bring the Ordos into the Meng Chiang state. The Chinese Nationalists, not surprisingly, opposed this scheme, put him under house arrest, and placed a more "reliable" brother in charge of banner affairs. 
At a lower level, opium was used to control banner policy. In one case the Nationalists and in another the Communists were said to have ensured a steady flow of opium to key personnel in their efforts to secure policies favorable to them. In still another case, a Kuomintang party representative, a Chinese, had been assigned to a banner in order to enlighten banner personnel about national goals as distinct from the provincial aims of the banner a viernment. This particular very personable individual had, however, found himi elf so much in agreement with the Mongol point of view that he did not dare leave the Mongolcontrolled area for fear of being arrested by the Chinese. There is an equation here. The more a banner administrator was concerned with the welfare of the banner, the more power he had in the banner and the less he had with the Chinese authorities. This was well exemplified in the Alashan, Ordos and in Ulanchap.

My third trip was as a Fulbright scholar in 1949. I entered the Alashan from Lanchow, or rather from Ninghsia, past the crumbling walls of the Hsi-hsia capital and a small city commemorating the fall of the Tanguts and their city. This city, empty now, had remarkably well-preserved walls and gates. After studying Mongolian for several months at Ting-yüan-ying, the capital of the Alashan, I set out by camel across the Gobi to Shan-tan, a trip of nineteen days. I was accompanied on this trip by a young American who was permanently stationed at Shan-tan, working in the Cooperative School, and by two Mongol boys who planned to attend this school in order to learn a trade and other virtues. It was necessary to leave Ting-yüan-ying at this time because we feared the retreat of defeated and disorganized Chinese Nationalist troops pursued by Chinese Communists through this area. I feared that the Chinese Communists would have made me study about Inner Asia from the greater safety of Peiping.

The prince of the Alashan, a cultivated gentleman, spoke little Mongolian but excellent Chinese and some Manchu. His linguistic hybridization had come about because the princely family had been marrying daughters of Manchu noble families for generations, thereby tightening their ties with China, Chung Kuo, the Central Kingdom. People at Ting-yüan-ying had told me that the prince, as a young man, had tried to thwart the power of a Muslim warlord at Ninghsia and had spent several years under detention for his pains.

When I was in the Alashan he had become largely a spokesman for the banner to the Chinese and to Westerners. The banner was meanwhile run by a toslokchi or administrator from a collateral family. The Mongols of the banner were naturally well aware of this sharing of responsibility and gave little credit to the prince. The prince derived his income from lands specifically allotted to him and from hay provided by bannermen for his horses. The Mongols resented this gift, or tax, of hay. The lands allotted to him were actually looked after by his Manchu relatives. The toslokchi, on the other hand, understood little Chinese, had little to do with foreigners, but had allegedly some ties to the Mongolian People's Republic.

These two, dichotomized in terms of responsibility and viewpoint, exemplify the point I made earlier, that the more power a man had in the banner, the less he had with outside powers, especially the Chinese. In the Ordos and the Ulanchap symbols of this dichotomy varied, with language being an important marker. Another was the type of home the leader lived in. In three cases families administering the banner, who were thought of as especially solicitous for banner welfare, lived in yurts. Sometimes they even lived next to a closed "palace" 
which had been built in the past by some relative.

Inner Mongolia in the period 1945-1950 was an area quarreled over by the Nationalists and the Communists. The Mongols were generally not committed to either side but, instead, were committed to Mongolian nationalism. This explains the frequency with which the Mongols changed allegiances in the civil war. I remember one man who when I first met him was affiliated with Ulanfu. Troubled by some of the latter's tactics, he turned to the Nationalists, only to return in time once more to the Inner Mongolian Autonomous Movement.

The Mongols sought three guarantees from the Chinese. One was the right to be represented as a unit in the central government rather than through provincial governors. Another was their right to speak Mongolian and the use of Mongolian as the primary language in their schools. The third was the right to retain banner lands and develop them for their own benefit. The Chinese Communists spoke to all three points while the Kuomintang did not take these asperations seriously. The Chinese Communists have maintained the first two points, but as to the retention of Mongolian lands for Mongols, this seemingly was dropped during the Great Leap Forward and the Great Proletarian Cultural Revolution. The man in Inner Mongolia who best symbolized these Mongol goals was Prince Te.

Before my first trip to Kalgan and Peitzemiao I was quite ignorant about Mongolian issues. I did not become aware of the importance of Prince $\mathrm{Te}$ and his associates until Ulanfu suggested that I had learned of the Wang-yeh-miao meeting from some of them. My friendship with associates of Prince Te strengthened through the years. We decided to increase the understanding of Mongol affairs in the Western world. To this end, we organized a Friends of Mongolia Society. This fledgling organization metamorphosed into the Mongolia Society. Now the Mongolia Society has structure and substance while that earlier association had only the ideal. The Friends of Mongolia initiated the migration of several Mongol intellectuals to the United States. The ultimate success of this venture was due to the backing provided by established American scholars like Lattimore and Lessing.

It was with pleasant surprise and considerable puzzlement that I learned while in Ting-yüan-ying of the impending meeting of Mongols which was to take place there for the purpose of proclaiming an independent Mongolian government. This event which took place in the summer of 1948 was based, I think, on the belief that the civil war would weaken China, thus allowing the existence of an independent Mongolian government. Delegates from different Mongol areas came together but especially associates of Prince $\mathrm{Te}$ and those who had maintained connections with the Nationalists, perhaps only because they lived in regions controlled by the latter at that time. This independent Mongolian government was not sponsored by either the Nationalists or the Communists. Neither had sent an official delegate.

The formation of an independent Mongolian government was based upon several factors. As already stated, the Mongols hoped that a divided China would be unable to control them. Another was a somewhat natural result of dissolving ties between Mongols and Chinese Nationalists, but a reluctance to join the Communist side. Some of the most faithful apologists of the Nationalists could be observed at the meeting as they were in the process of changing allegiances from the now nearly defeated Nationalists to the soon-to-become dominant 
Communists. A third factor was an effort to proclaim to the world that movements for Mongolian independence and autonomy were not simply projections of Soviet, Japanese, or Chinese Communist political maneuverings, but the expression of the wishes of the Mongolian people themselves. Some of the delegates hoped that should Ting-yüan-ying be overwhelmed by Chinese forces, they could first retreat into the Gobi and then make their way to the M.P.R. That is exactly what some of the delegates finally did. The M.P.R. did give most of these Mongols asylum, but there were some tragic exceptions. It must be remembered that the M.P.R. was soon to establish close ties with the Chinese People's Republic, even if these proved to be temporary. Finally, the meeting seemingly took place due to inertia. Men who had been trying to form Mongolian governments ever since 1945, but who had constantly been frustrated in this, went ahead and formed a government even though it dissolved before its functions could be exercised.

My trips to Mongolia were of course not only somber lessons in realpolitik. This was hardly the case. They did force me, however, to realize the importance of ethnicity and of inter-ethnic relations and their influence on intra-ethnic social organization, ideas developed by Lattimore in his Inner Asian Frontiers of China (1951). One of the less somber memories which floats to mind is the crippling effect of riding a camel between thirty and forty miles a day. On that first camel ride the insides of my thighs were rubbed raw by the long strides of the camel. And then I remember the delightfully lonely sound of the long trumpets rising from a lamasery as one nears it at night; or the feeling of homesickness for Chinese things after a month on horseback in Mongol areas; or amusement with a British friend, a journalist, who overindulged in Mongolian summer cheese (a type of half-dried irgen, I believe) which almost did him in. Then there was the relief at recovering from severe sunstroke contracted while setting up a grain distribution center south of the Yellow River. Some wise guy suggested aspirins and whisky until my temperature rose to 104 degrees and a Chinese doctor finally cooled me off. Other memories: the flash of wolf or gazelle in front of vehicle or horse; yurts on the steppe or a lamasery nestled in the foothills; receiving a ceremonial scarf at Edsin Khorö, supposedly the tomb of Genghis Khan; long and earnest discussions with the Chinese who tried to understand the Mongol point of view. And most of all I remember with gratitude the open-handed acceptance of a Westerner by the Mongols, even though he could speak their language only haltingly. 


\title{
THE ROLE OF THE SINO-MONGOLIAN FRONTIER ZONE \\ IN THE RISE OF CINGGIS-QAN
}

\author{
Paul D. Buell
}

Seattle

Crucially important in the rise of Cinggis-qan ${ }^{1}$ seems to have been his close and continued connection with the Sino-Mongolian frontier zone. 2 The connection was significant for him in three ways. First of all, during his earliest years as chieftain, the frontier zone and the frontier system, established by the Chin 金 dynasty (1125-1234) to secure its outer limits and prevent nomadic incursion into China, provided a backdrop against which his Mongol tribal groupings 3 took shape. Second, as Cinggis-qan's influence expanded, the frontier zone, which he conquered in the face of an eroding Chin position, provided a ready-made power base of great potential, one strategically positioned, like a dagger pointed at the heart of China. Finally, as Cinggis-qan laid the foundations for an empire during the period of rapid Mongol expansion after 12ll, the peoples of the frontier zone, mostly mixed societies with mixed cultures based in both the pastoralism of the steppe and the sedentary world of China, provided the experience and expertise needed to get the fledgling structure off the ground. In particular, the peoples of the Sino-Mongolian frontier zone were most important vehicles of Chinese influence upon the Mongols. The form of this influence was subsequently to have the most profound impact upon the shape and development of the political system of the Mongol empire.

\section{Frontier Zone and Frontier System}

In East Asia the second half of the twelfth century was marked by the apogee of the powerful Chin dynasty, founded by the Tungus-speaking Jürced of Manchuria after 1125. ${ }^{4}$ Under the Chin a level of development unattained in North China since the heyday of Northern Sung (960-1125) was achieved. Population exceeded fifty million, 5 industry was well developed, and agriculture reached new plateaus In particular, the century of Chin rule witnessed the culmination of a period of broad agricultural penetration of previously non-agricultural or mixed marginal areas in and around China, including much of the Sino-Mongolian frontier zone. As a result, steppe areas there seem to have been more agricultural in late Chin times than in any period of Chinese history until the coming of the railroads and the great migration of farmers in the late nineteenth century.

At the beginning of the thirteenth century, for example, the registered, sedentary population alone of what is now the Inner Mongolian Autonomous Region seems to have numbered more than one million persons. 6 The non-sedentary population of the area was generally not included on taxation rolls and therefore not included in our sources either.7 The total population of the area was thus probably much higher than one million at that time. By comparison, the total population of Inner Mongolia in 1957, after more than a century of massive migration from the Chinese interior and of industrialization, was only slightly 
greater at 4,200,000 persons, 0.6 percent of a total Chinese population at least seven times larger than that in 1200.8

Evidence from available population data for large-scale penetration of the marginal territories of Inner Mongolia by farmers and other non-pastoral people during this period is fully supported by archeological findings. Inner Mongolia is dotted with ruins from the eleventh and twelfth centuries. Among them are the remains of many small settlements, towns and even small cities, contained within the area protected by the remnants of several lines of outer fortifications constructed by the Chin government in the twelfth century to protect the expanded agricultural areas of its subjects from nomads of the deep steppe (see map). 9

Perhaps the best example of the type of settlement found is provided by the small city known until recently as Olon-süme but now identified with the önggütl0 capital of Tenduc (T'ien-te 天德).11 Although no complete excavation has been undertaken, preliminary surveys indicate that the site, which is a walled settlement about 1,000 by 600 meters containing houses, palaces and even a Catholic church, flourished twice, once around 1200 and again around 1600.12 In other words, the city flourished just when agricultural penetration of the steppe reached its high point on the eve of the Mongol invasion and again in late Ming (1368-1644) times as a new period of Chinese agricultural penetration reversed the trend of a declining population loss in these marginal areas. 13 Systematic surveys of other sites in the area would most likely reveal much the same pattern.14

To secure this expanded agricultural pale the Chin government, as already noted, undertook the construction of a series of fortification lines reaching far out into the steppe, well beyond the traditional Great Wall line. In conjunction with these fortifications the Chin government set about organizing the frontier zone into a frontier system. By the late twelfth century this frontier system comprised three distinct layers, an inner layer made up by primarily Chinese forces based along and behind the Great Wall line, an outer layer consisting of various groups of the steppe proper allied with the Chin, and a middle layer formed by organizational units containing the various inhabitants of the frontier zone itself.

The most important frontier zone inhabitants were what Owen Lattimore has called the "auxiliary peoples of the inner frontier," who as

by-products of the total impact on each other of China as a whole and the frontier as a whole. . . were not genuinely rooted in either the economy and society of China or those of the forested Manchurian mountains, the steppes of Mongolia, or the Tibetan plateau.15

They were, however,

in spite of their limited absolute power. . . of the greatest relative

importance. In passive phases they represented the balance, at any given time, between China and the frontier; but in active phases they were the agents of ferment in frontier relations, causing new adjustments of the balance and preventing it from ever becoming static and permanent.16

In the late twelfth century there were four major..groupings of these "auxiliary peoples" in the frontier zone, the semi-pastoral Önggüt, the nomadic Khitan and Tang'ut and the ethnically diverse bodies known collectively as Jüyin people (Jüyin irgen). 17 


\section{Cinggis-qan and the Frontier Zone}

When Cinggis-qan first associated himself with the Chin frontier system is unclear, but this association was certainly an established fact by the 1190s. At that time the Mongol chieftain, then known as Temüjin, was a close confederate of the Kereyid To'oril-qan, the most important Chin ally in the steppe. In 1196 Temüjin and To'oril campaigned at the behest of the court against a group of recalcitrant Tatars led by one Megüjin-se'ültü. As a reward for their successful efforts To'oril was granted the title ong-qan. (wang $\bar{x}$-qan, "prince qan") and Temüjin was made a ja'ut (sive $\left.c a^{\prime} u t\right)$-quri, 18 a conferral probably expressive of his formal recognition as an allied chieftain by the Chin government. Temüjin seems to have also requested but not been granted the powerful office of frontier military commissioner (chao-t'ao shih 招討使) 19 on the same occasion. ${ }^{20}$

Temüjin's association with Chin frontier organization, in particular his formal recognition as a chieftain by the court, could not have failed to give form and definition to what must have been a rather amorphous following. As a recognized component of the Chin frontier system, Temüjin's following could take on a definite political shape and a more formal "tribal" character just as the institution of the razza, involving the organization of various border communities to fight the enemies of the Faith, greatly helped in the formation of the "tribal" bands of the Seljuq Türkmen.21 This development recalls the fact that in the view of many anthropologists tribes, as the distinct and self-conscious bodies that we visualize them, were not the natural groupings of primitive societies but came into being only when those primitive societies came into contact with more developed societies. In this view, for example, the Germanic tribes noted by Greek and Roman writers were not the natural political formations of the Germanic world but products of contact between the society of the Roman frontier and the Germanic peoples.22 Likewise, the American Indian tribes were products of similar contact or even reservation realities. 23 The apparent role of Chin frontier organization in the definition of Temüjin's following would seem to support this view. ${ }^{2}$

The "tribalization," however, of Temü,jin's followers was of even greater importance than might be readily apparent since it took place at a critical juncture in the history of steppe-sedentary relations. At the end of the twelfth century, just as Temüjin's followers and, for that matter, his superior, To'oril ong-qan, and the many other steppe allies of the court gained new definition and solidity as part of a well-organized frontier system, relationships within and without China began to undergo rapid and extensive changes.

These changes, as well as their causes, differed from place to place. In China itself the crucial factor seems to have been the traditional dynastic cycle of prosperity and collapse which by 1200 saw the Chin regime past its prime and beset by many difficulties. Not the least of its problems were endemic civil disturbances promoted by acrimonious and lengthy disputes over succession to the throne. 25 One result of Chin preoccupations with such internal matters was a relaxation of its control in the Sino-Mongolian frontier zone. At the same time, the frontier zone was the scene of increasing conflict 26 which may have been generated, inter alia, by ecological competition between nomadic and sedentary users of the same lands. 27 In any case, unsettled conditions within China went hand in hand with unsettled conditions in the Sino-Mongolian frontier zone. 
In the deep steppe the weakening of Chin influence soon touched off a major power struggle among leaders formerly allied with and dominated by the Chin court. One great prize in this struggle was control over the frontier zone which a nomadic power could use as a base for adventures in China just as the China-based Chin regime had used it to meddle in the steppe.

Temüjin and his ally To'oril ong-qan, as major allies of the court with wellorganized followers, soon were primed for this great struggle and, as a result, their power and influence grew rapidly after their victory over the Tatars. In 1201 the two allies fought off a powerful league headed by Jamuqa, a former associate of Temüjin, 28 and gained a momentary position of dominance.

Progressive elimination of rivals, however, soon strained relations between Temüjin and To'oril, and in 1203 a second league was formed against Temüjin alone, this time with the participation of To'oril ong-qan. Despite initial difficulties, however, which reduced the future Mongol conqueror's fortunes to their lowest ebb, Temüjin soon mastered the situation and in a series of decisive battles eliminated his enemies or forced them to leave Mongolia. 29 By 1206 none of Temüjin's former rivals remained in a position to influence events, and in that year he gained formal recognition of his power and position through his election as qan, with the reign title Cinggis-qan, by a great assembly (qumiltai) of his family and supporters convened at the headwaters of the Onan river. With his position in the steppe secure, the new Mongol ruler then set about acquiring the prize for his labors, control over the strategic Sino-Mongolian frontier zone.

\section{The Crisis of 120 ?}

The Mongol qan did not have to wait long for his reward for in 1207, only a year after the formal establishment of his power, a large uprising broke out in the frontier zone, an uprising that was to sweep away the last vestiges of Chin control in almost all the territory lying outside the Great Wall line. The primary catalysts in this great uprising were the so-called Jüyin peoples.

In the Ta Chin kuo-chih 大金國志. 30 the role of Jüyin peoples in the revolt is related in the context of the campaigns mounted against Hsi-hsia and Sung of the previous year:

Before this, in the sixth year of T'ai-ho 太和 [1206], the emperor made a general levy of troops to invade the northwest. The various Jüyin

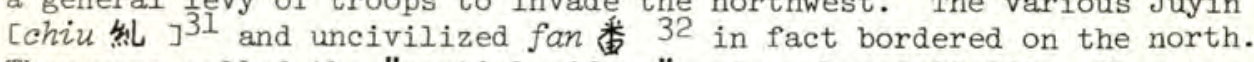
They were called the "martial riders" and numbered 30,000. They were totally mobilized. [The emperor] invaded Chiang-nan江南 [Sung]. Next year the troops were demobilized and peace was reestablished. The various Jüyin were sent back. Because the rewards were not equitable they all revolted and went over to the north. 33

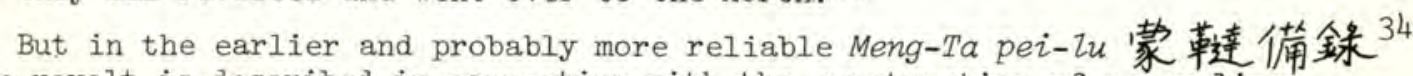
the revolt is described in connection with the construction of a new Iine of fortifications, a line most likely intended to cut off the Jüyin peoples from the deep steppe and to facilitate agricultural penetration of their pastures:

Chang-tsune 章宗 $\left[r_{\text {. }} 1190-1208\right]$. . . then built a new long wall 35 north of Ching-chou people. Their chief's, because the Tang'ut Jüyin had revolted, 
established connections with the Yeh-la tu 邲刺都 Jüyin, ${ }^{36}$ the Mutien 木典 Jüyin, the Mien 咩 Jüyin, the Hou-tien 後典 Jüyin, and others and all revolted. The Chin sent troops to pacify them. The Jüyin people scattered and went over to the Mongols ["Tatar"].37 Here it is specifically the Tang'ut Jüyin, who apparently comprised a major portion of the Jüyin peoples, who are made the leaders of the revolt. But whatever its immediate causes, the uprising led to the Chin court's loss of control over several pivotal and strategically located groupings on its frontiers.

It was apparently in response to the Jũyin uprising that the Chin court attempted a coup against the Tenduc Önggüt, who had long maintained a good relationship with Cinggis-qan without, as far as can be determined, openly breaking with

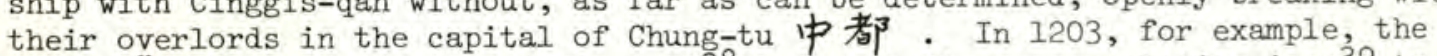
Tenduc Önggüt prince Alaqus-digit-quri 38 had sent his representative Asan 39 to Cinggis with a gift of sables and squirrels, 40 and later that same year he undertook to warn the Mongol ruler against the plans of his rival, Tayang-qan of the Naiman, who had sought unsuccessfully to establish an alliance with Alaqus. 41 As a result Alaqus was recognized as one of the eniliarchs 42 of the Mongol empire, heading a chiliarchy of some 5,000 of his Önggüt, at the time of the great reorganization accompanying Cinggis-qan's election to supreme power in 1206.43 Moreover, in the list of chiliarchs contained in the Secret History the Önggüt prince is called son-in-law (güregen), indicating the first of a long series of dynastic alliances between the Önggüt princes of Tenduc and the Mongol ruling house. 44 With the uprising of 1207 the Chin court could no longer afford to tolerate such a close relationship between the Önggüt and Cinggis-qan and undertook direct action to shape events in its interest.

The fullest account of the Chin coup against the Önggüt is contained in the Ta Chin kuo-chih:

Also formerly there was those [Tatars] ${ }^{45}$ neighboring Chin boundaries. Their chief was established as prince of Pei-p'ing 北平. He was killed. His younger brother succeeded him and was established as prince. The elder brother's son was Po-ssu-p'o 白厮波 and was just two years old. The Great Chin took him up and brought him to the capital. He was brought up in the household of the chiliarch Hei-shui 黑水. In the spring of ting-mao $J$ 仰 , the seventh year of T'ai-ho of Changtsung [1207], the younger brother of the [former] prince of Pei-p'ing presented tribute at Huan-chou 環州. 46 The Chin took advantage of his carelessness and killed him while he was drunk. They reestablished Po-ssu-p'o as prince and sent him back to his country. Before, when Po-ssu-p'o was in the household of the chiliarch Hei-shui, he had seen Hei-shui's daughter and liked her. At this point he wished to marry her. The capital did not allow it. Po-ssu-p'o was grieved and angry and revolted and went over to the Mongols ["Black Tatar"]. 47 They were all the stronger because of this and gradually brought under their control the lands of the various peoples. They consequently mobilized troops to attack Ho-hsi河西 [i.e., Hsi-hsia]. In not many years all the chou $⿻ 川 ⿲ 丶 丶 丶$ and chün 君 48 of Ho-hsi were crushed by them. They got a false 49 imperial princess of the [Hsi] hsia ruling house and departed. The [Hsi] hsia people, on the other hand, served them as tributaries. 50 A textual note then adds that this account refers to the "White Tatars" 51 or Önggüt. 52 
The information in the Ta Chin kuo-chih is supplemented by other sources. From the Persian historian Rashid-ad-Din we learn that the younger brother of the prince of Pei-p'ing killed by the Chin was Alaqus-digit-quri:

The leader (moqaddom) and amir53 of the Önggüt dur:ng the time of Cinggisqan was a person whom they called Alaqus-digit-quri . . He secretly had partiality and inclination towards Cinggis-qan... When Cinggis-qan made an attempt upon China Alaqus-digit harbored a grudge against the Altan-qan [of Chin]54 and therefore yielded Cinggis-qan entry [through the frontier walls]. 55 For this reason Cinggis-qan showed great favor to Alaqus and ordered that a daughter be given him. Alaqus said: "I am old but I had a brother, Binui by name, who was ruler ( $p \bar{a} d s a h) .56$ When he died the Altan-qan of China took his son, Šenkui by name, to China as a hostage. Perhaps you should give this daughter to that one so that it may be that he will come. Cinggis-qan instructed that it would be possible. Alaqusdigit sent a message secretly to his nephew that he would come. He came and when he had reached Kenduk [i.e., Tenduc], 57 which was near to that place, 58 the amirs of his uncle and father sent a message to him saying: "It is not advisable for you to come since your uncle Alaqus would kill you. You keep away until we have destroyed him. Šenkui halted and the amirs of Alaqus-digit killed him. Later Šenkui arrived and entered into the service of Cinggis-qan. 59

In Rashid-ad-Din's account of the assassination of Alaqus the Po-ssu-p'o of the Chinese sources is called Šenkui, nothing more than a Persian transcription of Po-ssu-p'o's Chinese title chen-kuo 錤國, "fortifier of the dynasty, "60 but the description is clearly of the same events narrated in the Ta Chin kuo-chih.

To summarize, in the spring of 1207 the Chin court, alarmed by the great Jüyin uprising that apparently took place during the earlier part of that same spring 61 and the rapid growth of Mongol power in the steppe and probably aware of the Önggüt prince's duplicity, assassinated Alaqus-digit-quri with the active collaboration and cooperation of a faction from within his own followers. But this last-ditch effort on the part of the court in Chung-tu to regain control of the situation on its northern frontiers soon foundered on the unwillingness of Alaqus-digit-quri's nephew and successor Po-ssu-p'o, alias Šenkui, to be the tool of his Chin overlords. He, too, became an ally of Cingiss-qan in that same year of 1207 when "Alaqa-beki [daughter of Cinggis-qan] was given to the önggüt"62 to be the wife of Po-ssu-p'0.63 Thus in this one crucial year of 1207 Cinggis-qan gained control over two pivotal groupings resident in the SinoMongolian frontier zone, the so-called Jüyin peoples and the Tenduc önggüt, and with them dominance over almost the entire frontier zone.

\section{The Frontier Zone as Base}

After 1207 the whole relationship between the steppe and China changed since it was now the Mongol qan who increasingly assumed a position of dominance and pushed his own organizational system deeper and deeper into the sedentary world just as the Chin court had formerly expanded its own influence and its frontier system far into the steppe world.

The first expression of the changed relationship was the Mongol advance against the Hsi-hsia capital in 1209-121064 but the following year the great raids against the Chin heartland began. They ended in the first Mongol siege of Chung-tu in 
1214 and the subsequent removal of the Chin court south to K'ai-feng 開封 and the comparative safety of the Yellow river, an event marking the virtual abandonment of almost the entire northern portion of the Chin empire to the steppe conquerors. Most raids and campaigns of these years were mounted from or through the Sino-Mongolian frontier zone, and it was Mongol possession of this strategic area, more than anything else, which forced the Chin to move their capital. 65

By 1214 the conquerors felt strong enough not only to raid but also to begin a piecemeal conquest of North China with the former Chin capital of Chung-tu itself which fell in the spring of 1215 to a force comprised largely of local allies of the Mongols. 66 During the years of conquest the Sino-Mongolian frontier zone continued to play a most important role.

As I have shown elsewhere, 67 throughout much of its existence the Mongol empire was structured and ruled as a gigantic tribal federation. Its various provinces, including Mongol China, first emerged as little more than regional outgrowths of this great tribal structure, as branch federations of the main federation of the steppe.

To rule such branch federations certain chiliarchies of the Mongol levy were associated with various reliable local elements to form a tanma, "nomadic garrison force," 68 and stationed in or as near to the territories of the branch federation as possible. In the case of Mongol China, the tanma, organized in 1217 or $1218^{69}$ under Muqali,70 was centered in the Sino-Mongolian frontier zone which thereby became, and remained for almost the entire period of imperial rule, the military and organizational center of Mongol domains in China.71

But the frontier zone was more than just a physical and logistical base for Mongol power in China. Imposition of a tribal system of rule did not preclude or prevent development of bureaucratic elements as well. As time passed the utility and productiveness of local methods for governing and exploiting a given local area became all too clear for many influential Mongols. For China and other more developed portions of Mongol domains, local methods were generally local bureaucratic methods. This fact, coupled with the effects of changes taking place within Mongol society itself, soon gave rise to a gradual but definite "bureaucratization" of Mongol rule that ultimately culminated in the largely bureaucratic administrative structures of the various successor qanates after the breakup of empire.72 The process of "bureaucratization," however, created problems for the comparatively primitive Mongols who lacked adequate sources of the new kind of administrative talent within their own ranks and were forced to turn to the conquered peoples to provide the bureaucratic administrators necessary for ruling themselves. In China, the various nationalities of the SinoMongolian frontier zone, with their experience in both the pastoralism of the steppe and the sedentary traditions of China, proved culturally and politically a particularly acceptable and reliable source of talent for the conquerors. Consequently, as conquest continued inhabitants of the frontier zone performed an increasingly important function in the day-to-day administration of the areas brought under control.

Typical of the many administrators from the frontier zone in Mongol service during the early years of the empire, although in his special case the association was by reason of ancestral culture rather than of actual residence, was the Khitan Yeh-lü Ch'u-ts'ai 邲律楚材 (1189-1243).73 Entering Mongol service in the aftermath of the fall of Chung-tu and the virtual collapse of Chin authority 
in much of the Chin empire, he first held office as a court astrologer, in which capacity he created a Chinese-style calendar for court use, then as state secretary (bicikci)74 for Chinese affairs in the imperial chancellery and finally under qan ögödei (r. 1229-1241), son and successor of Cinggis-qan, as head of the imperial tax system for occupied China that was largely organized in accordance with the Khitan's own proposals to the qan.75

In all his various roles Yeh-lü Ch'u-ts'ai was instrumental in introducing Chinese administrative practices and Chinese institutions among the Mongols, thereby considerably enhancing the overall effectiveness of Mongol government at all levels. Clearly the Khitan was one of the most important cultural mediators between the Mongols and China and the early decades of Mongol rule there. Significantly, however, the Chinese administrative practices and institutions which Yeh-lü Ch'u-ts'ai, and many others like him, transmitted were not passed on unchanged. Rather they reflected the particular cultural environment peculiar to the transmitters themselves, namely the mixed, semi-Sinified environment of the Sino-Mongolian frontier zone. 76

In conclusion the Sino-Mongolian frontier zone was very important for the Mongols. It began as the backdrop against which the Mongol tribes of Cinggisqan took shape and it later became the springboard for the Mongols' conquest of China. Finally, when the process of conquest itself was complete the people of the frontier zone became important cultural intermediators guaranteeing rule just as Mongol arms guaranteed conquest.

\section{Notes}

1. Mongolian names and terms are given in their Middle Mongolian forms transcribed according to the system employed in Igor de Rachewiltz, Index to the Secret History of the Mongols, Uralic and Altaic Series, v. 121 (Bloomington, 1972).

2. By Sino-Mongolian frontier zone I am referring to an area approximately equivalent to contemporary Inner Mongolia. See map.

3. By "tribal grouping" or "tribe" I am referring to what Sahlins calls a "chiefdom." See the discussion in Marshall D. Sahlins, "The segmentary lineage; an organization for predatory expansion," American Anthropologist 63 (1961), pp. $322-345$.

4. For a survey of Chin history see the study by M. V. Vorov'yev, Chahurchaheni $i$ Gosudarstvo Tszin' (Moscow: Nauka, 1975).

5. On the population of China at the time of the Mongol invasions see Ho Pingti, "An estimate of the total population of Sung-Chin China," in F. Aubin, edi-

tor, Etudes Song, Series I, I (1970), pp. 33-53.
6. According to figures given in the Chin shih 金史 (Peking: Chung-hua shuchü 中華書局, 1975; henceforth CS), chuan 24, pp. 557-569, there were approximately 150,000 families or about 850,000 persons, assuming an average
family size of 5.5 , registered in those parts of Hsi-ching $2 u$ 西京路 outside family size of 5.5, registered in those parts of Hsi-ching $2 u$ 西京路 at the beginning of the thirteenth century. The breakdown is as follows:

$$
\begin{aligned}
& \begin{array}{l}
\text { Feng-chou 豐州 } \\
\text { Ching-chou } \\
\text { Huan-chou 榣州 }
\end{array} \\
& \text { Hsi ching } \mathrm{Zu} \\
& \begin{array}{r}
22,683 \text { families } \\
5,938 \text { families } \\
578 \text { families }
\end{array}
\end{aligned}
$$



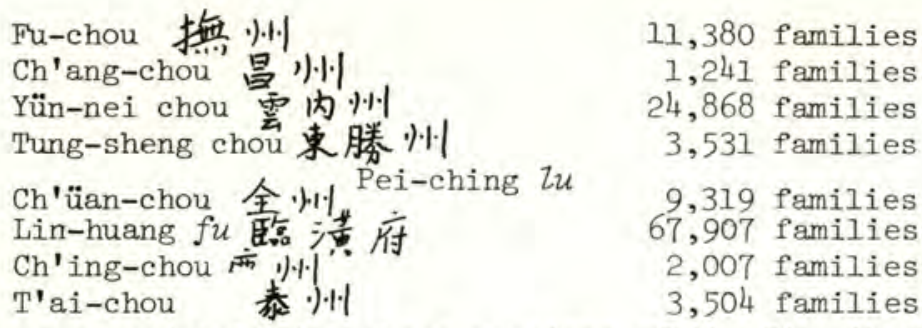

The number of persons inhabiting those portions of the Sino-Mongolian frontier zone controlled by the Tang'ut of Hsi-hsia is not known with certainty, but if population densities in the Hsi-hsia border areas were approximately the same as those in Chin domains, about 20,000-30,000 families or 110,000 to 165,000 persons lived in the Hsi-hsia portions of the frontier zone. We may thus estimate the total registered population of the frontier zone to have been about one million at the turn of the thirteenth century.

7. On the basis of Chin population registration see Ho, op. cit. That tribal population was generally not included in the 1207 canvass (the basis of the CS figures) is clear from such things as the low total ( 578 families) for Huan-chou, an area known to have a large Khitan, i.e., tribal, population. The so-called Minggan-müke census of 1187 recorded a total of some 127,544 persons within the jurisdictions of the Jüyin units (see the discussion in Ho) and it is unlikely that any of these appear in the figures from the 1207 canvass.

8. This figure for 1957 is from the U.S. Central Intelligence Agency, People's Republic of China: Atlas (Washington, 1971), p. 37. It is an estimate based on the results of the 1953 census. Ho, p. 51 gives a total population of about 110,000,000 for China in 1200.

9. On these "reservoir walls" see Owen Lattimore, "Origins of the Great Wall of China: A frontier concept in theory and practice," in his Studies in Frontier History (London: Oxford University Press, 1962), pp. 97-119, henceforth Lattimore 1962a.

10. On the Turkic-speaking Önggüt see Sakurai Masuo 擝井育雄, "Ōko buzoku ko" 汪古部族考, Toho gakuho 東方祭教 6 (1936), pp. 659-680; Paul Pelliot, Recherches sur les Chrétiens d'Asie Centrale et d'Extrême Orient (Paris: Imprimerie Nationale, 1973), pp. 239-288; and Owen Lattimore, "A ruined Nestorian city in Inner Mongolia," in his Studies in Frontier History, pp. 221-240, henceforth Lattimore $1962 b$.

11. On Olon-süme see Pelliot; Lattimore 1962b; Walther Heissig, Ein Volk sucht seine Geschichte (Düsseldorf and Vienna: Econ Verlag, 1964), pp. 282-295; and Namio Egami, "Olon-Sume et la découverte de l'église catholique romaine de Jean de Montecorvino," Journal, Asiatique 240 (1952), pp. 155-167.

12. See Heissig, pp. 282-295.

13. On Ming attitudes towards their northern frontiers see the discussion in Edward L. Farmer, Early Ming Govemment: The Evolution of Dual Capitals (Cambridge: Harvard University Press, 1976), pp. $86 \mathrm{ff}$. and passim. However, to a large extent, the growth in the number of cultivators in Inner Mongolia in the sixteenth and seventeenth centuries was more a reflection of growing Manchu rather than Ming influence. On this period see Franz Michael, The Origin of Manchu Rule in China (Baltimore: The Johns Hopkins Press, 1942).

14. See Heissig, p. 288.

15. Lattimore 1962a, pp. 115-6.

16. Lattimore 1962a, p. 116.

17. On the Jüyin peoples see Wang Kuo-wei王國維, "Yüan-ch'ao pi-shih chih 
chu-yini-erh-chin k'ao"元朝秘史之主因亦兒緊考，Shigaku zasshi 史學卒隹誌 38: 5 (1927), pp. 1-15, henceforth Wang 1927.

18. For a discussion of this title see G. Doerfer, Türkische und mongolische Elemente im Neupersischen, vol. I (Wiesbaden: Franz Steiner Verlag, 1963), pp. 282-3; and Paul Pelliot, Notes on Marco Polo, vol. I (Paris: Imprimerie Nationale, 1959), pp. 291-295.

19. Under the Chin there were four chao-t'ao shih, each assigned the duty of subduing rebels and resisting external assault in a given jurisdiction.

20. These events are recounted in the following terms in the Secret History (chuan 134): "Cinggis-qahan and To'oril, the two of them, went to meet Onggingcingsang saying that they had killed Megüjin-se'ülte. Ongging-cingsang, rejoicing greatly after he had learned that it had turned out that they had killed Megüjin-se'ültü, when he gave the title ja'ut-quri to Cinggis-qahan he then gave the title ong to To'oril of the Kereyid. The title ong-qan thus arose from Ongging-cingsang's title giving. When Ongging-cingsang spoke he said: 'Your attacking and killing of Megüjin-se'ülte has been a very great assistance to the Altan-qan. I wish to report to Altan-qan this assistance of yours. The enhancement of the title greater than this for Cinggis-qahan, the giving of the title jeutau [chao-t'ao] to him, Altan-qan must see to.' After that Ongging-cingsang immediately returned, rejoicing. Cinggis-qahan and the Ong-qan, the two of them, having made captive, divided and carried off the Tatar together, returned to their yurts and camped." The Ongging-cingsang, or Wan-yen ch'eng-hsiang 完颜 丞相, mentioned in the text is apparently Wan-yen Hsiang 完颜睘, the Chin official in charge of frontier operations during the campaigns against the Tatar. On the campaigns themselves see the discussion in Wang Kuo-wei, "Ta-ta k'ao"莲靼考, in his Meng-ku shih-liao ssu chung 蒙古史料四種 (Taipei: Cheng-chung shu-chü, 1962), henceforth Wang 1961, pp. 584-600.

21. See the discussion in Claude Cahen, "La première pénetration turque en Asie-Mineure," Byzantion 18 (1948), pp. 5-67.

22. See the discussion in E. A. Thompson, The Early Germans (Oxford: Clarendon Press, 1965).

23. See Morton H. Fried, The Evolution of Political Society (New York: Random House, 1967), pp. 170-174.

24. For a general discussion of what I call the process of "tribalization" in late twelfth and early thirteenth-century Mongol society see also Paul D. Buell, "Tribe, Qan and UTus in Early Mongol China: Some Prolegomena to Yüan History," unpublished doctoral dissertation, University of Washington, Seattle, 1977 (order number 7800908), henceforth Buell 1977, pp. 26 ff.

25. On late Chin history see Tao Jing-shen, The Jürchen in Twelfth-Century China (Seattle: University of Washington Press, 1976), pp. 84 ff.

26. The Jüyin uprising of 1207, discussed below, was only one of many similar revolts. In 1201, for example, the Khitan Yeh-lü Te-shou led his people, numbering several myriads, against the Chin overlords who mobilized an even larger force in suppressing the rebellion (see Yü-wen Mou-chao 宁文棂昭, Ta Chin kuochih, Kuo-hsüeh wen-k'u 國然文庸, henceforth TCKC, chuan 20, p. 14). See also Wang 1961, pp. $581 \mathrm{ff}$. for a recitation and discussion on Chin involvements on and beyond its northern frontiers.

27. On the role of similar conflict in the rise of the Kalat qanate of Baluchistan see Nina Swidler, "The development of the Kalat khanate," in W. Irons and N. Dyson-Hudson, eds., Perspectives on Nomadism (Leiden: E. J. Brill, 1972), pp. 115-121, and her unpublished doctoral dissertation, "The Political 
Structure of a Tribal Federation: The Brahui of Baluchistan," Columbia University, 1969.

28. On Jamuqa and his conflict with Cinggis-qan see Sh. Natsagdorj, ed., Bügd Nayramdax Mongol Ard UZsyn Tü̈̈x, vol. I (Ulaanbaatar, 1966), pp. 203 ff.

29. On the history of this period see Sh. Natsagdorj, pp. 167-214.

30. The Ta Chin kuo-shih purports to be a private history written by the Jürced scholar Yü-wen Mou-chao and presented to the Chin court shortly before the fall of the dynasty. In its present form, however, the work is clearly a product of the period after the fall of $\mathrm{K}^{\prime}$ aifeng to the Mongols in 1234. Whatever the history of the text, the Ta Chin kuo-chih contains much useful material on the rise of the Mongols and the last years of Chin rule, much of its information drawn from sources now lost.

31. On the equivalency of chiu and the Jüyin of the Secret History see the discussion in Wang 1927.

32. Fan has two meanings in texts of the period. One is simple "barbarian tribes" but the other is specifically "Tang'ut barbarian tribes." The word is possibly used here in its second sense, probably in reference to Tang'ut allies of the Chin not included among the Jüyin.

33. TCKC, chuan 21, pp. 22-23.

34. The Meng-Ta pei-lu is an account of a Sung mission to the Mongols of 1220 composed the following year by one Chao Hung 趙珙, a member of the mission.

35. On the Chin frontier walls see above and note 9.

36. The character tu which means, among other things, "chief," may be interpreted here to mean that this Jüyin had a controlling role with respect to the others. The Yeh-la, incidentally, were the former royal lineage of the Khitan.

37. Chao Hung, Meng-Ta pei-lu, in Wang Kuo-wei, ed., Meng-ku shih-liao ssu chung, pp. 448-9. For a complete list of the Jüyin peoples allied with the Chin see the CS, chuan 24, pp. 570-571.

38. For his biography see the Yüan shih 元史 (Peking: Chung-hua shu-chü, 1976), henceforth YS, chuan 118, pp. 2923-4, and Su T'ien-chüeh 蘇 天爵, Ÿ̈an wen-lei 元文颣, Tu-shu cha-chi ts'ung-k'an, henceforth YWL, chuan 23, pp. 20-21.

39. This name possibly represents the Islamic Hasan.

40. Secret History, chuan 182. All citations of the Secret History, henceforth $S H$, are to the de Rachewiltz edition in de Rachewiltz, op. cit.

41. SH, chuan 190. See also the account of these events in the YWL, chuan 23, p. 20, and in Rashỉd-ad-Din's Jomi' al-Tavāa $\bar{\imath} x$, edited by A. A. Romaskevicha,

A. A. Khetagurova and A. A. Ali-zade (Moscow, 1968), henceforth JAT, p. 309.

42. On the significance of the chiliarchy and the chiliarch for the early Mongol empire see the discussion in Buell 1977, 2oc. cit.

43. SH, 202. Note the variable size of a "chiliarchy."

44. The history of the marriage alliances between the house of Alaqus and that of Cinggis-qan is complicated. See the detailed discussion in Buell 1977 , pp. $45 \mathrm{ff}$.

45. "Tatar" was used in texts of the period in reference to a variety of Altaic-speaking peoples. These "Tatar," of course, were Önggüt.

46. For the Huan-chou of the text read Huan-chou 桓州, the more common form of this place name.

47. To distinguish between the various "Tatar" the Önggüt were sometimes called "White Tatar" and the Mongols and their like "Black Tatar." 
48. Chou and chün were obsolete administrative units. They are used here simply in the sense of "territories."

49. The wei傜, "false," of the text implies the illegitimacy of the Hsihsia ruling house.

50. TCKC, chuan 22, pp. 27-28. An almost identical account is found in Li

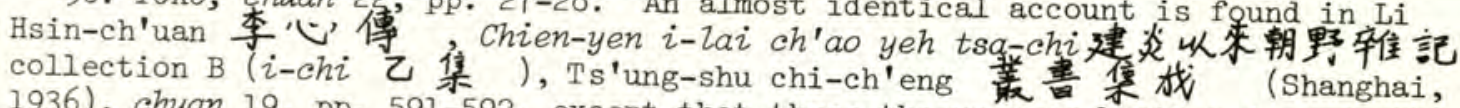
1936), chuan 19, pp. 591-592, except that there the younger brother is made the murderer of the elder brother, whose name is given as She-shu 鼬叔, and the date of the murder is given as 1190. None of this additional information conflicts directly with the testimony of the TCKC or that of other sources with the exception of the name assigned the elder brother, given as Binui in the JAT, p. 310. Quite likely, however, She-shu is not a name but a title since the younger brother, whom we know to have been Alaqus, is also called She-shu in Li Hsinch'uan's version of the events.

51. See note 47 .

52. TCKC, chuan 22, pp. 27-28.

53. In Rashid-ad-Din's usage an amir was usually a chiliarch or some such similar potentate.

54. This was the Mongolian name for the Chin ruler. On altan, "golden, imperial," see Henry Serruys, "Mongol altan 'gold' = 'imperial, " Monumenta Serica

55. In Rashid-ad-Din the Onggüt are made guardians of the frontier walls for the Chin and their name is connected with a hypothetical öngü, "frontier wall." See the discussion in Doerfer, pp. 152-153. In fact, this conception is based upon a misunderstanding of the nature of Chin frontier defenses at that time which nowhere had the solidity or completeness of the Great Wall of Ming times, for example. Nonetheless the tradition does do justice to the strategic importance of the Önggüt whose territories could be an important base for nomadic assault or a first line of defense against nomadic incursions. The campaign mentioned here, however, was not directed against the Altan-qan of Chin but against Hsi-hsia, first raided by the Mongols on a large scale in 1205. For a history of Mongol raids and wars against Hsi-hsia see Ye. I. Kychanov, "MongoloTangutskiye voiny i gibel' gosudarstva Si Sya," Tataro-Mongoly v Azii i Evrope (Moscow: Izdatel'stvo Nauka, 1977), pp. 46-61.

56. Note the careful distinction made between Alaqus' position among the Önggüt and that of his elder brother Binui. Quite probably Rashid-ad-Din's informant did not recognize Alaqus as legitimate ruler of the Önggüt. Tenduc.

57. The manuscript tradition favors "Kenduk" but this is clearly an error for

58. Something has fallen out of the text at this point since the "place" in question is not named. Reference is probably to some other önggüt city where Alaqus had his (seasonal?) residence at that time.

59. JAT, pp. 308-310.

60. This is the title under which Po-ssu-p'o occurs in the YS (chuan 118, p. 2924) and the YWL, chuan 23, p. 21.

61. The date of the Jüyin uprising is not given exactly and our sources only record that it was in the year after 1206. Most Jüyin elements, if not all, however, were exclusively pastoral and it was easiest for pastoralists to go on campaign during the slack season of late autumn and winter when work was light and reserves of food readily available. The spring, on the other hand, was lambing time, demanded intensive labor and was a period of tight food supplies 
and frequent famine. If the Jüyin people were mobilized in 1206 it was most likely during the autumn and their demobilization probably took place during the early spring of the following year, in time for lambing. Their revolt must have taken place at about the same time, when environmental pressures were greatest.

62. $S H$, p. 239.

63. See the discussion in Buel1 1977, loc. cit. cit.

64. On the Mongol campaign of 1209-1210 against Hsi-hsia see Kychanov, op.

65. On the Mongol wars against the Chin during the time of Cinggis see H. Desmond Martin, The Rise of Chingis Khan and his Conquest of Northem China (Baltimore: The Johns Hopkins Press, 1.950).

66. See the account in the Sheng-wu ch'in cheng $Z_{u}$ 聖武親征金录， in Wang Kuo-wei, ed., Meng-ku shih-liao ssu chung, pp. 170-174.

67. See Paul D. Buell, "Kalmyk Tanggaci people: Thoughts on the mechanics and impact of Mongol exparsion," Mongolian Studies 6 (1979), forthcoming, henceforth Buell 1979.

68. See the detailed discussion of the tanma as an institution in Buell 1979.

69. There are two dating traditions, a Mongolian and a Chinese. It is uncertain which is correct.

70. On Muqali see his YS biography in YS, chuan 119, pp. 2929-2936.

71. On the organization and history of the China tanma see Buel1 1979.

72. See the detailed discussion of this thesis in Buell 1977.

73. On Yeh-lü Ch'u-ts'ai see his biography in the YWL, chuan 57, pp. 9-24, and in the YS, chuan 146, pp. 3455-64. On his role in early Mongol China see N.Ts. Munkuyev, Kitaiskii Istochnik o Pervykh Mongol'skikh Khanakh (Moscow, 1965), pp. 3-129, and Igor de Rachewiltz, "Yeh-lü Ch'u-ts'ai (1189-1243): Buddhist idealist and Confucian statesman," in Arthur F. Wright and Denis Twitchett, eds., Confucian Personalities (Stanford: Stanford University Press, 1962), pp. 189-216.

74. For a full discussion of the office of the bicikci see Sechin Jagchia, "Shuo Yüan-shih chung ti 'pi-she-ch'ih' ping chien-lun Yüan ch'u ti' chung-shu-

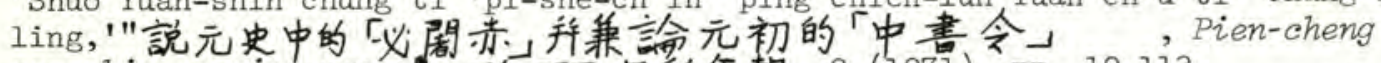
yen-chiu so nien-pao 透政研究所年報2 (1971), pp. 19-113.

75. For a discussion of this tax system and the role of the Khitan minister in its creation and administration see Buell 1977, pp. $82 \mathrm{ff}$.

76. See the detailed discussion of this phenomenon in Buell 1977. 


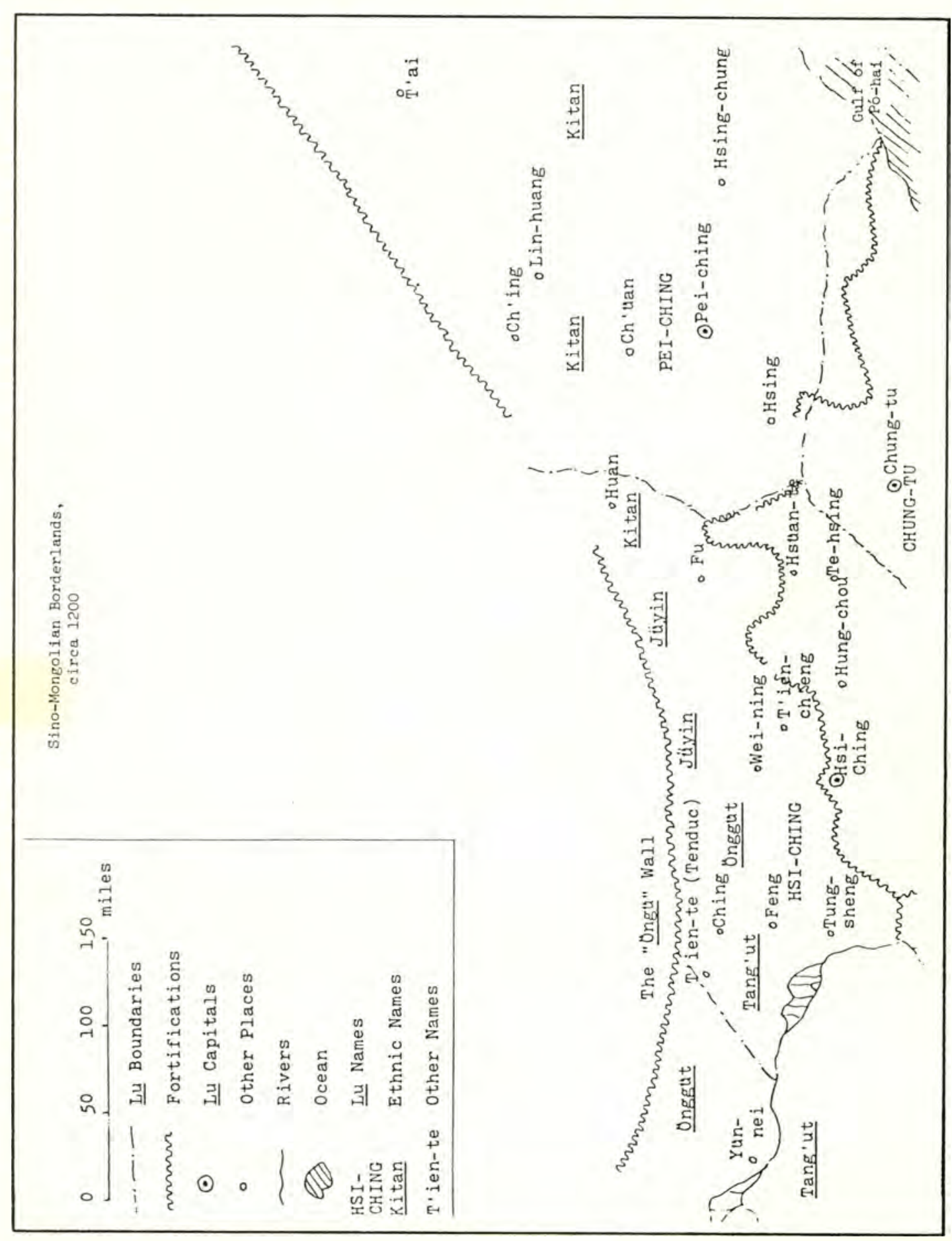




\title{
TIBET AND MONGOLIA IN THE SEVENTEENTH CENTURY: THE NATURE OF A SPECIAL RELATIONSHIP
}

\author{
Alicia J. Campi \\ Indiana University
}

When examining the panorama of Central Asian history after 1000 A.D., it quickly becomes evident that the histories of Mongolia and Tibet are significantly intertwined. Both nations have been faced with the unending task of preserving their unique cultures in the shadow of the Chinese giant, and both have been remarkably successful up until the modern era. I Sharing a common problem with a common protagonist, Mongolia and Tibet have often joined forces-usually in the form of Mongol political and military might interlocked with Tibetan cultural and religious dynamism--for their mutual as well as particular self-interests.

This examination of the "Mongol protectorate" in Tibet during the midseventeenth century is an effort to place this experience within the repeated pattern of Mongolian-Tibetan relations. Always on the horizon is China, so this study must also concern itself with the catalytic role played by concurrent events in the Middle Kingdom. This does not mean, however, that Mongolia and Tibet created their foreign policies solely in reaction to Chinese stimuli. On the contrary, much of the evidence reveals that Mongolian and Tibetan internal politics determined the ultimate direction of their special relationship.

To understand the nature of the special relationship forged between Mongolia and Tibet during the seventeenth century, one must look first at alliances established by Qubilai Qan and the 'Phags-pa Lama and by Altan Qan and the Third Dalai Lama. In addition, examining the unique example of Mongol-Tibetan cooperation in the person of the Fourth Dalai Lama is vital to comprehend the subsequent events of the seventeenth century in Central Asia. After briefly discussing these three historical precedents, we can then turn in more detail to the establishment and functioning of Gushi Qan's Mongol protectorate in Tibet and partnership with the Fifth Dalai Lama in the 1600s.

\section{Qubilai and the 'Phags-pa Lama}

Although hit by the shock wave of the Tanguts' defeat at the hands of Chingis Qan in 1207, the Tibetans themselves did not have to contend with the Mongol armies until 1240 when Prince Köden sent a military force from his Kokonor base into Tibet proper as part of the Mongol strategy to outflank the Sung armies. Faced with the sacking and burning of monasteries north of Lhasa, the Tibetans sent the abbot of the Sa-skya sect to negotiate with the Mongol prince. The parties agreed that Tibet would acknowledge Mongolian suzerainty and pay a fixed tribute, and that the Sa-skya leader should become the Mongol representative in Tibet. The Mongols sent tax collectors to supervise the payment of tribute, while the Sa-skya Pandita remained in Köden's camp as a well-treated hostage. 
An insurrection by the Tibetan nobility in 1251 was suppressed by Mongol troops, thus ending effective Tibetan armed resistance to Mongol arms. 2 The Sa-skya Pandita's nephew, 'Phags-pa Blo-gros (1235-80), grew up as a hostage and was educated at Prince Köden's Kokonor court, assuming his uncle's place as abbot of Sa-skya in 1251.3 The newly enthroned Mongol emperor Qubilai, who had met 'Phags-pa Blo-gros in the Köden court years before, made the 'Phags-pa Lama his kuo-shih 成官币, "national mentor," in 1260. At the Mongol imperial court the 'Phags-pa Lama devised a Tibetan-derived script for the Mongol language and propagated Buddhism among the Mongol nobility. Qubilai bestowed upon him another title, ti-shih 帝启 "imperial mentor," and patronized the Sa-skya sect in its power struggles with other Buddhist schools in Tibet.

The Sa-skya sect needed Mongol military assistance to maintain its dominance over rival sects contending for power in Tibet. Like the protectorate of Korea, Tibet proper was never occupied by Mongol troops. Rather, the Mongol army would come in to aid the Sa-skya in specific crises, such as the rebellion at the ' $\mathrm{Bri}$ gung monastery in 1290. The Mongols set up a native government in Tibet to watch out for their interests and to maintain control of internal affairs--a policy the Mongols were to use in many places throughout their empire.

Significantly, the Sa-skya school customarily divided power between the spiritual leader or abbot, e.g. 'Phags-pa, and the secular authority or regent known as the Dpon-chen, e.g. the 'Phags-pa's brother. In theory these two were equal in rank with two distinct functions. The Tibetans took this theory and applied it to the relationship they had just formed with the Mongols. Thus the 'Phagspa Lama was the spiritual leader of the Mongol empire, and Qubilai or any Mongol emperor was the temporal regent, sharing power equally. In reality, Qubilai and the Mongols saw themselves firmly in control over the entire empire. Nevertheless, the fiction of the spiritual equality of the Sa-skya abbot fit their purposes as rulers over vast populations in East Asia which adhered to one school or another of Buddhism. To be sure, members of the Mongol nobility were committed converts to the Buddhist faith, but the shamanistic Mongols throughout the Yüan court saw significant political gains in maintaining the theory of a Tibetan Buddhist sharing power and thus lending legitimacy to the non-native Yüan government in China. The Mongols did appoint their own Mongol damgachi with nominal authority over the Sa-skya Dpon-chen to supervise Tibetan governmental affairs. However, the Tibetan Dpon-chen in point of fact governed Tibet for the Mongols instead of his theoretical superior, the Mongol darugachi. 4

\section{Altan Qan and the Third Dalai Lama}

With the weakening of Mongol control in China and Inner Asia, reaction set in against foreign domination and the Mongol-allied Sa-skya sect. Rival sects assumed power in Tibet and the Sa-skya, without strong Mongol military support available, lost their position of control. However, the relationship between Qubilai's court and the Sa-skya was to be the model for Altan Qan of the Tümed and Bsod-nams Rgya-mtsho, the Third Dalai Lama, at their famous meeting in 1578.

The participants in this new drama were quite different from those of two centuries earlier. The Mongols had lost their empire and been replaced in China by a native dynasty, the Ming. The tribes on the Mongolian steppe, while still an effective military power, were disunited and at war with each other more than 
with the Ming enemy. In Tibet, the Sa-skya had declined in political power and was no longer an important force in national politics. Power now lay with the Rin-spungs-pa of Gtsang, who patronized the Karma-pa sect. In the early fifteenth century the reformed Dge-lugs-pa sect, often referred to as the Yellow Hats, was founded by Btsong-kha-pa. By the time of Altan Qan this sect, imbued with evangelistic and political spirit, was competing with the Karma-pa and the many other sects in Tibet for religious and political supremacy. There were military clashes between Dge-lugs-pa and Karma-pa adherents, until with the rise of the kings of Gtsang, Dge-lugs-pa lamas were circumscribed in their activ-
ities. 5

The Tibetan sects of the late sixteenth century were different, yet the antagonism and competition found then was very reminiscent of the situation in Tibet prior to the first Mongol intervention in 1240 , and the fundamental problems encountered by Tibet and Mongolia were remarkably similar. In Tibet religious factions struggled for political power, but no sect was sufficiently strong to vanquish its opponents. Concurrently, on the Mongolian steppe various claimants for power still faced the key question of legitimacy. Altan Qan in the latter part of the 1600s sought to reassert the supremacy of the Eastern Mongols over the Oirad or Western Mongols, claiming that he was the legitimate successor of the Chingissids. He, with his grand-nephew Qutugtai Secen Qungtaiji of the Ordos, had extended their power over most of Mongolia. contentious rivals threatened the establishment of a unified state.

It is recorded in the Erdeni-yin Tobchi that Qutugtai Secen Qungtaiji invaded Tibet in 1566, sending messengers to the heads of various monasteries "offering to accept their religion if they submitted and threatening to treat them as enemies if they did not." 6 This incident can be interpreted as a raid for empire-building or perhaps a scouting expedition at Altan Qan's behest.

Why Altan Qan invited the Dge-lugs-pa leader, Bsod-nams rgya-mtsho, to Mongolia is not clearly understood. Traditional Buddhist histories credit this event to Altan Qan's conversion to that religion in 1571. The qan's first invitation to the Dge-lugs-pa head in 1574 was declined. 7 Two years later Sagang Secen indicates that Qutugtai Secen Qungtaiji visited Altan Qan and reminded him that "for the well-being of this and the future life," religion was necessary. 8 Mention was made of following the example of Qubilai and the 'Phags-pa Lama. Therefore a second embassy was sent to the Dge-lugs-pa Lama which he accepted. At the meeting between these two men in Mongolia in the summer of 1578 titles were exchanged, i.e. Altan Qan conferred the title Dalai Lama on Bsod-nams Rgya-mtsho, and the conscious emulation of the Qubilai-'Phags-pa Lama precedent was emphasized. Zahiruddin Ahmad has compared the account of Sagang Secen with that of the Third Dalai Lama.9 The Third Dalai Lama's Rnam-thar (Biography) says that Altan Qan identified himself as Qubilai. Sagang Secen states that Bsod-nams Rgya-mtsho claimed that Altan Qan and he were reincarnations of Qubilai and the 'Phags-pa Lama.

These sources appear to reveal Altan Qan's motivations for the invitation to the Third Dalai Lama. Altan Qan and his grand nephew, Qutugtai Secen Qungtaiji, were seeking to prove their right to re-establish the Mongol empire, for if the 'Phags-pa Lama had been reborn in the Third Dalai Lama, Altan Qan then was the reincarnation of Qubilai. As for Bsod-nams Rgya-mtsho's motivations for accepting the invitation, surely missionary zeal was a factor, but the political 
realities of the Tibetan scene lead me to conclude that he wanted to attract a Mongol patron to guarantee his own success at home.

The "alliance" created by Altan Qan and the Third Dalai Lama drew the Mongols directly into the religious politics of Tibet and likewise expanded the religious struggle between the Dge-lugs-pa and the Karma-pa sects into the new arena of Mongolia.10 Because his patron, Altan Qan, had died in 1582, the Third Dalai Lama visited Mongolia a second time to strengthen his ties with other members of the nobility as well as to propagate the faith. Upon the death of the Third Dalai Lama in 1588, the Chahar princes, who had been converted to the Dgelugs-pa sect and retained their Tibetan contacts, 11 found it politically expedient to have the Dalai Lama line reincarnated in the family of Altan Qan.

\section{The Fourth DaZai Lama}

The Fourth Dalai Lama, Yon-tan Rgya-mtsho, was Altan Qan's great-grandson. Born February 15, 1589 in Kokonor, he was confirmed in his selection by a large Tibetan contingent of Dge-lugs-pa monks who traveled to Mongolia and met with the Chahar Mongol princes to strike a blatantly political deal. The Fourth Dalai Lama remained in Mongolia until he was about twelve years old. During his brief reign (d. 1617), he traveled around central Tibet to gain support for the Dge-lugs-pa. However, warfare again broke out in the Dbus region in 1612 and by 1616 Gtsang forces had occupied the whole territory of Skyid-sod and large sections of Dbus in central Tibet.

The brief and rather unsuccessful reign of the Fourth Dalai Lama was especially important as a political model, because it represented the ultimate mesh of the 'Phags-pa Lama-Qubilai relationship. The Mongol representative or regent, if you will, was in the person of an individual who at the same time was the head of Tibetan and Mongol spiritual and political power. Nevertheless, the Fourth Dalai Lama never claimed temporal authority over Mongolia, even though as a member of the Altan Qan family he could theoretically do so.

We already noted the gap between reality and theory during imperial times. Then theory held that the Tibetan 'Phags-pa Lama was the spiritual leader of the empire, but in practice the Mongols never shared any power, not even spiritual power. During the reign of the Fourth Dalai Lama, theory presupposed Mongol predominance in the new alliance. But there was no empire left and Mongol disunity on the steppe precluded any temporal power for the Fourth Dalai Lama in Mongolia. Furthermore, in Tibet the Dge-lugs-pa sect and its Mongol patrons did not have the power to ensure the Fourth Dalai Lama's spiritual, let alone temporal, ascendancy.

The failure of the Chahars to successfully support militarily the Dge-lugspa was evidenced by the king of Gtsang, a Karma-pa supporter, attacking Lhasa and expelling the Mongols in 1605. The failure of the Tibetan-Chahar alliance was due in large measure to the strategic problems of military support from Chahar to Lhasa in the face of less than effective control of the intervening Mongolian steppe. For both Mongolia and Tibet, the fusion of their powers in the person of one ruler with temporal and spiritual authority in both nations just did not prove workable in the temporal realm, and they could see that the alliance was mutually unprofitable. Notwithstanding, because of the continued ascendancy of rival Western Mongol tribes, the Chahars, now led by Ligdan Qan, 


\begin{abstract}
To Gushi Qan:
"We hear that some have been guilty of disobedience and rebellion against the religion (of the Buddha), but you have already re-established order. We reflect that from the time when the ancient Holy Kings established government, the religion of the Buddha has endured without interruption. Now We wish to show Our great respect for the Eminent Sages among the Tibetans, so We are sending envoys with the Ilakuksan Hutuketu to all alike, regardless of the colour of their robes, whether they be red or yellow, seeking everywhere for the religion of the Buddha for the protection of the Empire. This you should know. We are sending you with this letter a complete suit of armour."29
\end{abstract}

The two letters quite obviously differ in tone. The letter and large gifts to the king of Gtsang indicate Mukden's support. 30 The Manchus indicate they are up-to-date on the military situation in Tibet. The pro-Gtsang attitude is perhaps best explained as a divisive strategem and an anti-Oirat measure. Gushi Qan and his Dzungar ally Baatur Qung Taiji rivaled the Manchus for the loyalties of the Eastern Mongols. It is natural, therefore, that the Manchus should not sanction their rivals' increasing domination over 'Tibet.

In 1639 Gushi Qan gained further temporal power in Tibet with his successful eighteen-month campaign against the king of Beri in Khams. The Fifth Dalai Lama in his autobiography writes that he sent a message to Gushi Qan to subdue Beri and then return to his own country.31 When Gushi Qan approached central Tibet in 1641, the Fifth Dalai Lama maneuvered unsuccessfully for him to return to Kokonor. Gushi Qan fought a major battle with the son of the king of Gtsang, and the victorious Mongols proceeded to take over all of Gtsang, capture its king and sew him up in leather to die. The Fifth Dalai Lama further relates that he attempted to stop the fighting through negotiation via the Panchen Lama, because he was afraid the ruler of Gtsang could perhaps defeat Gushi Qan and thus destroy the Dge-lugs-pa.32 But the Dalai Lama's chief attendant Bsod-nams Chos-'phel worked to thwart any possible negotiations and actually joined Gushi Qan's forces, providing them with food and supplies. In a final great battle in early 1642 the Gtsang capital Shigatse and the Karma-pa monastery Tashizilnon were captured together with the entire royal family of Gtsang.

Gushi Qan thereupon invited the Dalai Lama to Shigatse where, with the latter's sanction, he "ascended the throne of Tibet with dignity and grandeur" in an elaborate ceremony on April 13, 1642.33 In a hall with three thrones Gushi Qan and Bsod-nams Chos-'phel sat a little lower than the Dge-lugs-pa hierarch. Gushi Qan presented a series of offerings to the Dalai Lama, one invoking Qubilai and the 'Phags-pa Lama.

The Mongol-Tibetan relationship thus created harked back to the model of Qubilai and the 'Phags-pa Lama, the same model which had inspired Altan Qan and the Third Dalai Lama. The alternative model exemplified by the Fourth Dalai Lama was rejected. Also during this time Bsod-nams Chos-'phel was installed as regent, sde-srid, to handle civil administration, with functions similar to the Dpon-chen of Mongol imperial days. This regent was the Mongol-supported administrator for the still young Fifth Dalai Lama. It was not the custom of the Dge-lugs-pa school to divide authority between a spiritual leader or abbot and secular regent, as was the Sa-skya practice. However, Gushi Qan in 1642 created such a division of power by invoking the precedent employed by the Sa-skya. 
In 1642 not only did Gushi Qan control the Fifth Dalai Lama, but even the "Great Fifth's" chief minister Bsod-nams Chos-'phel had actual temporal authority over him. Nevertheless, the Fifth Dalai Lama's spiritual supremacy over the two others was never questioned. From the political point of view, this relationship favored the Qoshod Mongols. Gushi Qan, while in fact holding the reins of political power in Tibet, did not govern Tibet as part of his empire. This is why Tucci has correctly called Gushi Qan "une sorte de protecteur du Tibet."34 Following the example of Qubilai Qan, Gushi Qan had in effect enfeoffed the Dalai Lama and his sde-srid to rule Tibet as they pleased, so long as their actions did not conflict with Gushi's interests. Until his death in 1654, Gushi spent most of his time not in Lhasa but on the steppe north of Lake Tengri or in Kokonor, wrapped up in Mongol internal politics. It is incorrect to maintain that Gushi Qan gave Tibet to the Dalai Lama. Rather this formal act must be viewed from the traditional Mongol practice of enfeoffment which is a quid pro quo relationship subject to revocation.

This approach to the relationship between the Fifth Dalai Lama and Gushi Qan underlines the difficult position the Tibetan leader faced in 1642. The Fifth Dalai Lama's greatness lay not in the fact that he re-established a strong tie with the Mongols--because he actually had little to do with delineating the nature of this relationship and was himself controlled by his own regent--but rather in the manner in which he used the theory of his spiritual superiority to gain real political power after Gushi Qan's death.

\section{Conclusion}

This has been a study of the special relationship between Mongolia and Tibet during the seventeenth century. The nature of the relationship created in 1642 by Gushi Qan and the Fifth Dalai Lama ultimately resulted in a Dge-lugs-pa government in Tibet with temporal and spiritual authority that remained in power until the Communist Chinese conquest. This relationship can, however, only be understood by examining the two models for alliance known to both nations--the first established by Qubilai and the 'Phags-pa Lama and the second established by the Fourth Dalai Lama and the Chahars. The first model proved successful for both parties but collapsed with the waning of Mongol imperial power. This fact in itself speaks for the predominance of the Mongols in the relationship. The second model, which attempted to fuse a spiritual and temporal leader into one Mongol person--the Fourth Dalai Lama--was neither very successful nor enduring. This was because the Mongols could not sustain the military obligations of the relationship and force Tibet to accept their agents, the Dge-lugs-pa.

Altan Qan and the Third Dalai Lama had sought to revive the first model, but Altan's death brought a quick end to that attempt. When Gushi Qan and the Fifth Dalai Lama again reached back to the example of Qubilai and the 'Phags-pa Lama, they consciously were rejecting the experiment attempted via the Fourth Dalai Lama.

Throughout its history, the Mongol-Tibetan relationship was always much more profitable politically for Tibet, even though the Mongols held military superiority. In striking contrast to the fate of the Sa-skya sect is the Dge-lugs-pa school's success in acquiring temporal power in Tibet in the face of the dissolution of Mongol military might. When Mongol power ebbed during the imperial 
period, the Sa-skya in turn lost control over the Tibetan political scene. The Dge-lugs-pa sect, on the other hand, masterfully entrenched itself so well in Tibet that when a power vacuum was created, it could step in. Thus the Dgelugs-pa school, led by the Fifth Dalai Lama, used the Mongol-Tibetan connection to create a strong theocracy modeled on the precedent of the Fourth Dalai Lama but personified this time by a leader of Tibetan blood. This theocracy survived not only the breakup of the special relationship developed with the Mongols, but even withstood later political crises with the Chinese, Indians, and British. Meanwhile in Mongolia the institution of the Jebtsundamba Qutughtu grew to fill the spiritual loss incurred by the breakup of the seventeenth-century MongolTibetan alliance while still exhibiting spiritual obeisance to the Dalai Lamas.

\section{Notes}

1. In October 1950 Tibet was invaded by Chinese Communist troops and the nation subsequently was incorporated into the People's Republic of China. Mongolia has fared somewhat better. Although "Inner Mongolia" has been broken up into three provinces within the PRC, "Outer Mongolia" has maintained its independence since 1911, although securely within the Soviet Union's sphere of influence since 1921.

2. During the Yüan period there were other uprisings in Tibet against the Sa-skya and their Mongol patrons, such as the 1290 'Bri-gung uprising. This and other skirmishes were, however, easily controlled.

3. His pro-Mongol attitude was very irritating to the Tibetan nobility which in that same year (125I) had unsuccessfully revolted against the Mongols and the Sa-skya school.

4. See Paul Buell, "Some Aspects of the Origin and Development of the Religious Institutions of the Early Yüan Period," unpublished thesis, University of Washington, Seattle, 1968.

5. Helmut Hoffmann, Tibet: A Handbook (Bloomington, 1975), p. 56.

6. Zahiruddin Ahmad, Sino-Tibetan Relations in the Seventeenth Century (Rome: Istituto Italiano per il Medio ed Estremo Oriente, 1970), p. 87.

7. Op. cit., p. 88. However, Ahmad cites no sources to justify his opinion. He suggests that the Dalai Lama did not go to the Mongols on the first invitation because he feared them. Since we do not know enough about the political situation in Tibet, perhaps the Dge-lugs-pa leader was not able to travel to Mongolia safely.

8. Loc. cit., citing the Third Dalai Lama's Rnam-thar, p. 90a.

9. Op. cit., pp. 89-91.

10. Supposedly the Third Dalai Lama established a diplomatic outpost at Tongkhor, also known as Lusar, where representatives of both the Lama and Altan Qan would remain to channel intercourse. Tongkhor was about halfway between Lhasa and the outpost area of Chahar. The Fourth Dalai Lama on his trip to Tibet also stopped at this place. See Tsepon W. D. Shakabpa, Tibet, A Political History (New Haven: Yale University Press, 1973), pp. 96-97.

11. Henry H. Howorth, History of the Mongols from the 9th to the 19th Century, Part 1 (London: Longman's, Green, and Co., 1876), p. 512. He indicates that Sagang Secen spoke of Abitai Ghalsagho Taiji of the Khalkhas in 1587 paying a visit to the Dalai Lama and bringing gifts. Also mentioned is Amutai Qung Taiji of the Chahars who visited the Dalai Lama.

12. Sum-pa mkhan-po Ye-shes dpal-'byor, The Annals of Kokonor, tr. by Yang 
Ho-chin (Bloomington: Indiana University Publications, Uralic and Altaic Series, 1969), p. 32.

13. In 1615 the Fourth Dalai Lama refused the invitation from the Shentsung Emperor of Ming China. "Because of his responsibilities at the Drepung and Sera monasteries, the Dalai Lama had to decline the invitation; however, he agreed to bless the temple from his monastery in Tibet, which he did by praying with his face towards China and scattering barley grain into the wind." Shakabpa, p. 99.

14. There is a certain amount of controversy in the sources about how Ligdan Qan died. Mongolian sources indicate he died of smallpox, but Tibetan accounts usually record his death as a just one at the hands of a Dge-lugs-pa champion, Gushi Qan of the Qoshod. Perhaps Tibetan accounts reflect the bitterness the Dge-lugs-pa felt over what seems to be a sudden anti-Dge-lugs-pa attitude on the part of Ligdan. However, it must be noted that there is speculation that the anti-Buddhist accusation leveled against Ligdan during his final days may have been a Ming Chinese smear against his reputation. Perhaps this issue can be better understood if Ligdan Qan's change of religious affiliation is viewed from the standpoint of political motives, since Tsoghtu Taiji, his one remaining ally, was strongly allied with Gtsang.

15. The Annals of Kokonor, p. 34.

16. Baatur Qung Taiji was the title given to him by Gushi Qan in 1637. The Chinese name is Bogatir Kontaisha巴圈理台吉; Qaraqula was also known as Khotokhotsin 和多和親 ; see Ahmad, ibid., "Genealogical Tahle II: The Jungar," and Arthur W. Hummel, Eminent Chinese of the Ch'ing Period (1644-1912) (Washington: U.S. Government Printing Office, 1943), pp. 265-266. 17. Tibetan sources use the name Gu-shri. His Chinese name was Ku-shih Han 顧惯汗. This Gushi is a title derived from the Chinese t'ai-kuo-shih 太 師. Gushi Qan's given name was Törü Baiqu (Bariqu?) Guosi, in the Shara Tudzhi, ed. N. P. Shastina, 1957, pp. 99-100.

18. Shakabpa, p. 103, writes Urluk.

19. Ar-sa-lang in the Tibetan sources. T'ai-chi is $厶$ 吉 in Chinese. The Chinese term is a Mongolian title taiji derived from t'ai-tzu 太 $子$

20. Annals of Kokonor, p. 35.

21. Loc. cit. Yang identifies this place as the upper branch of the Yangtze River (note 86). For the Fifth Dalai Lama's account see Ahmad, pp. 114-115. 22. Loc. cit. The text of a similar story in the Fifth Dalai Lama's autobiography is given in Ahmad, p. 115.

23. The Annals and the Fifth Dalai Lama's autobiography differ on the order given by Tsoghtu Taiji. The Dalai Lama's account (Ahmad, p. 115) says: "Kill him by alluring him (into a trap)," while in the Annals of Kokonor, p. 36, it reads "Kill him by (all) means."

24. Annals of Kokonor, p. 37: "Because two mountain spurs became reddened by blood, they are now known as the great and small U-lan Hosho [ulaan qosuu, 'the red promontory']."

25. Dayan Ochir Qan in Chinese is 達颜鄂即偊汗.

26. Shakabpa, p. 104.

27. Gushi Qan received the title Bstan-'dzin Chos-kyi-rgyal-po (The Upholder of the Teaching, the King according to the Faith; Dharmarāja in Sanskrit). In the Annals of Kokonor, p. 37 there is an alternate form of the same title: Bstan-'dzin Chos-rgyal (Religious-King-Who-Maintains-the-Teachings). Gushi bestowed upon the Dalai Lama's ministers various titles. At this time Baatur 
Qung Taiji acquired this title from Gushi Qan.

28. A certain Gushi Secen Chos-rje of the Oirad tribes (sometimes mistaken for Gushi Qan--see Ahmad, p. 121 for a long discussion on this individual) was sent or he in turn sent an envoy (our sources conflict) to the Mukden court of the Ch'ung-te emperor (1636-44) in late November 1637. Problems arise because Chinese records indicate the presence of Ilaghughsan Qutughtu, who was this same Gushi Secen Chos-rje, in October 1642 (Ahmad, p. 121 quoting from the Ta Ch'ing Zi-ch'ao shih-lu 大清歴朝賽録. There may in fact have been two missions. Tibetan records cited by Li Tieh-tseng show that in 1637 three Khalkha ans suggested to the Manchu emperor that he send envoys to Gushi Qan, as temporal ruler of Tibet, inviting him to the Mukden Court. Later in 1639 these sources speak of such an invitation being sent to Gushi Qan and a second to the Dalai Lama. It is thus in 1642 that the Dalai Lama, Panchen Lama, Gushi Qan, and the king of Gtsang send their responses with tribute via Ilaghughsan Qutughtu to Mukden. See Li Tieh-tseng, Tibet Today and Yesterday (New York: Bookman Associates, 1960), p. 34. See also his notes 4-6 on pp. 234-35. The Tibetan sources Li cited may have doctored the record to make it appear that the Manchus humbled themselves to the Fifth Dalai Lama and sent an invitation first. However, the accounts of Sagang Secen and the First Panchen Lama's autobiography place the diplomatic initiative in 1640. There is still no resolution to the problem over the 1642 date in the Chinese records.

29. From T'ung-hua ch'uan-lu Ch'ung-te in W. W. Rockhill, "The Dalai Lamas of Lhasa and their relations with the Manchu emperors of China 1644-1908," T'oung Pao 11 (1910), pp. 12-13.

30. The tone of the letter to Gushi Qan and the relatively simple gift bestowed on him compared to that given the king of Gtsang appear to refute Tibetan sources which detail an elaborate welcoming reception for the Ilaghughsan Qutughtu as proof of Manchu support.

31. Shakabpa, pp. 106-107.

32. Op. cit., pp. 109-110, quoting from the Fifth Dalai Lama's autobiography.

33. Ahmad, p. 134. He indicates this is from the Annals of Kokonor, but this is not in Yang's translation, see p. 39.

34. Giuseppe Tucci, Tibetan Painted Scrolls (Rome: Libreria dello stato, 1949), vol. I, p. 70, says of Gushi Qan's successors: "Greatly inferior to him in political wisdom and personal prestige, suspicious of one another and interested, over and beyond Tibet, in the events which were beginning to take shape in Mongolia." 
THE ROLE OF INNER MONGOLIA IN THE INDEPENDENCE MOVEMENT, 1911-1914

\author{
Paul Hyer \\ Brigham Young University
}

In 1911 the Mongols declared their independence from China under the ManchuCh'ing dynasty and were thus one of the first non-Western nations in modern times to escape alien subjection. They strengthened their nation through the following decades, were admitted to the United Nations and recently celebrated their fiftieth anniversary with broad recognition in the world community. But the independence movement fell short of success for more Mongolian territory remained part of China and more people were eventually left under Chinese domination than successfully escaped.

This especially important aspect of Mongolian history has been obscured. Most historians have concentrated on the event's international aspects, emphasizing the fate of the new Mongol state as it was subordinated to Russia and China, or they have concentrated on the complex developments within Outer Mongolia, the focal point of the independence movement. The role of Inner Mongolia has been ignored almost as an irrelevancy.

The Mongols originally intended to create a new empire, a Greater Mongolia (Bügude Mongghol) under a new holy emperor, the Jebtsundamba Khutughtu who, by the way, was actually a Tibetan. The new state was to encompass the huge areas of Inner Mongolia extending from Hulun-buir (Buteha and Barga) on the Siberian border to Ordos in the southwest on the border of Chinese Turkistan.

Specialists at least are familiar with the general reasons for the failure of Inner Mongolia as a whole to become unified in an independent Mongolian state after 1911. But the story has still never been told in all its detail and complexities, nor will this narrative entirely clear up this obscured event.1

The factors working for independence are quite clear. A common language and culture, a consciousness of past empire and glory, vague desires for a broader Mongolian political association and antipathy to Chinese exploitation were integrating elements for the Mongols. These factors prompted a widespread, spontaneous, favorable response for independence from the Manchu empire or from any revolutionary Chinese regime that might replace it. But this response was not unanimous or without hesitation on the part of many important leaders, a circumstance which requires further explanation.

To begin with, there was virtually no effective cohesion between the various Inner Mongolian regions--administratively, economically or in general. While certain broad generalizations may be made regarding them as a whole, one must penetrate beyond the superficial and analyze the situation and response of each region individually to gain a true perspective. Although Mongolia was more than a decade into the twentieth century, national consciousness was weak. A small group of the elite had begun to think of the fate of their country and people but the old cohesion of the empire, limited as it had been, was Iong gone and 
the new cohesion of modern nationalism was just beginning. One was soon to hear of pan-Mongolian sentiments, but from the beginning these were but romantic notions, impossible of realization within the geopolitical context of Northeast Asia. There were no mass media, no modern transportation, nor other cohesive factors to coordinate groups in an integrated movement and offset the strong regionalism which fragmented the Mongols and which was characterized by divisive stereotypes and prejudices. 2

To understand Inner Mongolia's role in the Mongolian independence movement, one must see the great difference in the various regions collectively referred to as Inner Mongolia.3 The Hulun-buir region had a historical experience and geographical situation very much different from the Kharachin and East Tumed region (Josoto league) in the southeast near the Great Wall, and different again were the western regions of Shilin-ghol, Ulanchab and Ordos.

If an understanding of the final settlement for Inner Mongolia in the independence movement requires a region-by-region analysis, then also within each region the reaction of key leaders was an important factor. The matter was not decided by a plebiscite or a public opinion poll in each banner. Needless to say, these leaders made their decisions on the basis of their perception of such overriding factors as geography and military power, political and economic ties. Examples will be given here of a variety of responses of particular leaders to the momentous event of Mongolian separation from China. The response and motivations of certain other leaders is unclear. The Inner Mongolian hero, Togtokh taiji for example, fled to Khalkha and was valiant in the fight, but one wonders what his true, most basic motivation may have been. 4

In sorting out the complex responses of people in the various regions to the announcement of independence, first to be noted was the strong emotional support for the movement. But intellectually the response was more complex. While there was a momentary joy and excitement on the part of most people throughout Inner Mongolia, there was not a simple reaction to this momentous event. Among the leaders there was soon a general consternation and ambivalence as the various areas each received communications and official documents from Urga setting forth the reasons for Mongolia breaking its ties with Peking and calling for broad support and unity throughout Mongolia.

A tentative assessment points to the conclusion that the majority of the leadership of the ten regions of Inner Mongolia--six leagues with forty-nine banners plus four related regions (the aimaghs of Chakhar, Hulun-buir, Alashan and Echina, and the Kokonor Torghuds)--initially showed spontaneous support for independence. ${ }_{5}$ Most banners apparently sent word confirming their approval of the movement. 5 According to the scholar Sh. Sandag of Ulaanbaatar, there is evidence that thirty-five of the forty-nine banners sent communications of support for the Jebtsundamba's new government. The thirty-five Sandag lists include all banners of Shilin-ghol league (10), seven of Jerim (10), six of Juu-uda (11), five of Ulanchab (6), two of Josotu (5), and five of Yeke-juu league (7).

The real problem comes in weighing the actual substance of this support, for even a cursory examination of this list immediately points up problems. Shilinghol, for one, was certainly not united, as will be seen. Moreover, the list does not include Barga (Hulun-buir), where possibly the greatest sustained support arose, nor does it include Echina and Alashan, led by Prince Tawangburijala, which seem to have been greatly influenced by the independence movement. The 
list also omits the Torghud banners of Kokonor whose Prince Palta reportedly saved the day during the siege of Khobdo by warning Urga's forces of Chinese reinforcements being sent from Shara-sume in Sinkiang to augment their forces in the city. 6

Some banners openly favored the movement while others were more cautious and secretly sent representatives to check on the new development. Most leaders were pleased and hopeful for the move but at the same time were reserved and adopted a wait-and-see policy. Wise and farsighted leaders saw the threat of Chinese colonization of Mongolia, but they also saw the dangers inherent in an attempt to break away from their Chinese overlords. Emphasis here will focus on the two most crucial areas of Shilin-ghol and Kharachin; the first because the key military campaigns were decided here, the second because of its decisive role in the political settlements with Peking.

\section{Situation in Shilin-ghol}

The situation of Shilin-ghol league (region) in the trauma of the independence movement was one of the most critical. Of all the regions, Shilin-ghol, along with Jerim, seems to have been the most divided internally as to what course to take. It did not move decisively for independence like Barga nor was it so reluctant as the Ordos, Chakhar or Western Tumet (Kueihua). Shilin-ghol was caught in a true dilemma. It was special because, like Ulanchab, it was the most exposed of the ten subregions (leagues and aimagh), having the longest border with Outer Mongolia. Traversed by the main trade routes, Shilin-ghol was the crossroads between China and Outer Mongolia. It was also the largest region, the most nomadic in life style and, in this respect, the most similar to Outer Mongolia.

The split in Shilin-ghol is confirmed in a unique oral history account of the situation from the Kanjurwa khutughtu (Living Buddha), who lived most of his life in Shilin-ghol. 7 He reports that there was a complex situation in his region with a great many debates among the princes and banner leaders and, to some degree, among the lamas about what should be done regarding the independence and the appearance of a new government in Urga. The Kanjurwa says that there was no consensus in the banner. Some leaders strongly opposed any support to the new government in Urga while others fled north with many of their people to join the movement. It would seem that support among the common people surpassed that among the elite.

The Kanjurwa notes that after a period of chaos the Chinese were soon able to again take full control of Inner Mongolia. He says that "in those days the lamas had no objection to developing a Greater Mongolia and supporting the Jebtsundamba as Bogdo khan (holy emperor)." He continues, "I heard many stories of how the lamas felt that the new Mongolia would be a Buddhist nation, a thing they all greatly desired," particularly in view of the fact that the rising Chinese geming (radical revolutionaries) were determined to tear down their Buddhist religion and destroy the faith. 8

An example of a simple positive response for independence was the case of the two Khauchid (Hochit) banners of Shilin-ghol league. The Prince of East Khauchid gathered about half of the banner population and migrated to Outer Mongolia, followed by a large part of the population of the neighboring banner, West Khauchid. 9 
Here the break was definite and permanent and the refugees made a new life in Khalkha territory. Moving the Khauchid population en masse was traumatic but was easier than the problem facing the Barga Mongols whose case is better known but less successful. The tension was compounded in central Shilin-ghol when part of the two Khauchid banners fled north, because neighboring banners were also affected due to the lack of a clear-cut boundary separating the two easternmost Abagha and Abaghanar banners.

An important factor in the tension or trauma of the split was caused by the conservative opposition--some would say realism--of Prince Yangsanjab against independence and the new Urga regime. Yangsanjab was the hereditary ruling prince (jasagh) of the Abagha left banner, neighboring the Khauchid groups that split off. He was also head of the entire Shilin-ghol league. He was capable, influential and inclined to be more loyal to the Manchu-Ch'ing dynasty. While most other Shilin-ghol leaders were for unification with Khalkha, he was skeptical about the Greater Mongolia movement and accordingly argued for neutrality or maintaining connections with Peking. He had a rather strong mental fixation on the legitimacy or continuity of the Middle Kingdom with Inner Mongolia as part

Since Shilin-ghol was the mainline of confrontation, Yangsanjab was captured by invading Outer Mongolian forces in 1913, imprisoned in Urga but later freed. 11 Yangsanjab remained conservative throughout his life. He boycotted the important autonomous movement launched in 1933 at Batu-khalagha (Pailingmiao) by Prince Demchugdungrub, and he remained aloof from the Japanese all during their long

1913 was a critical year in Shilin-ghol and most of western Mongolia when Outer Mongolian troops invaded Inner Mongolia. This was known locally as the ukher jiliin uimeen "disturbance of the year of the cow." According to popular slogans and folklore the disturbance was for the "unification of the Mongolian people and the protection of the faith." One important leader of the invading Mongolian troops was Jalkhantsa gegen, a powerful lama and intimate friend of the famous Dilowa khutughtu. There were stories abroad in those days of great miracles performed by Jalkhantsa and other powerful lama generals of the independence movement. It is of interest that the previous incarnation of the late Kanjurwa khutughtu met this famous Jalkhantsa gegen in Shilin-ghol during one of

But the independence movement was a personal tragedy for the fourth incarnation of the Kanjurwa living Buddha for it directly caused his death. He was an influential and powerful ecclesiastical figure and rather inclined to be involved in politics. He was sympathetic to the independence movement and welcomed the troops from Outer Mongolia. However, the Jangjiya khutughtu, a famous incarnation and rival of the Kanjurwa, together with his advisors and staff were tied to Peking and exploited the situation to gain advantage in the religious competition between the two men. The disciples of the Jangjiya and his pro-Peking supporters made secret accusations to Peking that the Kanjurwa was disloyal and sympathetic to the rebels. As a consequence, when the tide turned and Chinese troops arose to force out the invading Mongol troops, the Kanjurwa was killed, his temple center at Dolonor on the border of Shilin-ghol and Chakhar was burned, and many other lamas were killed or mistreated. One of the reasons motivating the Kanjurwa's support of Urga was the fact that he had many patrons and considerable wealth including thousands of horses in Khalkha and Barga, particularly 
concentrated in San-Beise banner in Sechen-khan aimagh (province). 14

\section{The Battle for Shilin-ghol}

The battle for Inner Mongolia in the independence movement was very largely determined in the frontier area of Shilin-ghol, and it is fitting here to give the essentials of the struggle. ${ }^{15}$ The main leader was Damdinsuren of the Barga area in eastern Inner Mongolia. He was early recognized as a hero of the independence movement for his valor in the successful Khobdo campaign of 1912. Indeed, after a half century he is still viewed as one of the most outstanding political and military leaders of the entire period. He has been eulogized by his biographers as being a "true son of Hulun-buir [Barga]," who had the "most advanced ideas of his time." He was regarded as one of the best educated among the nobility of his period and wrote his own official letters in excellent Mongolian or Manchu. Those who knew him said he was close to the common people, had their respect and love and was comparatively democratic in his manner. Not least, he is praised as having "revived once more the old glory of the Mongols' superiority in military arts." 16

Daminsüren was appointed by Urga as the commander-in-chief of the great campaign into Inner Mongolia. The climax came in 1913. Comparatively well-trained and equipped Chinese troops had earlier looted much of Shilin-ghol, burning temples and generally creating havoc. By the autumn of 1913 Damdinsüren, commanding some 1,000 men including an estimated 300 from Barga and an additional 700 drawn variously from the Inner Mongolian areas of Sunid, Khauchid, Abagha, Ujumchin, and Chakhar, had cleared the Chinese troops from most of Shilin-ghol. The Chinese were making sorties from their main base at Dolon-nor into the Mongolian hinterland, and the first big battle came at Khoshmog, Chagaan-nor, a sandy steppe area northwest of Dolon-nor.

Until then the Chinese had been defeated in virtually every encounter. The important Inner Mongolian leader Babujab from the Mongoljin-Tumed banner was involved in this crucial campaign and was later to gain considerable notoriety for a major uprising which he led in 1915-16. Another important compatriot of Damdinsüren in the battle for Inner Mongolia was Magsarjab. He occupied Dolonnor for a time, destroyed the Chinese garrison at Darkhan-uul and led an attack on Chinese troops stationed at Byaruu (Chin. Ching-peng).

The last great contest between the Mongols and the Chinese came at Dolon-nor in September and October. Damdinsüren and his troops fought valiantly but were forced to withdraw after nine major battles, the last of which came at Junnaiman Temple not far from Dolon-nor. From the beginning Mongol supplies, guns and ammunition were low and Urga had found it impossible to replenish them. The end came in October 1913 when supplies were gone and heavy snow and bitter cold set in. The protracted nature of the war wore the Mongols down, and they became a heavy burden on the local population in Shilin-ghol where they were quartered. It was impossible to continue the struggle to regain or hold Inner Mongolian territory as the ammunition and supplies ran out and as the troops were unfed and suffering.

Apparently the problems of the Mongolian patriots increased when Nasanarbijikh (Na Wang) "turned traitor." According to Mongolian accounts, his defection to the Chinese induced other Mongolian troops to flee or to submit as Chinese 
propaganda took effect. Meanwhile Chinese leaders in Kalgan (Chin. Chang-chiawin over Damdinsüren with promises of rank under their influence to negotiate and new president of the Republic of China. mander remained true to the caun Inner Mongolia Damdinsür the cause. After the withdrawal from the battles in his native Barga in eastern portedy relocated some one hundred Chakhar men in

In 1914 Magsarjab campaigned against Khökhe-khota (Huhehot = Kueihua), a strategic center more distant from China's center of power, and in 1915 he was about to take this city when the Khiakhta Tripartite Treaty was signed and the cause.

\section{Situation in Chakhar}

Chakhar aimagh was shielded from much of the conflict after 1911 since it had Shilin-ghol as a buffer between itself and the forces of Urga. Nevertheless, Outer Mongolian troops struck through Ujumuchin to the important temple and trade center of Dolon-nor on the eastern border of Chakhar.

Noteworthy in Chakhar was an incident involving Jodbajab, ${ }^{17}$ a senior among the various combans (officials) in the region. He had had close contact with the Manchu court and was recognized for his support as early as 1900 when during the

Jodina invaded and occupied Peking.

he also saw the folly of else a conservative man but, like most Chakhar leaders, overshadowed by China. To support the cause of independence when Chakhar was so they were willing to leave everything would have been the kiss of death unless uals and groups in other areas did. amban over the Mingghan areas did. But there was more. Jodbajab was not only Darighangha imperial pastures on the he was also responsible for the famous golia. When this strategic area was border between Inner Mongolia and Outer Mona military campaign in 1912 or 1913 to recover by the Urga forces, Jodbajab led captured by Khalkha forces and hauled north to prison in Urga.

As in other areas, the dramatic case of Jodbajab was not typical of the general feeling among the common people. Long threatened by Chinese officials and settlers and now by radical Chinese revolutionaries, they were much more inclined to separate from China and unify with a new Greater Mongolia.

Jodbajab, whether realist or opportunist, has been greatly criticized by Mongolian nationalists. Eventually he was repatriated to Chakhar, made a general by Yüan Shih-k'ai and became head of the various amban of the eight banners and four pastures of Chakhar. He was cooperative with the Japanese when they octhe Mongolian People's Republic in War II, and was again captured by forces of

\section{Situation in UZanchab}

While our assessment is still incomplete, it appears that the initial 
spontaneous response in Ulanchab was an enthusiastic support of the movement. The league's head at the time was Prince Lhawangnorbu, ruling jasagh of Durbed banner, and his lead was followed by neighboring banners. The three Urad banners did not have distinct borders and tended to be united in sending emissaries and messages of support to the new regime in Urga. In western Inner Mongolia, one cause of Mongolian alienation was the activity of I-ku, a Manchu governorgeneral who actively promoted the Chinese colonization of Mongolian land, killed a Mongol noble who opposed him, and generally distressed the people and leaders of the Ulanchab and Yeke-juu leagues. After I-ku was removed in 1905, his successor, the governor-general 18 Suiyüan, Chang Shao-tseng, continued to seize land for Chinese settlement. $18^{1}$

As initial enthusiasm subsided, the leaders of Ulanchab realized that they had to reckon with certain confrontation with the Chinese. The main figure of concern was Governor-General Chang, stationed in Suiyüan with security forces. During the transitional period following the proclamation of independence, the Ulanchab princes drew up a document that was critical of Chang's rule of the Mongol-China border region, particularly his continuation of the land grabbing policy of I-ku who had been dismissed and even imprisoned for his exploitation of the Mongols in Ulanchab and Ordos. Finally, on orders from Yüan Shih-k'ai in Peking, Governor-General Chang called a conference of the various leaders in western Mongolia in an attempt to resolve the problems.

The meeting was a sobering occasion for the princes as it was made clear to them that Chang's strategy was a steel hand in a velvet glove. They soon learned that if they remained within the Chinese sphere, they would be rewarded by a promotion in princely rank and an annual salary (feng-lu) or financial grant. But if they chose to leave they would inevitably meet the determined military power of General Chang and the Chinese troops at his disposal. In view of the overwhelming forces against them, the main result of the conference was the "pacification" of the Mongols or rather an intimidation of their leaders, effectively neutralizing their move to independence.

\section{Settlements in Western Mongolia}

For most of western Inner Mongolia, the areas of Shilin-ghol, Ulanchab, Chakhar and Ordos, the crucial time was not 1911 when independence was declared but rather 1912-13 when the real political and military contest came between the Mongols and Chinese forces for a final settlement to determine control over the border areas. Most banners with their sparse population were not prepared to defend themselves when set upon by military forces from both Outer Mongolia and China.

The Ujumuchin banner of Shilin-ghol league may be taken as an example. It was one invasion route of Outer Mongolian forces, and the particular threat here was the proposed stationing of Chinese military forces to guard against further incursions of Khalkha troops, but also to intimidate the Mongols and neutralize continuing sentiment for a separation and alliance with a Greater Mongolia. Such an occupation by a large number of undisciplined Chinese troops would indeed have been a great plague to the area, but it was avoided through the mediation of Kharachin leaders in Peking who were able to obtain a special ordinance from President Yüan Shih-k'ai. This document confirmed that the Mongol leaders and their people were not involved in any political movement and that Chinese 
military occupation was thus unnecessary. This measure avoided certain suffering of many Ujumuchin Mongols. 19

The neighboring banner of East Khauchid (Hochit), whose ruling prince had migrated with many of his people into Outer Mongolia to join the independence movement, was left without any administration. The most pressing problem in this banner, after Shilin-ghol's failure to break away from China, was to restore order and to create a new administrative structure recognized by Peking, since the area was to remain within the sphere of Chinese power. The task fell to Sungjingwangchugh, younger brother of the jasagh who had fled. Again through the mediation of the Kharachin, Lobsangchoijur, the young prince Sungjingwangchugh was recognized by the Peking government and confirmed as the new jasagh of the

\section{The Key Role of Kharachin Banner and Prince Gungsangnorbu}

In any assessment of Inner Mongolia's response to the Mongolian independence movement, a key role is played by the Kharachin banner of Josotu league. Its leaders were among the most experienced and sophisticated. They had the longest contact with the Chinese and had good connections in Peking. These factors which made the Kharachin prominent were resented by other Mongols but were important in each crisis when the necessity arose of dealing with the Chinese. In this quarter of Mongolia the situation was particularly complex. And primary focus is best given to Gungsangnorbu, prince of Kharachin, head of the Josotu league and the most progressive prince in Inner Mongolia. He was the first to establish modern schools, visited Japan in 1903 and was generally a pioneer in the modernization of Inner Mongolia.2l

In the crisis which was mounting in the fall of 1911 with Outer Mongolia moving toward independence and with increased Chinese revolutionary activity, Gungsangnorbu was caught in a dilemma. He was concerned with Mongolia's fate, but he was naturally even more concerned for the people of his own banner and the surrounding region of southeastern Mongolia--Josotu, Juu-uda, and Jerim. Here the image of the Chinese revolutionaries was most radical, and he was decidedly opposed to any new regime in China dominated by revolutionaries.

The Wuhan mutiny on October 10, 1911, which sparked the revolution, was followed by discussions at court regarding the fate of the Manchu dynasty. The Mongol princes, mainly Ghonchoghsurung of Bintu, Palta of Torghud and Bodisu of Khorchin, Gungsangnorbu, Nayantu of Khalkha, representing the sentiment of many Mongols, strenuously opposed a Manchu abdication. Gungsangnorbu made it known that if the Manchus surrendered to the revolutionaries, he would seriously consider proclaiming the independence of eastern Inner Mongolia. When the Manchu abdication and Outer Mongolian independence became a reality, Prince Gung realized that foreign assistance was absolutely necessary for the Mongols to resist Chinese forces. There were but two possibilities, Russia or Japan.

Before seeking Japanese aid, Prince Gung, together with Prince Ghonchogsurung of Bintu banner (Khorchin league), visited with the Russian deputy minister resident in Peking and discussed the possibility of Russian assistance for Inner Mongolian unity in a Greater Mongolia. This diplomat explained that Russia was sympathetic to Inner Mongolian independence but that Russian assistance was out 
of the question--because of geopolitical factors Russian assistance would be limited to Outer Mongolia. Prince Gung immediately contacted the Japanese to gain their support. His liaison was Naniwa Kawashima, advisor to his Manchu brother-in-law, Prince Su.22

Kawashima was a special agent of the Japanese military, and through him Gungsangnorbu was successful in gaining the support of the Japanese foreign minister Yasuya Uchida and General Yasumasa Fukushima of the Japanese general staff, whose contact with the Mongols extended back at least to 1900. Prince Gung arranged to borrow 200,000 yen from Japan, secured on the development of the mineral resources of Josotu league. Following Gungsangnorbu's lead, Prince Jaghar of Baarin right banner (Juu-uda league) and Prince Ghongchoghsurung of Bintu sought similar agreements with the Japanese.23

While it is not possible to follow the day-to-day actions and decisions of Gungsangnorbu, it is clear that he had two major priorities. First, he wanted to develop a new unity integrating the banners and leagues of southeastern Mongolia (Josotu, Juu-uda, and Jerim) preliminary to some greater alliance, and second, to negotiate the support of Japan.

Immediately following the Manchu abdication on February 12, 1912 Prince Gung returned to Kharachin and convened a conference at Ulaan-khada (Ch'ih-feng) with leaders and delegates from the various banners of the three leagues of southeastern Mongolia. As a key leader and spokesman in the discussions he made it clear that he favored separation from China and unification in a Greater Mongolia. 24 Another strong leader at the conference was Yao-shan, a commoner from Keshigten banner (Juu-uda league), who also supported a move for independence.25

Fragmentary reports of the conference confirm that most of the Inner Mongolian princes were ambivalent about independence, more precisely that they were apprehensive about separation from China. If such a move were successful and all lived happily ever after there would be virtually no objection. But if a Greater Mongolia (Bügüde Mongghol) was to be a romantic dream crushed by Chinese armies all would be lost, including their official rank, personal wealth and the luxurious life most had gained from their economic contacts with the Chinese world, mainly from the lease or sale of land. They were emotionally attracted to a united Mongolia but restrained by rational considerations which were usually overriding. Their natural impulse was to pursue independence as proposed by Prince Gung. At the same time they realized that such a move was dangerous because their territories were in southern Inner Mongolia, close to the political seat of Chinese power and such military garrisons as Mukden and Cheng-te.

They favored establishing close relations with the Urga government. A unification of all Mongolia on the cultural basis of language, religion and tradition appealed to them but their national consciousness was weak. The independence movement predated the real rise of a Mongolian nationalism, and narrow, regional loyalties exhibited themselves. The concept of a unified nation state was foreign to them. The Naiman prince, among others, voiced the opinion that Prince Gung or he himself should become khan (emperor) of Mongolia and not a Tibetan monk like the Jebtsundamba Living Buddha. The Ulaan-khada conference failed to produce any definitive agreements, and action was suspended until it was clear as to what support was fortheoming from Japan.

Prince Gung was disappointed at the indecisive action of the Ulaan-khada 
conference; nevertheless he dispatched a personal emissary, Lobsangchoijur, to Outer Mongolia to establish contact with the new government.

Meanwhile Altanochir (Chin-yün-ch'ang) was sent to the Japanese base at Dairen to obtain weapons according to agreements made in January 1912. Altanochir was successful in obtaining military supplies which were transported by railroad to Cheng-chia-t' un. From here the materiel was to be further transported by oxcarts, but the operation was almost immediately attacked by Chinese forces, several men were killed and Altanochir barely escaped after a harrowing experience. 26 This was but one of a series of events that scuttled further attempts to effectively unite and arm the Josotu, Juu-uda and Jerim leagues for the crisis and to take them out of China's orbit and into a new Mongolian state.

A most serious problem was the loss of Japanese support that was crucial for the success of any movement. The Japanese were initially skeptical of Yüan Shih-k'ai and the new Republic of China but soon moved to support his plan for a new imperial dynasty. At the same time, the Japanese were also involved with Chang Tso-lin, soon to emerge as the strongman over eastern Inner Mongolia and all Manchuria. A course of action supporting either Yüan Shih-k'ai or Chang Tso-lin was inconsistent with a policy of supporting Mongolian separatist movements. Ambitious lower-level Japanese like Kawashima continued to support the Mongols, but that was not enough to tip the scales in favor of Mongolian independence.

Meanwhile, Gungsangnorbu was indirectly associated with the Tsung-she-tang, the Manchu restoration movement of his brother-in-law, Prince Su, but this was a peripheral movement which needs no detailed description here. It is reported that even Prince Gung's relations with his wife were strained because he was interested in Mongolian independence while she was more interested in a Manchu restoration.

As Yüan Shih-k'ai consolidated his control in China, it soon became unavoidable or expedient for Gungsangnorbu to respond to Yüan's summons to go to Peking. With this move and Prince Gung's immediate involvement in Peking political life although continuing his efforts for the welfare of the Mongols, the chances of the three southern leagues of eastern Mongolia to join with Khalkha and the Jebtsundamba's new government virtually evaporated. First Japanese support was lost and then the major leader of the Inner Mongolian movement.

One key was that the mainline of Japanese policy was still controlled by cautious elder statesmen and senior officers; the young officer expansionists had not yet come on the scene. Actually Japan's relations with Gungsangnorbu and the Mongols in 1911-12 foreshadowed their policy in the 1930s and 1940s. But in both situations Mongolia was subordinated to Japan's interests in China and Manchuria.

\section{Other Kharachin Leaders Involved in the Movement}

At least three prominent Kharachin Mongols were directly or indirectly involved in the Outer Mongolian movement. The first to leave Kharachin and eventually become a sojourner in Urga was Sodnam, who had broken with the banner head over problems arising from Chinese settlement of Mongolian land. He then became involved as a reporter and editor of a Mongolian newspaper in Hailar. 27 Sodnam 
was followed by Khaisan, a strong promoter of Mongolian independence, and then by Lobsangchoijur, representative of Prince Gungsangnorbu.

Khaisan's departure for Outer Mongolia was symptomatic of the problem of several Inner Mongolian leaders. He held an official position in Kharachin (meiren?) and became involved in the confrontation between the Mongols and the Chinese settlers over land problems. It must be borne in mind that as recently as 1891 there had occurred a major uprising of the Chinese Chin-tan-tao, resulting in the massacre of tens of thousands of people in Kharachin, Tumet and neighboring areas of the Josotu and Juu-uda leagues. In this conflict the influential Chinese leader Chang Lien-sheng was arrested and apparently quite brutally interrogated by Khaisan. Subsequently Chang committed suicide, and officials in the neighboring Chinese districts brought charges against the Mongols. Khaisan, fearing for his safety, fled to Urga.

While in Urga Khaisan became an active promoter of Mongolian independence and later deputy war minister under Prince Khandadorji, the real spirit behind the move for independence. Because of his excellent command of the Chinese language Khaisan, assisted by a fellow Kharachin, Sodnam, drafted many official memoranda for the new government's correspondence with the Chinese. 28

Later, as factions and problems arose in the politics of Urga, Khandadorji was poisoned and Khaisan returned to his native Kharachin and eventually took up residence in Peking. Here Yüan Shih-k'ai, new president of the Republic of China, awarded him the rank of beise, one grade higher than the rank of kung conferred upon him in Outer Mongolia. In his later years in Peking he was noted for his scholarly work, particularly a Chinese-Mongol dictionary published under the title Wu-fang yüan-yin, a rather complex dictionary that classified Chinese characters according to their sound and tone pattern.

Lobsangchoijur's Mission to Urga 29

Prince Gung's envoy to the new Urga government and the story of the mission itself are both worthy of note. Lobsangchoijur was no ordinary figure when he was welcomed in Urga by the new khan. His family had served the Kharachin banner as an administrator (jakiraghchi) for eight generations. Lobsangchoijur himself had been a lama leading a monastic life until he was in his forties, and he was the temple abbot (da-Zama) when he left the monastery to take up a secular career. He soon became well known through his negotiations with the Li-fan yüan, as an interpreter and advisor to the prominent Manchu Prince Su, and as an advisor and representative of the Thirteenth Dalai Lama of Tibet. He also became prominent in Peking in later years as an appointed member of various parliamentary assemblies.

After the Ulaan-khada conference, in order to keep open various options and courses of action, Prince Gung dispatched Lobsangchoijur as his personal representative to establish ties with the new Urga government and to officially offer his regards to the Jebtsundamda as the new chief of state. Traveling through Harbin and Siberia he arrived in Urga and immediately contacted an intimate friend and fellow bannerman, Duke Khaisan who, as already mentioned, then served as deputy war minister to the famous Khandadorji.

Lobsangchoijur was welcomed by the Jebtsundamba and other officials in a 
series of important talks and ceremonies. The most significant outcome of the meetings was a proposal by the Urga government to appoint Gungsangnorbu of Kharachin as governor of the six leagues and forty-nine banners of Inner Mongolia. Lobsangchoijur was requested to transmit the official seal of appointment and office back to Prince Gung, but he hesitated. His observations of the situation during his stay in Urga had left him with very negative impressions and a pessimistic view of the future of the new regime. He was also certainly aware of the dilemma of the Inner Mongolian banners and the unpromising outcome of the Ulaan-khada conference. Consequently, while it would be an honor for his banner head to have a prominent position in a new Greater Mongolia, he diplomatically declined the delicate responsibility. He informed the Boghdo Khan's government that he would convey their wishes to Gungsangnorbu and persuade him to come personally to accept the seal or to make some other arrangement.

While in Urga Logsangchoijur lost hope that a new day was really dawning for the Mongols after having witnessed the disunity among the leaders and the general political and economic chaos in the capital. An added factor in his particular case was his impressions of the Lamaist church. Having spent much of his life as a lama, he felt a strong commitment to Buddhism. But he was disillusioned and critical of the Boghdo Khan who was supposed to be a holy lama, but who had a wife, was too political and generally had a bad reputation for being involved in scandalous activities.

His friend Khaisan, who was much more committed to the cause of independence and the new government, was very eager for Inner Mongolia to be involved in the movement, and it was apparently on his recommendations that the new government proposed to give official seals to Prince Gungsangnorbu as head of Inner Mongolia.

Thus while Khaisan and some other Inner Mongolian patriots stayed on in Outer Mongolia, Lobsangchoijur returned to his native area. In time he became involved in the life of the community of Mongol officials and leaders in Peking while maintaining his strong concern for the welfare of the Mongols. He realized that it was necessary for those Mongols close to China to accommodate to the economic and political realities in their relationship to China. In a sense he personified the problem of most of Inner Mongolia, attracted to a new hope but eventually forced to accommodate to China.

The international context of the Mongolian independence movement was decisive, as Russia and China blocked the legitimate interests of the Mongols and as Japan failed to be supportive, but the internal military, political and economic factors noted above were also crucial though less well known.

With Inner Mongolia's failure to join a new independent Mongolia, settlement with the Chinese was negotiated mainly through Kharachin leadership. It was these Mongols who tended to be most important in many key institutions and movements concerned with Inner Mongolia in this century. While they have been criticized at times, it was this group of Mongol leaders who won many important concessions from the Chinese and continued to speak for the Mongols under overwhelming difficulties.

Kharachin Mongols became the leaders of the Mongolian-Tibetan Ministry in Peking, set up soon after the revolution of 1911 to administer affairs in China's border areas. They were also successful in organizing the Mongolian-Tibetan Academy in Peking which trained hundreds of leaders for all of Mongolia. Much 
of Kharachin lobbying was done through the Mongolian Association of Allied Princes and Nobles (Meng-ku wang-kung lien-ho-hui), a quasi-political organization in Peking. In the mid-twenties a Kharachin Mongol, Pai-yün-ti, was the head of the Inner Mongolian People's Revolutionary Party (Nei-Meng-ku kuo-mintang), and a capable representative of this group, Wu-ho-ling, led the Mongolian delegation in 1928 to negotiate a new policy or settlement for Inner Mongolia with the new Nanking government and the leaders of the ruling Kuomintang. In the 1930s and 1940s men from this same group were strong supporters of the Inner Mongolian Autonomous Movement led by the Shilin-ghol prince Demchugdungrub, and they held important positions in the Kalgan Mongolian government until its demise in 1945 .

\section{Notes}

1. This conference working paper is part of a research project on Modern Inner Mongolia being conducted by Brigham Young University's China-Mongol Border Area Studies (CMBAS) group. Much of the material is based on oral history work pursued over the last two decades in Mongolia, China and Japan.

2. See Paul Hyer, "Mongolian stereotypes and images: Some tentative observations," Mongolian Studies 5 (1979).

3. For the various Mongolian subregions see Chang Mu, Meng-ku yu-mu chi (A Record of Nomadic Mongolia), reprint Taipei, 1965 [1859], pp. 11-284.

4. G. Naraangnamjil, "A brief biography of the Determined Hero Togtokh," translated by Urgunge Onon, in Mongolian Heroes of the Twentieth Century (New York: AMS Press, 1967), pp. 43-76. Onon also notes an article on Togtokh by L. Jamsran, "He was one of the most determined men to fight against the Manchus and the Chinese," Shinjlekh Ukhaan, Am'dral [Sciences and Life], Ulaanbaatar 1970, no. 4.

5. Sh. Sandag, Mongolyn uls toriin gadaad kharittsaa, 1850-1919 (Ulaanbaatar, 1971), Vol. I, pp. 302-303.

6. Charles Bawden, The Modern History of Mongolia (New York: Praeger Publishers, 1968), p. 197.

7. Autobiography of the Kanjurwa khutughtu, recorded in Taiwan, 1972, unpublished manuscript, pp. 142-144.

8. Ibid.

9. Oral report of Shilin-ghol officials, Prince Sungchingwangchugh and others. 10. Mongolian biographical file of BYU's CMBAS; also observation of S. Jagchid during residence in Shilin-ghol during early 1940s.

11. Reported in Chinese newspapers of the period, and Mongolian biographical data file, BYU's CMBAS.

12. Paul Hyer, "Biography of Prince Demchugdungrub," unpublished manuscript. 13. Autobiography of the Kanjurwa, p. 144.

14. Ibid., pp. 144-145.

15. Most of the information summarized below is taken from Sh. Natsagdorj, "Brief biography of the Forefront Hero Damdinsüren" (Ulaanbaatar: Committee of Sciences, 1946). This very informative article has been made available in English by Urgunge Onon in his Mongolian Heroes of the Twentieth Century, pp. 77104. Onon also recommends D. Dandingav's "Those struggled for our sake" (about Forefront Hero Damdinsüren), from Utga Zokhiol, Urlag (Ulaanbaatar, May 22, 1970).

16. Damdinsüren was a representative at the important Khiakhta conference in 
1914, but he was forced to withdraw by the Chinese and Russian representatives because of his uncompromising championing of the Mongolian cause. He was disa unified, independure of the negotiations because he had dedicated himself to arrested by the Chint Mongolia. In 1920 at the age of forty-nine, he was

Chinese with Magsarjab and tortured to death.

18. See Paul Hongolian biographical data file, BYU's CMBAS,

the American West, 1974-75 "Comparative frontiers: China and the West," in Essays on

19. Unpublished biogram Young University, 1976), p. 143 ,

20. Ibid., p. 7 .

Inner Mongolian modernizatin Jagchid, "Prince Gungsangnorbu: Forerunner of 158. This is a summary of a " ZentraZasiatische Studien 12 (1978), pp. 14722. Ibid. See also Aida more detailed unpublished study.

23. For a very interesting sutomu, Kawashima Naniwa (Tokyo, 1936), p. 162. Japanese, drawing largely upon study of the relationship of Prince Gung and the Valliant, "Inner Mongolia, 1912: ies 4 (1977), p. 56-92.

24. Oral report of Sechinchoghtu (Yang Tsun-sheng) whose father attended the conference. See also Jagchid, p. 150.

25. Oral report of Yao-shan's daughter-in-law, Mrs. Rashidungdug.

27. Oral report of Altanochir; see also Robert Valliant, op. cit.

to Urga; also report of Urgumbu-ku-t'ing), Sodnam's son, who accompanied him 28. Ibid. Also Mongolian bion another of Sodnam's sons. CMBAS,

29. Ibid. 
THE INNER MONGOLIAN RESPONSE TO THE CHINESE REPUBLIC, 1911-1917*

\author{
Sechin Jagchid \\ Brigham Young University
}

After the outbreak of the Opium War, and especially during the latter half of the nineteenth century, the political environment of continental East Asia changed considerably. The power of the Western imperialists and Tsarist Russia expanded to both China and Mongolia. The Manchu defeat in that war created hardships for Chinese peasants, and the Ch'ing dynasty replaced its ban on Chinese migration into Mongolian pasture lands with a positive policy of encouraging such migration in order to fortify against the Russian threat and ease the situation inside China. In doing so, however, the Ch'ing violated the Mongolian people's right to a livelihood in their own homeland. The dynasty placed the better grazing areas under Chinese occupation while undermining the Mongolian "feudalistic" league and banner organizations through establishing Chinese-style local governments under the pretext of administering the affairs of the Chinese settlers. The ensuing resentment and growing sense of instability gave rise to anti-Manchu movements among the Mongol nobility. A Mongolian volunteer force under Prince Senggerinchin did assist the Manchus against the T'aip'ing rebellion (1850-1864), but thereafter Mongolian rebels, recorded in Chinese materials as "Mongolian bandits," became a continuous phenomenon.

Also during this period, the Ch'ing court witnessed a gradual but steady decline in the number and frequency of visits by Mongolian nobles coming to render personal homage to the Manchu emperor. This was especially marked after the Boxer Rebellion in 1900.

The Ch'ing's "self-strengthening movement" to modernize the country generally had little influence on the Mongol nobility. Yet it did serve as a stimulus to some ambitious leaders, such as Prince Gungsangnorbu of Kharachin, who sought knowledge and assistance outside Mongolia. In 1903 he visited Japan to observe the effects of the Meiji Restoration, and after his return he established his own modern schools for both boys and girls and a military academy. He also advocated changes in the Manchu administration in Mongolia, but his proposals were rejected by the court. On the contrary, court policy toward Mongolia changed for the worse, increasing Manchu-Chinese domination of decision-making as to Mongolian affairs which, of course, only fueled Mongolian ire against the Manchus. For example, even in Prince Gungsangnorbu's Kharachin Right Banner several leaders had already left for Urga where they joined the independence movement within a short time.

In 1911, the independence movement was about to be inaugurated in Outer Mongolia, while in China the revolution headed by Sun Yat-sen began to make some

*This paper is a draft of research in progress, a collaborative work of the author with Paul Hyer, Brigham Young University. Accordingly, revision and documentation is yet to be finished. 
progress. During this period, the Ch'ing court was nominally ruled by a threeyear-old emperor, $P^{\prime} u-y i$, and the Empress Dowager Lung-yü who had neither political experience nor ambition. The real power was I-k'uang, or Prince Ch'ing, but he gradually transferred power to the shrewd Chinese minister Yüan Shih-k'ai who eventually betrayed his Manchu lords and made himself the first president of the Republic of China in 1912.

The slogan of the Chinese national revolution was "expel the barbarians, restore China, build the republic, and divide the farm lands equally." Because Chinese revolutionary proclamations lumped the Mongol Yüan and the Manchu Ch'ing dynasties together, Mongols who were literate in Chinese realized that the revolution portended disaster for the Mongols as well as for the Manchus. In addition, the word "revolution," which in Chinese is ko-ming and which should have been translated into Mongolian as khubisghal, was transliterated into ghaming or geming in Mongolian. These latter terms are defined as a group of people unlawfully attempting to overthrow proper institutions, to implement an illegitimate rule, and to destroy all established values and morality, aiming especially at the destruction of the orthodox religion, Buddhism. A fear of revolutionary Chinese attacks on their lifestyle and religion generated among the Mongols fear and hatred of the so-called ghoming movement. Even during the 1930s, after the rise of the Inner Mongolian autonomous movement, the herdsmen of Inner Mongolia were still fearful of the pernicious influence of ghaming and of Chinese penetration into Inner Mongolian pastures. Many publications in the present-day Mongolian People's Republic continue to use the word ghaming or geming to represent the Chinese warlords and their followers who imposed heavy burdens on the Mongols in 1919 and 1920.

On October 10, 1911 the Chinese declared an end to the Ch'ing dynasty and a restoration of Chinese rule in the city of Wu-ch'ang. Shortly thereafter, the Eighth Jebtsundamba Khutughtu, the Living Buddha of Urga, supported by Outer Mongolian nobles and people, declared Mongolian independence. Sun Yat-sen, just returned from abroad, was elected provisional president on January 1, 1912 and on that same day in Nanking he declared the founding of the Republic of China. In the midst of these drastic changes, the empress-dowager Lung-yü appointed Yüan Shih-k'ai to negotiate peace with Sun Yat-sen and his revolutionary government. Delegates of the two sides met at Shanghai in mid-December 1911 to consider terms. The talks focused of course on the terms for abdication and treatment of the Manchu imperial household after the establishment of the republic. The delegates from the South demanded that Mongolia be made the equivalent of a province, but this was vetoed by the Northern delegates. After a period of discussion they finally concluded that all Manchus, Mongols, Moslems, and Tibetans should be treated as equal to the Chinese so as to protect their private property and preserve ranks among the nobility.

The independence movement in Outer Mongolia and the anti-Chinese movement in Tibet drew the attention of the newly established provisional government in Nanking to the problems created by early revolutionary declarations and persuaded it to consider some concessions. In Sun Yat-sen's declaration at his inauguration as provisional president, he proclaimed that "to unify China, Manchuria, Mongolia, Moslem lands, and Tibet into one nation and to unify the Chinese, Manchus, Mongols, Moslems, and Tibetans as one man, this should be regarded as true unification of the nation." 
In Inner Mongolia, the independence movement in Urga had great influence on the people and their leaders, especially since it had the prestigious personal support of the Eighth Jebtsundamba, who had been proclaimed the Boghoda Khan (Holy Emperor) of Mongolia. After the downfall of the Ch'ing dynasty, many Inner Mongols looked to the North. At the same time, Mongolian nobles in Peking organized the Meng-ku wang-kung Zien-ho-hui (Association of Mongolian Princes and Dukes) in an attempt to influence the Shanghai talks. Prince Nayantu, who was originally from Outer Mongolia, acted as spokesman for the twenty-four Banners (eight Manchu banners, eight Mongolian banners and eight Chinese banners) by conveying their collective decision to support the Manchu emperor. This same sort of anti-republicanism characterized the attitudes of Mongolian leaders in Peking, which also influenced the talks in Shanghai. These factors eventually prompted the southern delegates to explain that the revolution was not limited to achieving narrowly defined Han-Chinese aims; rather, its purpose was to establish a commonwealth of Chinese, Manchus, Mongols, Moslems, and Tibetans. They also made it clear that the newly established Chinese government would honor the ranks and positions of the Mongolian nobility.

At the same time a group of Mongolian princes in Peking allied itself with the Manchu Prince Su (Shan-ch'i) and others in an attempt to sustain the court by force of arms. But, soon realizing that the dynasty was doomed, they turned to the Japanese for assistance.

On January 17, 1912 a conference was held in the presence of the empress dowager and Manchu and Mongolian princes and nobles, such as Prince Nayantu of Khalkha, Prince Gungsangnorbu of Kharachin, Prince Palta of Torghud, Prince Ghonchungsurung of Bintu, and Duke Bodisu of Khorchin. At that time, the Mongolian nobles all voiced their strong opposition to the abdication.

On January 28, Sun Yat-sen, as provisional president of the newly-established republic, sent a telegram to the Mongolian nobles in Peking explaining the value of the commonwealth of the five peoples, pointing out the importance of a common defense against Russia, and inviting the Mongols to send a delegate to Nanking to participate in the newly established government. On February 3 the empress dowager had the young emperor $\mathrm{P}^{\prime} u-y i$ declare his abdication which took place on the 12th. On February 5 the Senate in Nanking passed a measure, advocated by Sun Yat-sen, which (I) placed the Chinese and all other nationalities on an equal basis, (2) allowed for succession of rank and title among the princes and dukes, and (3) provided for maintenance of religious prerogatives among the Manchus, Mongols, Moslems, and Tibetans. On February 11 Sun Yat-sen as president promulgated the provisional constitution of China. Article 3 declared that "the territory of the Republic of China includes twenty-two provinces, Inner and Outer Mongolia, Tibet and Kokonor (Ch'inghai)." On February 13 Sun Yatsen resigned as provisional president, and the Senate elected Yüan Shih-k'ai as his successor. In his oath of office Yüan used the words "the five great peoples (Chinese, Manchus, Mongols, Moslems and Tibetans) all enjoy happiness and privilege."

As these events unfolded in Peking and Nanking, Prince Gungsangnorbu returned to his own banner, Kharachin, and soon gathered the leaders of the three eastern leagues of Inner Mongolia, Jerim, Juu-uda, and Josuto, at Ulaan-khada (Ch'ih-feng), where he tried to persuade them to organize an independence movement in Inner Mongolia. Before this conference, Prince Gungsangnorbu had contacted the Japanese 
and had already received a positive response from the Japanese military authorities. His own banner, however, was located too close to Peking for it to act, and after the two and one-half centuries of enforced fragmentation under the Manchu, it proved too difficult to organize the other banners into an effective alliance. Nevertheless, the prince himself still wanted to pursue his plans for independence. He sent envoys to Dairen to obtain weapons with which to equip his own troops and simultaneously dispatched his delegate, Lobsangchoijur (the author's father), to visit Urga and contact leaders there to learn whether Inner and Outer Mongolia could really be unified. Meanwhile, the group sent to Dairen for equipment was attacked at Cheng-chia-tun and the weapons were confiscated by the Chinese army. Before his delegate to Urga could return, Prince Gungsangnorbu was convinced or forced by Yüan Shih-k'ai to proceed to Peking, and his independence movement came to an end.

At about the same time the Manchu noble Shan-ch'i, or Prince Su, also escaped from Peking under Japanese protection and arrived in Dairen where he established the Tsung-she tang, the Loyalist Party, in an attempt to restore the $\mathrm{Ch}^{\prime}$ ing dynasty. The movement enjoyed support from conservative Mongols in Inner Mongolia as well as from conservative Manchus and Chinese. Among Mongol supporters was the famous "Mongolian bandit" Babujab. Although Gungsangnorbu was related by marriage to the Manchu prince he did not, at least not openly, participate in this loyalist movement. His own movement was aimed at securing independence for Inner Mongolia or for a Greater Mongolia including the Outer Mongols. Prince Ghonchungsurung of Bintu was also well known for his progressive policies, partic ularly his establishment of schools but, convinced that the cause of Inner Mongolian independence was hopeless, he left his own banner for Outer Mongolia.

This was a very frustrating and crucial period in Inner Mongolian history. Those who had tired of Manchu domination and possessed no faith in the Chinese revolutionaries all looked northward, and some of them journeyed to Urga to join the great movement. This group included the Prince of Khauchid of Shilinghol League, the anti-Chinese guerrilla leader Toghto Taiji of Jerim League, Khaisan of Kharachin and others. In addition, the entire Hulun-buir district of northeast Inner Mongolia declared independence and joined the Urga government. The nobles of Ulanchab League under the leadership of Prince Lhawangnorbu of Dörbed were also antagonized by the ghaming and showed strong interest in membership in the Urga movement.

In Peking, Yüan Shih-k'ai invested his resources shrewdly in the Mongolian situation and, of course, used Mongolian nobles as political capital. Being forced to deal with the problem of Outer Mongolian independence, he moderated his attitude toward the Inner Mongols in order to draw Outer Mongolia into his camp. It was for this reason that he regularly instructed the delegate from the Ch'ing court to discuss better future treatment of Mongolian nobles in talks with the delegate of the revolutionary government. At the same time he used proclamations by the Association of Mongolian Princes and Dukes in Peking to illustrate their trust in him and their demands for special treatment. In this way he was able to win over several Mongol leaders in Peking such as Prince Nayantu, who was originally very hostile toward Yüan and strongly opposed to abdication, Prince Amurlingghui, the grandson of Senggerinchin of the Jerim League, and other minor Mongol nobles. These shifts caused the Association of Mongolian Princes and Dukes to issue a public telegram on February 10 to 
Chinese authorities in both Nanking and Peking recommending Yüan Shih-k'ai for president. On April 4 Yüan Shih-k'ai appointed Amurlingghui director of the Office of Mongolian Affairs. On the tenth of that month the Association of the Alliance of the Five Great Peoples was established in Nanking, and three days later Yüan issued his statement accepting and promoting intermarriage of the five great peoples. On February 22 he declared that the republic would treat all citizens equally, tolerating no distinctions between the Chinese and the so-called subordinates. Accordingly, the Li-fan Yüan was formally abolished. On May 13 the Peking Government declared the creation of the Mongolian-Tibetan Affairs Bureau to function under the prime minister's office. By July 24 Yüan Shih-k'ai again declared that this bureau should report to the prime minister directly, and Yüan soon appointed Yao Hsi-kuang deputy director to oversee the affairs of the bureau. At the end of the Ch'ing dynasty Yao had been involved in Mongolian matters, but he was decidedly chauvinistic. He had sought cultivation of Mongolian lands and Chinese migration into those lands and to weaken and replace the Mongolian feudalistic-autonomous administrations by placing Mongolia directly under the Manchu-Chinese administration, similar to other provinces and prefectures. As a consequence, the Mongols hated him. Unfortunately, his doctrines have served as the blueprint for China's Mongolia policy up to the present time.

On August 10 the Peking government promulgated the Organization Law of the Parliament of the Republic of China which provided for twenty-seven Mongolian members in the senate and the same number in the lower house. Candidates could, however, qualify for membership only if they were at least twenty-five years old and could speak Chinese, which eliminated most Mongols from membership in the Chinese parliament. It was not long before Yüan Shih-k'ai realized that these provisions, coupled with his appointment of Yao Hsi-kuang, would not be welcomed by the Mongols. At the same time, though, he realized that the situation in Outer Mongolia was subversive to Chinese interests, so he ordered his foreign ministry to declare that Mongolia, Manchuria and Tibet were integral parts of China and would not be permitted to conclude treaties or borrow money from any foreign countries. This pronouncement set forth not only a defensive policy against the subversive influence of Urga but was aimed as well at preventing future potentially subversive contacts between Inner Mongolian leaders and foreign nations, such as those between Gungsangnorbu and Japan earlier. In addition, on August 19 Yüan Shih-k'ai promulgated the Regulations for the Treatment of Mongols, which recognized the governing power of the Mongolian princes over the political administration of their banners, as had been the case for over two centuries, and furthermore recognized the ranks, titles and special privileges of the Mongolian nobility.

It was about this time or earlier that Prince Gungsangnorbu of Kharachin arrived in Peking and was soon involved with the officialdom of the new republic. On August 24 Sun Yat-sen, the former provisional president of the Nanking government, arrived in Peking. The next day the party headed by Sun Yat-sen, the Tung-meng-hui, joined several other parties in a special conference and reorganized as the Kuomintang. Gungsangnorbu attended this political gathering and was elected a member of the executive board, along with Sun Yat-sen, Huang Hsing, Sung Chiao-.jen, Wang Ch'ung-hui, and several others. On November 3 Gungsangnorbu, Huang Hsing, Sung Chiao-jen, Wang Ch'ung-hui and others composed a letter to Sun Yat-sen formally electing him chairman of this newly organized party. The intimacy of the relationship between this progressive Mongolian noble and the leader 
of the Chinese revolution of course prodded the politically astute Yüan Shihk'ai into action. On September 10 Yüan appointed Gungsangnorbu director of the Mongolian-Tibetan Affairs Bureau in order to draw him away from Sun and to attract the support of the Mongolian nobility.

Prince Utai of Khorchin Right Flank Front Banner of Jerim League was a rebellious pro-Russian Mongolian leader even before the end of the Ch'ing dynasty. After the republic was established, his suspicion of any new revolution and government caused him to organize militant independence activities directed against the Chinese. He joined with Duke Rashiminjur of the Khorchin Right Flank Rear Banner to "evacuate" all the Chinese settlers who migrated into these two banners under pressure from the viceroy of Manchuria at the end of Ch'ing. They then attacked two Chinese prefectures, Tao-nan and $K^{\prime} a i-1 u$, that had been organized in the lands of the Mongolian leagues and banners. They occupied the towns and destroyed them but were soon engaged in battles with Manchu-Chinese forces from Mukden, Kirin, and Heilungchiang provinces at whose hands they were defeated. Both Utai and Rashiminjur escaped to Urga to join the Outer Mongolian government. During the same time, the two Chinese cities Hu-lun and Lupin in the Hulun-buir area were also attacked and occupied by the Mongols. Later, on October 7, demonstrating the Chinese government's intransigence in refusing to compromise with anti-republican Mongol movements, Yüan Shih-k'ai stripped Utai of all ranks and titles and appointed another noble as head of the banner. On October 28 Yüan Shih-k'ai, to placate angry Mongols, removed Yao Hsi-kuang from the deputy director's position in the Mongolian-Tibetan Bureau. He also appointed Prince Amurlingghui to proceed to the Jerim League to discuss problems in that region, persuade Mongolian leaders to support the Peking government, and in particular to encourage them to accept the new fivecolor national flag (five peoples) and obey the new republic's law forbidding Mongols to buy weapons from other countries.

Although this sort of proselytizing might have somewhat expanded the Peking government's influence among the Mongols, its general thrust was still negative. On November 17 Ghombujab, the tusalaghehi (the head official under the prince) of Jarud Left Banner of Juu-uda League, joined officials and people of the Jarud Right Banner in killing the prince and his followers who were for the republic and protective of the Chinese settlers. They occupied Chinese centers, including the city of $\mathrm{K}^{\prime} \mathrm{ai}-\mathrm{lu}$, and destroyed them, but within a short time a Chinese army arrived from Jehol and routed the Mongols who escaped to Outer Mongolia.

As a former imperial official, Yüan Shih-k'ai was thoroughly familiar with the Ch'ing court's Mongol policies and thus able to adopt and implement the same shrewd ploys. His first move was to promote in rank and title all Mongol nobles who supported him, while his second maneuver was to take full advantage of the Mongols' devotion to Buddhism. Near the end of September he invited two Mongolian high lamas, Jangjia Khutughtu and Kanjurwa Khutughtu, to come to Peking where he treated them with great respect in order to pacify recalcitrant Mongols. The problem, however, was that these two revered lamas held differing opinions. At that time Jangjia Khutughtu was still quite young and strongly influenced by his pro-Chinese disciples. On the other hand, Kanjurwa Khutughtu was possessed of strongly nationalistic feelings and was decidedly pro-Urga. Until his death, Jangjia Khutughtu acted as a loyal instrument for the Chinese in their attempts to mollify the Mongols, while Kanjurwa Khutughtu was eventually assassinated because of his pro-Outer Mongolian attitude. 
In western Inner Mongolia the leaders of Ulanchab League sided quite clearly with Urga. When on orders from the Peking government the Chinese general of Suiyulan, Chang Shao-tseng, contacted the Ulanchab leaders, they openly informed him of their belief that the new ghaming republic would destroy Mongolian traditions and their pastoral lifestyle and force them to abandon Buddhism. In response, the Peking government again promulgated the new principles for the treatment of Mongols, giving special emphasis to the government's willingness to honor the Mongols' devotion to Buddhism. Finally, by the end of 1912, princes of the Ulanchab League became convinced of the hopelessness of unifying Inner and Outer Mongolia and reluctantly turned to the Chinese. Greatly encouraged by this, Yüan Shih-k'ai promptly elevated all nobles in rank. As a special gesture designed to encourage Mongol acceptance of the new government, Yüan appointed most of the Mongolian leaders in Peking to the position of Yü-wei shih, or officers in the president's special guards. Even this was a restoration or continuation of the old Manchu policy of assigning Mongolian princes to positions of imperial service before the emperor himself. By the end of the year, Yüan Shih-k'ai had authorized special promotions for Prince Nayantu and Prince Gungsangnorbu to reward their help in establishing the republic.

On November 3, 1912 the Russo-Mongolian Treaty was signed in Urga, evidence of the fact not only that the Russians wished to reinforce the Outer Mongolian separation from China, but also that they refused to allow the Outer Mongolian government to make further moves toward merger or unification with Inner Mongolia. This treaty represented a turning point for the Inner Mongols who had been looking toward Urga with increasing anxiety. It may also have been the reason why the Ulanchab leaders abandoned their pro-Urga attitude in favor of a compromise with Peking.

1913, known in the lunar calendar as "the year of black ox," was another very crucial year for the Inner Mongols. It saw numerous skirmishes and intrusions by both Chinese forces into remote districts of Inner Mongolia and by forces from Outer Mongolia. Among Mongols that chaotic period became known as "the turmoil of the year of the ox." The area first disturbed was in Shilin-ghol League. As mentioned earlier, after independence was declared in Urga many Shilin-ghol leaders joined the movement; some even migrated to Urga in 19l1, and the influence of the independence movement persisted in the area through 1912. In 1913 the head of the league, Prince Yangsangjab of Abagha Left Banner, was arrested by Outer Mongolian forces because of his anti-Urga attitude. Yangsangjab was a conservative individual always loyal to the Manchu emperor. Even after the abdication he was convinced that the Peking regime would govern the Middle Kingdom of which Mongolia was a part, and he refused to join the Outer Mongolian government. Moreover, he was convinced that there was no hope for the unification of Inner and Outer Mongolia. He reasoned, therefore, that it would be better for Shilin-ghol to remain neutral or somewhat pro-Peking. After he was taken to Urga he was questioned and imprisoned although, of course, the Urga government later freed him. At the same time Outer Mongolian troops passed through the eastern part of the league from Ujümüchin to the Dolonor area, which was located between the Shilin-ghol League and the Chakhar aimagh. Besides being an economic center, Dolonor was also the Holy Land of Mongolian Buddhism where the Kanjurwa Khutughtu and his temple were located.

In Chakhar Jodbajab, the amban of the Mingghan and the Darighanghai pastures, the latter now known as the Süke-baator aimagh of the Mongolian People's Republic, 
shared Yangsangjab's conservative bent. When at the beginning of the independence movement Darighanghai leaned toward Urga, Jodbajab made attempts to restore it to his own administration by marching into Darighanghai, where he was captured by Outer Mongolian authorities and imprisoned in Urga. Later he, too, was set free, and in appreciation of his efforts the Peking government promoted him to lieutenant-general. The efforts of those leaders who opposed Outer Mongolian independence generally failed to alter the pro-Urga sympathies of the Inner Mongolian people who found the turmoil generated by the ghaming particularly disgusting.

In Peking the situation was somewhat different. The government had been recognized by many world powers and smaller nations because of the creation of an elected parliament. Yet several of Yüan's appointees among the Mongolian senators and representatives were not even Mongols. Yüan naturally found it beneficial to have his own people occupy parliamentary seats, but the conspiracy angered the Mongols and damaged their confidence in the new government.

Gungsangnorbu, with the support of Mongolian senators and delegates, introduced and engineered the passage of a resolution creating the Mongolian-Tibetan Academy in Peking, his great dream since his return from Japan in 1903 . He considered education for Mongols to be of primary importance and believed that the alternative would condemn them to backwardness and inferiority in the modern world. While this first step toward modernization signaled progress for Inner Mongolia, it became a personal stumbling block in his political life. Most conservative Mongol leaders considered this a substantial step toward a revolution that would damage or destroy the prerogatives of the Mongolian feudalistic and religious hierarchy, and they were openly hostile to this farsighted prince. Students at the academy were gradually introduced to democratic ideas and institutions, and their new awareness encouraged them to struggle for the elimination of Mongolian feudalistic institutions. They began to doubt whether this enlightened prince, Gungsangnorbu, would actually be willing to join them in their struggle. As a result, a wedge was driven between Mongolian liberals and conservatives with Gungsongnorbu in between, and the gap continued to grow.

The Peking government promulgated and rendered lip service to the Regulations for the Treatment of Mongols and proclaimed its intent to protect traditional Mongolian administrative institutions and power. However, it soon organized Jehol, Chakhar and Suiyüan into three special administrative districts and strengthened its administrative apparatus in those areas. The governors-general of these three areas were generally personal supporters of Yüan Shih-k'ai, and they enjoyed a free hand in bringing more Chinese settlers and in widening the reach of their Chinese administrations. Eastern Inner Mongolia fell under the shadow of the three eastern provinces of Manchuria and their non-Mongolian administrative power and suffered even more. While the governors of the three new special administrative districts were military or civilian holdovers from the Ch'ing period, the leaders of the three Manchurian provinces were newly emerged "heroes" who had been Chinese bandits whose attitudes toward the Mongols were exceedingly harsh.

Because of this harshness a well-known "Mongolian bandit," Babujab, joined the Tsung-she-tang, the Manchu loyalist party of Prince Su. He received Japanese weapons and carried out a guerrilla campaign in eastern Inner Mongolia (eastern Chakhar, northeastern Jehol, and parts of Kirin and Mukden provinces) and became 
one of the most outstanding "Mongolian bandits" during the early republican period. Along with him there appeared many so-called Mongolian bandits in Manchuria and eastern Inner Mongolia who, though known as Mongols, were generally Chinese. Babujab soon became famous throughout eastern Inner Mongolia. Those who were suspicious of the republic or the infamous ghaming and those who were angered by Chinese settlement in Inner Mongolia rebelled around him. His political goals were never clear. It is still not known whether he fought for the restoration of the Ch'ing dynasty or against the Chinese settlers, or whether he planned to join Outer Mongolia. But his supporters grew in number in the wake of his successful guerrilla engagements in the above-mentioned districts. Finally, in 1916, as he approached the walls of the city of Lin-hsi, a stronghold of the Chinese army and administration in northern Jehol, he was unexpectedly killed. After his death his followers gradually dissolved until only a group headed by his oldest son went to Outer Mongolia.

After the Year of the 0x, 1913, both Shilin-ghol and Chakhar became the site of skirmishes between Chinese and Outer Mongolian troops. However, these engagements never gave rise to any events of great political significance. In 1917 in the Mingghan pasture of Chakhar a young official, Mukdenbu, unexpectedly gathered several thousand Chakhar youths and declared independence. His group soon took action and attacked Chinese forces in Kalgan, but this movement was seemingly an isolated incident with little impact on Mongolian leaders in other areas. The group was soon overwhelmed by superior Chinese forces from Kalgan, and Mukdenbu was executed. This was the last ripple of the anti-republican military movements that had swept through Inner Mongolia.

Just prior to this event, in Peking Yüan Shih-k'ai had defeated his major political opponent, Sun Yat-sen, and had begun to establish himself as emperor of the Middle Kingdom. Before taking any action, however, he had instructed his supporters to generate public opinion favorable to him throughout Peking and North China, and the Association of the Mongolian Princes and Dukes in Peking became one of his prime touls. Through this association he encouraged many Mongol leaders to express their desire for a restoration of the monarchy with Yüan Shih-k'ai as emperor. Prince Nayantu, the leader of the group, became the movement's leading proponent. Prince Gungsangnorbu, however, was hesitant to become active in the campaign. His reluctance to participate enthusiastically may have been due either to his personal association with Sun Yat-sen or to his relatively liberal view of matters in general. Although he concealed any forceful opposition he may have felt, neither did he actively support the movement.

Aware of Yüan Shih-k'ai's ambition, the Japanese government issued an ultimatum to the Peking government known as the Twenty-One Demands. In accordance with its secret treaty with Tsarist Russia, Japan forced China to recognize eastern Inner Mongolia and southern Manchuria as special spheres of Japanese privilege. This new diplomatic ingredient won the support of many Mongols, who hoped to see greater Japanese intervention in eastern Inner Mongolia as a counterweight to Chinese power. Of course, this expectation also met with disappointment.

On December 12, 1915 Yüan Shih-k'ai proclaimed that he would accept the people's request and ascend the throne, but revolt soon erupted in southern China, and most governors and military leaders in other provinces responded to 
the revolutionary party. Yüan Shih-k'ai was forced to abdicate, and he died on June 5, 1916. During this short restoration of Chinese monarchism, Yüan again manipulated Mongolian conservatives in Peking and tried to retain their loyalty by promoting them, but his reign was so short that nothing of political significance occurred in Inner Mongolia during that period.

After the death of Yüan Shih-k'ai China entered a new era, an era of warlordism. Until 1928 China had no unified government. In North China warlords appeared one after another. The warlord in Manchuria, Chang Tso-lin, was especially anxious to cultivate more Mongolian land for Chinese settlers and his own followers, and the situation among the Mongols worsened considerably. Chinese warlords ignored Gungsangnorbu and his ideas, though he was retained as a figurehead in Peking. The outbreak of World War I in Europe and the fall of Tsarist Russia forced the Urga government to alter its policies. The agreement between China, Russia and Mongolia, signed in Khyakhta on June 7, 1915, forced the Urga government to renounce independence, but it was recognized by both China and Russia as an autonomous territory under Chinese suzerainty. These changes also forced the Inner Mongols to acknowledge Chinese domination of Mongol affairs. The implications of this new political alignment and increasing oppression by Chinese warlords were the major factors that stimulated organization of the Inner Mongolian People's Revolutionary Party, also known as the Inner Mongolian Kuomintang. It tried to forge an alliance with the Outer Mongolian People's Revolutionary Party to achieve full independence for Inner Mongolia with the assistance of the Outer Mongolian party and government, the Comintern and the Kuomintang under Sun Yat-sen's leadership. All of these organizations and events were influential to various degrees in the rise of the autonomy movement of Inner Mongolia in 1933. 


\section{THE PREHISTORY OF MONGOLIA AND THE ROOTS OF MAN IN NORTH AMERICA}

Georgeanne Lewis Reynolds

University of Connecticut

The contribution of Mongolia to the peopling of the New World is substantial. Prehistoric cultural events, reflected in cultural remains, indicate Mongolia's early, direct impact on Siberia and later, indirect impact on New World populations. Prehistoric cultural remains in Mongolia share characteristics with Siberia to the north and China to the south, yet their nature is distinctive, reflecting man's adjustment to a harsh environment and his prehistoric contact with neighboring ethnic groups.

The role of the environment cannot be underestimated in any study of Mongolian history or prehistory. I Climatic conditions, especially climatic changes, may have been responsible in part for prehistoric fluctuations ${ }^{2}$ as well as historic nomadic expansions and contractions. 3 Man's relationship with the environment was recognized by $\mathrm{N}$. C. Nelson, archeologist for the American Museum of Natural History's Central Asiatic Expedition during the 1920s. He noted that the quantity and quality of cultural remains varied with the local environmental conditions. The distribution of artifacts illustrated that "the relation between Nature and primitive man is almost as close as is the relation between any other organism and its environment." 4

The Gobi desert and surrounding areas are not the most habitable regions of the earth, yet they have been occupied more or less continuously since the Late, and probably, Middle Pleistocene. Northern Mongolia aboriginally was less inhospitable than it is today. It lay south of the ice sheets which covered Siberia. During glacial maxima, Mongolia was probably too cold and dry to support human occupation. It is therefore likely that it was first inhabited during a humid phase, corresponding to the pluvials of glacial interstadials in Siberia. 5

An early, widespread Paleolithic horizon is present in Mongolia. It consists of a group of sites containing the Levallois-Mousterian technique of stone working, a characteristic usually associated with the Middle Pleistocene. At OttsonMan't on the Chinese frontier, Okladnikov found Levallois disc-shaped cores as well as the more specialized prismatic cores and the long, wide blades struck from them. 6 On the basis of typology, he dated the site to between 50,000 and 40,000 years ago. The inhabitants may have been transitional between $H$. neanderthalensis and $H$. sapiens. Another Paleolithic location in this group, Moil'tyn-am, near Karakorum, is one of the few stratified sites in Mongolia. The combination of Levallois cores with prismatic cores was again found. Skreblos-scrapers characteristic of the Siberian Paleolithic--indicate northern influence in the assemblage, while choppers and chopping tools indicate Chinese and Southeast Asian affinities. Kuitan-Bulak, near Choibalsan, may also belong to this group. 7

In the area between Ulan Nor and the Artza Bogdo mountains Nelson found a 
quarry-workshop belonging to a later phase of the Paleolithic. The surface scatter was incredibly widespread and dense. Nelson remarked that "the artifacts lay scattered in such abundance that one could scarcely avoid stepping on them. "8 The workshop artifacts consisted of scrapers, choppers and Mousteroid points. The assemblage as a whole most closely resembles the Classic Mousterian tradition of the Middle Pleistocene. This stage also includes similar finds in the Orok Nor region. 9

It has been argued by Derevianko that the Levallois technique is probably indigenous due to its wide distribution in Mongolia.10 Others favor a western origin for this component. 11 Powers suggests that Mongolia was a contact zone between western Mousterian technologies and the North Chinese pebble tool tradition and that early stimulus from the west did occur.12 Because Mongolian Paleolithic sites include artifacts characteristic of western and southern cultures, I believe Powers' interpretation to be the most plausible.

The nature of the Mongolian Mesolithic is not fully understood. Chang notes that assemblages are microlithic in nature, 13 but Larichev sees nothing microlithic in sites of this age. 14 okladnikov observes that the raw material available in the Gobi consists in large part of small pebbles, which would lend a microlithic aspect to assemblages but would not necessarily imply a microlithic nature. 15

This controversy extends into the Neolithic. It is partly on the basis of this criterion that the nature of and the distinction between the Mesolithic and the Neolithic is blurred. One factor adding to the confusion is apparent regional specialization. 16 Assemblages in interior Mongolia are simple; along the Chinese and Siberian borders, they display a greater range of artifact types. Regional differences probably reflect adaptations to local environments and do not necessarily imply different periods of time.

Archeological remains unfortunately do not clarify the problem. This is illustrated by the principal site of this period, Shabarakh-usu in the central Gobi. Whether this stratified site is entirely Neolithic or contains a non-ceramic Mesolithic layer has yet to be determined. Nelson and Maringer saw both components, 17 but Soviet researchers, in an unpublished report, have apparently found pottery in both levels. 18 As far as I know, the problem remains unresolved.

What can definitely be said about the Mongolian Neolithic? Nelson defined it by the appearance of pottery, certain agricultural implements and arrow points, reflecting a continuing dependence on hunting in combination with incipient agriculture in northern Mongolia.19 The Neolithic is closely associated with contemporary cultures in the Soviet Far East and the Baikal area-dwelling and settlement patterns are similar, hearth arrangements are identical, and distinct similarities are present in prismatic cores and pottery. 20 Furthermore, the combination of tools made from large and small blades, as well as tools from flakes, and the persistence of the Levallois-Mousterian technique in Siberian assemblages suggest ties to the south.2I A later Neolithic stage brought red painted pottery, querns and pestles from China, ${ }^{22}$ but Siberian influence remained dominant.

How can the overall prehistoric sequence be assessed? I suggest that Mongolia was first inhabited during a humid interval during the Middle Pleistocene. Especially arid areas were occupied only intermittently. Consequent periodic dispersion of the inhabitants, as well as intrusions by outsiders, permitted cultural 
exchange. Mongolia seems to have come under the increasing influence of Siberia, and there seems to be more communication between these two areas than with China. The Mesolithic should not be defined in terms of microliths. Large blades are found as well. Of the Neolithic, I would say that the stone tool inventory remains conservative and that it developed from local Mesolithic cultures. Agriculture may be a product of stimulus diffusion from the south. Finally, I would suggest several migrations during the Late Pleistocene and Early Holocene between Siberia and Mongolia. These movements had impact on the steppe and forest tribes and this impact was eventually felt in the New World.

The initial peopling of the New World is an intricate problem, involving many points of origin, ethnic groups and time periods. Mongolian hunters did not consciously migrate north and east to populate the New World. There were several "haphazard" movements by people in response to changing environmental conditions and to the migratory patterns of the fauna they depended on. I should like to emphasize the point that there was no mass exodus from Asia to the New World at any time. It would be better stated that at various times different people from many areas of East Asia found their way to America.

Several migration routes can be distinguished. Müller-Beck dates a movement from the west at about 28,000 years ago.23 I suggest that the date of this migration, which probably originated in Central Asia, might well be pushed back due to the discovery of increasingly older sites in Siberia. I would further postulate at least two such movements. The first probably occurred anywhere from 50,000 to 30,000 years ago and brought with it the Mousterian tradition and the Levallois technique. A second movement took place, around the time Müller-Beck suggests, of people bearing Upper Paleolithic traditions--the Aurignacian, Solutrean and Gravettian among them. This is not to say that Siberia was a "technological extension of subarctic Europe during the Late Pleistocene," as Müller-Beck suggests. 24 No sites in East Asia exactly duplicate European sites, just as no sites in the New World duplicate sites in Asia.

There were at least two routes of northward migration. The first was an inland route, beginning in Southeast Asia and continuing through China and Mongolia, to Siberia. This movement of people brought with it a flake tool technology and the chopper/chopping tool tradition. Perhaps the widespread wedge-shaped core was dispersed in one of these migrations. Ramifications of this movement were felt in interior Siberia where many sites exhibit these archaic components. These sites include Mal'ta near Irkutsk, 25 Afontova Gora on the Yenesei 26 and Ust' Kanskaia in the Altai mountains. 27

A second, later movement involved northward expansion along the Pacific Coast, with some incursions inland. It consisted of people from the Amur River, Japan, Manchuria, Korea, North China and, in all likelihood, Mongolia. During glacial maxima, Japan was joined to the mainland and a coastal shelf 20 to 30 miles wide existed, facilitating movement from the mouth of the Amur and along the shores of the Sea of Okhotsk. From here these groups may have traversed the coastal ranges until they reached the Anadyr Gulf. 28 This group of people might well have introduced certain innovations such as the Araya diagonal burin from Japan, a trait found at Verkholenskaia Gora near Lake Baikal29 and also along the Pacific Rim at Ushki Lake on the Kamchatka Peninsula30 and at Anangula Island in the Aleutians. 31

The Bering Land Bridge during times of glaciation was approximately 1300 
kilometers wide32--about the same distance from the southern shores of Lake Baikal to the northern reaches of the ordos desert.23 Therefore, it was vast enough to accommodate several groups at once without their being aware of each other. It has been postulated by Laughlin that the interior of the Land Bridge was crossed by tundra-adapted big game hunters, ancestral to the Paleo-Indians and that the southern coastal route was taken by the ancestors of the Eskimos and Aleuts who had a marine-focused economy. 34 Along similar lines, Dikov postulates a movement of Paleo-Indians during the main Wisconsin glaciation which traveled down through Alaska and was responsible for such sites as the Marmes Rock Shelter in Washington State. 35 A later, post-Wisconsin movement by Paleo-Eskimos and Paleo-Aleuts brought with it the wedge-shaped core and populated early Alaskan localities, such as portions of central Alaska (the Denali Comple) and Anangula Island. This may account for some earlier dates in interior North America and later dates in the Arctic.

Mochanov distinguishes two cultural groups in Siberia during the terminal Pleistocene--the unifacial "Mal'ta-Afontova" cultural tradition and the bifacial "Diuktai" tradition.36 The people of this second tradition, who are named after the Diuktai cave site on the Aldan River, made pebble cores, Levallois cores, wedge-shaped (or Gobi) cores and skreblo--in other words, artifacts similar to those found in prehistoric Mongolia. It is suggested by Mochanov that elements of the Diuktai people migrated to North America between 18,000 and 11,000 years ago, bringing bifacial technology with them. However, independent invention in Alaska of this technological advance is quite probable. It is quite likely that elements of both the Mal'ta-Afontova and Diuktai populations founded the early core and blade technologies in Alaska. It must be pointed out in a discussion on possible dates of entry of man into the New World that the Bering Strait, only 56 miles wide between Cape Dezhnev and Cape Prince of Wales, freezes each winter so that contact between eastern Siberia and western Alaska has always been possible, even when the Land Bridge was submerged during interstadials, and during the Holocene as well.

Certain Alaskan assemblages retain a configuration of Asian traits and therefore merit discussion. The four I will discuss are all early--between 11,000 and 7,000 years ago--and are defined as core and blade technologies. 38 The first of these is the Akmak Complex of Onion Portage on the Kobuk River. 39 The assemblage in this basal stratum includes large, wide blades struck from polyhedral cores, microblades, burins, and crude bifaces used as scrapers and knives. Gallagher Flint Station, locality one, on the North Slope contains a wide variety of cores and unifacially retouched blades, but no burin or bifaces. The Denali Complex in central Alaska 40 includes the famous Campus Site near Fairbanks. 41 This group of sites is composed of wedge-shaped and polyhedral cores, microblades, burins, end scrapers, a chopping tool or scraper, a number of biface blanks and knives or spearpoints. Anangula Island in the Aleutians 42 is a completely unifacial industry. It consists of a wide variety of core types (including wedge-shaped cores), burins, and prismatic blades.

Anderson sees several similarities in the Akmak Complex to Siberian assemblages. 43 Core bifaces, blades, burins and bifacial knives are reminiscent of Mal'ta, Afontova Gora and Verkholenskaia Gora. He sees only one connection with Ushki Lake--the wedge-shaped microcores. In Alaska, Akmak has more correspondences with the Denali Complex than with Anangula. I suggest that part of the explanation involves the different environmental foci of each site. 
Gallagher Flint Station, locality one, is most like Anangula in Alaska because both lack bifaces. On the other hand, there are no burins in the assemblage, while Anangula exhibits a dependency on this artifact. Dixon has suggested that the two sites are remotely linked to a common ancestor, perhaps Tadusha in the Maritime Territory of the Soviet Union. 44

It was $N$. C. Nelson who first recognized the close correspondences between the end-scrapers, wedge-shaped cores and prismatic blades of the Campus Site to those of the pre-Neolithic Gobi. 45 Rainey also noted similarities to the Baikal area. 46 More recently, West has identified components of the Denali Comple as being related to Afontova Gora, Verkholenskaia Gora, Ushki Lake and certain localities in Japan. 47 Cores of the Kobuk Complex, which overlies the Akmak Comple of Onion Portage, resemble Campus cores, but the overall context of Akmak separates it from the Denali finds. Anangula and Gallagher Flint Station contain elements in common with the Denali Complex, but the assemblages, taken as a whole, are quite distinct from each other.

Okladnikov has identified seven Asian traits in the Anangula assemblage. 48 They are the Levallois technique, Gobi cores, pebble tools, Mousteroid points, skreblos, diagonal burins and transverse burins. The burins are most like those of the Araya Complex of Preceramic Japan. The assemblage is just as reminiscent of Japan as it is of Siberia. 49 This suggests direct influence of the Pacific Coastal migration route. Okladnikov and Laughlin examined Nelson's Gobi material and found that "the identity of artifacts is in some cases remarkable." 50 The Denali Complex and Akmak share similarities with Anangula, but close correspondences are rare. As noted above, the principal trait shared with Gallagher Flint station is that of a completely unifacial technology. Beyond this, the two sites are quite different.

Despite the significant differences apparent in these assemblages, certain components link them together and point to a common ancestor in East Asia. The presence of wedge-shaped cores and prismatic blades, both common in prehistoric Mongolia, reflect this. Differentiation has occurred due to the several routes taken by the Paleo-Eskimos and Paleo-Aleuts as they approached the Land Bridge and moved across it. Regional variation, different subsistence strategies and various ecological adaptations also explain the distinct nature of each site. 51

The exact nature and extent of influence of Mongolia on the New World is hard to put into concrete, quantifiable terms. At this point only general statements can be made. There are several cultural attributes which occur early in Mongolia, are found later in Siberia and reappear in the New World. Entire duplication of assemblages will not be found and direct correspondences of individual artifacts are rare. The basic fact that a Gobi core was fashioned in the desert-steppe about 20,000 years ago and that a Campus core was manufactured in a forested zone about 8,000 years ago is crucial in the interpretation of man's ability to adjust to new situations through time and space. Human beings evolve and adapt to different surroundings and this is reflected in their material culture.

\section{Notes}

1. Owen Lattimore, "The geographical factor in Mongol history," in Studies in Frontier History (London: Oxford University Press, 1962), p. 241.

2. Roy Chapman Andrews, "Explorations in the Gobi desert," National Geographic 
Sites Discussed in the Text

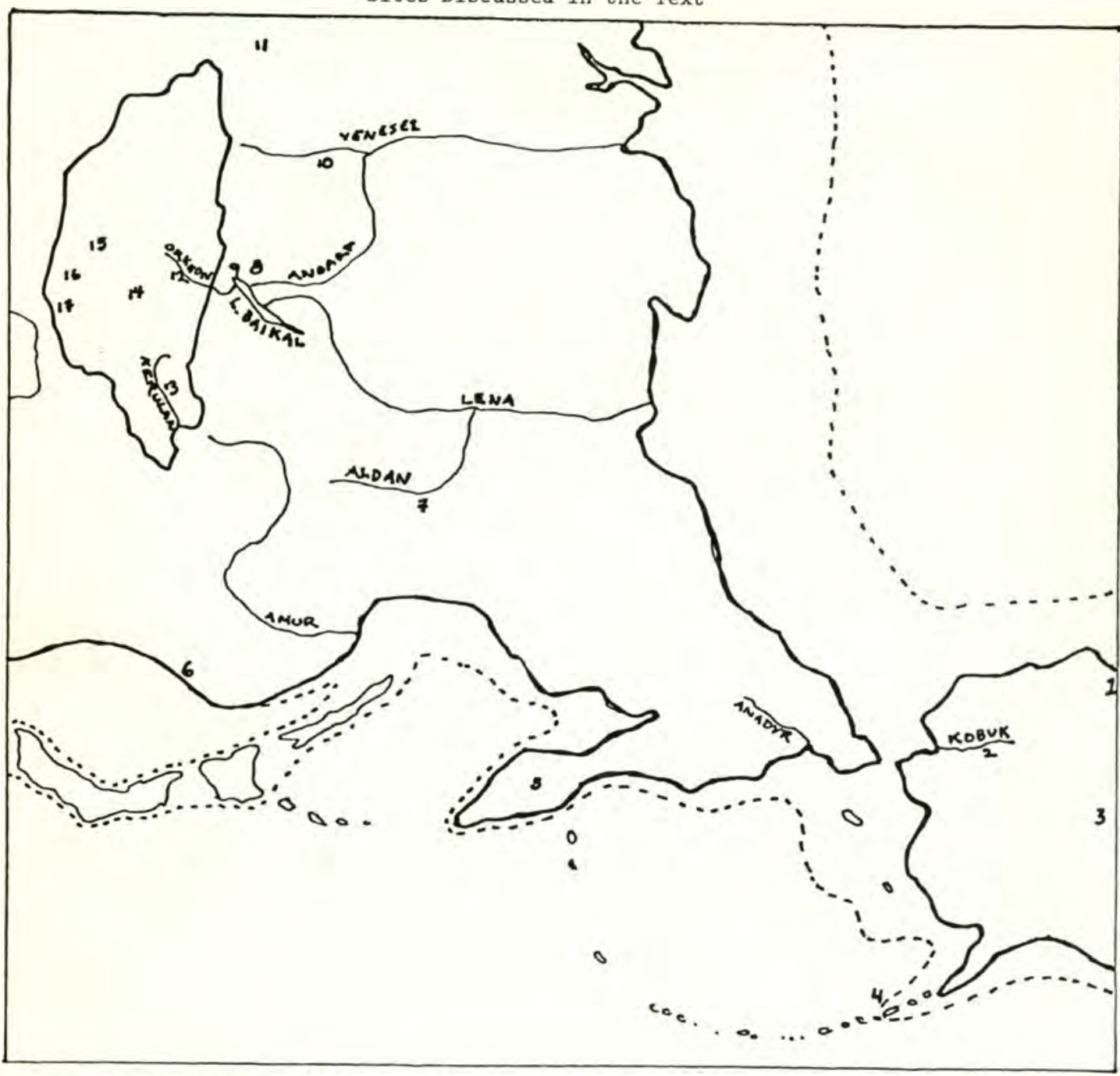

1-Gallagher Flint Station

2-Onion Portage (Akmak)

3- Campus Site

4-Anangula Island

5-Ushki Lake

6-Tadusha

7-Diuktai Cave

8-Mal'ta

9-Verkholenskaia Gora

10-Afontova Gora

11 -Ust'Kanskaia

12-Moil'tyn-am

13-Kuitan-Bulak

14-Shabarakh-usu

15-Orok Nor

16-Ulan Nor

17-0ttson-Man't

----Extent of the Bering Land Bridge during the Wisconsin glaciation 


\section{SLIDES PRESENTED}

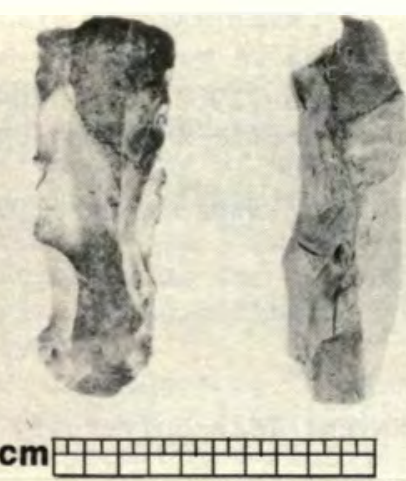

Left: Large Mongolian blade of red jasper from the general vicinity of Shabarakh-Usu. Right: Large blade of metamorphosed argellite from Anangula Island.

Length of both approximately $12 \mathrm{~cm}$.

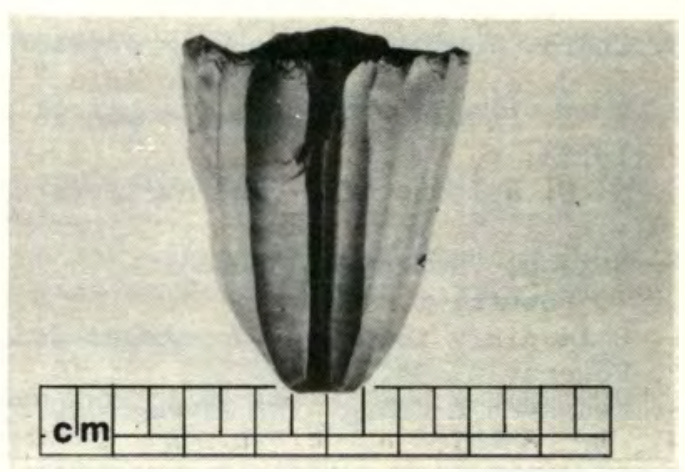

Anangula wedge-shaped core of brown chert, frontal view. Maximum height: $4.5 \mathrm{~cm}$.

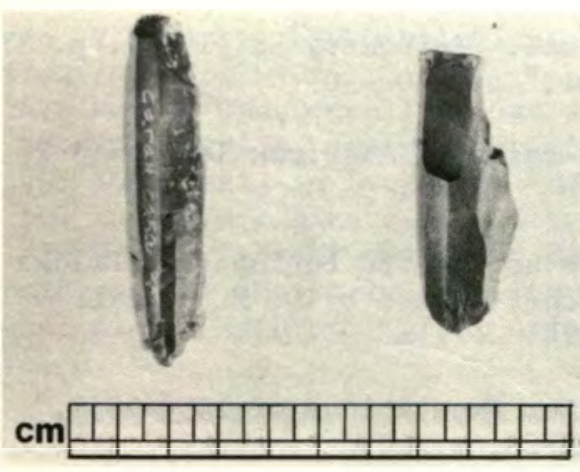

Left: "Pencil-shaped" conical core of chert from the general vicinity of Shabarakh-Usu. Maximum height: $5.5 \mathrm{~cm}$.

Right: "Pencil-shaped" conical core of chert from Sagan-Saba, Lake Baikal area.

Maximum height: $6.75 \mathrm{~cm}$.
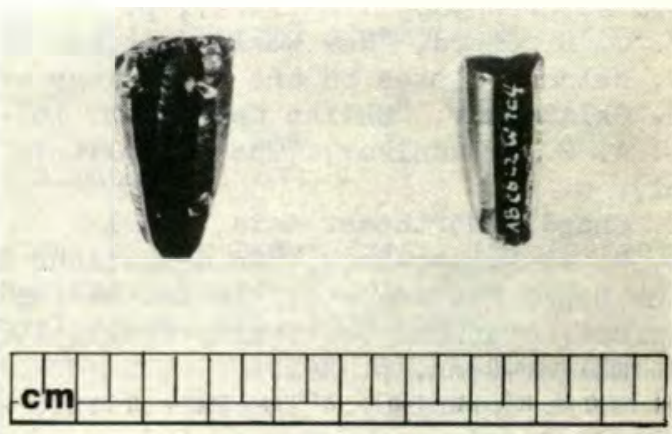

Two conical cores of obsidian from Anangula Island. Maximum heights: $3.5 \mathrm{~cm}$. and $2.75 \mathrm{~cm}$. 
Magazine 63 (1933), p. 688; C. S. Chard, Northwest Asia in Prehistory (Madison: University of Wisconsin Press, 1974), p. 15.

3. Ellsworth Huntington, Civilization and Climate (New Haven: Yale University Press, 1915), p. 391.

4. N. C. Nelson, "Notes on the archaeology of the Gobi," American Anthropologist 28 (1926), p. 305 .

5. Chard, Northeast Asia in Prehistory, p. 12.

6. In C. S. Chard, "Northeast Asia," Asian Perspectives 6 (1963), pp. 10-11.

7. W. R. Powers, "Paleolithic man in North East Asia," Arctic Anthropology $10: 2$ (1973), p. 94 .

8. N. C. Nelson, "The dune dwellers of the Gobi," Natural History 26 (1926), p. 247.

9. Nelson, "Notes," p. 308.

10. In Powers, p. 94.

11. Okladnikov in Chard, Northeast Asia, p. 14.

12. Powers, p. 94.

13. Kwang-chih Chang, The Archeology of China (New Haven: Yale University Press, 1963), pp. 66-67.

14. V. E. Larichev, "The microlithic character of Neolithic cultures in Central Asia, Trans-Baikal and Manchuria," American Antiquity 27 (1962), p. 318.

15. A. P. Okladnikov, "The Shilka Cave: Remains of an ancient culture of the Upper Amur River," in The Archaeology and Geomorphology of Northern Asia, edited by H. N. Michael (Toronto: University of Toronto Press, 1964), p. 171.

16. J. Maringer, Contribution to the Prehistory of Mongolia (Stockholm: SinoSwedish Expedition Publication no. 34, VII: Archaeology, 1950), p. 5.

17. Nelson, "Dune dwellers," p. 248; J. Maringer, "Mongolia before the Mongols," Arctic Anthropology 1:2 (1963), p. 78 .

18. C. S. Chard, "New World origins: A reappraisal, "Antiquity 33 (1959), p. 47.

19. Nelson, "Nates on the archeology of the Gobi," pp. 306-307.

20. Okladnikov, "Shilka Cave," pp. 167-168.

21. A. P. Okladnikov, "The Paleolithic of Trans-Baikal," American Antiquity 26

(1961), p. 486.

22. Chard, "Northeast Asia," p. 13.

23. H. J. Müller-Beck, "On migrations of hunters across the Bering Land Bridge

in the Upper Pleistocene," in The Bering Land Bridge, edited by D. M. Hopkins

(Stanford: Stanford University Press, 1967), p. 374.

24. Müller-Beck, p. 391.

25. M. M. Gerasimov, "The Paleolithic site Mal'ta: Excavations of 1956-1957,"

in The Archaeology and Geomorphology of Northerm Asia, p. 14.

26. J. B. Griffin, "Some prehistoric connections between Siberia and America," Science 131 (1960), p. 802.

27. S. I. Rudenko, "The Ust'Kanstkaia Paleolithic core site, Siberia," American Antiquity 27 (1961), p. 206.

28. C. S. Chard, "New World migration routes," Anthropological Papers of the University of Alaska 7:1 (1958), p. 24.

29. Chard, Northeast Asia, p. 61.

30. N. N. Dikov, "The discovery of the Paleolithic in Kamchatka and the problem of the initial occupation of America," Arctic Anthropology 5:1 (1968), p. 194.

3l. W. S. Laughlin, "Aleuts: Ecosystem, Holocene history and Siberian origin," Science 189 (1975), p. 513.

32. W. S. Laughlin, "Eskimos and Aleuts: Their origins and evolution," Science 142 (1963), p. 644. 
33. G. Bushnell and C. McBurney, "New World origins seen from the Old World," Antiquity 33 (1959), p. 100.

34. Laughlin, "Human migration and permanent occupation in the Bering Sea area," in The Bering Land Bridge, p. 421.

35. N. N. Dikov, "Ancestors of Paleo-Indians and Proto-Eskimo-Aleuts in the Paleolithic of Kamchatka," in Early Man in America from a Circum-Pacific Perspective, edited by A. L. Bryan (Calgary: Archaeological Researches International, Ltd., 1978), p. 68.

36. Yu. A. Mochanov, "The Paleolithic of Northeast Asia and the problems of the first peopling of America," in Early Man, p. 67.

37. I. Rouse, "Peopling the Americas," Quatemary Research 6 (1976), p. 604.

38. F. H. West, "The alignment of Late Paleolithic chronologies in Beringia," paper presented at the All-Union Symposium on the Correlation of Ancient Cultures of Siberia and Adjoining Territories of the Pacific Coast, Novosibirsk, October 20-22, 1975.

39. D. D. Anderson, "A Stone Age campsite at the gateway to America," Scientific American 218:6 (1968), pp. 24-33, and Akmak: An Early Archaeological Assemblage from Onion Portage, Northwest Alaska. Acta Arctica, no. 16, 1970.

40. F. H. West, "The Donnelly Ridge site and the definition of an early core and blade complex in Central Alaska," American Antiquity 32:3 (1967), pp. 360-382.

41. Nelson, "Early migration," p. 356, and "Notes on cultural relations between Asia and America," American Antiquity 4 (1937), 267-272.

42. Laughlin, "Eskimos and Aleuts," pp. 633-645, and "Aleuts," pp. 507-515.

43. Anderson, Akmak, pp. 62-69.

44. E. J. Dixon, "The Gallagher Flint Station, an Early Man site on the North Slope, Arctic Alaska," Arctic Anthropology 12:1 (1975), p. 72.

45. Nelson, "Notes on cultural relations," p. 268.

46. F. Rainey, "Archaeological investigations in Central Alaska," American Antiquity 5:4 (1940), p. 302.

47. West, "The Donnally Ridge site," pp. 375-377.

48. In Laughlin, "Aleuts," p. 513.

49. Yoshizaki, in Laughlin, "Eskimos and Aleuts," p. 634.

50. Laughlin, "Aleuts," p. 514.

51. D. C. Plaskett and E. J. Dixon, "Men out of Southeast Asia: An alternative hypothesis for the early peopling of the Americas," paper presented at the fifth annual Alaska Anthropological Association conference, Anchorage, March 17-18, 1978 , p. 8 . 


\title{
THE OYROT UNDER MANCHU RULE: \\ SOCIAL AND ADMINISTRATIVE POLICIES
}

\author{
Keith Scott \\ University of Saskatchewan
}

In this paper I propose to examine quite briefly some of the circumstances surrounding the transfer to Manchu sovereignty in the mid-eighteenth century of those areas of steppeland to the west of the Altay which had formed the pastures, or were under the control, of Züüngar or Oyrot clans. Under what kind of social and administrative arrangements did the Manchus envisage accommodating their new subjects, once the "pacification" of these areas had been completed?

It must appear that, by choosing such a topic, I have laid myself open to the serious charge which every responsible historian seeks to avoid: that of dealing with the irrelevant, of indulging in vain speculation about "what might have happened if . . ." For it is well known that after the 1755-59 pacification campaign only a small remnant of the Oyrot peoples survived, and though this remnant became subject to the Manchu emperor, its allegiance was a mere formality, a minor item of business for the attention of the hastily constituted military administration of the Western Regions.

My intention, however, is not to speculate about a non-existent Oyrot settlement and its equally hypothetical consequences, but to suggest that there is some profit to be gained from going further back in time and retracing the historical byway that leads to this particular dead end. The conventional wisdom has it that the annexation of züungar lands by the Manchus was the realization of a long-range strategy, an objective kept constantly inview, despite periodic changes in short-term tactics, throughout the first century of Manchu rule from Peking, and consistently pursued from the time of the war against Galdan in 1690-96. This position, implicit in much Western historiography, has found no less favor with Soviet historians who, in discussing the 1755-59 campaigns, use such phrases as "the fulfillment of their [sc. the Manchus'] expansionist plans," and with contemporary Chinese apologists who see the campaigns merely in terms of the "suppression of rebellion" and the "restoration of national unity."2 My own reading of early eighteenth-century Chinese materials has impressed me rather with the indecision attendant upon so much Manchu policymaking in this area, and has persuaded me that at no time--not even when the campaigns referred to had already gotten under way--was their eventual outcome intended or foreseen. I have elsewhere propounded this view on the basis of an examination of the debate at the Manchu court, conducted throughout the reign of the Ch'ien-lung emperor, on economic policies and military attitudes toward the Züüngar. 3 Perhaps some further light might be shed if a brief attempt were made to trace the evolution of Manchu attitudes towards Züüngar society in the pre-conquest period. Hence the present inquiry, an inquiry that must be inconclusive but is not, I would hope, entirely futile.

The Ch'ien-lung (Tengeriyn tetegsen) reign period began in 1736 , the new 
emperor having succeeded to the throne late in the preceding year. At this time the interest of the Peking government in Züüngar affairs was centered upon the negotiations aimed, at least from the Manchu standpoint, at achieving a military disengagement and some form of peace settlement along the Altay frontier between Züüngar and Khalkha lands. The negotiation process had already been initiated in 1734 with the dispatch of a Manchu mission to Ili, residence of the Choros khan Galdantseren whose envoys in turn reached Peking early in 1736. ${ }^{4}$ Certain elements emerge from imperial edicts and official reports issued during the course of negotiations that shed an instructive light on the Manchus' understanding of Züüngar social dynamics, and on their perception of actual and possible future Manchu-Züüngar relations. To start with, there was apparently no disposition to regard the tribes known to them at that time under the collective designation Züüngar as anything other than a unified people under the leadership of Galdantseren; no distant memory remained, for example, of the discrepancy acidly noted by Nurhachi in 1619 between Ligdan's claim to hegemony over forty tümen and the polycentric reality of post-Yuan society. 5 Instead, the Choros khan is repeatedly enjoined to act as the benevolent patriarch of all the people (sc. the Oyrot) and to conclude the peace which would serve their long-term interests better than war. 6

The general approach adopted by the Manchus in their direct dealings with the Züüngar during the negotiations of $1736-40$ is well represented by such paternalistic tenders of advice. On more than one occasion in the course of his correspondence with Galdantseren, the Ch'ien-lung emperor emphasized the common interests shared by the Züungar and the Manchus rather than the issues that currently divided them. His expressed willingness to treat them on the same basis as the Khalkha7 or the people of China 8 may be interpreted, if one so chooses, as an invitation to move into a closer formal relationship. On the other hand, the model which the Manchus favored as the basis for a settlement was the treaty concluded with the Russians at Kyakhta in 1727 rather than the Doloonnuur convention of 1691 which made the Khalkha princes vassals of the imperial throne. I submit that the Manchus chose the Kyakhta model for three reasons. First, its emphasis on frontier delineation accorded best with the immediate geopolitical concern, that of keeping the Khalkha and the Züungar physically apart.9 Second, the Manchus harbored the illusion that one man, Galdantseren, spoke (like the Russian tsar) for all his people, and that it would be pointless to conclude individual agreements, as at Doloonnuur, with all who could be identified as tribal leaders and clan heads. Third and perhaps most importantly, the Manchus thought that the Züüngar were profoundly unwilling at this time to make the requisite sacrifice of autonomy and that they could not be pressured into making such a sacrifice, even had the Manchus wished to do so.

In actuality the 1740 agreement does not stand comparison with Kyakhta. Even after its conclusion, it remained apparent that the Züüngar had little interest in, or appreciation of, the concept of a precisely delineated border line, 10 and the most that could be expected was that unilateral observance by the Khalkha of the line theoretically determined through the negotiating process might by itself contribute to a lessening of tensions in the frontier zone. 11 The distinction between Khalkha and Züüngar is emphasized more than once in Manchu government statements after 1740. Officials are chided for confusing the Mongols in allegiance to the Manchu throne, who are to be referred to as 
Meng-ku, with the Züüngar who are $i$ ("barbarians") and thus outside the emperor's
dispensation.12

The first sign that this attitude was about to undergo some modification may be detected in an edict of 1743 in which Galdantseren is described as wai-fan rather than $i .13$ This change in terminology does not seem to me too significant in itself. I am not convinced that the Ch'ing regarded all those whom they called wai-fan as being in at least a nominally feudatory relationship with the imperial throne, as Fairbank and others have suggested. 14 The term seems, on occasion, to be used in a much looser geographical sense.

Later in the same decade, however, a Züüngar envoy was received at court and addressed in terms which would not have been inappropriately directed towards the representative of a vassal prince. The emperor declared his satisfaction with the tone and content of the letter sent by Tseveendorzh Namzhil, Galdantseren's successor. He commended the new khan for his efforts to keep the peace among his subjects, though by now he must already have felt considerable uncertainty concerning the extent of the latter's authority, both titular and actual, over the Oyrot tümen 15 Manchu and Khalkha officials had increasingly to deal with refugees--one of them a defector from the very mission that brought Tseveendorzh Namzhil's letter--16 refugees whose reports furnished a detailed picture of rivalries and dissensions within the Züüngar steppe. We may reasonably infer that voices were now beginning to be raised in Peking in favor of bringing every identifiable oyrot group into vassalage, although I have no evidence from this date explicitly supporting such an inference. But some indirect indications may be found in the official reaction to Züüngar moves towards renewing their links with Tibet.

Tseveendorzh Namzhil wisely decided to allay Manchu fears by involving the imperial government in his plans and by presenting his interest in Tibetan affairs as arising from purely religious motives. This indeed had been the burden of the letter just mentioned which so pleased the emperor. Since a constant flow of Züüngar subjects to and from Tibet could not be permitted for security reasons, an alternative offer was made to Tseveendorzh Namzhil; young men might be selected and sent to Peking for three or four years to be trained as lamas, presumably at the Yung-ho kung. 17 The khan did not respond, and the offer was almost certainly never taken up, but the Manchu government must have been aware that the mere act of making it carried at least two implications of moment. First, the Manchus now accepted, and would be recognized as accepting, some responsibility for the internal evolution of züüngar society inasmuch as they sought to impose a particular direction upon the development of its religious institutions. Secondly, the extended presence of the young trainees in the capital would bring to an irreversible end the previous isolation of the Züungar from the Sino-Manchu cultural milieu, and would in all probability lead to the creation of an influential body of opinion within the oyrot community advocating formalization of the Manchus' role as protecting power.

This summary of contacts between the Manchu court and Tseveendorzh Namzhil has entailed some telescoping of events; the latter's f'irst mission to Peking arrived there early in 1746 , but the offer to undertake the training of lamas was not put forward until some four years later. Tseveendorzh Namzhil died soon afterwards in a coup engineered by his half-brother Lamdarzh, who then found himself embroiled in a struggle for supremacy with Davaazha, a distant 
cousin whose main support came from non-Choros taizh and zaysan (most notably the Khoyd Amarsanaa). This intensification of internal feuding among the Oyrot clans, while rendering the Manchu offer inoperative and irrelevant, 18 nevertheless strengthened the hands of those Manchu officials who advocated implementing a more active and constructive policy. The illusion of Züüngar unity, and the trust in one man's capacity as overall khan to enforce that unity, 19 could no longer be sustained. By early 1754, Peking had broadly accepted that some format for relations with individual Oyrot groups must now be established, and the only questions that remained to be settled concerned the precise timing and the specific modalities of the approved course of action. The idea of military intervention, either in support of Davaazha or to impose a general settlement, was still firmly rejected,20 but the recent surrender of heads of leading Dörvöd clans $^{2 l}$ appeared to offer a practical alternative. After a substantial segment of each Oyrot tümen had come over to place itself under Manchu protection, the emperor should invite the khan of that tümen to become his vassal, and any logistical support required to enable the Oyrot of the tümen in question to recover and consolidate their position in their traditional pastures should be made available.

It soon became evident that an effective settlement would, after all, involve some commitment of Manchu military forces; by June 1754 preparations were already under way for an expedition to $\mathrm{Ili}$ in the following summer.22 Yet the objectives remained the same, and it is to these that we ought in the present instance to devote our attention, rather than to the methods used to attain them. The historical concept of the four Oyrot tümen was adopted, but as the Manchus themselves recognized to a certain extent, this was a very general and illdefined concept--it still remains a fruitful source of scholarly controversy-- 23 and an unsuitable basis for a framework of feudal relationships which would be recognized by all the Oyrot peoples. Four tümen had to be selected arbitrarily from several contenders with good historical claims. Even these four differed from one another in their degrees of social cohesion, with the Choros (at least until latterly) displaying a more clearly defined feudal structure than the loosely federated Dörvöd for instance. Besides, there were the twenty-four otog which had formed part of the appanage of the Choros khans but were not of the same lineage. One assumes that the Manchus expected the four khans, chosen by themselves since none (with the possible exception of Amarsanaa) was selfevident, to play a role in the imperial system similar to that of the four Khalkha khans, but conditions in the two Mongol groups, eastern and western, were by no means analogous. By the time the Khalkha khans were accepted into vassalage, their ascendancy over their subjects had long been established through diplomacy and force of arms, and made permanent through the system of subinfeudation they themselves had created. 24

Despite these difficulties and differences of circumstances, the Manchus went ahead with designating four tïmen on the basis of their own interests and incomplete information: the Choros, chosen in recognition of their historical leadership of the Züüngar empire; the Dörvöd who had already surrendered in substantial numbers and were thought to exhibit a touching loyalty to the imperial throne--though some were already hurrying back to the northwest to take part in the struggle for land and power; 25 the Khoyd, since Amarsanaa was clearly a force to be reckoned with; and the Khoshuud, presumably because the Manchus relied on their kinsfolk in the Tibetan borderlands to help maintain the 
stability of that sensitive frontier region.

At first the pieces of this tidy scheme seemed to be falling neatly into place. Amarsanaa, the unchallenged leader of the Khoyd, gave allegiance in September 1754.26' Tseren was thought to be the most distinguished and most compliant of the Dörvöd taizh, and his colleagues Tserenubash and Tserenmönkh seemed unlikely to dispute his confirmation as khan of this tïmen. There were strong indications that Tserenmönkh, far from having ambitions in the Dörvöd political arena, was in fact casting covetous eyes upon the pastures of the Khoyd. 27 This was understandable, the Dörvöd having been most seriously afflicted by the land shortage that had latterly developed in the Züungar steppe. Banzhil, grandson by primogeniture of the renowned Lazhan Khaan who had ruled Tibet for more than a decade earlier in the century, was the natural choice for the leadership of the Khoshuud. Only the Choros khanate was left vacant, pending the removal of Davaazh who represented the old order and was, on that account, unacceptable to the Manchus. 28 In any event, upon proclamation of these new administrative arrangements in February 1755, his status became by definition that of rebel, since he had not previously come forward to tender his allegiance. 29

Throughout 1755 the Manchu government stuck doggedly to the basic concept of the four khanates; only the list of nominees changed from time to time as one taizh after another incurred their disapproval on account of actions that showed little respect for the symmetry of Peking's grand design. 30 But as more precise information was received about the diverse character of Oyrot internal relationships, the authorities grudgingly but realistically admitted certain modifications to the original plan.

The first important innovation was the creation of chuulgan (councils), theoretically to advise the khan, but in practice to provide some recognition of other interests within the tümen. As early as November 1754 the Dörvöd chuulgan had been constituted, and the appointment of Tserenubash as head of one of its two wings helped to clarify his status, previously undefined and therefore potentially threatening, in relation to Tseren. 31

By the end of the following year, the structural diversity and variety of interests within each tümen had been further recognized by the designation of the chuulgan as the central tïmen institution. The khan would not, after all, be a hereditary chieftain or the emperor's nominee, but would be elected by the members of his tümen and would serve as chuulgany darga "chairman of the council."32 A similar system had been introduced into Khalkha in 1728. There, however, the positions of khan and chuulgany darga were often kept separate, presumably as a means of encouraging a creative tension between traditional and elective authority, one that could be expected to serve Manchu interests. 33 The merging of the two positions in the Oyrot situation may, I think, be taken to reflect an appreciation of the need to weld the oyrot into fewer, more cohesive units, and to discourage any growth of the practice of subinfeudation endemic among the Khalkha. Nevertheless, since it was predicated on the survival of the Oyrot and the need to support their efforts to manage their own affairs, it is hard to accept that the long-range intentions of the government which took such a socially constructive step, even at this late stage, included the establishment of direct administrative control over Oyrot territory and (as some have suggested, arguing retrogressively from subsequent events) the virtual alimination of its occupants. 
The Manchus were also made aware of, and addressed themselves to, the question of the twenty-four otog which had formed a part of the Züüngar empire as direct dependencies of the Choros khan.34 The original assumption that these, like all other groups falling under the general rubric of "Oyrot," would be neatly absorbed into one or another of the four designated tümen was now seen to be unrealistic and, indeed, undesirable since it was a much simpler matter to preserve them as separate administrative units, and for the Manchu emperor to assume the seignorial rights. At the same time, it came to be appreciated that these rights were accompanied by certain special responsibilities, particularly with respect to the boundaries of the otog pastures. It was the enforcement of these boundaries that had formed the basis of the otog's relationship with the Choros khan, since the otog was characteristically a small, economically defined unit, its member households linked one to another by the bond of copasturage rather than kinship. Only strong, effective Choros leadership of the Züüngar empire had, while it lasted, prevented serious encroachments on the otog pastures by numerically stronger and more powerful Oyrot groups such as the Dörvöd and Khoyd. 35

Yet a third indication of the growing sophistication in the Manchus' knowledge of Oyrot affairs is seen in the elaboration of special administrative arrangements for the zhas or monastic institutions. 36 One integral and noteworthy feature of these arrangements was the decision taken in September 1755 to proceed with the appointment of a head lama, 37 even though a few years earlier, before the evident disintegration of Züungar power, the prospect of a second khutagt west of the Altay had been one which the Manchus scarcely dared to contemplate. 38

Even as the policymakers and bureaucrats in Peking were busily refining their administrative proposals, the irrelevance of these proposals to what was actually taking place on the Central Asian frontier became increasingly clear. Amarsanaa, of course, had his own ideas about the future of the region, predicated upon the elimination of every vestige of traditional Choros power. His eventual goal being a restored Züüngar empire under Khoyd leadership, he was nevertheless willing to accept the establishment of four separate khanates as an interim measure. But a fear that this arrangement might become inconveniently permanent was apparently aroused in his mind when a taizh of the Choros, Galsandorzh, came forward as a willing candidate for the vacant position of khan and was eagerly embraced by the Manchu court. This was before Peking had adopted the concept of an elective chuulgany darga, but Amarsanaa himself proposed that a chuulgan of Choros zaysan and demch (administrative officers) should be convened to elect as khan someone of the lineage of Galdantseren, an operation over which he undoubtedly felt capable of exerting some influence. At the same time, however, he put forward as an alternative plan his own desire to see a unitary Oyrot state, suggesting that the Oyrot, unlike the Khalkha, were incapable of managing their own affairs peaceably and, in particular, of defending the frontiers of the empire against external threats without strong leadership--leadership which he, of course, stood ready to provide. 39

The emperor firmly rejected Amarsanaa's propositions; the Manchus were quite satisfied to see the Khalkha system extended to the Züüngar steppe, with the sole difference, already mentioned, that the positions of khan and chuulgany darga would be merged. Partly to allay Amarsanaa's alleged anxieties, but also to keep a watchful eye on the very type of ambitious Oyrot that he himself represented, it was decided that assistant military commanders ( $f u$-chiang-chün) and 
resident liaison officers (chu-ta ta-ch'en) would be appointed by Peking to each of the tïmen. 40

The parallel with the Khalkha situation was formally and publicly enunciated in the premature "victory proclamation" of November 21, 1755.41 This official declaration is of interest, if only because it draws attention to the complete transformation which Manchu policy had progressively undergone in less than twenty years, away from the determination to differentiate at all costs between Oyrot and Khalkha which was paramcunt at the time of the negotiations with Galdantseren.

In fact, at the moment when the victory proclamation was issued, the pacification of the Northwest remained a distant dream. Amarsanaa was in open revolt, and instead of helping to create a stable framework for the new social and administrative order, what remained of the Manchu expeditionary force was desperately fighting for its own survival. After its senior commanders were ambushed and killed by partisans of Amarsanaa, 42 the Manchu authorities devoted their entire attention to the exigencies of the military situation. No new administrative proposals were forthcoming, though we need not conclude that a firm decision had yet been taken to dismantle completely the old social system. But by the spring of 1756 a note of bitterness and betrayal is already detectable in official statements on the Züüngar situation. Amarsanaa had shown gross ingratitude, of course, but it was implied that even loyal and cooperative Oyrots such as the Dörvöd taizh Tseren and Tserenubash shared some of the blame for their weakness and inability to provide effective leadership. 43

Then, in August of the same year, it becomes evident that a new policy had begun to take shape. The concept of the four tïmen had been tacitly abandoned-though this is not confirmed in official documents until a year later 44 -- and attention had shifted to the lower level angi as the effective unit of social administration, with executive authority entrusted to clerks (tüshmel) and magistrates (zargach). 45 It seemed likely, too, that Manchu garrisons would now have to be maintained in the Northwest on a regular basis. 46

A particularly interesting commentary on the entire process of policymaking during the first twenty years or so of the Ch'ien-lung emperor's reign was an edict which he issued in January 1757 in response to court criticism of the Manchu military involvement in Oyrot affairs. In it he pointed out that, though his hopes for peace and stability had unfortunately not been realized, he had taken all decisions as part of a carefully considered and relatively modest plan. He had to resettle the four tïmen in their original pastures if the Khalkha were to be left undisturbed and the burden of supporting refugees deprived of their traditional livelihood lifted from the shoulders of the imperial treasury. Though post hoc apologetics are not uncommon in the Ch'ing annals, this statement is consistent with the course of events which we have been examining and thus has an unusual ring of honesty about it. "In sum," said the emperor, "our attitude has not been one of seeking glory; it has been entirely dictated by the exigencies of the situation."47

We may fittingly terminate our inquiry at this point, for we have reached the end of the byway we set out to explore. Subsequent events are too well known to warrant repetition here, and the context in which they took place is that of warfare, geopolitics and diplomacy. At this stage no worthwhile social policies could have been devised for the Oyrot as a whole, though an edict declaring them 
to be an endangered species and imposing a closed season on hunting them might not have been inappropriate.

By way of summary, I suggest that the following stages may be identified in the development of Manchu policies concerned with Oyrot social organization.

1. Up to 1740 the only concern of the government in Peking was to disengage itself, and its Khalkha vassals, from unnecessary involvement in Züüngar affairs.

2. Between 1743 and 1750 , i.e., during the reign of the khan Tseveendorzh Namzhil, the Manchu court decided that the Züüngar khanate should be treated as if it were an outlying vassal state, though this relationship was never formalized.

3. After 1750, with the intensification of internal feuding among the Oyrot and the increasing flow of refugees, the Manchus moved towards establishing relations with individual Oyrot groups.

4. By 1754 four Oyrot tümen had been identified; these were to become vassals of the Manchu emperor in a similar fashion to the Khalkha khanates.

5. In 1755 the Khalkha model was modified to take account of features peculiar to the Oyrot situation, i.e., the diversity of status and interest within the tümen, the traditional relationship between the Choros khan and the twentyfour otog, and the semi-independent status of the monastic lands.

6. In 1756 the Manchus abandoned the tïmen system in favor of direct control over the otog and angi, and finally:

7. Sometime during the following year, all previous plans were jettisoned as the traditional Oyrot social structure broke down completely and the Oyrot themselves faced extermination. The Züüngar steppes became a military territory of the Manchu empire, and the new masters of this territory were faced with a major problem of an entirely different order from those of the preceding hundred years of Manchu-Oyrot relations. Instead of concerning themselves with trying to understand and to regulate a complex social system, they were suddenly forced to find ways of filling up huge tracts of empty pasture land from which it appeared that man, the "social animal," had altogether disappeared.

\section{Notes}

1. I.Ya. Zlatkin, Istoriya Dzhungarskogo khanstva (Moscow: Izdatel'stvo Nauka, 1964), p. 467.

2. See, for example, articles by Shih Li-tsu, Wang Hung-chün and Liu Ju-chung in Wen wu 1976, No. 12, pp. 59-74.

3. "The evolution of the forward policy in Central Asia under Ch'ien-lung," in Papers of the XIX International Congress of Chinese Studies (Bochum: OstasienInstitut der Ruhr-Universität Bochum, 1968), pp. 88-94.

4. Hsiao-t'ing tsa-chi 1.14a; Kao-tsung shih-lu (cited as K) 10.7bl-2.

5. C. R. Bawden, The Modern History of Mongolia (London: Weidenfeld and Nicolson, 1968), p. 43.

6. K $12.16 \mathrm{bl}-18 \mathrm{a} 7$.

7. K 62.16a2-18a3.

8. K 110.12a5-13b3.

9. K 120.4a.2-5b5.

10. K 121.17al-18a9, 122.10a4-12b1.

11. K $116.2 \mathrm{~b} 3-3 \mathrm{~b} 1$. 
12. K 139.18a6-18b5, 253.8b5-9al.

13. K 190.1a9-1b7.

14. John K. Fairbank, The Chinese World Order (Cambridge: Harvard University Press, 1968), p. 7.

15. K 281.13bl-14a6.

16. K 292.21b5-23b2.

17. K 356.17b5-20al.

18. Though it was repeated to Lamdarzh in 1751; K 383.16a5-19al.

19. K 445.11bl-13a5.

20. K 456.8b5-11al.

21. K 451.11a9-13a2.

22. K 464.8b9-11a6, 465.4b3-6b5.

23. See Akira Haneda, "L'Histoire des Djounghar aux 16 e et 17 e siècles, Origine des Eleutes," Ural-Altaische Jahrbücher 42 (1970), pp. 119-126.

24. B. Vladimirtsov, Le régime social des mongols: le féodalisme nomade (Paris: Librairie d'Amérique et d'Orient/Adrien-Maisonneuve, 1948), pp. 199200.

25. K 467.5b6-6a9, 12b9-13b3, 15b1-16a4.

26. K 469.6a5-6b9, 10b3-11b2.

27. K $472.5 b 4-6 a 8$.

28. K 481.2b6-3b7.

29. K 480.22a9-24a8.

30. K 485.18a8-20b9, 496.26b5-28bl.

31. K 474.7a3-7b8.

32. K 492.8bl-10a6; see also K 498.1la7-11b5.

33. Jacques Legrand, L'administration dans la domination sino-mandchoue en Mongolie Qalq-a (Paris: Institut des Hautes Études Chinoises, 1976), pp. 97-98; Bawden, p. 55.

34. See Chun-ko-erh ch'üan-pu chi-lüeh, cited in Paul Pelliot, Notes critiques d'histoire kalmouke (Paris: Librairie d'Amérique et d'Orient/Adrien-Maisonneuve, 1960), p. 12 .

35. K 480.5b7-7a8, 485.6a3-6.

36. See Pelliot, pp. 12-13 and 73-74, n. 123.

37. K 494.19b3-2la6.

38. P'ing-ting Chun-ko-erh fang-lüeh ch'ien $54.9 \mathrm{~b} 4$.

39. K 489.28b2-3lal. Courant, unusual among later commentators, was somewhat sympathetic to Amarsanaa's case. He suggested that, far from being ambitious, Amarsanaa had good reason in traditional terms to regard himself as the rightful heir to the khanate. Although the seal of office had not actually been transmitted to him, Davaazh had verbally designated him as his successor. The evidence in support of such a contention is unknown to me. See Maurice Courant, L'Asie centrale aux XVIIe et XVIIIe siècles: empire kalmouk ou empire mantchou? (Lyon: A. Rey and Paris: Librairie A. Picard et Fils, 1912), p. 104.

40. K 490.1b8-3a8. Of course this move allayed no anxieties whatsoever. As Courant vividly expresses it, "les guerriers kholt et soungar n'étaient pas disposés à se laisser domestiquer comme les Khalkha." Courant, p. 106.

41. K 499.8al-16a7.

42. K 502.37b8-39a1, 503.3a2-5a3.

43. K 510.3b8-7a2.

44. K 543.12a6-16b8.

45. See Vladimirtsov, pp. 198 and 210.

46. K 517.3a3-4a8, 570.26a3-26b4.

47. K 527.19b5-23a6 (the translation has been slightly paraphrased). 
REPORTS 


\section{ACTIVITIES AND PUBLICATIONS OF \\ THE MONGOLIA SOCIETY (1978)}

John R. Krueger

Indiana University

The Mongolia Society, founded in 1961 as a non-profit, non-political organization devoted to all aspects of Mongolia, has given much of its energy over the years to publications. Beginning with a Newsletter (vols. 1-3, 1962-4), then a Bulletin (vols. 4-12, 1965-73), the Society now issues Mongolian Studies: Journal of the Mongolia Society, a periodical containing scholarly research articles, embracing a cross-disciplinary approach to Mongolia past and present. Volume 5 for 1978 will appear presently. A series of Occasional Papers treated the Mongolian economy, literature, religion, travel and history; and the series, Special Papers, gives works originally written in Mongolian. The Society also sponsored some other publications, like a set of maps and the popular reprinting of F. D. Lessing's large Mongolian-English Dictionary.

In 1978 the society issued as Occasional Paper 9, Ramstedt's memoirs of his travels in Mongolia and Asia, Seven Joumeys Eastward, 1898-1912 (277 pages including fifty-two photographs), an adventure-filled account of his studies and research, including valuable political information about the period of Mongolian autonomy. Occasional Paper 10 is A. M. Pozdneyev's account of life in a Mongolian Buddhist (Lamaist) monastery 100 years ago, now titled Religion and Ritual in Society: Lamaist Buddhism in Late 19th-Century Mongolia (694 pp.). It treats the divine services, the ritual, the clergy, the temple furnishings, and the relation of the church to the people.

Early in 1978 the Society issued Part One of John R. Krueger's projected large Oirat-Mongolian citation dictionary (204 pages covering the first seven letters, the vowels). The additional parts, to a total of 900 pages, will be issued later. This unique work gives the entire vocabulary of the Western Mongolian literary language for the period of about 1648 to 1924, drawing on all known edited and transcribed dictionaries and texts, plus numerous unedited documents.

Special Paper 6 is devoted to L. Dindub's Brief History of Mongolia in the Autonomous Period (214 pages in Mongolian); the editor, Dr. Hangin, gives an English introduction about the work and an index of persons treated. It is a valuable primary source scarcely available even in Mongolia any more. Special Paper 7 deals with the famous Bewitched Corpse Cycle of folktales from Indian sources, Thirteen Kalmyk-Oirat Tales, with script text, keyed glossary and literary translation into English by J. R. Krueger. It serves as a convenient handbook and introduction to Oirat (West Mongolian) Studies (120 pp.).

Occasional Paper 11 will be a new English edition of Prof. Nicholas Poppe's Russian work, Heroic Epic of the Khalkha Mongols. It is translated and edited and, after a retyping, will probably appear in mid-1979 (210 pp. typescript). 
The Society hopes to issue another reprinting of Lessing's Dictionary, an important and standard reference work indispensible for English-speakers. The pressure of other duties and the cost of printing have thus far combined to delay this much-needed publication. Volume 6 of Mongolian Studies for 1979 is already organized and will go into preparation presently.

Admission to the Society is open to all persons and institutions having interest in any aspect of Mongolia; dues are $\$ 15$ annually (students $\$ 7.50$ ). The Mongolia Society, Inc.

P.0. Drawer 606

Bloomington, Indiana 47402

\section{MONGOLISTIC ACTIVITIES AT INDIANA UNIVERSITY}

The Mongolia Society is housed in facilities of Indiana University at Bloomington, though it remains a distinct and independent institution.

Since several important projects in Mongolian studies are now under way at Indiana University, I take this liberty to mention them in the thought that some readers may thus secure information about them.

The National Endowment for the Humanities is supporting a three-year project for a new major Mongolian-English dictionary, directed by Hangin and Krueger, with research staff. The project is about half-complete, and letters A-M (about 350 typed pages) are finished in draft. The total may run to about 900 pages; after revision and limited circulation the dictionary will be printed, but it will certainly be at least two full years before it is available. This is a Cyrillic-order modern dictionary with definitions and examples in English, stressing social sciences, literature, history, etc.

The same institution, NEH, is also supporting a Mongolian folklore project which will produce an annotated volume of translated Mongolian folklore in different genres (eight to ten chapters to cover epic, tales, riddles, invocations, proverbs, etc.). A supplement will give the Mongolian texts. This will be finished in 1979 and probably published at a later time.

The Mongolian Studies Humanities Curriculum is sponsored by the office of Education and will present a one-or two-volume introduction to Mongolian history, civilization and area studies suitable for college courses in Asia. The completion of this project, delayed by many factors, is soon expected, and one would hope it might also soon be published for general use.

John R. Krueger 
THE BIBLIOTHECA MONGOLICA

Henry G. Schwarz, Man-kam Leung, and Michael Underdown

\section{General Remarks and Part I: Works in English, French, and German}

The project got its start in 1975 as a result of Henry Schwarz's conclusion, arrived at after some careful thought on the matter, that the field of Mongolian Studies needed to be strengthened, certainly in the United States and perhaps elsewhere too, and that one important way of going about this was to create a comprehensive bibliography that in a single set of volumes encompasses most if not all that has been written in various languages about most aspects of Mongolia. Whereas such comprehensive bibliographies have been published for China, Japan, and Korea, nothing quite like this has ever been published for Mongolia.

The Bibliotheca Mongolica, as originally planned, will eventually consist of four parts. Part I, edited by Henry G. Schwarz, includes works written in English, French, and German. Part II, edited by Man-kam Leung of the University of Saskatchewan, includes works written in Chinese, Japanese, and Korean. Part III, edited by Mr. Michael Underdown of the University of Melbourne, contains works in Mongolian, Russian, and East European languages. Finally, Part IV, edited by Henry G. Schwarz, will contain works written in all other languages, additions and corrections to the first three parts, and a combined index.

This bibliography includes all subjects that have a bearing on that contiguous area which was inhabited by appreciable numbers of Mongols around 1800 . In contemporary terms, this area is roughly coterminous with the Mongolian People's Republic and adjoining areas in Siberia, Sinkiang, Inner Mongolia, and the northwestern provinces of China. Thus the bibliography includes studies of pre-Mongolian and non-Mongolian subjects, such as linguistic, historical, and archeological investigations of all the peoples who inhabited Mongolia before the Mongols. It also includes studies of foreigners on Mongolian soil during Mongol times, such as missionaries, traders, and armies.

In addition, the bibliography includes any subject placed exclusively outside the area just described and that has a substantial and specifically Mongol content, like studies of Mongol conquests, Mongol languages and dialects, and Mongol emigré communities. The bibliography, however, does not include studies of individuals and groups who, despite their own claims, cannot be considered Mongol, such as Timur and his successors. Nor does the bibliography include studies of any of the non-Mongol parts of the Mongol world empire that make little or no mention of the Mongols. Thus most of the considerable body of literature on Yüan China is excluded here because most of these studies are on purely Chinese matters with only scant reference to the Mongol overlords.

The Bibliotheca Mongolica includes most forms of publication with the exception of reviews, short notices, cookbooks, annual surveys in periodical publications such as Asian Perspectives, Asian Survey, and Far Eastern Economic Review, 
and most political tracts. Only some entries in handbooks, encyclopedias and conference compendia are included. Because we hope that non-Mongolists will use this bibliography, we also include works of popular literature. The bibliography includes all publications just described and published during the century ending in December 1975. Only occasionally are older works included.

Each of the several parts of the Bibliotheca Mongolica consists of five major sections on general works, culture, history, society, and science and technology, comprising a total of thirty-four chapters, each of which constitutes a particular category. The overall arrangement is similar to that used by the Library of Congress, with deviations where deemed necessary. Entries within each subdivision are, with few exceptions, arranged by date of publication. Each work is given only one entry but is cross-listed by entry number as often as deemed appropriate.

An entry consists of the usual bibliographical elements like name, title, place and date of publication as well as any additional information such as illustration, bibliography, and the like. In order to keep the bibliography within manageable limits, annotations are held to an absolute minimum. In most cases, transliteration of proper names in annotations is the same as in the works in question. Thus any proper name is likely to appear throughout the bibliography with several slightly different spellings. Whenever a title in English, French, or German is sufficiently descriptive, no annotation or translation is given.

The person index, a feature in all parts of the Bibliotheca Mongolica, deserves special mention. It includes, besides all authors, also editors, compilers, and translators. I believe that such an arrangement may well help some readers to locate a particular work more quickly. The person index differs from indexes in most other bibliographies and monographs in at least two respects. First, translators are included because, contrary to conventional academic opinion, I am certain that translations, especially good ones, are not only great aids to the scholarship of any field but can also be major intellectual accomplishments in their own right. Second, the person index does not follow the usual practice of listing only entry numbers or, worse yet, page numbers. Such practice is a disservice to the reader whom it obliges in some cases to go back and forth between the index and the main body of the book dozens of times before he finds the entry he had been looking for.

Part I: Works in English, French, and German is complete and has been published by the Center for East Asian Studies as volume 12 of its Occasional Papers (since then renamed Studies on East Asia) series. Its 355 pages contain about 3,000 entries of which more than 95 percent were personally verified by me. Each of the remaining unverified entries is marked by the notation [Not seen].

Western Washington University

Henry G. Schwarz

\section{Part II: Works in Chinese, Japanese, and Korean}

Bibliographies on Mongolia in the Chinese and Japanese languages do exist. The present task is to update these bibliographies. In the Chinese language,

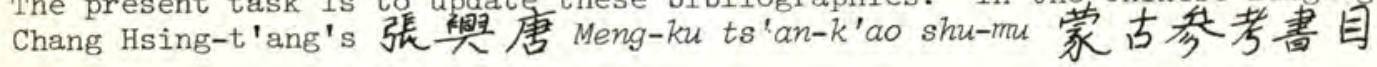


(Taipei, 1958) and Teng Yen-lin's 登行行林 Chung-kuo pien-chiang tu-chi zu 中国边疆图耤埌 (Peking, 1958) are essential sources for this project. Chang's work was compiled by consulting several existing bibliographies on the same subject. It incorporates works in Chinese, Japanese, Mongolian, and European languages. The sections on works in Chinese and Japanese languages form an adequate basis for developing a better bibliography on Mongolia. The present task facing the compiler of this bibliography is as follows: 1. To verify and update the publication data of each entry in these two bibliographies.

2. To add new materials which are not included in these two bibliographies. 3. To screen important journal articles to be incorporated into the new bibliographies.

The following gives a general description of the new materials which are going to be added to this bibliography.

The Chinese sources contain valuable primary information on Mongolia, especially on the period before the twentieth century. The recent massive reprint of Chinese local gazetteers in Taiwan has made available many sources which have hitherto been difficult to come by. These local gazetteers are a treasure house of information on local history. The projected bibliography will try to classify and distill information contained in these gazetteers.

In 1974 the National Palace Museum in Taiwan began publication of the secret palace memorials of the Ch'ing dynasty (1644-1911). These memorials were sent secretly by provincial officials to the emperor reporting on the local situation and have, therefore, never been published previously. The publication of these memorials, for the first time, is very important not only in the field of Chinese studies, but also in other areas. So far only the memorials of the K'ang-hsi (1662-1722) and the Kuang-hsü (1875-1908) reigns have been published. The memorials of the Yung-cheng reign (1723-1735) are in the process of publication. When this collection is complete, this set of materials will provide valuable insight to the Ch'ing government's policy towards Mongolia.

The publication of the diplomatic archives of the Chinese Foreign Ministry dealing with the Sino-Russian relationship between 1917 and 1921 by the Institute of Modern History, Academia Sinica in Taiwan throws much light on the complexity of diplomatic relations between China, Russia and Mongolia during this period in question.

In mainland China, the most significant development is probably in the field of linguistics. Three important dictionaries have been published: Han-Meng tz'u-tien 汉蒙榈典 (Chinese-Mongolian Dictionary) (Nei-Meng-ku jen-min chu-pan-she内蒙古民出版社 Huhehot呼和浩特, 1964); Meng-Han tz'u-tien 蒙 汉词典 (Mongolian-Chinese Dictionary) (Nei-Meng-ku chiao-yü chu-pan-she 内蒙古教育出版社 Huhehot, 1975); Meng-Han $t z^{\prime} u$ tien 蒙 汉词典 (Mongolian-Chinese Dictionary) (Nei-Meng-ku jen-min chu-panshe内蒙古人民出版社, Huhehot, 1976) all establishing lexical standardization for translation between the two languages.

On the other hand, the publication of the punctuated edition of the Iwentyfour Dynastic Histories is undoubtedly one of the most important academic achievements by mainland Chinese scholars. Each work in this series has been subject to rigorous textual criticism before publication, and modern Chinese punctuation marks are supplied throughout the text. This series, therefore, 
greatly facilitates research on Chinese history and makes the reading of geographical and personal names in these dynastic histories more intelligible, especially when these names are of foreign origins.

The two most important Japanese bibliographies on Mongolia are:

1. Yamane Yukio 山根幸夫, Gendaishi kenkyu bunken mokuroku元代史研究文献

目銶(A Classified Bibliography of Articles and Books concerning the Yuan

Perlod in Japanese and Chinese), Tokyo, 1971. This book covers works pub-

lished between 1900 and 1970 .

2. Japan Association of Mongolian Studies, Mongoru kenkyu bunken mokuroku $千$

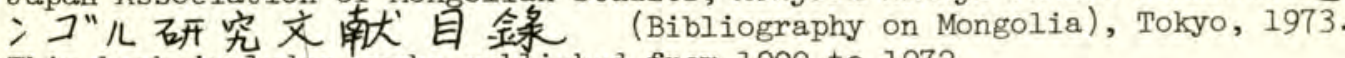

This book includes works published from 1900 to 1972.

Both of these bibliographies are useful for this project. Generally speaking, Japanese works are excellent as secondary sources. Before 1945, because of Japan's political and military ambitions in Continental Asia, Japanese scholars produced many works of lasting value in this field. The intelligence report of the Japanese army and cultural expeditions sponsored by various organizations in Japan provide a rich reservoir of information for the period after 1911.

The Chinese part is expected to be complete in 1979, and the Japanese part in 1980 .

University of Saskatchewan

Man-kam Leung

\section{Part III: Works in Mongolian, Russian, and East European Languages*}

My work as editor of Part III of the Bibliotheca Mongolica is based on my very comprehensive working bibliography and on my cataloging and bibliographic experience. However, I am basically a historian, and there are areas which it is proposed to cover in the Bibliotheca Mongolica with which I am not very familiar. I refer especially to the fields of art and architecture, music, dance, and theater, numismatics, archeology, manners and customs, education, law, economy, and science and technology. It is obviously possible for me to review all previous bibliographic sources to extract the relevant references. It is as equally apparent that outside assistance would greatly facilitate this task, but none has materialized to date.

I have encountered several objections to the project among fellow Mongolists. The main objection to the project is due to the fact that it is seen as being superfluous and a duplication of perfectly good, existing bibliographies, such as Bibliografiya rabot po Mongolii, D. Serzhmyadag, BNMAU-d 1973-1975 ond khevlegdsen mongolin nomin bürtgel (and its predecessors). The Mongolian authorities are obviously working in the direction of a "national bibliography."

The project has now reached a stage where it is too late to turn back. My own bibliography is almost complete in all fields other than those listed above up to 1975. The task now remaining is to collect entries in the missing fields and to plug any gaps. I still need to organize my files into a form suitable for typing or otherwise reproducing. This is no mean task as I have no

*Mr. Underdown had to return to Melbourne a few days before the conference, and his report was read in his absence by Professor Schwarz. 
secretarial or financial assistance to undertake this work.

I am reluctant to put a completion date on Part III, not only because I do not know whether any assistance will be forthcoming following this conference or any further appeals the general editor might make, but also because my work on the project must necessarily be performed alongside my normal duties. However, assuming that I can devote the same amount of time to this project as hitherto and that the level of assistance remains nil, I would anticipate having my listings completed by mid-1979.

It is obviously desirable to have the Bibliotheca Mongolica published as soon as possible, so please send me those lists, etc. 
Frank B. Bessac

Robert I. Binnick

Paul D. Buell

Alicia J. Campi

C. R. Chesmore, Jr.

Woon-sek Cho

Larry V. Clark

David M. Farquhar

Donald W. George

Paul V. Hyer

Sechin Jagchid

Frances H. Johnson

Edward H. Kaplan

Takuo Kidokoro

Linda Kimball
Department of Anthropology

University of Montana

Missoula, MT 54801

Department of Linguistics

University of California

Berkeley, CA 94720

(University of Toronto)

9357-56th Avenue South

Seattle, WA 98188

1411 N. Rolfe Street, 非6

Arlington, VA 22209

(Indiana University)

Department of Anthropology

Western Washington University

Bellingham, WA 98225

Center for East Asian Studies

Western Washington University

Uralic and Altaic Department

Indiana University

Bloomington, IN 47401

Department of History

University of California

Los Angeles, CA 90024

Center for East Asian Studies Western Washington University

Department of History

Brigham Young University

Provo, UT 84602

Department of History

Brigham Young University

8020 Roosevelt Way, N.E.

Seattle, WA 98115

Center for East Asian Studies Western Washington University

Embassy of Japan

Washington, DC

Center for East Asian Studies Western Washington University 
Hisao Kimura

John R. Krueger

Man-kam Leung

Ronald Loftus

Ulrich Mammitzsch

Nicholas Poppe

Georgeanne Lewis Reynolds

Richard E. Salzer

Henry G. Schwarz

Keith Scott

Toru Takemoto

James Talbot

Colin E. Tweddell

Mary Frances Weidlich

Winston Wu
Asia University

Sakai, Musashino-shi

Tokyo 180, Japan

Uralic and Altaic Department Indiana University

Far Eastern Studies

University of Saskatchewan

Saskatoon, Canada S7N OWO

Center for East Asian Studies Western Washington University

Center for East Asian Studies Western Washington University

3220 N.E. 80th Street

Seattle, WA 98115

Department of Biobehavioral Sciences University of Connecticut

Storrs, CT 06268

Center for East Asian Studies Western Washington University

Center for East Asian Studies Western Washington University

Far Eastern Studies

University of Saskatchewan

Center for East Asian Studies Western Washington University

Vice-President for Academic Affairs Western Washington University

Center for East Asian Studies Western Washington University

641 Houston Avenue, \#205

Takoma Park, MD 20012

5429 Anza Street

San Francisco, CA 94121 
Center for East Asian Studies

Western Washington University

Bellingham, Washington 98225

Editor

Henry G. Schwarz

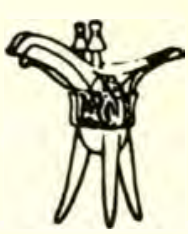

STUDIES ON EAST ASIA

(formerly Occasional Papers)

Maxims for the Well-Governed Household by Chu Yung-ch'un, translated and with a preface by Edward H. Kaplan. 1971. 10 pp. ISBN 0-914584-01-4.

Chinese Policies Towards Minorities: An Essay and Documents by Henry G. Schwarz. 1971. 200 pp., illus., bibliography. ISBN 0-914584-02-2. Out of print.

The Love of Nature: Hsü Hsia-k'o and His Early Travels by Li Chi. 1971. 134 pp., illus. ISBN 0-914584-03-0. Out of print.

Ikkȳu Söjun: A Zen Monk and His Poetry by Sonja Arntzen. 1973. x, 171 pp., illus., bibliography, index. \$1.00. ISBN 0-914584-99-5. Microfiche only.

Ten Great Years: Statistics of the Economic and Cultural Achievements of the People's Republic of China by the State Statistical Bureau, Peking (originally published in 1960). Introduction by Feng-hwa Mah. 1974. xi, 154 pp. \$4.00. ISBN $0-914584-05-7$.

Workers and Commissurs: Trade Union Policy in the People's Republic of China by Merton Don Fletcher, 1974. vi, $148 \mathrm{pp}$. , tables, bibliography. \$4.00. ISBN $0-914584-06-5$.

An Economic History of China by Chou Chin-Sheng, translated in précis and with an introduction by Edward H. Kaplan. 1974. ix, 273 pp., 26 illus., tables, glossary, index. $\$ 5.50$. ISBN $0-914584-07-3$.

Mongolian Short Stories edited and with an introductory chapter by Henry G. Schwarz. 1974. xxv, 179 pp., illus., glossary, biographical sketches. $\$ 5.00$. ISBN $0-914584-08-1$.

Han River Chulmuntogi: A Study of Early Neolithic Korea by Sarah M. Ne1son. 1975. 176 pp. 27 illus., glossary, tables, bibliography. \$5.00. ISBN $0-914584-09-\mathrm{X}$.

A Discourse on Govermment: Nakae Chömin and His Sansuijin Keirin Mondö by Margaret B. Dardess. 1977. 109 pp., 2 illus., glossary. \$4.00.

ISBN $0-914584-10-3$.

Wu Tse-t'ien and the Politics of Legitimation in T'ang China by R.W.L. Guisso. 1978. xii, 335 pp., illus., maps, bibliography, glossary, index. \$16.00. ISBN 0-914584-11-1. Hardcover only.

Bibliotheca Mongolica. Part I: Works in English, French, and German, compiled by Henry G. Schwarz. 1978. ix, 355 pp., illus., index. \$18.00.

ISBN 0-914584-12-X. Hardcover on1y. 
Studies on Mongolia: Proceedings of the First North American Conference on Mongolian Studies, edited by Henry G. Schwarz. 1979. iv, 138 pp., illus., maps. \$5.50. ISBN 0-914584-13-8.

The Korean Peasant at the Crossroads: A Study of Attitudes, by Willard D. Keim. ISBN 0-914584-14-6. About September 1979.

We accept standing orders. We will send each new title, along with an invoice, to our standing order customers. A11 other orders must be accompanied by prepayment in U.S. funds. Add the equivalent of US\$1.50 to payments in other currencies to cover bank charges.

A free examination copy of any title in print will be sent upon receipt of a firm order of at least 10 copies from a university bookstore.

There is no discount for orders of up to 9 copies per volume. We do, however, pay the book-rate charges to al1 domestic and foreign destinations. In addition, we offer the following discounts for bulk orders:

$$
\begin{array}{lll}
\text { copies per volume: } & 10-19 & 10 \% \\
& 20-29 & 20 \% \\
& 30 \text { and over } & 30 \%
\end{array}
$$

All sales are final.

Prices are subject to change without prior notice. 


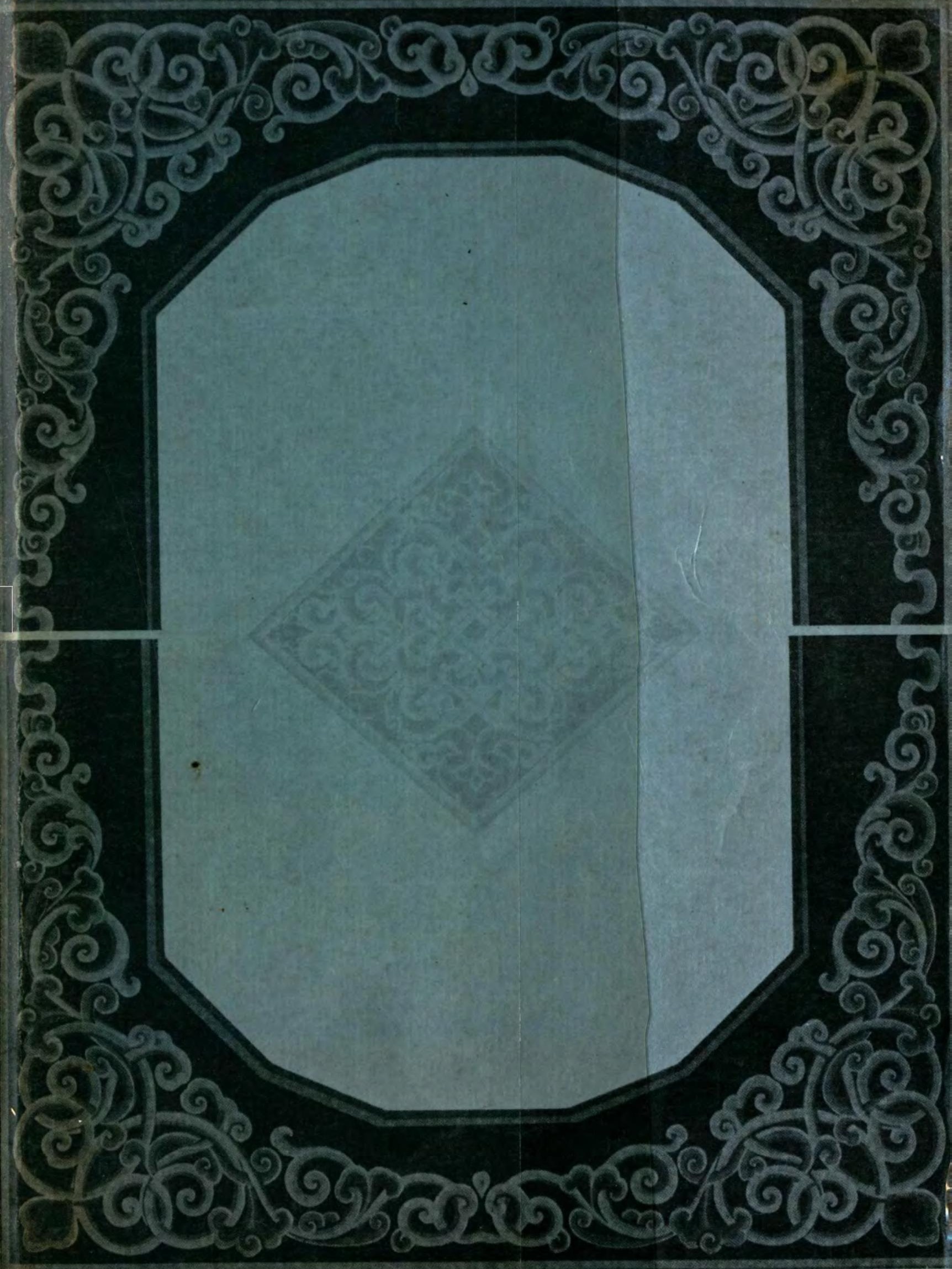

